\title{
Avaliação do sistema de tratamento de efluentes industriais através da determinação do grupo BTEX, via Cromatografia a Gás/SPME (Micro Extração em Fase Sólida).
}

Nelson Luiz Gimenez

Tese apresentada ao Programa de PósGraduação em Saúde Pública da Faculdade de Saúde Pública da Universidade de São Paulo para obtenção do título de Doutor em Saúde Pública

Área de Concentração: Saúde Ambiental Orientador: Prof. Dr. Jaim Lichtig

São Paulo

2004

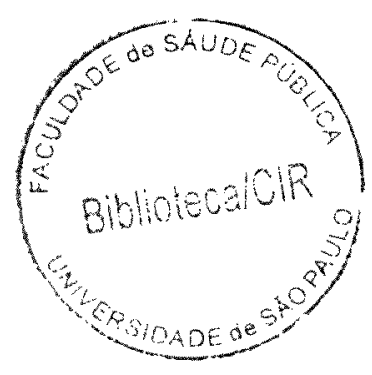


$45304 \mid 2004$ doe

Autorizo, exclusivamente para fins acadêmicos e científicos, a reprodução total ou parcial desta tese for processo fotocopiadores.

Assinatura:

Data: 12.11 .2004 


\section{AGRADECIMENTOS}

Os meus sinceros agradecimentos ao Prof. Dr. JAIM LICHTIG pela orientação prestada e pelo incentivo permanente na realização deste trabalho acadêmico.

A Akzo Nobel Ltda pelo suporte técnico, financeiro e em ceder seus laboratórios, equipamentos e materiais necessários para a realização deste trabalho.

Aos professores do curso de Pós-Graduação FSP/USP, pelos valiosos ensinamentos.

A minha família pelo carinho, apoio e compreensão para que eu chegasse até aqui.

Agradeço à todos aqueles que em algum momento desta longa jornada me incentivaram à concretização deste trabalho. 


\section{RESUMO}

O benzeno, tolueno, etil benzeno e os isômeros de xileno (grupo BTEX) são solventes aromáticos com larga utilização industrial, sendo usados na fabricação de vários produtos, como colas, diluentes, tintas vernizes, removedores e outros. A ação neurotóxica do tolueno e dos isômeros de xileno constitui risco à saúde humana a longo prazo. O risco de câncer e leucemia está associado diretamente ao benzeno. Em virtude do uso intenso desses solventes ou de sua presença na forma de contaminantes de outros produtos da indústria petroquímica, faz-se necessário realizar um controle mais efetivo dos lançamentos de águas residuárias nos corpos receptores. A avaliação do sistema de tratamento de efluentes estudado demonstrou ser ele eficiente na remoção dos compostos do grupo BTEX. Demonstrou-se também que o método analítico otimizado é válido para a determinação do grupo BTEX em baixas concentrações de 5 a $80 \mu \mathrm{g} / \mathrm{L}$, com coeficiente de variação inferior a 20. O sistema de extração, concentração, limpeza da amostra e dessorção utilizado foi a microextração em fase sólida - SPME (Solid Phase Micro-Extration) -, que, conforme se mostrou, é relativamente simples de ser usada, apresentando excelente repetibilidade dos resultados, como também alta seletividade para os compostos do grupo BTEX. Demonstrou-se ainda que o detector de ionização de chamas (DIC) é eficaz para a determinação proposta. A água obtida após o tratamento dos efluentes, mesmo não sendo utilizada diretamente para o consumo humano, apresenta níveis residuais de BTEX aceitáveis - não oferecendo risco à saúde humana -, quando comparados com os niveis máximos permitidos pelo Ministério da Saúde no Brasil. 


\section{ABSTRACT}

Benzene, toluene, ethyl benzene and xylene isomers (BTEX) are aromatic solvents extensively used in industries, and have been used in the manufacturing of many products such as adhesives, thinners, paints and clear coat among others. The neurotoxicity action of toluene and xylene isomers is a risk for human health in a long-term basis. The risk of cancer and leukemia is directly associated to the exposure to benzene. Due to the extensive use of these solvents, or as contaminant in other products in the petrochemical industry, it is necessary to have a more effective control of the dejection of residual wastewater into receptors. The evaluation of the proposed treatment system for wastewater proved to be efficient in removing the BTEX compounds. The optimization of analytical method has demonstrated to be valid for the determination of BTEX compounds at low concentration from 5 to $80 \mu \mathrm{g} / \mathrm{L}$ with variation coefficient lower than $20 \%$. The system of extraction, concentration, clean-up of sample and desorption used in this study, was the "SPME" (Solid Phase Microextration) method, which is relatively simple to be used, presenting an excellent repeatability of the results, as also high selectivity for the compounds of the BTEX group. The "FID" (Flame lonization Detector) showed to be efficient in the proposed determination. The water obtained after the wastewater treatment, which is not used directly for human consumption, showed acceptable residue levels of BTEX compounds, not offering risk for human health when compared with the maximum levels allowed by the Ministry of Health in Brazil. 


\section{INDICE}

$1 . \quad$ INTRODUÇÃO 1

1.1 Comportamento ambiental do benzeno, tolueno, etil 7 benzeno e xileno.

1.1.1 Características gerais do grupo BTEX.

1.1.1.1 Benzeno. 8

1.1.1.2 Tolueno. 9

$\begin{array}{ll}1.1 .1 .3 & \text { Etil benzeno. }\end{array}$

$\begin{array}{lll}\text { 1.1.1.4 Isômeros de xileno. } & 11\end{array}$

$1.2 \quad$ Tratamento de efluentes. 14

1.2.1 $\mathrm{O}$ pH do meio. $\quad 15$

$\begin{array}{lll}1.2 .2 & 15\end{array}$

1.2.3 Oxidação e redução. 16

$\begin{array}{lll}1.2 .4 & \text { Complexantes e quelantes. } & 16\end{array}$

$\begin{array}{lll}1.2 .5 & \text { Interações da água com outras fases. } & 17\end{array}$

$\begin{array}{lll}1.2 .6 & \text { Sedimentação. } & 18\end{array}$

$\begin{array}{lll}1.2 .7 & \text { Colóides. } & 18\end{array}$

1.2.8 A vida aquática e os microorganismos. 19

1.2.8.1 Algas. 20

1.2.8.2 Fungos. 21

1.2.8.3 Bactérias. 21

1.2.9 A biotransformação do carbono. 22

1.2.10 Biodegradação bacteriana de hidrocarbonetos. 23

1.2.11 Tratamento físico-químico. 24

1.2.12 Tratamento biológico. 25

1.2.13 Estratégia de amostragem 25

$1.3 \quad$ Cromatografia em fase gasosa. 27

1.3.1 O sistema de cromatografia a gás. 28

1.3.1.1 O gás de arraste. $\quad 28$

$\begin{array}{lll}\text { 1.3.2.2 Injetores. } & 29\end{array}$ 
1.3.1.3 Colunas. 30

1.3.2 Detectores. 30

$1.4 \quad$ Preparação de amostra ambiental. 31

1.4.1 Preparação da amostra. 31

1.4.2 Extração de compostos voláteis. 31

1.4.3 Extração por meio da fibra SPME (Microextração 32 em Fase Sólida).

1.4.3.1 Teoria da extração por SPME. 35

1.4.3.2 Coleta com a fibra 37

1.4.3.3 O processo de adsorção e dessorção. 38

1.4.3.4 Otimização dos parâmetros para uma análise 39 utilizando-se as fibras SPME.

1.4.3.5 Polaridade da fibra SPME. 39

1.4.3.6 Espessura da fibra SPME. 40

1.4.3.7 Agitação da amostra. 40

1.4.3.8 Extração por imersão $x$ headspace, adição de sal e 41 modificação do pH da solução.

1.5 Amostragem. 42

1.5.1 Técnicas de amostragem. 42

1.5.2 Escolha da embalagem a ser utilizada como 43 recipiente de coleta.

1.5.3 Acondicionamento e preservação da amostra. 44

2. OBJETIVOS 47

$2.1 \quad$ Objetivo geral. 47

$\begin{array}{lll}2.2 & \text { Objetivos especificos. } & 47\end{array}$

3. MATERIAL E MÉTODOS 48

$\begin{array}{lll}3.1 & \text { Material. } & 48\end{array}$

3.1.1 Reagentes. 48

3.1.2 Equipamentos. 49

3.1.3 Materiais de consumo 49

3.1.4 Preparação dos frascos e materiais. 50 
$3.2 \quad$ Método 51

3.2.1 Condições cromatográficas otimizadas 51

3.2.2 Preparação das soluções-padrão 52

3.2.3 Preparação da curva de calibração 52

3.2.4 Preparação das amostras 53

3.2.5 Extração dos analitos 53

3.2.6 Dessorção dos analitos no injetor 54

3.2.7 Procedimento analítico para determinação do grupo 54 BTEX em água residual

3.2.8 Validação do método 56

3.2.8.1 Seletividade 56

3.2.8.2 Linearidade 56

3.2.8.3 Limite de detecção (LOD) e limite de quantificação 56 (LOQ)

3.2.8.4 Estudo de recuperação do método analítico. 57

3.3 O sistema de tratamento em estudo. 58

3.3.1 Descrição da planta estudada 58

3.3.2 Captação do efluente. 58

3.3.3 Tratamento físico-químico. 59

3.3.3.1 Processo de coagulação e floculação. 59

3.3.3.2 O processo de sedimentação ou flotação. 62

3.3.3.3 Filtração. 65

3.3.4 Tratamento biológico. 68

3.3.4.1 Tratamento com lodo ativado (tanque de 69 equalização).

3.3.4.2 Lagoas de estabilização. 70

4. RESULTADOS E DISCUSSÕES 76

4.1 Resultados e discussões da otimização do método 76 analítico.

4.1.1 Otimização do método cromatográfico. 
4.1.2 Avaliação da sensibilidade da fibra com os 80 contaminantes presentes no ambiente do laboratório.

4.1.3 Interferência do material de vidro e da água 86 utilizada para preparação dos padrões.

4.1.4 Otimização do método via extração direta do 88 analito em água

4.1.5 Otimização do método via extração dos 92 analitos por headspace estático

4.1.5.1 Avaliação da influência da força iônica 94

4.1.5.2 Determinação do tempo ideal de extração 96

4.1.5.3 Utilização de volume reduzidos de solventes 99

4.2 Validação do método 100

4.3 Determinação do grupo BTEX no sistema de 109 tratamento de efluentes

4.4 Teste para avaliar a amostragem do tanque de 116 equalização

$4.5 \quad$ Resultado e discussão do estudo de caso. 118

$\begin{array}{lll}\text { 4.5.1 Resultados das análises dos compostos do grupo } & 118\end{array}$ BTEX após o tratamento de efluentes

4.5.2 Avaliação da biodegradadabilidade dos compostos 125 do grupo BTEX por período do ano, após o tratamento de efluentes.

4.5.3 Avaliação da biodegradabilidade dos compostos do 131 grupo BTEX durante o ciclo completo de tratamento de efluentes

4.2.2 Avaliação do risco à saúde do homem. 138

5. CONCLUSÕES 141

6. RECOMENDAÇÕES 145

$\begin{array}{ll}\text { 7. BIBLIOGRAFIA } & 146\end{array}$ 


\section{INDICE DE FIGURAS}

Figura 1 Esquema de um cromatografo a gás.

Figura 2 Esquema da técnica SPME, demonstrando-se o estágio de extração por adsorção, equilíbrio e dessorção dentro do injetor.

Figura 3 Tanque de floculação e sedimentação.

Figura 4 Amostra de água após ser coletada no reservatório de água a ser tratada.

Figura 5 Decantadores secundários.

Figura 6 Amostra da água após receber sulfato de alumínio, hidróxido de cálcio e ajuste de pH. Após 4 horas em repouso.

Figura 7 Amostras antes (esquerda) e depois (direita) do 65 tratamento físico-químico.

Figura 8 Tanque de filtração de leito contínuo com brita e areia.

Figura 9A Sistema de filtração do tipo filtro prensa.

Figura 9B Saída do sistema de filtro prensa.

Figura 10 Esquema completo do sistema de tratamento físico- 68 químico. 
Figura 11 Tanque de equalização (presença de lodo ativado).

Figura 12 Lagoa de estabilização 1 (presença de lodo ativado).

Figura 13 Lagoa de estabilização 2.

Figura 14 Sistema coletor do separador de resíduo sólido (biolodo).

Figura 15 Lagoa de estabilização 3.

Figura 16 Esquema do sistema de tratamento biológico.

Figura 17 Esquema do sistema completo de tratamento de 75 efluentes.

Figura 18 Cromatograma do Grupo BTEX na concentração de 100 $\mu \mathrm{g} / \mathrm{l}$ de cada componente, utilizado para a otimização do método analítico na coluna HP-1.

Figura 19 Cromatograma do Grupo BTEX na concentração de 100 $\mu \mathrm{g} / \mathrm{l}$ de cada componente, utilizado para a otimização do método analítico na coluna (HP-INNOWAX).

Figura 20 Cromatograma do branco da coluna, aplicando-se as 79 condições do método analítico, com a presença dos picos não identificados.

Figura 21 Cromatograma do branco da coluna, aplicando-se as 80 condições do método analítico, com a eliminação dos picos não identificados.

Figura 22 Cromatograma dos compostos adsorvidos na fibra após 
dessorção sem proteção de um septo de silicone.

Figura 23 Cromatograma do branco da fibra, protegida com nitrogênio.

Figura 24 Cromatograma do branco da fibra após uma segunda dessorção e mantido sob ambiente inerte.

Figura 25 Cromatograma do branco da fibra após permanência dentro do injetor sob um fluxo constante de 20 $\mathrm{mL} / \mathrm{minu}$ to de hidrogênio.

Figura 26 Comparação entre duas injeções do padrão de $1 \mu \mathrm{g} / \mathrm{L}$.

Figura 27 Comparação entre duas injeções do padrão de $20 \mu \mathrm{g} / \mathrm{L}$.

Figura 28 Cromatograma do padrão de concentração $1 \mu \mathrm{g} / \mathrm{L}$, primeira injeção.

Figura 29 Cromatograma do padrão de concentração $1 \mu \mathrm{g} / \mathrm{L}$, segunda injeção.

Figura 30 Equipamento para extração dos analitos por 93 "headspace".

Figura 31 Comparação entre uma extração sem e uma extração com cloreto de sódio.

Figura 32 Comparação da área total obtida $x$ tempo de extração para o benzeno, tolueno, etil benzeno, p-xileno, m-xileno e o-xileno para um padrão de $100 \mu \mathrm{g} / \mathrm{L}$. 
Figura 33 Comparação da área total obtida $\times$ temperatura de extração para o benzeno, tolueno, etil benzeno, p-xileno, $\mathrm{m}$-xileno e o-xileno utilizando-se um padrão de $100 \mu \mathrm{g} / \mathrm{L}$.

Figura 34 Curvas de calibração do benzeno (a), tolueno (b), etil 104 benzeno (c), p-xileno (d), m-xileno (e) e o-xileno (f).

Figura 35 Cromatograma do padrão de BTEX na concentração de $1 \mu \mathrm{g} / \mathrm{L}$ de cada componente.

Figura 36 Cromatograma do padrão de BTEX na concentração de 110 $5 \mu \mathrm{g} / \mathrm{L}$ de cada componente.

Figura 37 Cromatograma do padrão de BTEX na concentração de 111 $10 \mu \mathrm{g} / \mathrm{L}$ de cada componente.

Figura 38 Cromatograma do padrão de BTEX na concentração de 111 $50 \mu \mathrm{g} / \mathrm{L}$ de cada componente.

Figura 39 Cromatograma do padrão de BTEX na concentração de $100 \mu \mathrm{g} / \mathrm{L}$ de cada componente.

Figura 40 Cromatograma da análise de BTEX do tanque antes do tratamento físico-químico.

Figura 41 Cromatograma da análise de BTEX do tanque após o tratamento Físico quimico.

Figura 42 Cromatograma da análise de BTEX do tanque de 113 equalização.

Figura 43 Cromatograma da análise de BTEX da Lagoa de 114 
estabilização 1.

Figura 44 Cromatograma da análise de BTEX da Lagoa de 114 estabilização 2.

Figura 45 Cromatograma da análise de BTEX da Lagoa de 115 estabilização 3. 


\section{INDICE DE TABELAS}

Tabela 1 Produção total de BTEX por composto no ano de 2002.

Tabela 2 Principais constantes físico-químicas do grupo BTEX.

Tabela 3 Comparação da área dos picos dos compostos de interesse, após consecutivas dessorções e da diminuição da Área/Altura dos picos contaminantes.

Tabela 4 Comparação entre a repetibilidade de duas injeção do 89 padrão de $1 \mu \mathrm{g} / \mathrm{L}$ e duas injeções do padrão de $20 \mu \mathrm{g} / \mathrm{L}$, através de injeção direta.

Tabela 5 Comparação da influência de cloreto de sódio na extração dos analitos.

Tabela 6 Avaliação do tempo de extração através da comparação da altura do pico de um padrão de $100 \mu \mathrm{g} / \mathrm{L}$ com o tempo de exposição da fibra

Tabela 7 Comparação dos coeficientes de linearidade $r^{2}$ do 105 presente estudo, com dois diferentes trabalho realizados.

Tabela 8 Tabela 8 - Teste de recuperação dos analitos com um 107 padrão de $5 \mu \mathrm{g} / \mathrm{L}$ de benzeno, tolueno, etil benzeno, $\mathrm{p}$ xileno, m-xileno e o-xileno.

Tabela 9 Tabela 9 - Teste de recuperação dos analitos com um 107 padrão de $80 \mu \mathrm{g} / \mathrm{L}$ de benzeno, tolueno, etil benzeno, $\mathrm{p}$ xileno, m-xileno e o-xileno. 
Tabela 10 Teste de amostragem do tanque de equalização através de coleta de três amostras de diferentes pontos do tanque.

Tabela 11 Concentração de BTEX $(\mu \mathrm{g} / \mathrm{L})$ das amostras do tanque 119 de estocagem antes do tratamento físico químico

Tabela 12 Concentração de BTEX ( $\mu \mathrm{g} / \mathrm{L})$ das amostras do tanque 120 de estocagem após o tratamento físico químico

Tabela 13 Concentração de BTEX ( $\mu \mathrm{g} / \mathrm{L}$ ) das amostras do tanque 121 de equalização (tratamento biológico)

Tabela 14 Concentração de BTEX $(\mu \mathrm{g} / \mathrm{L})$ das amostras da lagoa de 122 estabilização 1 (tratamento biológico)

Tabela 15 Concentração de BTEX $(\mu \mathrm{g} / \mathrm{L})$ das amostras da lagoa de 123 estabilização 2 (tratamento biológico)

Tabela 16 Concentração de BTEX ( $\mu \mathrm{g} / \mathrm{L})$ das amostras da lagoa de 124 estabilização 3 (tratamento biológico)

Tabela 17 Comparação dos resultados de 12 meses do verão de2002 ao verão de 2003 do reservatório antes do tratamento físico químico.

Tabela 18 Comparação dos resultados de 12 meses do verão de 127 2002 ao verão de 2003 após o tratamento físico químico.

Tabela 19 Comparação dos resultados de 12 meses do verão de 127 2002 ao verão de 2003 do tanque de equalização. 
Tabela 20 Comparação dos resultados de 12 meses do verão de 2002 ao verão de 2003 da lagoa de estabilização 1.

Tabela 21 Comparação dos resultados de 12 meses do verão de 130 2002 ao verão de 2003 da lagoa de estabilização 2.

Tabela 22 Comparação dos resultados de 12 meses do verão de 130 2002 ao verão de 2003 da lagoa de estabilização 3.

Tabela 23 Avaliação da biodegradabilidade do grupo BTEX após o 132 tratamento de efluentes durante o verão de 2002 . Os resultados apresentados são médias de três determinações, expressas em $\mu \mathrm{g} / \mathrm{L}$

Tabela 24 Avaliação da biodegradabilidade do grupo BTEX após o tratamento de efluentes durante o verão de 2003. Os resultados apresentados são médias de oito determinações, expressas em $\mu \mathrm{g} / \mathrm{L}$

Tabela 25 Avaliação da biodegradabilidade do grupo BTEX após o 134 tratamento de efluentes durante o outono de 2003. Os resultados apresentados são médias de sete determinações, expressas em $\mu \mathrm{g} / \mathrm{L}$

Tabela 26 Avaliação da biodegradabilidade do grupo BTEX após o 135 tratamento de efluentes durante o inverno de 2003. Os resultados apresentados são médias de sete determinações, expressas em $\mu \mathrm{g} / \mathrm{L}$

Tabela 27 Avaliação da biodegradabilidade do grupo BTEX após o tratamento de efluentes durante o primavera de 2003. Os resultados apresentados são médias de seis 
determinações, expressas em $\mu \mathrm{g} / \mathrm{L}$

Tabela 28 Limites máximos permitidos para água de consumo 139 humano.

Tabela 29 Comparação dos resultados de resíduo do grupo BTEX 140 após tratamento físico-químico e biológico com os limites máximos permitidos em água potável. 


\section{INTRODUÇÃO}

Com a expansão da sociedade moderna, a utilização de materiais sintéticos, energia e espaço vem proporcionando aumento do consumo de recursos ambientais e aumento da produção de substâncias orgânicas. Muitos desses compostos são introduzidos no ambiente exclusivamente pela atividade humana (SCHWARZENBACH et al., 1993).

A utilização pelo homem de substâncias orgânicas xenobióticas no meio ambiente pode causar sérios problemas de saúde pública. Mais de 65 classes de substâncias químicas são consideradas perigosas e, dentre essas, 114 substâncias orgânicas foram designados pela EPA (Environmental Protection Agency) como poluentes prioritários. A presença dessas substâncias é atribuída à grande utilização de produtos tecnicamente inadequados e sua disposição no ambiente, podendo ocorrer a contaminação do solo e da água (KOBAYASHI e RITTMANN, 2000).

Nos últimos anos, tem ocorrido um grande número de acidentes que contaminam o ambiente, por exemplo durante a exploração do petróleo, no seu refino, transporte, nas operaçōes de armazenamento e na utilização de seus derivados nos mais diversos setores industriais e domésticos. Em muitos casos, os acidentes são provocados por inexperiência de operadores, má utilização desses produtos, desconhecimento de sua presença, descartes inadequados, como também pela falta de informações do grau de risco que muitos desses derivados ocasionam aos seres humanos e ao meio ambiente. Muitos desses acidentes acarretam contaminações de solos, águas de superfície e subterrâneas, comprometendo diretamente 0 abastecimento da água destinada ao consumo humano.

Os hidrocarbonetos monoaromáticos, benzeno, tolueno, etil benzeno, e os isômeros $\boldsymbol{o}, \boldsymbol{m}$ e $\boldsymbol{p}$ xileno, aqui denominados compostos 
BTEX, estão presentes em significativas concentrações em vários produtos, por exemplo: tintas, diluentes, removedores, contaminantes da gasolina e do diesel, entre outros, sendo também utilizados em larga escala na indústria química. Essas substâncias são consideradas perigosas ao homem, por serem depressoras do sistema nervoso central. Dentre esses compostos, o benzeno é o mais tóxico e com o menor limite aceitável quando encontrado na água e no ar.

A produção total de BTEX no Brasil em 2002 foi de $1.886 .727 \mathrm{t}$ (ABIQUIM, 2004), não incluindo a produção de BTEX carboquímico. $\mathrm{Na}$ tabela 1, descreve-se a produção individual dos compostos BTEX no Brasil no ano de 2002.

Tabela 1 - Produção total de BTEX por composto no ano de 2002

Benzeno

Tolueno

Etil Benzeno

o-Xileno

p-Xileno

Xilenos Mistos

Produção Total
813.291

316.832

421.737

78.782

101.426

154.659

1886.727

Fonte: ABIQUIM 2004.

A preocupação a respeito da poluição do solo, das águas de superfície e subterrâneas é recente e bastante restrita em nosso país. A baixa qualidade das águas superficiais e subterrâneas tem motivado uma 
atenção maior, sobretudo nas proximidades de grandes centros urbanos industrializados, por causa dos seguintes fatores (HIRATA, 1999):

- prática crescente de disposição dos efluentes domésticos e industriais sobre o solo, em larga escala, como resultado dos elevados custos de tratamento ou eliminação dos resíduos líquidos;

- aumento da produção e diversificação de produtos químicos, potencialmente contaminantes das águas;

- uso crescente de fertilizantes e pesticidas na agricultura;

- dificuldade técnica e econômica de remediação de aqüíferos contaminados.

Numa análise geral das atividades, é importante reconhecer as fontes de emissão pontual, normalmente mais simples de identificar do que as fontes dispersas. Da mesma forma, devem ser distinguidas as atividades nas quais a geração de carga contaminante é parte integral do sistema daquelas em que estão envolvidos acidentes, sobretudo considerando-se a prevenção e o controle de contaminações. Como exemplo, citam-se as freqüentes contaminações de solo e águas subterrâneas, decorrentes de vazamentos de tanques subterrâneos de gasolina em grandes cidades (HIRATA, 1999).

Os problemas de contaminação mais complexos estão relacionados com as atividades industriais, pois, dadas as altas concentrações de produtos químicos manuseados, há maior risco de contaminação ambiental por meio da eliminação de contaminantes e disposição de efluentes sem tratamento adequado. Por causa da diversidade dos processos de manufatura empregados, tornam-se maiores as dificuldades de estimar as cargas de contaminantes ambientais de forma simples e confiável. Nesse contexto geral, os principais problemas estão associados à: 
- grande variedade de atividades industriais existentes;

- diferentes niveis tecnológicos entre as indústrias;

- variação temporal desconhecida das concentrações de substâncias tóxicas nos efluentes industriais;

- grande variação no uso dos processos de tratamento para efluentes $e$ às incertezas sobre a efetividade na remoção de contaminantes potencialmente perigosos para o ambiente;

- falta de controle efetivo nas análises dos efluentes e de resíduos diversos, incluindo metais pesados e organosintéticos;

- falta de informações adequadas sobre as caracteristicas dos efluentes e resíduos industriais.

Num contexto geral, as empresas manuseiam grandes quantidades de substâncias quimicas, sendo assim podem gerar vários tipos de cargas contaminantes associadas às matérias-primas utilizadas nos processos de fabricação de seus produtos. Normalmente certas quantidades de matérias-primas estão presentes nos efluentes, podendo não ser totalmente eliminadas e serem disponibilizadas nos corpos receptores, por causa dos inadequados sistemas de tratamento de efluentes (HIRATA, 1999).

Mesmo utilizando a melhor tecnologia possível para tratamento de efluentes, as empresas não estão livres da possibilidade de contaminar o solo e as águas de superfície ou subterrâneas, pois durante o manuseio, armazenamento e transporte de substâncias tóxicas podem ser geradas cargas poluentes importantes, em caso de acidentes ou quando os resíduos gerados não são eliminados adequadamente nos sistemas de tratamento de efluentes (HIRATA, 1992).

Por causa de vários fatores ambientais, há maior dificuldade de degradação das substâncias xenobióticas nos tratamentos de efluentes. A 
escolha do grupo BTEX para este estudo está fundamentada na baixa biodegradabilidade ambiental desses compostos e no seu maior tempo de persistência no sistema de tratamento em relação a outras substâncias químicas, possivelmente por serem disponibilizados nos corpos receptores em decorrência do fato de não serem biodegradados.

Os compostos do grupo BTEX classificam-se como depressores do sistema nervoso central, e a exposição a esses compostos a longo prazo pode causar risco à saúde humana. A ação neurotóxica associase à exposição ao tolueno e xileno, e o risco de câncer, ao benzeno (ATSDR, 1994, 1995, 1997; POISIDEX 1998 e CASARETT AND DOLL's, 1995). Dessa forma, é importante que a eficiência do tratamento de efluentes seja efetiva para a redução dos resíduos do grupo BTEX na água residual.

A atual legislação brasileira não estabelece parâmetros de lançamento para o grupo BTEX no corpo receptor, ou seja, não estão estabelecidos limites residuais de BTEX em águas oriundas de efluentes industriais. A resolução número 20 do CONAMA, de 18/06/1986, indica parâmetros gerais referentes aos níveis máximos aceitáveis de compostos orgânicos em água. A lei estadual número 997/SP e o decreto estadual número $8.468 / \mathrm{SP}$ também não estabelecem parâmetros para lançamento de BTEX em águas residuárias. O Ministério da Saúde, por meio da portaria número 1.469 , de 29/12/2000, indica quais são os limites máximos de residuos de BTEX em água potável. Sendo assim, esses serão os limites de referência para comparação com os niveis de resíduos encontrados após o tratamento de efluentes.

É necessária a otimização de um método analítico adequado para a determinação dos níveis de resíduos dos compostos do grupo BTEX em amostras de águas residuais provenientes do sistema de tratamento de efluentes. Normalmente a concentração dos compostos do grupo BTEX está muito baixa sendo necessário extrair os compostos e concentrá-los, como 
também utilizar uma técnica analítica adequada para que se atinja a sensibilidade desejada.

A EPA (2004) criou um programa chamado Green Chemistry, que tem por objetivo o desenvolvimento de produtos ou processos químicos que reduzam ou eliminem o uso ou a geração de substâncias perigosas. Dessa forma, é importante levar em consideração a utilização de métodos analíticos que atendam aos princípios do Green Chemistry.

O sistema de cromatografia a gás é muito bem difundido e conta com várias técnicas para extração e concentração dos analitos. Muitas vezes se utilizam técnicas com injeções diretas a partir do sistema de extração e concentração, por exemplo o sistema purge and trap e headspace, aplicadas diretamente ao cromatógrafo. Entretanto, essas técnicas são caras e não são muito difundidas ou introduzidas com facilidade nos laboratórios.

Entre as técnicas de extração e concentração existentes, escolhemos a técnica SPME (Solid Phase Micro-Extration), que consiste na combinação de técnicas simultâneas de amostragem, extração, préconcentração e introdução dos analitos da amostra diretamente no sistema cromatográfico (SUPELCO, 1998). A técnica SPME apresenta facilidade em seu manuseio e oferece rapidez. Outro ponto importante que devemos mencionar é o fato de o custo dessa técnica ser muito inferior ao das técnicas convencionais, diminuindo-se também o custo por amostra.

Por causa do tipo de matriz a ser analisada, é necessária a otimização de um método de análise para o BTEX que seja simples, sensivel, preciso e exato, como também aplicável para as amostras do sistema de tratamento de efluentes em estudo. Para o método ser aplicado amplamente, é necessário validá-lo nas condições adotadas para a análise. 


\subsection{Comportamento ambiental do benzeno, tolueno, etil benzeno e xilenos}

Estudos realizados por agências e institutos internacionais vêm dando ênfase para os temas que avaliam a exposição de crianças, adolescentes, mulheres em gestação e dos trabalhadores das indústrias químicas às substâncias químicas tóxicas. Os maiores riscos de exposiçōes a essas substâncias podem estar ligados às moradias próximas de depósitos de resíduos tóxicos, indústrias químicas, plantas de tratamento de efluentes tóxicos não-equalizadas e a vazamentos acidentais durante o transporte de cargas perigosas (ATSDR, 2001).

Conhecer os locais contaminados com substâncias tóxicas é muito importante para prevenir a exposição a esses agentes que podem causar dano à saúde humana e ao ambiente em geral. A exposição pode ser pela respiração, ingestão de alimentos e de água contaminada ou pelo contato com a pele. Após a exposição a uma substância tóxica, muitos fatores poderão determinar o risco de danos à saúde. Esses fatores incluem o tempo de exposição à concentração ambiental, o modo pelo qual se deu o contato com o agente tóxico, como também a toxicidade da substância.

\subsubsection{Características gerais do grupo BTEX}

O grupo BTEX compõe-se de substâncias voláteis obtidas da destilação do petróleo, do carvão e da pirólise de alguns compostos. Além de serem encontradas como substâncias puras e isoladas, podem estar presentes como contaminantes de vários derivados do petróleo, por exemplo: combustiveis, aguarrás, querosene, solvente de borracha, entre outros. Há ainda outras fontes naturais do grupo BTEX, tais como: óleo cru, presente na queima de florestas, tabaco (fumaça de cigarro), entre outros. 


\subsubsection{Benzeno}

O benzeno, também conhecido pelo nome comercial de benzol, é um líquido incolor com odor adocicado, muito inflamável e de evaporação rápida, sendo pouco solúvel em água (Tabela 1). $O$ benzeno é largamente utilizado para a fabricação de várias substâncias químicas, por exemplo: estireno, cumeno, ciclohexano, entre outros produtos. Pode ainda ser empregado na fabricação de alguns detergentes, borrachas, lubrificantes, secantes e na síntese de pesticidas.

O benzeno foi detectado entre 50 e $60 \%$ das amostras de água potável analisada em mais de 30 estações de tratamento de água potável do Canadá. A concentração de benzeno encontrada nas estações esteve entre 1 e $3 \mu \mathrm{g} / \mathrm{L}$, com um valor máximo encontrado de $48 \mu \mathrm{g} / \mathrm{L}$. A agência federal de água potável dos Estados Unidos estima que aproximadamente 1,3\% de todos os aqüiferos subterrâneos podem estar contaminados por benzeno na concentração média de $0,5 \mu \mathrm{g} / \mathrm{L}$ e podendo atingir, em alguns casos, níveis próximos de $80 \mu \mathrm{g} / \mathrm{L}$ (WHO, 1996). Foram encontrados niveis de $170 \mu \mathrm{g} / \mathrm{L}$ de benzeno em estações de tratamento de efluentes de indústrias químicas e de 5 a $20 \mathrm{ng} / \mathrm{L}$ na água do mar próximo à área costeira (WHO, 1996).

Descarte e disposições incorretas de produtos químicos contendo benzeno, bem como vazamentos de gasolina de tanques subterrâneos, são as principais fontes de contaminação do solo e de águas subterrâneas. $O$ benzeno presente no ar pode ser carregado para o solo por meio da chuva e neve. Uma vez no solo, pode chegar à água de superfície e ser carregado para o subsolo (ATSDR, 1997).

No ar, o benzeno pode reagir com outras substâncias químicas, quebrando-se, em poucos dias, a molécula em substâncias menos tóxicas. Ele pode reagir com radicais hidroxilas com tempo de meia-vida de cinco dias (EPA, 1987). O benzeno no solo ou na água degrada-se 
lentamente e pode ser metabolizado principalmente por microorganismos, plantas e animais (ATSDR, 1997).

\subsubsection{Tolueno}

O tolueno, também conhecido pelo nome comercial de toluol, é um líquido incolor com odor distinto, é inflamável e pode evaporar rapidamente. É pouco solúvel em água (Tabela 1). $O$ tolueno é muito utilizado na fabricação de tintas, diluentes para tintas, polidores, lacas, adesivos, borrachas, tintas para impressão e manufatura de couro.

O tolueno é o hidrocarboneto aromático com maior prevalência na atmosfera, na faixa de 0,53 a $200 \mu \mathrm{g} / \mathrm{m}^{3}$ (EPA, 1983). A concentração observada em áreas povoadas está na faixa de 5 a $25 \mu \mathrm{g} / \mathrm{m}^{3}$ e em áreas remotas abaixo de $0,18 \mu \mathrm{g} / \mathrm{m}^{3}$ (EPA, 1988 e ATSDR, 1994).

A contaminação do ar interno de prédios foi estimada, em média, em $20 \mu \mathrm{g} / \mathrm{m}^{3}$ de tolueno, em decorrência do hábito de fumar (80 a $160 \mu \mathrm{g}$ por cigarro) (HAJIMIRAGLIA et al., 1989). Na Alemanha foi encontrado tolueno na água de chuva, entre 0,13 e $0,70 \mu \mathrm{g} / \mathrm{L}$, e na Holanda um valor médio de $0,04 \mu \mathrm{g} / \mathrm{L}$ (WHO, 1996). Na água de rios dos Estados Unidos foram observadas concentrações entre 1 e $5 \mu \mathrm{g} / \mathrm{L}$. Em água subterrânea foram encontradas concentrações na faixa de 0,2 a $1,1 \mathrm{mg} / \mathrm{L}$ (EPA, 1983). A média de exposição de tolueno calculada por pessoa é de aproximadamente $300 \mu \mathrm{g} / \mathrm{m}^{3}$ por dia, por causa principalmente do hábito de fumar (ATSDR, 1994).

Em aproximadamente $1 \%$ da água subterrânea utilizada como fonte de água para consumo público nos Estados Unidos foram observados niveis de tolueno acima de $0,5 \mu \mathrm{g} / \mathrm{L}$. Em estudos realizados em 30 estações 
de tratamento de água no Canadá, foi observada uma média de $2 \mu \mathrm{g} / \mathrm{L}$ de tolueno livre (WHO, 1996).

O tolueno, quando presente no solo ou em águas superficiais, pode ser metabolizado principalmente pela ação de microorganismos, mas, quando dissolvido em água subterrânea, sua biodegradação fica comprometida em decorrência da falta de oxigênio. No ar, o tolueno reage com o oxigênio formando benzaldeído e cresóis, substâncias também tóxicas para seres humanos e animais. O tolueno é removido rapidamente pela reação com o oxigênio atômico, peróxidos ou radicais hidroxilas e ozônio (WHO, 1996).

A transferência do tolueno para a água de consumo humano é relativamente baixa, em virtude de sua baixa solubilidade na água, mas ele é facilmente solúvel em matéria orgânica do solo e, dessa forma, pode contaminar águas subterrâneas e de consumo doméstico (WILSON et al., 1981).

O tolueno pode ser encontrado em tecidos de peixes, moluscos, mariscos, plantas e animais que vivem em areas contaminadas, mas na maioria dos animais são encontradas baixas concentrações por causa de sua metabolização e excreção (ATSDR, 1994).

\subsubsection{Etil benzeno}

O etil benzeno é um líquido incolor com cheiro adocicado que lembra gasolina, é inflamável e pode evaporar rapidamente à temperatura ambiente. É pouco solúvel em água (Tabela 1). $O$ etil benzeno é muito utilizado na fabricação de tintas em geral. Na indústria química é utilizado na fabricação de estireno, acetofenona, acetato de celulose, dietil benzeno, etil antraquinona, óxido de propileno e metil benzil álcool, entre outros. 
O etil benzeno tem sido detectado no ar em concentrações abaixo de $2 \mu \mathrm{g} / \mathrm{m}^{3}$ nas cidades e menos de $0,1 \mu \mathrm{g} / \mathrm{m}^{3}$ nas zonas rurais. O etil benzeno foi detectado no ar exalado de fumantes, na concentração de 3,1 a $4,5 \mu \mathrm{g} / \mathrm{m}^{3}$ (CLAYTON et al., 1994).

Observou-se a presença de etil benzeno em rios da Espanha na concentração de $15 \mu \mathrm{g} / \mathrm{L}$ e em águas subterrâneas entre 0,03 e 0,3 mg/L. Em estudos realizados em 30 estações de tratamento de água no Canadá, foi observada uma média de $1 \mathrm{ng} / \mathrm{L}$ de etil benzeno livre (WHO, 1996). O etil benzeno é facilmente encontrado na forma de vapor no ar, por evaporar rapidamente da superfície contaminada, seja ela solo ou água. O tempo de residência do etil benzeno no ar não costuma ultrapassar três dias, por causa da foto decomposição. A reação com radicais hidroxilas proporciona uma meia-vida de um dia (WHO, 1996).

No solo, o etil benzeno é metabolizado por bactérias e, quando combinado com partículas do solo, pode arrastar-se e contaminar águas subterrâneas. A meia-vida para degradação aeróbica é de 24,2 dias (WHO, 1996).

\subsubsection{Xilenos}

Os xilenos, também conhecidos pelo nome comercial de Xilol ou pelo nome químico individual de orto, meta e para dimetil benzeno, são liquidos incolores com odor adocicado, inflamáveis e podem evaporar lentamente, sendo também pouco solúveis em água (Tabela 1). Os xilenos são muito utilizados como solventes de tintas de impressão, borrachas e na indústria de couro. São utilizados na indústria de base para fabricação de matérias-primas para polímeros, ácidos, aditivos e fibras sintéticas. 
Foram encontradas fontes de água subterrâneas contaminadas com xilenos no ponto de emissão na faixa de 0,3 a $5,4 \mathrm{mg} / \mathrm{L}$ - valores abaixo de $0,1 \mu \mathrm{g} / \mathrm{L}$ são considerados niveis de baixa contaminação para águas subterrâneas. Nos Estados Unidos foram encontrados valores acima de 2,5 $\mu \mathrm{g} / \mathrm{L}$ (EPA, 1983). A presença de xilenos nos niveis de $0,5 \mu \mathrm{g} / \mathrm{L}$ com valores máximos de $5,2 \mu \mathrm{g} / \mathrm{L}$ foi observada em aproximadamente $3 \%$ da água subterrânea utilizada para água de consumo e $6 \%$ de toda a água de superficie utilizada para abastecimento público nos Estados Unidos (EPA, 1988). Foi detectada a presença de $m$-xileno na água potável para consumo na concentração de $1 \mu \mathrm{g} / \mathrm{L}$ em sete das 30 estações de tratamento de águas de abastecimento público no Canadá (WHO, 1996).

Os xilenos, em relação aos outros compostos do grupo BTEX, têm menor taxa de evaporação, conseqüentemente podem permanecer mais tempo na superfície do solo e na água. Em virtude dessa característica, podem permanecer no solo, superficies de águas (rios, córregos, canais, lagos) ou fontes subterrâneas por vários meses. Uma vez evaporados, os xilenos podem permanecer no ar por vários meses até sofrer degradação pela luz e transformarem-se em substâncias menos tóxicas. Os xilenos presentes no solo e na água podem ser metabolizados lentamente por microorganismos presentes no ambiente. Pequenas quantidades podem ser encontradas em peixes, plantas e pássaros. Ainda não se conhece exatamente quanto tempo os xilenos podem permanecer nas águas superficiais (lagos e rios) e subterrâneas, pois isso dependerá do tempo de evaporação e da metabolização por microorganismos (ATSDR, 1995).

Observou-se que os xilenos permanecem por meses e até anos em águas subterrâneas, em condições aeróbicas e apresentando um tempo de meia-vida de 24 dias, podendo chegar até a 161 dias WHO, 1996). Em solo úmido podem permanecer por muito mais tempo do que em solo seco (ATSDR, 1995). 
Tabela 2 - Principais constantes Físico-Químicas do grupo BTEX.

\begin{tabular}{|c|c|c|c|c|c|c|}
\hline Propriedades & Benzeno & Tolueno & $\begin{array}{c}\text { Etil } \\
\text { Benzeno }\end{array}$ & p-Xileno & m-Xileno & o-Xileno \\
\hline CAS-Number & $71-43-2$ & $108-88-3$ & $100-41-4$ & $106-42-3$ & $108-38-3$ & $95-47-6$ \\
\hline Fórmula & $\mathrm{C} 6 \mathrm{H} 6$ & $\mathrm{C} 7 \mathrm{H} 8$ & $\mathrm{C} 8 \mathrm{H} 10$ & C8H10 & $\mathrm{C8H} 10$ & $\mathrm{C} 8 \mathrm{H} 10$ \\
\hline $\begin{array}{c}\text { Massa } \\
\text { molecular }\end{array}$ & 78,1 & 92,13 & 106,16 & 106,16 & 106,16 & 106,16 \\
\hline $\begin{array}{l}\text { Ponto de fusåo } \\
\left({ }^{\circ} \mathrm{C}\right)\end{array}$ & $+5,5$ & -95 & - 94,4 & $+13,2$ & $-47,0$ & -25 \\
\hline $\begin{array}{c}\text { Densidade } \\
\left(\mathrm{g} / \mathrm{cm}^{3}\right)\end{array}$ & 0,879 & 0,866 & 0,867 & 0,861 & 0,867 & 0,881 \\
\hline $\begin{array}{c}\text { Ponto de } \\
\text { ebuliçăo }\left({ }^{\circ} \mathrm{C}\right)\end{array}$ & 80,1 & 110,8 & 136,2 & 138,5 & 139,3 & 144 \\
\hline $\begin{array}{c}\text { Solubllidade em } \\
\text { água (mg/l a } 25 \\
\left.{ }^{\circ} \mathrm{C}\right)\end{array}$ & $1,7 \times 10^{+3}$ & $5,26 \times 10^{+2}$ & $1,69 \times 10^{+2}$ & $1,98 \times 10^{+2}$ & $1,6 \times 10^{+2}$ & $1,78 \times 10^{+2}$ \\
\hline $\begin{array}{l}\text { Coeficiente de } \\
\text { partição } \\
\text { octanolágua }\end{array}$ & 2,13 & 2,73 & 3,15 & 3,15 & 3,2 & 3,12 \\
\hline $\begin{array}{l}\text { Densidade do } \\
\text { vapor } A r=1\end{array}$ & 2,8 & 3,1 & 3,66 & 3,70 & 3,70 & 3,70 \\
\hline $\begin{array}{c}\text { Viscosidade } \\
\text { mPas.s }\end{array}$ & 0,604 & 0,560 & 0,678 & 0,648 & 0,620 & 0,760 \\
\hline $\begin{array}{l}\text { Pressåo de } \\
\text { vapor }\end{array}$ & $\begin{array}{c}13,3 \mathrm{Kpa} \mathrm{a} \\
26,1^{\circ} \mathrm{C}\end{array}$ & $\begin{array}{c}3,78 \mathrm{Kpa} \mathrm{a} \\
25^{\circ} \mathrm{C}\end{array}$ & $\begin{array}{c}0,933 \mathrm{Kpa} \mathrm{a} \\
20^{\circ} \mathrm{C}\end{array}$ & $\begin{array}{c}1,17 \mathrm{Kpa} \mathrm{a} \\
25^{\circ} \mathrm{C}\end{array}$ & $\begin{array}{c}1,11 \mathrm{Kpa} \mathrm{a} \\
25^{\circ} \mathrm{C}\end{array}$ & $\begin{array}{c}0,906 \mathrm{Kpa} \mathrm{a} \\
25^{\circ} \mathrm{C}\end{array}$ \\
\hline
\end{tabular}

Fonte: CRC-Handbook of Chemistry and Physics 2003-2004. 


\subsection{Tratamento de Efluentes}

Os sistemas de tratamento de esgotos (efluentes) foram, inicialmente, concebidos como resposta à preocupação com a descarga de efluentes no meio ambiente e com seus efeitos negativos. Nessas condições, os objetivos primários do tratamento eram a remoção de sólidos em suspensão e flotáveis, a remoção de compostos orgânicos biodegradáveis e a remoção de organismos patogênicos (HESPANHOL, 2002).

Para compreendermos os sistemas de tratamento de esgotos, efluentes e remediação de solo e aqüíferos, temos de estudar vários fenômenos da química e da biologia ambiental, que compreendem não só a análise dos fatores físico-químicos, mas também o reconhecimento da influência que cada microorganismo tem sobre o processo de autodepuração natural. Dessa forma, podemos extrapolar todo o conhecimento adquirido junto à natureza e aplicá-lo diretamente nos sistemas de tratamento. Basicamente os sistemas de tratamento estão fundamentados no conhecimento da ação microbiológica sobre diversos substratos (MANAHAN, 1993).

Para isso, cada vez mais estudam-se os sistemas de tratamento de esgoto e efluentes propondo-se novas alternativas, que irão melhorar a remoção de substâncias tóxicas. Quando analisamos um sistema, devemos considerar principalmente quais são os compostos tóxicos em questão e qual é a melhor forma de removê-los do efluente, como também, após sua remoção, qual o tipo de destino final que melhor se adapte às suas condições e evite contaminações futuras.

Para que se compreendam melhor todas as interfaces desses processos de tratamento, apresentamos uma breve introdução sobre todos 
os fenômenos associados às transformações biogeoquímicas no ambiente e que afetam o processo de tratamento de efluentes.

\subsection{1 $\mathrm{O} \mathrm{pH}$ do meio}

A alteração do pH dos sistemas de tratamento está ligada diretamente à quantidade de íons $\mathrm{H}^{+}$e $\mathrm{OH}^{-}$disponiveis no meio e de sais com características de oxiácidos ou oxibásicos. Dependendo das quantidades dessas espécies quimicas, a água poderá adquirir caráter alcalino ou ácido. $O$ aumento da alcalinidade nos sistemas de tratamento de esgoto e efluentes pode causar alterações na vida aquática e no crescimento de microorganismos.

Tanto a água de origem natural como a de efluentes industriais com elevado indice de alcalinidade podem ser tratadas com sulfato de alumínio hidratado como coagulante. $\mathrm{O}$ ion de alumínio $\mathrm{Al}\left(\mathrm{H}_{2} \mathrm{O}\right)_{6}{ }^{3+}$ é um íon com caracteristica de ácido fraco e, quando adicionado à água, reage com as bases livres, precipitando um gel de hidróxido de alumínio.

A acidez é geralmente provocada pela presença dos ácidos livres, tais como: $\mathrm{H}_{2} \mathrm{PO}_{4}^{-}, \mathrm{CO}_{2}, \mathrm{H}_{2} \mathrm{~S}$, ácidos graxos, ácido nítrico e alguns ions metálicos, particularmente o ion $\mathrm{Fe}^{3+}$. Algumas vezes temos alguma dificuldade em determinar a acidez exata em virtude de algumas substâncias serem voláteis, tais como o $\mathrm{CO}_{2}$ e $\circ \mathrm{H}_{2} \mathrm{~S}$.

\subsection{2 Íns Metálicos}

Os ions metálicos presentes na água, nos esgotos e efluentes são representados por $\mathrm{M}^{\mathrm{n}+}$, por exemplo $\circ \mathrm{Mg}^{2+}$, e não podem existir 
separadamente, ou seja, estão combinados com algumas moléculas de água na forma de ion metálico hidratado $\mathrm{M}\left(\mathrm{H}_{2} \mathrm{O}\right)_{x}{ }^{\mathrm{n+}}$.

Nos tratamentos de efluentes industriais se utiliza um processo de forma a se obterem compostos insolúveis em água, para a remoção dos metais por precipitação, que culmina com a formação de compostos à base de carbonatos insolúveis.

\subsubsection{Oxidação e redução}

As reações de oxidação e redução em água envolvem a transferência de elétrons entre as substâncias químicas. Na água natural, em esgotos, efluentes industriais e no solo, são reaçōes provocadas significativamente por bactérias.

A reação química entre as substâncias depende diretamente da atividade dos elétrons na solução. Quando essa atividade é relativamente alta, as substâncias químicas (incluindo a água) tendem a receber elétrons, sofrendo redução. Quando a atividade é relativamente baixa, o meio é oxidante e, dessa maneira, as substâncias podem ser oxidadas com a perda de elétrons. A tendência relativa à oxidação e redução é baseada em um potencial de um sistema redox, que é relativamente mais positivo no meio oxidante e negativo no meio redutor.

\subsubsection{Complexantes e quelantes}

Em geral, os complexantes e quelantes atuam sobre os ions metálicos, formando substâncias mais estáveis na água. Os metais, por sua vez, contribuem com um par de elétrons para formar essas novas substâncias, por meio da formação de uma ou mais ligações covalentes 
coordenadas. Essa nova substância é formada por um ion metálico central rodeado por átomos ou moléculas, formando um complexo ou composto de coordenação.

A presença de complexantes diminui a eficiência na remoção de metais pesados; estes, por sua vez, só são reduzidos com um tratamento biológico com lodo ativado. Normalmente o tratamento convencional apresenta dificuldades para eliminar substâncias quimicas com capacidade de formar complexos estáveis e solúveis. Nesse contexto podemos citar os organometálicos como sendo substâncias com alto risco para o meio ambiente, como também pela dificuldade de serem eliminados no tratamento químico ou biológico.

\subsubsection{Interaçōes da água com outras fases}

Muitos residuos de compostos químicos perigosos formam emulsões com água na forma de pequenas partículas em suspensão, e alguns desses resíduos são depositados por sedimentação ou oclusão durante o processo de floculação no sistema de tratamento.

Compostos orgânicos, tais como hidrocarbonetos líquidos, podem estar presentes na superficie da água. A exposição à luz solar pode provocar algumas reaçōes fotoquímicas sobre as substâncias e propiciar a sua decomposição química. Também podem ocorrer outros processos bioquimicos de biodegradação dos resíduos orgânicos, por meio das células de bactérias e fungos. Resíduos sólidos aumentam a turbidez da água e são eliminados por meio de processos físico-químicos. 


\subsubsection{Sedimentação}

Por meio de reações quimicas e bioquimicas, os sedimentos podem fornecer ao meio uma variedade muito grande de substâncias. A partir dos sedimentos e da matéria orgânica, algumas bactérias anaeróbicas produzem gás metano e podem transformar o mercúrio inorgânico, praticamente insolúvel ( $\mathrm{HgS}$ ) e inofensivo, em uma espécie química solúvel e muito tóxica para o ambiente, o $\mathrm{Hg}\left(\mathrm{CH}_{3}\right)_{2}$. Alguns sais de metais pesados sedimentados nos esgotos e efluentes podem sofrer processos bioquímicos e serem liberados no meio como substâncias solúveis em água.

\subsubsection{Colóides}

Uma das mais importantes interações entre as substâncias químicas dissolvidas em soluções aquosas ou em outras fases ocorre com partículas coloidais. Essas particulas apresentam tamanho aproximado de 0,001 a $1 \mu \mathrm{m}$ de diâmetro. Os colóides têm grande influência sobre a química aquática porque são partículas extremamente pequenas, com grande volume superficial, podendo permanecer em suspensão por longos períodos.

Medidas especiais devem ser tomadas para remover as partículas coloidais da água, por meio de tratamentos físico-químicos, como, por exemplo, coagulação ou flotação, para posterior remoção dos resíduos por sedimentação e filtração. A desestabilização química dos colóides é obtida por meio da adição de substâncias químicas coagulantes que provocam a agregação dos colóides, formando partículas maiores que tendem a precipitar-se. Sais de $\mathrm{Fe}$ (III) e de $\mathrm{Al}(\mathrm{III})$ e alguns polimeros orgânicos são muito utilizados para a coagulação (ØDEGAARD, 1979). 


\subsubsection{A vida aquática e os microorganismos}

Os microorganismos aquáticos no ecossistema podem ser classificados em autotróficos ou heterotróficos. Os microorganismos autotróficos utilizam a luz solar como fonte de energia para transformar os elementos mais simples - ou seja, material inorgânico -, transformando-os em complexas moléculas, vitais para a vida dos microorganismos vivos.

Os microorganismos heterotróficos utilizam as substâncias produzidas pelos autotróficos como energia e matéria-prima para a síntese de sua própria biomassa. Os organismos decompositores consistem principalmente em bactérias e fungos, que quebram os materiais de origem biológica, transformando-os em simples compostos, originalmente fixados pelos organismos autotróficos.

Os microorganismos compõem diversos grupos de organismos, os quais geralmente são capazes de existir como uma única célula e só podem ser observados por meio de um microscópio. As bactérias e fungos constituem organismos microscópicos unicelulares, mas são muito importantes, porque participam de muitas reações químicas, conforme abaixo:

- As algas fotossintéticas têm a habilidade de transformar carbono inorgânico em matéria orgânica;

- As bactérias podem promover reações químicas em ambiente aquático;

- As bactérias mineralizam material elementar, especialmente nitrogênio e fósforo, que são a chave do ciclo de nutrientes;

- Muitas bactérias aquáticas são responsáveis por biotransformar os poluentes presentes no ambiente. 
Do ponto de vista da química ambiental, uma pequena quantidade de microorganismos, mas particularmente significativa, possibilita rapidamente a transformação de nutrientes em metabolitos. Isso, combinado com o crescimento da população de microorganismos favorece a rápida biodegradação da matéria orgânica tóxica (MANAHAN, 1993).

A principal função dos microorganismos é proporcionar um vasto número de processos bioquímicos que ocorrem na água e no solo. As principais reações químicas ocorrem no próprio local, ou seja, na água ou no solo, particularmente envolvendo os processos de oxidação e redução, que ocorrem por intermédio das bactérias. As algas são produtoras biológicas de biomassa na água e os microorganismos são também responsáveis pela formação de sedimentos e depósitos minerais, como também pelo tratamento secundário de esgotos e efluentes industriais.

\subsubsection{Algas}

Para o propósito desta discussão, as algas podem ser consideradas como vegetais microscópicos que transformam nutrientes inorgânicos em matéria orgânica pela fotossíntese.

Alguns tipos de algas podem metabolizar algumas substâncias químicas cloradas, por meio da dehalogenação por redução. Um exemplo de redução biológica de dehalogenação muito bem documentado foi descrito para pesticidas e hidrocarbonetos halogenados. Estes são casos de interesse particular de remoção de átomos de cloro por redução que ocorrem em algas. Nas algas, o processo de decloração pode ser monoenzimático por transformação fotoquímica. Essa transformação ocorre diretamente pela absorção de energia luminosa por compostos fotossensiveis, que transferem os elétrons do reagente para as moléculas do inseticida (KOBAYASHI e RITTMANN, 2000). 
KOBAYASHI e RITTIMANN (2000) citam em seu trabalho algumas algas que podem metabolizar poluentes ambientais, tais como: a Oscilatoria sp. (bifenilas, naftaleno e chlordimefor), Anacystis niduans (Dieldrin), Chlorella vulgaris (Lindane), entre outras.

\subsubsection{Fungos}

Os fungos são organismos não-fotossintéticos que se manifestam freqüentemente na forma filamentosa. Os fungos são aeróbicos, ou seja, necessitam de oxigênio para seu desenvolvimento e geralmente toleram mais ácidos e altas concentrações de metais pesados do que as bactérias.

Apesar de os fungos não crescerem bem em água, eles têm um importante papel na decomposição da matéria orgânica presente na água natural ou de efluentes, porque são responsáveis pela decomposição de muitos produtos, por exemplo a quebra de celulose da madeira e de plantas. As células dos fungos secretam enzimas extracelulares denominadas exoenzimas, que realizam a biodegradação da celulose. Para - meio ambiente, a decomposição realizada pelos fungos favorece a eliminação de restos de plantas e matéria orgânica particulada.

\subsubsection{Bactérias}

As bactérias são microorganismos procariontes unicelulares com diferentes formas, tais como: bastão (bacilus), esferas (coccus) e espirais (víbrios, espirilas, espiroquetas); esses organismos são muito importantes para a química do meio ambiente. Além da forma específica, as bactérias têm características importantes para sua sobrevivência, incluem membrana celular semi-rígida e flagelo para locomoção. Por serem 
unicelulares, multiplicam-se por meio da fissão da célula-mãe em duas outras células-filhas idênticas à célula-mãe (VOZNAYA, 1981).

As bactérias necessitam obter energia por meio de reações químicas com matéria orgânica e, como subprodutos de sua reaçăo, são excretadas substâncias químicas chamadas metabolitos. Em virtude dessa característica, podem participar de várias reações biogeoquímicas elementares na transição e no ciclo da água e do solo (MANAHAN, 1993).

As bactérias heterotróficas são muito mais comuns no ambiente do que as bactérias autotróficas. Esses microorganismos são responsáveis pela quebra da matéria orgânica poluente na água e nos processos de tratamento biológico de efluentes industriais e esgotos (VOZNAYA, 1981).

As bactérias aeróbicas são aquelas que necessitam de oxigênio e um par de elétrons receptor para crescerem. Bactérias anaeróbicas sobrevivem em locais com isenção de oxigênio e usam substâncias como ions nitrato e sulfato como substituto do oxigênio. Freqüentemente o oxigênio é um pouco tóxico para bactérias anaeróbicas. Normalmente a maior atividade dessas bactérias se dá nas grandes profundidades do sistema de tratamento. Bactérias facultativas representam a terceira classe de bactérias que utilizam pouco oxigênio, quando disponivel, e que utilizam outras substâncias como receptores de elétrons (oxidantes), quando o oxigênio não está disponivel (MANAHAN, 1993).

\subsubsection{A biotransformação do carbono}

O carbono é encontrado na atmosfera em grande quantidade, como minerais, particularmente na forma de carbonato de cálcio e magnésio. 
Outra fração importante é encontrada no petróleo e gás natural, no carvão e na lignita.

A principal forma de fixação do gás carbônico livre da atmosfera é realizada pelo processo de fotossíntese. Outra forma de fixação está relacionada a mudanças de $\mathrm{pH}$ da água, que promovem a precipitação de carbonatos de cálcio e magnésio; por outro lado, a respiração celular libera gás carbônico para o ambiente.

A biodegradação da matéria orgânica consiste predominantemente em transformar o excesso de resíduo existente nos corpos de água em carbono, fósforo, enxofre, etc. para o estado elementar. Isso é parte da chave do ciclo biogeoquímico para formação de adubos orgânicos e inorgânicos que podem ser utilizados para melhorar o solo.

O gás metano é formado a partir da fermentação da biomassa por bactérias chamadas metano-bactéria, que atuam principalmente sobre os sedimentos acumulados no fundo dos reservatórios, rios, tanques de fermentação de esgotos e efluentes.

\subsubsection{Biodegradação bacteriana de hidrocarbonetos}

A alta oxidação de compostos de hidrocarbonetos em condições aeróbicas é realizada através de Micrococcus, Pseudomonas, Mycobacterium, Nocardia, entre outras. Esse processo é muito importante para o meio ambiente e para os sistemas de tratamento de efluentes e para a biorremediação de solo e aqüiferos contaminados (MANAHAN, 1993).

A bactéria inicia sua ação sobre os compostos (hidrocarbonetos), convertendo os terminais $-\mathrm{CH}_{3}$ em grupos $\mathrm{CO}_{2}$, por meio de reações chamadas $\beta$-oxidação, nas quais os átomos são retirados. No 
caso de aromáticos, o processo de quebra é realizado por meio da clivagem do anel aromático, adicionando grupos $\mathrm{OH}^{-}$na posição adjacente ao átomo de carbono. Os hidrocarbonetos homociclicos são completamente biodegradados por microorganismos em condições aeróbicas na presença de moléculas de oxigênio, como um receptor de elétrons na respiração microbiana. Os homoaromáticos são moléculas redutoras nos processos de transformação (GRBIC-GALIC et al., 1991).

\subsubsection{Tratamento físico-químico}

O tratamento físico-quimico para clarificação do efluente utiliza o processo de floculação e precipitação. Essa técnica é um processo de separação que remove as substâncias orgânicas e inorgânicas dos efluentes pela adição de substâncias químicas que causam a formação de pequenas partículas, que, após aglutinarem, precipitam na forma de um sólido insolúvel no meio. Os sólidos formados são separados por meio de sedimentação e filtração. Essa técnica gera o efluente tratado, que poderá ser submetido ao tratamento biológico, gerando um residuo que deverá ser incinerado.

A EPA (1979) realizou um estudo em 16 unidades de tratamento físico-químico, visando avaliar a remoção de poluentes convencionais e tóxicos presentes nas águas residuárias provenientes de indústrias de tintas. Nesse estudo, concluiu-se que sólidos em suspensão, óleos e graxas foram removidos em mais de $70 \%$. Poluentes inorgânicos foram removidos com taxa acima de $69 \%$ para arsênio, cádmio, cobre, mercúrio, chumbo, níquel e zinco. $O$ tratamento físico-químico também removeu solventes orgânicos, como benzeno, tetracloreto de carbono, etil benzeno, tetracloroetileno, cloreto de metileno e tolueno, que apresentaram uma remoção acima de $60 \%$. 


\subsubsection{Tratamento biológico}

A biodegradação de matéria orgânica ocorre principalmente nos sistemas de tratamento de esgoto municipal e dos efluentes industriais na fase do tratamento biológico. $O$ processo de depuração microbiana é muito importante para mineralizar os poluentes solúveis na água.

O tratamento biológico consiste na biodegradação de matéria orgânica e de substâncias nocivas em efluentes industriais. Geralmente é aplicado quando a concentração dos constituintes orgânicos estão acima de $1 \%$. Esse processo é também aplicado para a remoção de metais em baixas concentrações, na qual o contaminante poderá ser retido no biolodo (EPA-BDAT, 2000).

\subsubsection{Estratégia de amostragem}

A estratégia de amostragem foi baseada na situação mais critica, ou seja, todas as amostras foram coletadas na sexta, em virtude da maior probabilidade de encontrar os resíduos dos componentes do grupo BTEX presentes no efluente. Durante a semana, os equipamentos que são utilizados para a fabricação de tintas são lavados com uma solução de hidróxido de sódio a $30 \%$ em água e posteriormente os resíduos gerados são armazenados em um tanque para ser tratado no final de semana.

Para a determinação do grupo BTEX foram coletadas amostras de água provenientes do tanque de estocagem antes do tratamento físicoquímico, após o tratamento físico-quimico, do tanque de equalização e das três lagoas de estabilização, em quatro períodos (verão, outono, inverno e primavera), de forma a abranger os 12 meses do ano. Foram divididas em cinco períodos, ou seja, verão de 2002 (três amostras em dezembro), verão de 2003 (oito amostras, sendo duas em janeiro, duas em fevereiro, duas em 
março, uma em dezembro e uma em janeiro de 2004), outono de 2003 (sete amostras, sendo duas em abril, três em maio, duas em junho), inverno de 2003 (sete amostras, sendo uma em julho, duas em julho, duas em agosto e duas em setembro) e primavera de 2003 (seis amostras, sendo duas em outubro, duas em novembro e duas em dezembro), totalizando 31 coletas de cada etapa do tratamento, perfazendo um total de 186 amostras analisadas.

De cada um dos pontos de coleta indicados acima, foi retirada uma amostra simples de $300 \mathrm{~mL}$ de água por meio de um tubo de vidro a uma profundidade de $30 \mathrm{~cm}$.

Imediatamente após serem coletadas, as amostras foram refrigeradas e mantidas a $4^{\circ} \mathrm{C}$ para que sua integridade não fosse alterada. Todas as análises foram realizadas no dia seguinte à armazenagem. 


\subsection{Cromatografia em fase gasosa}

Entre os métodos modernos de analítica instrumental, a cromatografia ocupa lugar de destaque, em virtude de sua facilidade em efetuar a separação, identificação e quantificação das espécies químicas, por si só, ou em conjunto com outras técnicas de análise instrumental. Os termos cromatografia, cromatograma e método cromatográfico são atribuídos ao botânico russo Mikhael Semenovich Tswett, que em 1906 utilizou esses termos em dois trabalhos que descreviam suas experiências na separação dos componentes de extratos vegetais de folhas e de gema de ovo. Esse nome deriva das palavras gregas "Chom" (cor) e "Graphe" (escrever), embora esse processo não dependa efetivamente da cor, exceto para facilitar a visualização da separação dos componentes e sua identificação (COLLINS e BRAGA, 1987).

A cromatografia é um método fisico-químico de separação dos componentes de uma mistura, realizado por meio da distribuição desses componentes entre duas fases, que estão em contato constante. Uma das fases permanece estacionária, enquanto a outra se move por meio dela. Basicamente, o método de cromatografia em fase gasosa consiste em se injetar uma porção da amostra (mistura de soluto) em um bloco aquecido, no qual imediatamente se vaporiza e é arrastado para dentro da coluna por um fluxo de gás inerte constante. Os solutos são absorvidos, já no inicio da coluna, pela fase estacionária e, depois de alguns segundos, são novamente dessorvidos por uma outra porção de gás de arraste. Esse processo repetese sucessivamente várias vezes à medida que a mistura se desloca pela coluna até atingir o seu final. 


\subsection{1 $\quad$ sistema de cromatografia gasosa}

O sistema cromatográfico é composto de um cromatógrafo e um integrador com "plotting" ou um sistema de tratamento de dados, para gerar e calcular o cromatograma. $O$ cromatógrafo consiste em um injetor de amostra, gases especiais, um forno com controle de temperatura, coluna cromatográfica e um detector (Figura 1) (WILLARD et al.,1979).

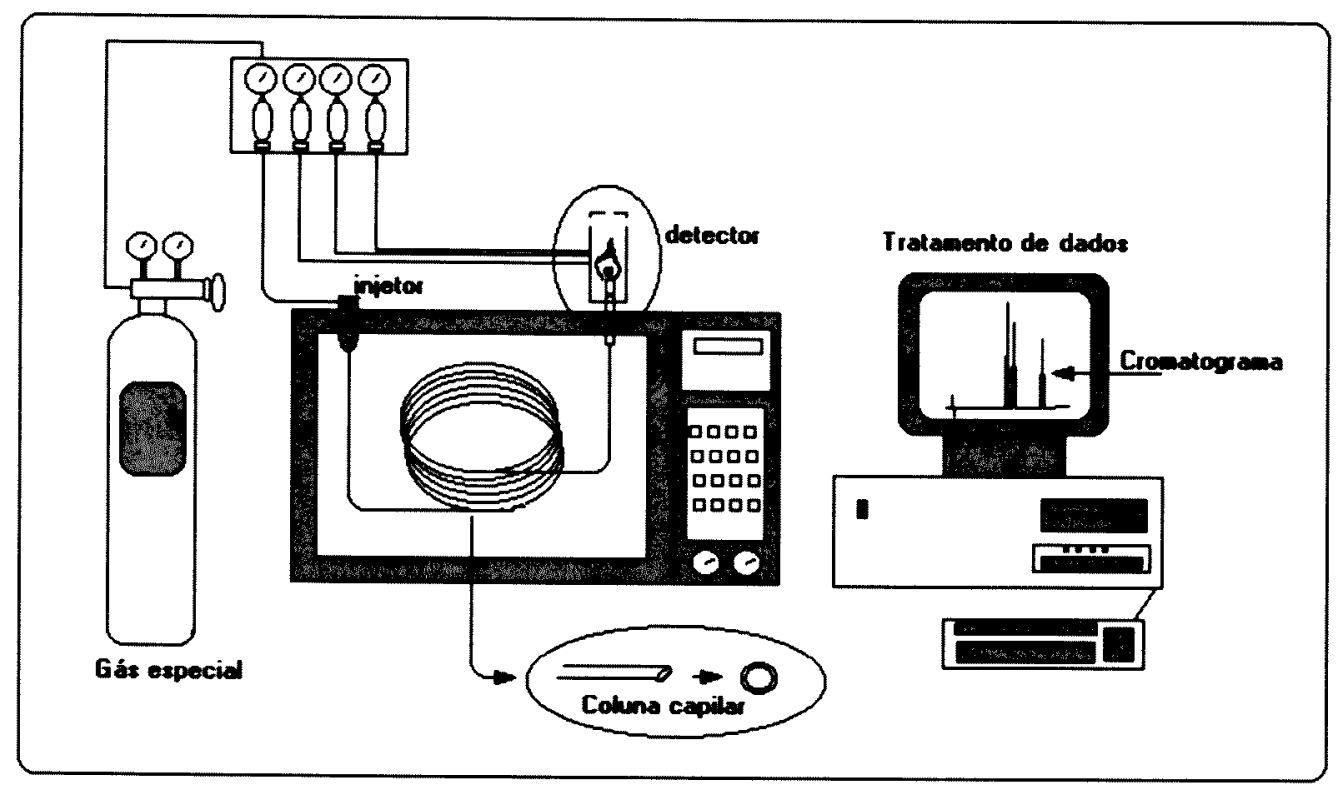

Figura 1 - Esquema de um cromatógrafo a gás.

\subsubsection{O gás de arraste}

O gás de arraste utilizado na cromatografia em fase gasosa deve ser inerte em relaçăo à fase estacionária e à amostra. A escolha do gás está relacionada ao tipo de trabalho a ser realizado, e o tempo de análise e a sensibilidade do detector podem ser influenciados pelas propriedades do gás (STEPHEN, 1975 e 1978). Os gases mais utilizados na cromatografia em fase gasosa são: hélio, nitrogênio, argônio e hidrogênio, 
sendo este último o mais perigoso em virtude de ser potencialmente inflamável quando misturado ao ar atmosférico (COLLINS e BRAGA, 1987). Entretanto tem menor viscosidade, proporcionando uma melhora na separação das substâncias químicas em análise.

\subsubsection{Injetores}

A injeção da amostra representa um dos problemas mais difíceis da cromatografia em fase gasosa. Esses sistemas são constituidos por câmaras aquecidas pelas quais a amostra e o gás de arraste são introduzidos. A temperatura estabelecida para realizar a análise deve ser suficiente para vaporizar instantaneamente a amostra ou provocar a dessorção rápida dos analitos quando se utiliza a técnica de SPME, mas não pode ser excessiva para não provocar a decomposição da substância que está sendo analisada.

A amostra deverá ser introduzida no menor tempo possivel para evitar fracionamento do material. Para que possamos ter um cromatograma reprodutivel e uma análise com alto grau de precisão, necessitamos introduzir sempre da mesma forma, no mesmo tempo e o mesmo volume de amostra (WILLARD et al., 1979).

Para a análise em que o analito está em baixa concentração, é necessário utilizar o injetor splitless, que ajuda a concentrar os analitos da amostra. Para injeções realizadas com a técnica SPME, é necessário utilizar um liner com $0,7 \mathrm{~mm}$ de diâmetro para diminuir a dispersão do analito, como também proporcionar picos simétricos (LANGENFELD, 1996). 


\subsubsection{Colunas}

A coluna cromatográfica é a principal responsável pela separação dos componentes da amostra. A escolha da coluna apropriada é uma decisão importante e difícil e alguns parâmetros devem ser muito bem avaliados para que a decisão seja coerente e eficaz (MOTA e ROSA, 1987).

As colunas empacotadas podem ser preenchidas com um suporte sólido impregnado com uma fase líquida ou um sólido ativo. Utilizando um sistema parecido, nas colunas capilares a fase líquida é distribuída pelas paredes internas do tubo capilar de forma homogênea, proporcionando uma grande área de contato, contribuindo significativamente para melhorar a separação e seletividade (WILLARD et al., 1979).

\subsubsection{Detectores}

Os detectores são equipamentos que indicam a presença e a quantidade de substâncias que eluem da coluna, sendo o sinal detectado diretamente proporcional à concentração de cada substância presente em uma amostra. As principais características que devem ser consideradas em um detector para a realização de uma análise são: sensibilidade, seletividade, nível de ruído, resposta e linearidade. $O$ detector de ionização de chama é muito sensivel para análise de hidrocarbonetos aromáticos, facilitando a deteç̧ão de baixas concentraçōes. 


\subsection{Preparação da amostra ambiental}

\subsubsection{Preparação da amostra}

As amostras ambientais não podem ser analisadas diretamente sem um pré-tratamento. São muitas vezes diluídas, complexas e, em alguns casos, são simplesmente incompativeis com a sensibilidade das técnicas analiticas existentes. Para que essas substâncias sejam analisadas por meio de uma determinação instrumental, elas devem ser extraidas, limpas ("cleanup") e concentradas.

Dependendo das características físico-químicas das amostras, procedimentos especiais devem ser adotados para a remoção de substâncias indesejáveis, como também isolar e concentrar os analitos da amostra matriz. De qualquer modo, sem considerar a natureza da amostra, após o tratamento são obtidas várias frações da amostra principal; as substâncias de interesse ficam concentradas e são compatíveis com a sensibilidade da técnica analítica escolhida (SONIASSY, 1990).

As técnicas de extração são normalmente muito complexas, mas permitem isolar as substâncias orgânicas voláteis e semi voláteis encontradas no meio ambiente, principalmente no solo, na água, nos vegetais e animais.

\subsubsection{Extração de compostos voláteis}

Os métodos de separação e concentração dos analitos voláteis de interesse são complexos e de difícil manuseio. Alguns métodos para "clean-up" de amostra ambiental utilizam grandes quantidades de solventes orgânicos, muitas vezes com um certo grau de toxicidade (EISERT e LEVSEN, 1996). 
Métodos instrumentais para extração, como o purge and trap, o headspace, a cromatografia líquida de alta eficiência e a extração por fluido supercrítico são técnicas consagradas, entretanto de custo elevado para a maioria dos laboratórios e indústrias, impossibilitando sua ampla aplicação.

Técnicas de absorção e clean-up têm custo analítico menor, entretanto utilizam grande quantidade de solventes orgânicos para extração e concentração dos analitos, o que contraria as diretrizes do Green Chemistry, expondo os técnicos dos laboratórios a solventes tóxicos, como também gerando maior quantidade de resíduos. Técnicas como a SPME conjugam simultaneamente a extração com posterior dessorção do analito, de forma rápida e eficiente, sendo mais adequadas para realizar a extração e concentração dos analitos, pois não utilizam solventes durante sua aplicação.

\subsubsection{Extração por meio da fibra SPME (Microextração em Fase Sólida)}

A técnica de Microextração em Fase Sólida (SPME) foi desenvolvida no início dos anos 90 por PAWLISZYN et al. (1997), com a finalidade de facilitar a extração de vários tipos de substâncias de amostras aquosas e do ar. Essa técnica está fundamentada no princípio do equilíbrio de partição entre o analito e a amostra aquosa ou dos vapores formados sobre a camada do líquido headspace e da fibra de sílica fundida recoberta com uma fase estacionária.

A seletividade da extração depende do tipo de fibra a ser utilizada e é proporcional à concentração do analito na amostra matriz, seja ela água ou ar. A técnica SPME é uma combinação de técnicas de amostragem, extração, concentração e introdução dos analitos da amostra no sistema cromatográfico em um único passo (GROTE, 1997). 
Em virtude da facilidade de ser utilizada, essá técnica tem sido muito útil para a determinação de várias substâncias em amostras ambientais, tais como compostos orgânicos voláteis (BUCHHOLZ et al., 1993), hidrocarbonetos policíclicos aromáticos e bifenilas policloradas, (BELARDI et al., 1989), BETX (ARTHUR e PAWLISZYN, 1990; POTTLER et al., 1992; ARTHUR et al., 1992; SARNA et al., 1994; MOTLAGH e PAWLISZYN, 1993; MACGILLEVRA, 1994; ZHANG e PAWLISZYN, 1993, 1994 e 1995; GORECKI e PAWLISZYN, 1995; DJOZAN e ASSADI, 1997; MATISOVÁ et al., 1999; VALOR e CORTADA, 1996 e MENÉNDEZ et al., 2000), pesticidas (POPP et al., 1999), e em diversos tipos de matrizes ambientais, tais como água de consumo humano, efluentes industriais, esgotos, amostras de fluidos biológicos, como sangue e urina, entre outras.

A técnica de extração das amostras por meio da fibra consiste basicamente em dois estágios distintos que podem ser observados na figura 2: o primeiro é o processo de adsorção do analito na amostra matriz aquosa, de forma que a fibra é mergulhada (exposta) diretamente na amostra aquosa ou nos vapores do headspace.

No segundo estágio, já decorrido o tempo de extração, aplicase o processo de dessorção térmica dos analitos retidos na camada polimérica dentro do injetor do cromatógrafo gasoso.

O analito é transferido diretamente para dentro da coluna por meio do fluxo contínuo do gás de arraste. Essa técnica traz grande vantagem em relação às anteriores, principalmente por facilitar a manipulação com pequenas amostras entre 1 e $5 \mathrm{~mL}$, ser seletiva para vários compostos e possibilitar a concentração do analito na própria fibra, sem a necessidade de se ter vários estágios intermediários. Em alguns casos, a própria fibra pode ser utilizada como sistema de amostragem no campo e ser armazenada sob refrigeração até a análise. 
O sistema é constituido de uma fibra de sílica fundida com aproximadamente $1 \mathrm{~cm}$ de comprimento, $0,05 \mathrm{~mm}$ de diâmetro e recoberta com um polimero. Ela é fixada em uma haste de aço inox instalada dentro de um suporte semelhante a uma microsseringa.

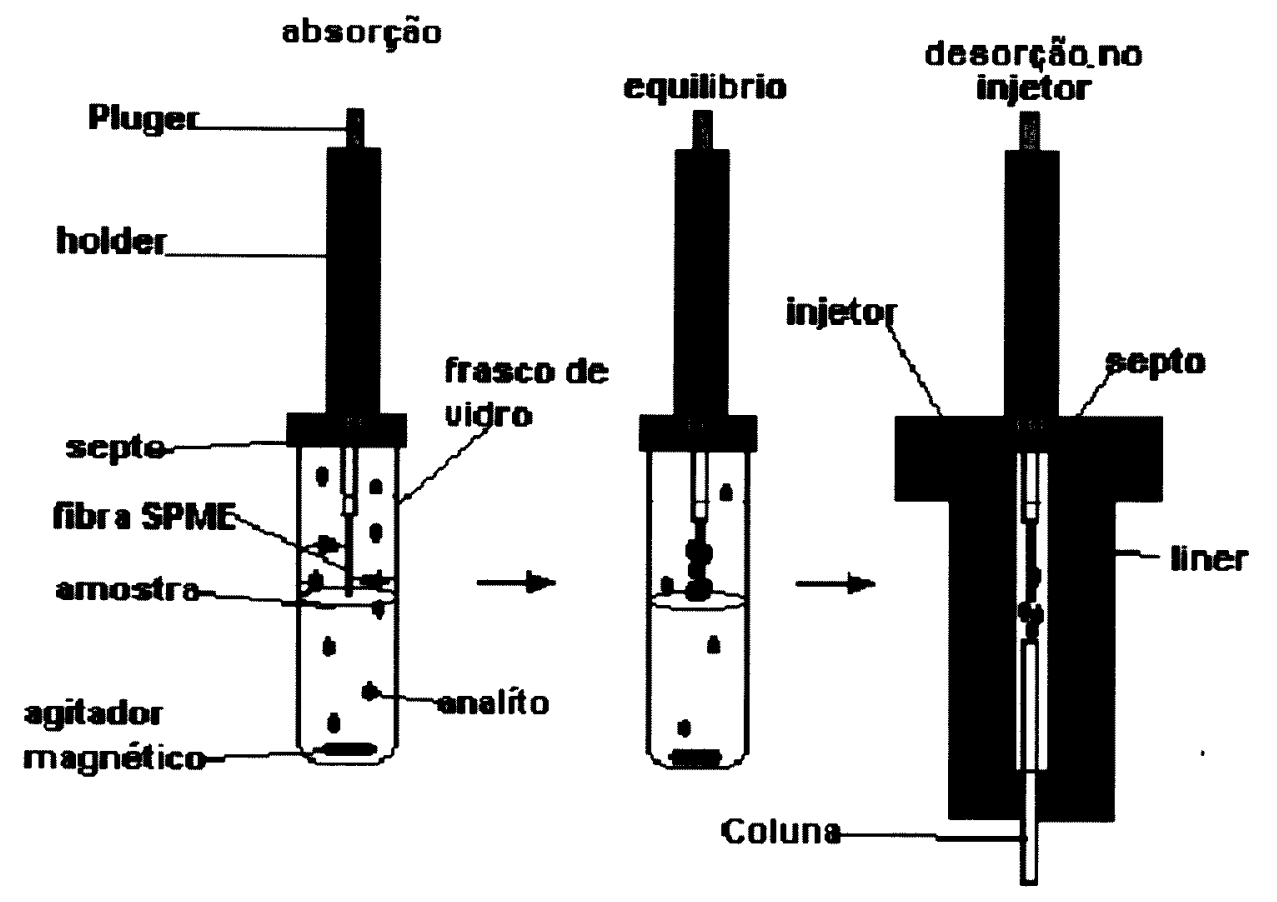

Figura 2 - Esquema da técnica SPME, demonstrando-se o estágio de extração por adsorção, equilibrio e dessorção dentro do injetor (SUPELCO, 1998).

A haste metálica move a fibra de sílica fundida no sentido longitudinal de dentro para fora da agulha do sistema de SPME, de forma a protegê-la de danos físicos. No momento de se realizar a amostragem, deve-se recolher a fibra para dentro da agulha para protegê-la durante o processo de perfuração do septo de silicone do frasco amostrador. Uma vez dentro do frasco, a fibra deve ser colocada sempre na mesma posição e altura de extração. Pressionando-se a haste para baixo, a fibra é exposta diretamente na amostra ou na fase vapor headspace, sobre o líquido da amostra. 
Nessa fase, os analitos são adsorvidos pelo polímero que recobre a fibra. Após ser atingido o tempo de equilibrio de adsorção, usualmente entre 2 a 30 minutos, a fibra é recolhida para dentro da agulha e retirada para fora do frasco amostrador. Finalmente, a agulha é introduzida no injetor de um cromatógrafo gasoso, no qual é realizada a dessorção dos analitos diretamente para a coluna do cromatógrafo; após o tempo de dessorção, a fibra é recolhida para dentro da agulha e retirada do injetor.

\subsubsection{Teoria da extração por SPME}

A técnica de Microextração em Fase Sólida (SPME) baseia-se no princípio do equilíbrio da concentração do analito da amostra ou dos vapores do headspace sobre o liquido da amostra, com o analito extraído e retido no recobrimento polimérico da fibra. A quantidade de analito adsorvida pela fibra depende da espessura do recobrimento polimérico e da constante de distribuição do analito. O tempo de extração é determinado pelo tempo necessário para se obter uma extração quantitativa dos analitos.

A adsorção do analito na fase sólida eleva-se com o aumento do peso molecular e do ponto de ebulição. A seletividade pode ser alterada pela troca do tipo de recobrimento polimérico da fibra ou pela espessura do próprio recobrimento em uso, de forma a obterem-se as melhores características físico-químicas para extrair o analito de interesse. Em geral, as substâncias mais voláteis necessitam de filmes mais espessos de recobrimento, enquanto as semi voláteis necessitam de filmes mais finos para se obter uma adsorção e dessorção efetiva. Para recobrimentos poliméricos líquidos, a quantidade do analito adsorvido pelo recobrimento pode ser relacionada diretamente com a concentração do analito na amostra (ZHANG et al., 1994). 
Essa técnica baseia-se na partição entre o analito da amostra aquosa e a fibra polimérica, sendo este o principal princípio de extração do sistema SPME. O modelo matemático para o processo de adsorção dinâmico foi desenvolvido por LOUCH et al. (1992). O analito da amostra é adsorvido pela fase polimérica até atingir o equilibrio (deve ser assumido volume infinito), sendo proporcional à concentração do analito na solução aquosa e, dessa forma, é determinado o coeficiente de partição.

O coeficiente de partição é demonstrado conforme a equação abaixo:

$$
n=\frac{K_{f s} \cdot V_{f} \cdot C_{0} \cdot V_{s}}{K_{f s} \cdot V_{f}+V_{s}}
$$

Onde:

$$
\begin{aligned}
& n=\text { massa do analito adsorvido pelo filme polimérico. } \\
& \mathbf{C}_{\mathbf{o}}=\text { concentração inicial do analito na amostra. } \\
& \mathbf{K}_{\mathbf{f}}=\text { coeficiente de partição para o analito entre o recobrimento } \\
& \text { e a amostra matriz. } \\
& \mathbf{V}_{\mathbf{f}}=\text { volume do filme. } \\
& \mathbf{V}_{\mathbf{s}}=\text { volume da amostra. }
\end{aligned}
$$

Essa equação demonstra basicamente o comportamento entre a concentração inicial do analito na amostra e a quantidade do analito adsorvido pelo filme polimérico que é linear, isso porque os filmes utilizados em SPME são seletivos, têm forte afinidade com compostos orgânicos e melhoram a extração dos analitos, consequentemente o filme polimérico têm grande efeito de concentração e boa sensibilidade. 
Usualmente os valores de Kfs (coeficiente de partição) para o analito não são suficientemente grandes para extrações longas da amostra matriz. O método de amostragem SPME baseia-se no equilibrio do sistema, havendo, dessa forma, necessidade de se realizar uma calibração utilizandose padrões puros e conhecidos para se determinar as concentrações dos analitos de interesse.

A equação também demonstra que, se o Vs (volume da amostra) for muito grande, a quantidade de analito extraido pelo filme da fibra não é relativa ao volume da amostra. Em virtude dessa propriedade, a técnica de SPME também é apropriada para amostragens de campo e análises.

A técnica de SPME reproduz resultados precisos da concentração do analito por meio de uma simples exposição no ar ou diretamente em um lago, rio, poço ou reservatórios de água. Para amostras de solo, é necessário realizar uma extração prévia do analito. O processo de extração SPME pode reduzir significativamente o tempo de análise por causa da combinação da técnica de amostragem, extração, concentração e, finalmente, dessorção em um processo simples de injeção (ARTHUR et al., 1992).

\subsubsection{Coleta com a fibra}

Para uma excelente precisão e exatidão, devemos observar alguns parâmetros muito importantes, como o tempo de coleta, que define 0 equilíbrio do sistema. Também é importante manter constantes o tamanho do frasco amostrador e o volume e, quando se utilizar amostragem por imersão, deverá manter-se sempre a mesma altura da fibra imersa no liquido. O ajuste correto da fibra tanto para imersão como para o sistema headspace implica diferentes cinéticas de extração (YANG et al., 1994). 
Em alguns casos, a amostragem mostrou-se mais eficiente no sistema headspace do que por imersão, por atingir-se rapidamente o equilibrio, já que os analitos podem difundir-se muito mais rápido no recobrimento da fibra. Essa caracteristica pode ser uma vantagem para a adsorção dos componentes na amostra. O sistema de amostragem via headspace é ideal para minimizar a ação de interferentes na análise, como também para prolongar a vida útil da fibra SPME.

Foi observado por Harmon et al. (1997) que, nas análises de aromatizantes na presença de glicerina, o sistema de extração por headspace eliminou a presença do pico da glicerina e ganhou em sensibilidade com o aumento da absorção de mais de 13 outros compostos.

\subsubsection{O processo de adsorção e dessorção}

O processo de dessorção da fibra SPME depende diretamente do ponto de ebulição do analito, da espessura do recobrimento e da temperatura da câmara de injeção do injetor. Em alguns casos, há a necessidade de resfriar o injetor por um processo criogênico para realizar lentamente a dessorção dos compostos dentro do injetor capilar (SUPELCO, 1998).

Um ponto importante que se deve observar é o diâmetro interno do liner do injetor, pois os lineres convencionais com $2 \mathrm{~mm}$ de diâmetro provocam grande dispersão dos compostos; conseqüentemente deixa os picos dos analitos mais largos e menos definidos. Para eliminar esse problema, é necessário utilizar um liner especial com $0,7 \mathrm{~mm}$ de diâmetro interno, que diminui a dispersão dos compostos durante a dessorção, deixando os picos mais finos, com melhora da definição (SUPELCO, 1998). 


\subsubsection{Otimização dos parâmetros para uma análise utilizando-se as fibras SPME}

Quando não conhecemos os compostos, podemos ter dificuldades em extraí-los com a fibra. Em alguns casos, os resultados obtidos podem ser inadequados.

A polaridade, a espessura do filme do revestimento, a velocidade da agitação, o método de extração (headspace ou imersão), o $\mathrm{pH}$, ○ conteúdo de sal, o volume de amostra, a água utilizada para preparação dos padrões ou outros fatores podem contribuir para erros durante a análise. É importante lembrar que se deve determinar um tempo adequado para extração, de forma que se atinja o equilíbrio necessário para que as concentrações das moléculas livres nas amostras e no revestimento sejam iguais. Os seguintes parâmetros devem ser considerados: tempo de coleta, temperatura e profundidade da fibra imersa na amostra aquosa ou sobre os vapores de headspace (SUPELCO, 1998).

\subsubsection{Polaridade da fibra SPME}

A polaridade, sem dúvida, tem grande influência no processo de extração, pois a fibra, com aproximadamente $1 \mathrm{~cm}$ de comprimento, é exposta diretamente na amostra. Essas fibras podem ser polares ou apolares; muitas vezes pequenas modificações de ambiente quimico não são significativas.

A adição de um polímero à base de divinil benzeno com um polietileno glicol (Carbowax) pode aumentar a polaridade da fibra, melhorando a extração de moléculas polares, como alcoóis e aminas. Também são citadas na literatura algumas modificações com adição de sílica e carbono (SUPELCO, 1998). 


\subsubsection{Espessura da fibra SPME}

A difusão do analito da amostra matriz para dentro dos poros do filme que recobre a fibra é proporcional à espessura desse recobrimento. Filmes com maior espessura retêm melhor compostos voláteis e podem ser transferidos diretamente para a câmara do injetor do cromatógrafo a gás sem perdas.

Para compostos com alto ponto de ebulição são indicados filmes mais finos, pois a difusão é rápida durante a extração e dessorção térmica. Filmes finos removem mais efetivamente os compostos com alto ponto de ebulição da amostra. Dessa forma, deve-se ter maior cuidado durante a análise para não haver contaminação cruzada entre as extrações (SUPELCO, 1998).

\subsubsection{Agitação da amostra}

A agitação pode aumentar ou reduzir significativamente o tempo de extração, especialmente para analitos com moléculas de alto peso molecular e alto coeficiente de difusão. A agitação irregular ou baixa pode causar baixa precisão da extração dos analitos (SUPELCO, 1998).

Não é aconselhável utilizar banhos de ultrassom para extração por imersão, pois eles podem aquecer a amostra e causar perdas, mas esse processo pode beneficiar a vaporização dos analitos para uma extração utilizando a técnica headspace. 


\subsubsection{Extração por imersão $\times$ headspace, adição de sal e modificação do pH da solução}

Os analitos podem ser coletados diretamente por imersão da fibra na amostra ou pela exposição da fibra sobre a superfície da amostra. Os compostos com baixa pressão de vapor são coletados normalmente por meio de headspace e os de alta pressão de vapor, por imersão direta da fibra na amostra.

A adição de sal (cloreto de sódio) na amostra ou a alteração de $\mathrm{pH}$ podem aumentar a força iônica do meio, aumento ou diminuição da solubilidade do analito na solução aquosa. A combinação da adição de sal com a modificação do pH aumenta a extração do analito quando se utiliza a técnica headspace (SUPELCO, 1998). 


\section{$1.5 \quad$ Amostragem}

\subsubsection{Técnicas de amostragem}

O objetivo de uma amostragem é obter uma amostra representativa, de forma a evitar erros na determinação dos compostos em estudo, como também evidenciar com precisão a extensão e a natureza da contaminação.

A representatividade da amostra está relacionada ao controle do método de amostragem e de sua preservação até a análise final. Conhecer o local da amostragem faz-se necessário para a escolha da técnica de amostragem (NDDH, 2001).

As técnicas de amostragem podem ser simples ou compostas. A amostra pode ser simples, ou seja, somente uma amostra é coletada no local da amostragem. Essa técnica é indicada quando a água residual apresenta características relativamente constantes (homogêneas). A amostra composta consiste na combinação quantitativa de várias amostras simples do mesmo local. Isso é conveniente quando a água residual apresenta variações na sua composição ao longo da área a ser amostrada. As amostras podem compor-se com base no tempo de amostragem ou na vazão adequada para a determinação de compostos orgânicos voláteis (BROWER ot al., 1986).

As técnicas de amostragem podem ser manuais ou automáticas. Para serem utilizados os sistemas automáticos, é necessário conhecer qualitativamente os tipos de compostos que serão amostrados, em virtude de algumas partes internas dos amostradores serem de materiais sensiveis à ação de solventes orgânicos. 
Os equipamentos de amostragem automáticos mais sofisticados são geralmente construídos em polietileno, aço inox ou teflon, que minimizam a interferência dos componentes internos dos equipamentos, mantendo a integridade da amostra. Esses equipamentos apresentam mais vantagens sobre o manual porque minimizam erros de amostragem. Para compostos voláteis, observou-se que a coleta manual apresenta melhores resultados (BROWER et al., 1986).

Durante a coleta da amostra, deve evitar-se ao máximo a formação de bolhas, por causa de sua aeração, procurando-se realizar a coleta em locais de baixa turbulência e abaixo da superfície, para evitar a perda de compostos voláteis. Ao se coletar a amostra, o frasco receptor deverá ser completamente preenchido para evitar espaço vazio entre a tampa e a superfície da amostra. Esse procedimento evita a perda dos compostos voláteis que podem passar para a fase gasosa e serem liberados quando o frasco for aberto.

\subsubsection{Escolha da embalagem a ser utilizada como recipiente de coleta}

Estão disponiveis no mercado vários tipos de embalagens de diferentes materiais. Os frascos amostradores podem ser fabricados à base de policloreto de vinila (PVC) ou de compostos acrilicos; entretanto, os frascos de vidro são os mais inertes (NDDH, 2001).

Os frascos de vidro são os mais utilizados e adequados em amostragem ambiental, por serem praticamente inertes. Algumas amostras devem ser acondicionadas em frascos de vidro especiais quando $0 \mathrm{pH}$ da amostra estiver nos extremos da escala. Alguns metais podem depositar-se nas paredes do vidro causando a perda do analito. 
As embalagens de material plástico não são muito adequadas para a coleta de amostras que tenham grande concentração de substâncias orgânicas perigosas, principalmente com a presença de solventes. Com exceção do teflon e de alguns polimeros fluorados, que são substâncias praticamente inertes e de baixa porosidade, a maioria dos compostos podem migrar para as paredes porosas dos frascos de plásticos, provocando a perda do composto de interesse analítico.

Dependendo do tipo de substância orgânica presente na amostra, poderá ocorrer lixiviação de monômeros livres, plastificantes e antioxidantes presentes no material polimérico, aumentando assim a possibilidade de contaminação cruzada da amostra, como também poderão identificar-se e determinar-se substâncias que não estão presentes na amostra matriz. Em virtude de alguns compostos poliméricos serem suficientemente porosos, poderá haver migração do analito volátil por meio das paredes do frasco.

\subsubsection{Acondicionamento e preservação da amostra}

As amostras ambientais, tais como esgoto doméstico, efluentes industriais, água tratada para consumo, subterrâneas, etc. são de difícil preservação em virtude da presença de microorganismos e substâncias que podem reagir ou combinar com os compostos em estudo. A preservação da amostra, após ser removida do ambiente natural, pode ser prolongada utilizando algumas substâncias químicas que inibem a ação biológica e de algumas substâncias químicas presentes (EPA, 1983).

Os métodos de preservação, embora relativamente limitados, geralmente melhoram o retardamento da ação biológica, de hidrólises químicas dos compostos e complexos, da redução da volatilização dos constituintes voláteis e da redução dos efeitos de absorção. Os métodos 
empregados normalmente são o controle de $\mathrm{pH}$, a adição de substâncias químicas, a refrigeração da amostra a $4^{\circ} \mathrm{C}$ e o congelamento (RADTKE, 1999).

Para evitar o risco de perdas das substâncias voláteis por volatilização, as amostras deverão ser acondicionadas em vidros âmbar com batoques de silicone ou teflon, providos de tampas em polietileno de alta densidade ou metal. Durante o periodo de estocagem, as amostras deverão permanecer em local protegido da luz, pois algumas substâncias orgânicas são fotossensiveis, isto é, podem degradar ou recombinar-se com outras substâncias presentes na solução, em virtude da ação da luz.

Após a coleta da amostra, ela deve permanecer fechada por um período e deverá manter as mesmas do momento da amostragem. Alguns efeitos físico-químicos podem degradar a amostra; dessa forma, as amostras de água subterrânea e de superfície devem ser rapidamente refrigeradas para uma temperatura segura de $4 \pm 2^{\circ} \mathrm{C}$ com gelo e serem estocadas em refrigerador, num intervalo máximo de 14 dias entre a coleta da amostra e a análise (SOWINSKI e BAUGHMAN, 1998).

Alguns estudos demonstraram que as amostras coletadas e acondicionadas em frascos de vidro, preenchidos na sua totalidade, selados com batoque de borracha de silicone ou teflon, envolvidos por uma fita de teflon e lacrados com alumínio, permaneceram estáveis à temperatura ambiente $\left(24^{\circ} \mathrm{C}\right)$ entre oito e dez dias (BELLAR e LICHTENBERG, 1974).

A American Standalization Technical Methods - ASTM (1996) recomenda que as amostras destinadas à determinação de compostos voláteis sejam estocadas a $4^{\circ} \mathrm{C}$, no escuro e, no máximo, por duas semanas.

Em virtude de as amostras ambientais contendo hidrocarbonetos aromáticos leves (benzeno, tolueno, etil benzeno e xilenos 
(BTEX) se degradarem durante a estocagem, elas devem ser aciduladas com ácido clorídrico (1:1) para um pH abaixo de 2 (SOWINSKI e BAUGHMAN, 1998).

Amostras de água contendo grandes quantidades de carbonatos, bicarbonatos solúveis, entre outras substâncias, reagem imediatamente com o agente preservativo, com efervescência da amostra. Por causa desse processo, os compostos voláteis são arrastados pelas bolhas formadas, com perdas significativas dos compostos de interesse.

Para um eficiente controle das amostras, é necessário obedecer a alguns requisitos básicos, como preencher adequadamente a etiqueta, que deverá conter as seguintes informações:

1 - Localização exata da coleta;

2 - Data e tempo da coleta;

3 - Indicação do tipo de coletor utilizado e informações sobre a coleta;

4 - Indicação do tipo de preservativo utilizado;

5 - Algumas informações que chamaram a atenção durante a amostragem (coloração, temperatura, $\mathrm{pH}$, aparência, etc.). 


\section{OBJETIVOS}

\section{$2.1 \quad$ Objetivo geral}

Determinar a eficácia do sistema de tratamento de efluentes, avaliando a biodegradabilidade dos compostos do grupo BTEX nas diversas fases do processo de tratamento de efluentes, de forma a quantificar a presença desse grupo de compostos, utilizando-se a técnica de microextração SPME (Solid Phase Micro-Extration) e cromatografia a gás. Comparar os resultados obtidos com os limites máximos permitidos para a água potável.

\section{$2.2 \quad$ Objetivos específicos}

- Otimizar e validar um método analítico adequado, utilizando a técnica de extração e pré-concentração SPME (Solid Phase Micro-Extration) e quantificar os analitos por meio de cromatografia a gás;

- Avaliar o sistema de tratamento de efluentes de uma indústria de tintas, durante 12 meses, de forma a abranger as quatro estações climáticas, comparando os resultados obtidos do grupo BTEX na água após o tratamento dos efluentes com os limites máximos permitidos e avaliar o risco à saúde humana;

- Otimizar o método analítico atendendo aos critérios do Green Chemistry (EPA, 2004). 
3. MATERIAL E MÉTODOS

3.1 Material

3.1.1 Reagentes

- Benzeno pureza 99,5\% GC (Referência 12540 - Fluka Chemie AG);

- Tolueno pureza 99,5\% GC (Referência 89680 - Fluka Chemie AG);

- Etil benzeno pureza 99,5\% GC (Referência 03979 - Fluka Chemie AG);

- p-xileno pureza $99,5 \%$ GC (Referência 95680 - Fluka Chemie AG);

- $m$-xileno pureza $99,5 \%$ GC (Referência 95670 - Fluka Chemie AG);

- o-xileno pureza 99,5\% GC (Referência 95660 - Fluka Chemie AG);

- Acetona PA com pureza > 99,5\% (Merck AG);

- Metanol grau cromatografia líquida com pureza $>99,5 \%$ (Merck AG);

- Água grau cromatografia líquida (purificada por meio de deionizador Milli $Q$ e purgada por 12 horas com gás hélio (Millipore Corp.) e água de poço semi-artesiano de 180 metros de profundidade;

- Gás nitrogênio grau cromatográfico com pureza 99,999\%;

- Gás hélio grau cromatográfico com pureza de 99,999\%;

- Gás hidrogênio grau cromatográfico com pureza de 99,999\%;

- Ar sintético grau FID;

- Cloreto de sódio PA com pureza > 99,5\% (Merck AG). 


\subsubsection{Equipamentos}

- Fibra SPME recoberta com $100 \mu \mathrm{m}$ de polidimetilsiloxano para análise manual de voláteis (Catálogo 5-7300 SupelcoSigma-Aldrich USA);

- Suporte manual para fibra SPME (Catálogo 5-7330 Supelco-Sigma-Aldrich USA);

- Placa aquecedora com agitador magnético (IKA - RH/KTC);

- Termômetro de mercúrio com escala de -10 a $60^{\circ} \mathrm{C}$, com subdivisões de $1^{\circ} \mathrm{C}$ (INCOTERM);

- Cromatógrafo a gás 6890 Plus com sistema de amostragem automática, munido de um injetor capilar e detector de ionização de chama (Hewlett Packard USA);

- Coluna capilar INNOWAX, 0,25 mm de diâmetro, 0,25 $\mu \mathrm{m}$ de filme de polietileno glicol com 60 metros de comprimento (Hewlett Packard USA);

- Pipeta automática com volume variável de 10 a $100 \mu \mathrm{L}$ (Hamilton US);

- Purificador de água Milli Q (Millipore Corporation);

- Balança analítica AB 204 (METTLER TOLEDO);

- Dessecador de vidro para vácuo com sílica gel (Pyrex).

\subsubsection{Materiais de consumo}

- Barras magnéticas para microrreação em frascos de 0,1 a 2 $\mathrm{mL}$ (Catálogo 23226 Supelco-Sigma-Aldrich USA);

- Frasco de vidro para amostrador automático com capacidade de $7 \mathrm{~mL}$ (Supelco-Sigma-Aldrich USA);

- Suporte universal para fixar o suporte da fibra SPME;

- Seringa de vidro com capacidade de 5 e $10 \mathrm{~mL}$; 
- Sistema de tratamentos de dados Workstation (Hewlett Packard USA);

- Balões volumétricos com vários volumes para preparação de padrões (Pyrex);

- Septos de silicone faceados com um filme de teflon para frasco de $7 \mathrm{~mL}$ (Catálogo 27155 Supelco-Sigma-Aldrich USA);

- Liner de vidro para injetor splitless com diâmetro interno de 0,7 mm (Catálogo 2-6375,05 Supelco-Sigma-Aldrich USA);

- Pipetas volumétricas com volumes de 1, 5, 10, 20 e $50 \mathrm{~mL}$ (Pyrex);

- Microsseringa com capacidade de $10 \mu \mathrm{L}$ (Hamilton n-701).

\subsubsection{Preparação dos frascos e materiais}

Os frascos de vidro utilizados para análise foram lavados com água e detergente e deixados mergulhados em uma solução de sulfocrômica durante 12 horas. Em seguida foram lavados com água corrente e deionizados pelo Milli $Q$ e colocados numa estufa a $230^{\circ} \mathrm{C}$ durante três horas. Os septos de silicone faceados com teflon também foram condicionados em estufa a $230^{\circ} \mathrm{C}$ durante três horas. Esse procedimento foi realizado para eliminar a interferência do efeito memória do material.

O cloreto de sódio PA foi seco em uma estufa a $230^{\circ} \mathrm{C}$ durante oito horas, eliminando, assim, todos os resíduos de solventes voláteis adsorvidos do ambiente do laboratório. Depois de seco, o cloreto de sódio e os outros materiais foram estocados em um dessecador para evitar a adsorsão de resíduos voláteis do ambiente, evitando-se, assim, contaminações cruzadas. 


\subsection{Método}

3.2.1 Condições cromatográficas otimizadas

Seguem abaixo as condições cromatográficas otimizadas para a análise do BTEX:

Cromatógrafo gasoso: $\quad$ HP-6890

Temperatura do detector FID: $250^{\circ} \mathrm{C}$

Fluxo de $\mathrm{H}_{2}$ :

$30 \mathrm{~mL} / \mathrm{minuto}$

Fluxo de Ar:

$350 \mathrm{~mL} /$ minuto

Gás auxiliar make-up:

$27,1 \mathrm{~mL} /$ minuto

Injetor capilar splitless: $250^{\circ} \mathrm{C}$ - (com liner de vidro com $0,7 \mathrm{~mm}$ de diâmetro)

Coluna: HP-INNOWAX - 0,32 mm de diâmetro, $0,25 \mu \mathrm{m}$ de filme de polietileno glicol com 60 metros de comprimento

Fluxo de gás de arraste: $\quad 2,9 \mathrm{~mL} /$ minutos de hidrogênio

Temperatura inicial: $40^{\circ} \mathrm{C}$

Tempo inicial: 10 minutos

Rampa de aquecimento 1: $\quad 5^{\circ} \mathrm{C} / \mathrm{min}$

Temperatura final: $\quad 100^{\circ} \mathrm{C}$

Rampa de aquecimento 2: $\quad 35^{\circ} \mathrm{C} / \mathrm{min}$

Tempo final:

1 minuto

Temperatura final:

$240^{\circ} \mathrm{C}$

Tempo final:

5 minutos 


\subsubsection{Preparação das soluções-padrão}

A solução-estoque concentrada foi preparada transferindo-se uma aliquota de $10 \mu \mathrm{L}$ de cada um dos padrōes do grupo BTEX (benzeno, tolueno, etil benzeno, $p$-xileno, $m$-xileno e o-xileno), com teor de pureza maior que $99,5 \%$ (Fluka Chemie $A G$ ), para um balão volumétrico de $10,0 \mathrm{~mL}$ e completado com metanol grau cromatográfico, obtendo-se, assim, uma solução com $865 \mu \mathrm{g} / \mathrm{L}$ de BTEX. Essa solução foi protegida com papelalumínio e estocada no freezer durante uma semana.

A partir dessa solução-padrão, preparamos diariamente as soluções analíticas de acordo com as concentrações $(1,5,10,50$ e 100 $\mu \mathrm{g} / \mathrm{L})$, e cada um das novas soluçōes foi diluida com água do poço semiartesiano, purgada com hélio puro durante 12 horas.

\subsubsection{Preparação da curva de calibração}

Em um frasco de $7 \mathrm{~mL}$ munido com tampa de polietileno e septo de silicone faceado com filme de teflon, previamente descontaminados, pesamos $1,0 \pm 0,05 \mathrm{~g}$ de cloreto de sódio $\mathrm{PA}$ e inserimos duas barras magnéticas no frasco. Com uma pipeta volumétrica, transferimos $5,0 \mathrm{~mL}$ da solução-padrão para o frasco de vidro e o tampamos rapidamente.

As determinações da curva de calibração foram iniciadas pelo menor ponto de concentração até o maior ponto da curva. Esse procedimento evita contaminação da fibra pelos padrões de maiores concentrações. 


\subsubsection{Preparação das amostras}

Deve-se seguir o mesmo procedimento de preparação dos padrões analíticos, ou seja, em um frasco de $7 \mathrm{~mL}$ munido com tampa de polietileno e septo de silicone faceado com filme de teflon, previamente descontaminados, pesamos $1,0 \pm 0,05 \mathrm{~g}$ de cloreto de sódio PA e inserimos duas barras magnéticas no frasco. Com uma pipeta volumétrica, transferimos $5,0 \mathrm{~mL}$ da amostra de água do sistema de tratamento para o frasco de vidro e o tampamos rapidamente.

As amostras de água contaminada que apresentaram concentrações acima da curva de calibração foram diluídas com água do poço semi-artesiano purgada com hélio puro durante 12 horas. Essa medida garante que todas as amostras possam ser analisadas na mesma curva de calibração.

\subsubsection{Extração dos analitos}

Os frascos com os padrões ou amostras devem ser transferidos para o suporte metálico dentro do banho-maria e fixados com uma garra metálica. A temperatura do banho-maria deve ser ajustada para $25 \pm 1^{\circ} \mathrm{C}$. A agulha contendo a fibra deve ser introduzida no centro do septo do frasco, e a fibra deve estar posicionada acima do líquido. Aumentar gradualmente a agitação da barra magnética até o máximo da escala do equipamento $(2.000 \mathrm{rpm})$ e, simultaneamente, disparar o cronômetro. Decorrido o tempo necessário para a extração (dez minutos), recolher a fibra para dentro da agulha e retirá-la do frasco. 


\subsubsection{Dessorção dos analitos no injetor}

Iniciar a análise dos analitos com a válvula da purga do split vent fechada e aguardar que a pressão da cabeça da coluna se estabilize. Introduzir rapidamente a agulha no injetor e expor a fibra durante cinco minutos a $250^{\circ} \mathrm{C}$ para realizar a dessorçăo dos analitos. Iniciar a programação de temperatura do cromatógrafo a gás. Manter a fibra exposta dentro do injetor com o split vent aberto com um fluxo de $30 \mathrm{~mL} /$ minuto. Dessa forma, a fibra estará protegida da contaminação do ambiente.

\subsubsection{Procedimento analítico para determinação do grupo BTEX em água residual}

- Pesar 1,0 0,1 grama de cloreto de sódio em um frasco de vidro de $7 \mathrm{~mL}$ com tampa de polietileno com septo de silicone revestido com um filme de teflon e introduzir uma barra magnética no frasco;

- Com uma pipeta volumétrica, transferir uma aliquota de $5 \mathrm{~mL}$ da amostra de água residual para dentro do frasco e fechar rapidamente;

- Transferir o frasco para o banho-maria e fixar com uma garra metálica. Ajustar a temperatura do banho para $25 \pm 1^{\circ} \mathrm{C}$;

- Introduzir a agulha contendo a fibra dentro do frasco por meio do septo e expor a fibra sobre a água;

- Aumentar a velocidade do agitador até que a água se mantenha em agitação constante $(2.000 \mathrm{rpm})$. Manter a fibra exposta durante dez minutos (tempo de extração); 
- Decorrido o tempo de extração, recolher a fibra para dentro da agulha, retirar a agulha do frasco e imediatamente injetar a amostra;

- Após atingir o equilibrio das condições do cromatógrafo (vide item 3.2.1), introduzir a agulha diretamente no injetor split/splitless e realizar a dessorção dos analitos durante cinco minutos. Decorrido esse tempo, abrir o split vent e manter a fibra no injetor para evitar contaminação, até a próxima extração. 


\subsubsection{Validação do método}

\subsubsection{Seletividade}

A seletividade do sistema cromatográfico foi avaliada por meio da verificação da presença de interferentes no tempo de retenção dos analitos. Realizou-se a análise de uma amostra em branco (água do poço) para verificação de interferentes no tempo de retençăo dos compostos do grupo BTEX.

\subsubsection{Linearidade}

A linearidade do método foi calculada utilizando-se uma curva de calibração. Essa curva foi preparada por meio da injeção de cinco concentrações diferentes $(1,5,10,50$ e $100 \mu \mathrm{g} / \mathrm{L})$. A sequeuencia de injeçōes dos padrões deve ser realizada na ordem crescente de concentração dos padrões, para evitar interferência nos resultados. Uma curva de regressão aceitável deve apresentar um coeficiente de correlação $(r)$ maior ou igual a 0,99 .

\subsubsection{Limite de deteç̧ão (LOD) e limite de quantificação (LOQ)}

O limite de deteç̧ão (LOD) foi determinado por meio das injeções de padrões com concentrações conhecidas de benzeno, tolueno, etil benzeno, $p$-xileno, m-xileno e o-xileno. $O$ valor para $O$ LOD foi determinado tomando-se a medida de três vezes o ruído da linha de base.

Realizou-se um estudo de recuperação para determinar o limite de quantificação do método (LOQ) para todos os compostos do grupo BTEX. 
Determinou-se o LOQ por meio da fortificação (adição) dos analitos em água, tendo sido realizado o procedimento analítico nas amostras fortificadas para verificar a eficiência do método na concentração de $5 \mu \mathrm{g} / \mathrm{L}$, pois esse é o limite máximo permitido para benzeno em água potável.

\subsubsection{Estudo de recuperação do método analítico}

Para avaliar a recuperação do método analítico, empregaramse amostras de água fortificadas com solução-padrão do grupo BTEX, como descrito no item 3.2.2, as quais foram submetidas ao procedimento analítico descrito nos itens 3.2.4, 3.2.5 e 3.2.6. Nesse estudo, escolheram-se duas concentrações, $5 \mu \mathrm{g} / \mathrm{L}(\mathrm{LOQ})$ e $80 \mu \mathrm{g} / \mathrm{L}$, com as quais se realizaram sete repetições de fortificações em cada nivel estudado.

Por meio do estudo de recuperação, foram avaliados os seguintes parâmetros: exatidão, precisão e repetibilidade do método analítico.

Analisaram-se amostras de água fortificadas, conforme item 3.2.2, em heptaplicatas (sete determinações), com aliquotas de $5 \mathrm{~mL}$ de água enriquecidas (fortificadas) com solução-padrão do grupo BTEX nas concentrações de $5 \mu \mathrm{g} / \mathrm{L}$ e $80 \mu \mathrm{g} / \mathrm{L}$, como descrito nos itens 3.2.4, 3.2 .5 e 3.2.6. 


\subsection{O sistema de tratamento em estudo}

\subsubsection{Descrição da planta estudada}

Para o desenvolvimento do presente trabalho, selecionou-se uma fábrica de tintas automotivas que possui um processo completo de tratamento de efluentes, com sistemas físico-químico e biológico. Optou-se por essa empresa por ela trabalhar com uma gama ampla de produtos utilizados na indústria automotiva e utilizar produtos do grupo BTEX, que săo propostos para este estudo.

A planta da empresa está sediada em um terreno de aproximadamente $100.000 \mathrm{~m}^{2}$ de área com unidade fabril para produção de insumos automotivos, depósitos de materiais, unidade de suporte, laboratório analítico e de desenvolvimento de produtos, área administrativa e planta para tratamento de efluentes na cidade de São Bernardo do Campo, São Paulo. A empresa tem como portifólio geral a produção de vários tipos de tintas, vernizes, diluentes e complementos automotivos, além de manter uma unidade fabril para produção de polimeros de alta tecnologia.

\subsubsection{Captação do efluente}

O sistema de captação é composto de uma rede em aço carbono protegido por um tratamento químico que evita a açăo corrosiva dos compostos químicos em suas paredes. Todo o resíduo é transferido para um sistema que separa a água dos óleos e excesso de solventes.

Esses resíduos são gerados durante a manufatura de vários produtos, as atividades de laboratórios e a lavagem de equipamentos, como também pelo recebimento das águas dos lavadores de gases e de limpeza de algumas áreas que eventualmente são afetadas por derramamentos. 
Após ser eliminada é transferida para um depósito onde fica estocada até ser tratada.

Para evitar a introdução de solventes junto com a água residual, foi instalado um separador de óleo adicional antes do tanque de estocagem de resíduos a ser tratado. Esse procedimento minimiza a carga de solventes que entra direto no sistema de tratamento de efluentes.

\subsubsection{Tratamento físico-químico}

\subsubsection{Processo de coagulação e floculação}

Esse processo tem como finalidade remover o material particulado em suspensão por meio de tratamento químico prévio. ØDEGAARD (1979) observou que a maioria dos contaminantes presentes nos efluentes são partículas sólidas ou associadas com partículas coloidais muito estáveis. As partículas em suspensão podem variar, com diâmetro de 0,005 a $100 \mu \mathrm{m}\left(5 \times 10^{-9}-10^{-4}\right)$.

O efluente líquido é transferido para o tanque de tratamento físico-químico de $\pm 20 \mathrm{~m}^{3}$ (Figura 3). Nesse momento se realiza o ajuste do $\mathrm{pH}$ utilizando-se adições de ácido sulfúrico, hidróxido de sódio e/ou hidróxido de cálcio. Após atingir a faixa de pH entre 8,5 e 9,0, e sob agitação constante, inicia-se a adição de sulfato de alumínio. Esse processo de adição de substâncias químicas neutraliza as cargas elétricas essenciais para a existência dos colóides, provocando a floculação. 


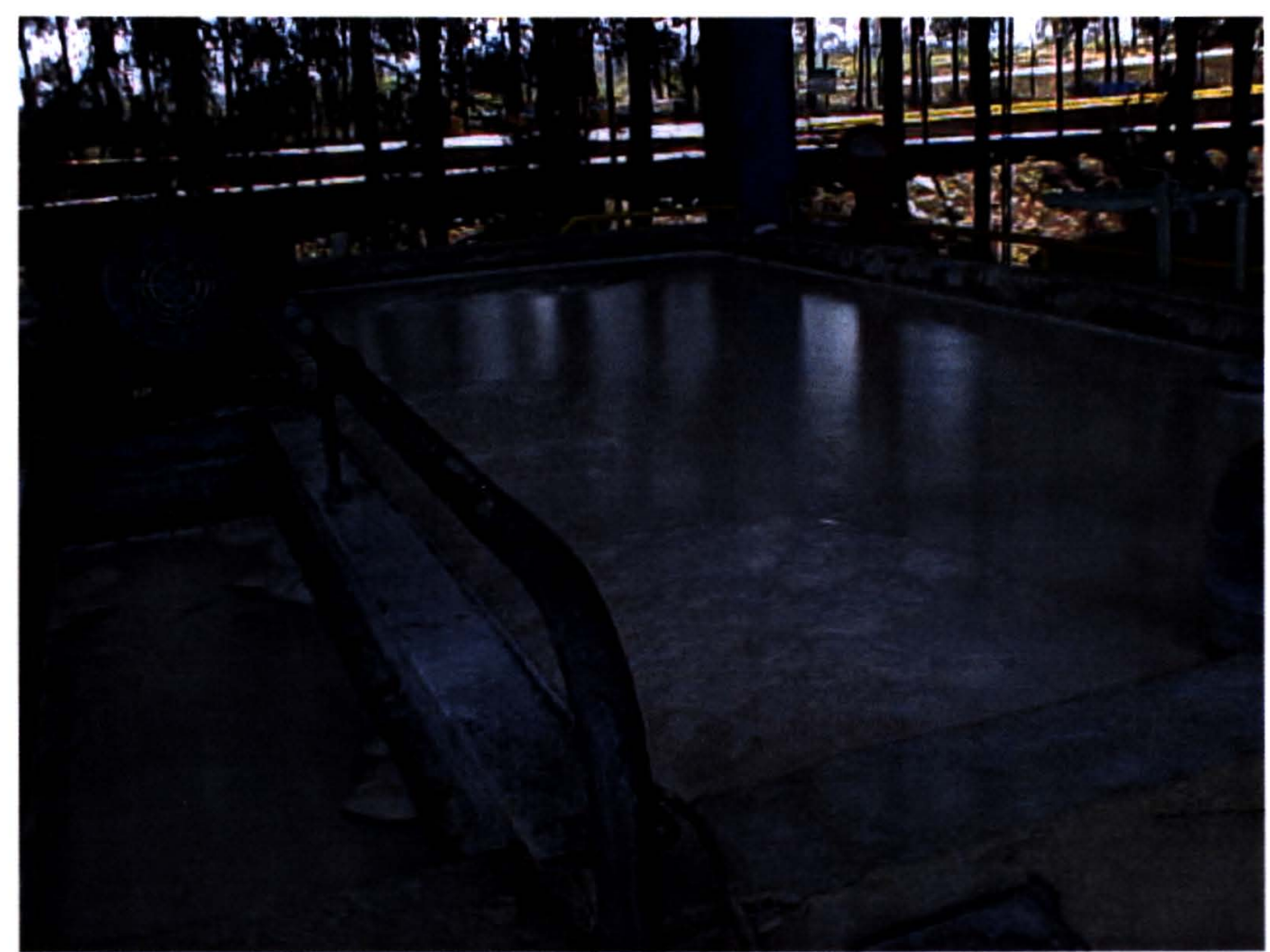

Figura 3 - Tanque de floculação e sedimentação.

Os flocos formados durante a neutralização com hidróxido de sódio são: hidróxido de ferro (III), hidróxido de alumínio, hidróxido de cromo (III), hidróxido de cobre (II), hidróxido de chumbo, hidróxido de zinco, hidróxido de cobalto, hidróxido de níquel, hidróxido de cádmio, hidróxido de manganês, hidróxido de ferro (II), etc. A reação genérica de precipitação é:

$$
\begin{aligned}
& \mathrm{Me}^{3+}+3 \mathrm{Na}^{+} \mathrm{OH}^{-} \longrightarrow \mathrm{Me}(\mathrm{OH})_{3(\mathrm{~s})}+3 \mathrm{Na}^{+} \\
& \mathrm{Me}^{2+}+2 \mathrm{Ca}^{2+}\left(\mathrm{OH}^{-}\right)_{2} \longrightarrow \mathrm{Me}(\mathrm{OH})_{2(\mathrm{~s})}+\mathrm{Ca}^{2+}
\end{aligned}
$$

Durante a adição de hidróxido de sódio, pode haver a formação de complexos com zinco e alumínio, muito solúveis na água. 


$$
\begin{aligned}
& \mathrm{Zn}(\mathrm{OH})_{2}+2 \mathrm{OH}^{-} \longrightarrow\left[\mathrm{Zn}(\mathrm{OH})_{4}\right]^{2-} \\
& \mathrm{Zn}(\mathrm{OH})_{2}+\mathrm{Ca}^{2+}\left(\mathrm{OH}^{-}\right)_{2} \longrightarrow \mathrm{Ca}^{2+}\left[\mathrm{Zn}(\mathrm{OH})_{4}\right]^{2-}
\end{aligned}
$$

O sulfato de alumínio, além de ajudar na floculação, também participa na formação de alguns precipitados insolúveis, como, por exemplo, do sulfato de chumbo, sulfato de cálcio e sulfato de bário.

$$
\begin{array}{ll}
\mathrm{Me}^{2+}+3 \mathrm{SO}_{4}{ }^{2-} & \longrightarrow \mathrm{MeSO}_{4}(\mathrm{~s}) \\
2 \mathrm{Me}^{3+}+3 \mathrm{SO}_{4}{ }^{2-} & \longrightarrow \mathrm{Me}_{2}\left(\mathrm{SO}_{4}\right)_{3(\mathrm{~s})}
\end{array}
$$

Quando se necessita acelerar a floculação dos agentes sólidos na água, adiciona-se ao sistema um polímero orgânico, que acelera a floculação num periodo de quatro a seis horas. Esse artifício é utilizado quando a demanda de efluente é muito grande e ultrapassa a capacidade de estocagem de água residual a ser tratada. Em alguns tipos de efluentes em que pode haver espécies químicas com potencial de oxi-redução, é necessário realizar um tratamento químico com um oxidante; por exemplo, o peróxido de hidrogênio.

$\mathrm{Na}$ figura 4, observa-se uma amostra de água residual obtida no reservatório de resíduos que será tratada pela técnica de tratamento fisico-químico. A água contaminada com a suspensão de matéria orgânica e inorgânica (resíduos de resinas, cargas minerais e resíduo de tinta removida dos tanques da produção com solução alcalina) é submetida ao tratamento físico-químico por meio do ajuste de pH entre 8,5 e 9,0 e com adição de sulfato de alumínio e hidróxido de cálcio. As pequenas partículas coloidais presentes iniciam um processo de aglomeração, formando, assim, partículas maiores até atingir um tamanho suficiente para iniciar o processo de precipitação. O processo de precipitação normalmente se completa após 
quatro a cinco horas após o tratamento, ou seja, até que todo o resíduo em suspensão seja floculado e sedimentado.

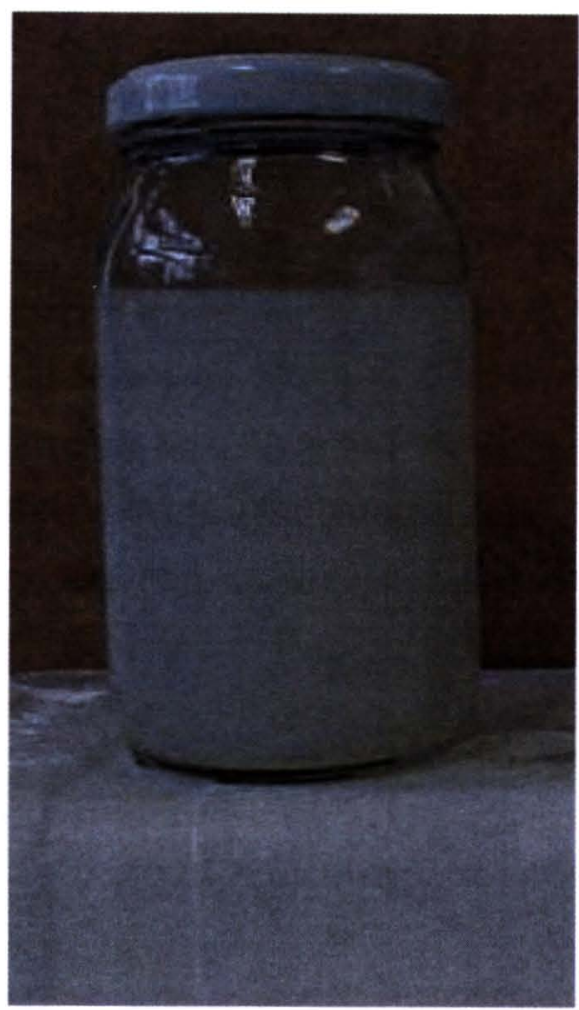

Figura 4 - Amostra de água após ser coletada no reservatório de água a ser tratada.

\subsubsection{0 processo de sedimentação ou flotação}

O processo de sedimentação permite que os flocos formados sejam depositados no fundo do tanque, reduzindo-se a concentração de partículas sólidas em suspensão. A flotação é uma alternativa de sedimentação e tem vantagens quando os flocos são muito pequenos (WHO, 1996). Os fatores que influenciam a sedimentação incluem: tamanho, formato, peso do floco formado, viscosidade e temperatura da água. 
Após homogeneizar-se durante duas horas, o líquido turvo é deixado em repouso durante quatro a cinco horas, promovendo-se a decantação das partículas sólidas. Durante o processo de formação dos flocos, também é importante mencionar o processo de co-precipitação, que arrasta partículas sólidas e ajuda a precipitar íons mais solúveis. Completado o processo de decantação, o líquido limpo é drenado para um reservatório para futura filtração.

Sobre o resíduo já tratado inicialmente, adiciona-se mais efluente líquido para tratamento, repetindo-se o processo de ajuste de $\mathrm{pH}$ e adição do floculante. Esse processo se repete por mais três ou quatro vezes, de forma que o processo de floculação obtenha uma partícula floculada de um tamanho adequado, que não irá entupir a tubulação ou dificultar sua filtração.

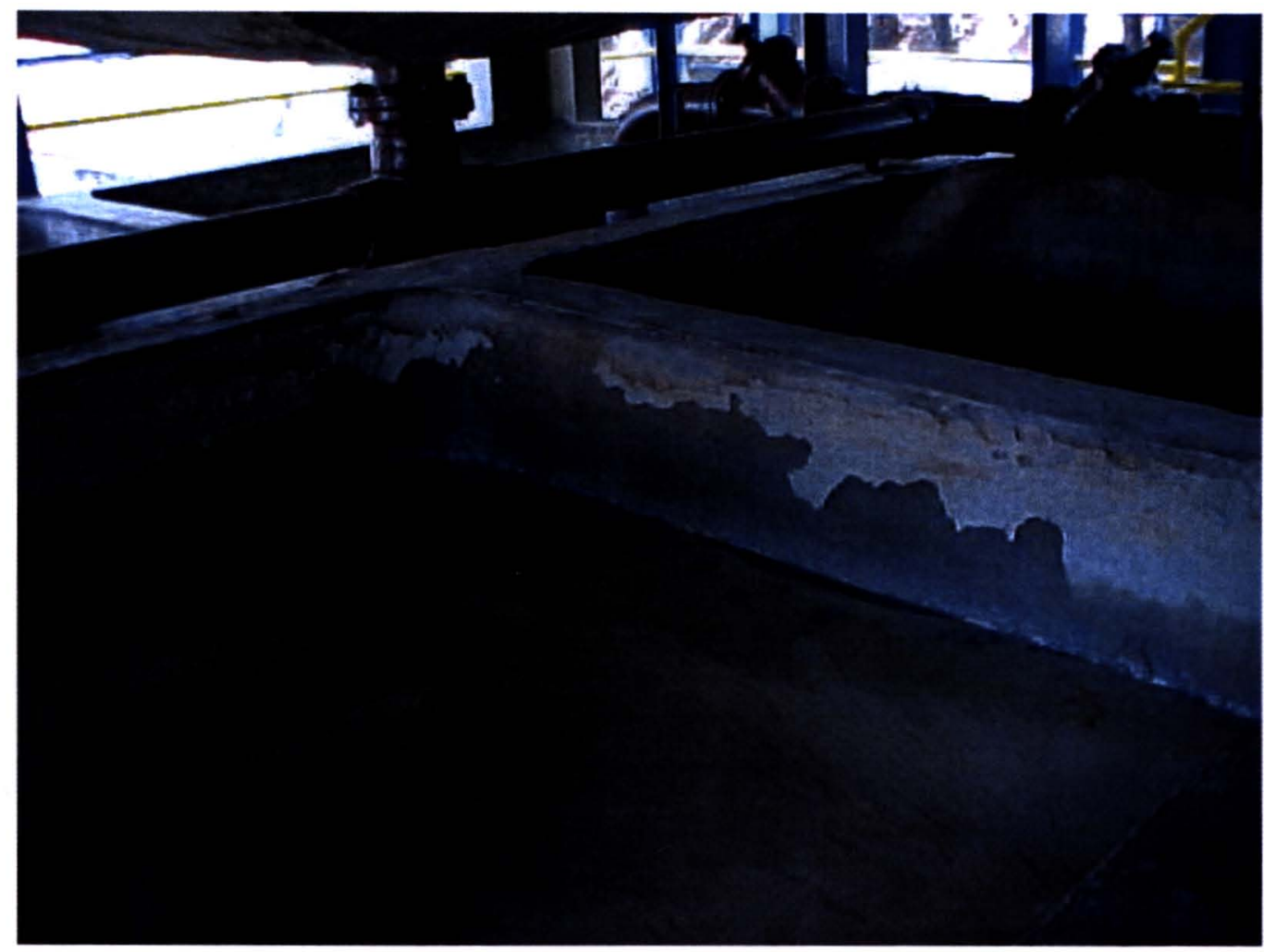

Figura 5 -Decantadores secundários. 
O resíduo sólido em suspensão é então transferido para os decantadores secundários, que são constituídos de quatro tanques de $5 \mathrm{~m}^{3}$ cada (Figura 5), onde permanece durante um a dois meses sofrendo 0 processo de maturação do precipitado, de forma que as partículas se aglutinem formando partículas muito maiores e sedimentem. Esse processo favorece a filtração no filtro prensa.

$\mathrm{Na}$ figura 6, observa-se a mesma amostra de água residual obtida no tanque de estocagem após receber o tratamento físico-químico. $O$ processo de remoção da suspensão é muito eficiente, provocando a total decantação do resíduo em suspensão. Em alguns casos, os resíduos em suspensão, por serem muito leves, necessitam de maior tempo de descanso para formar flocos maiores e decantar.

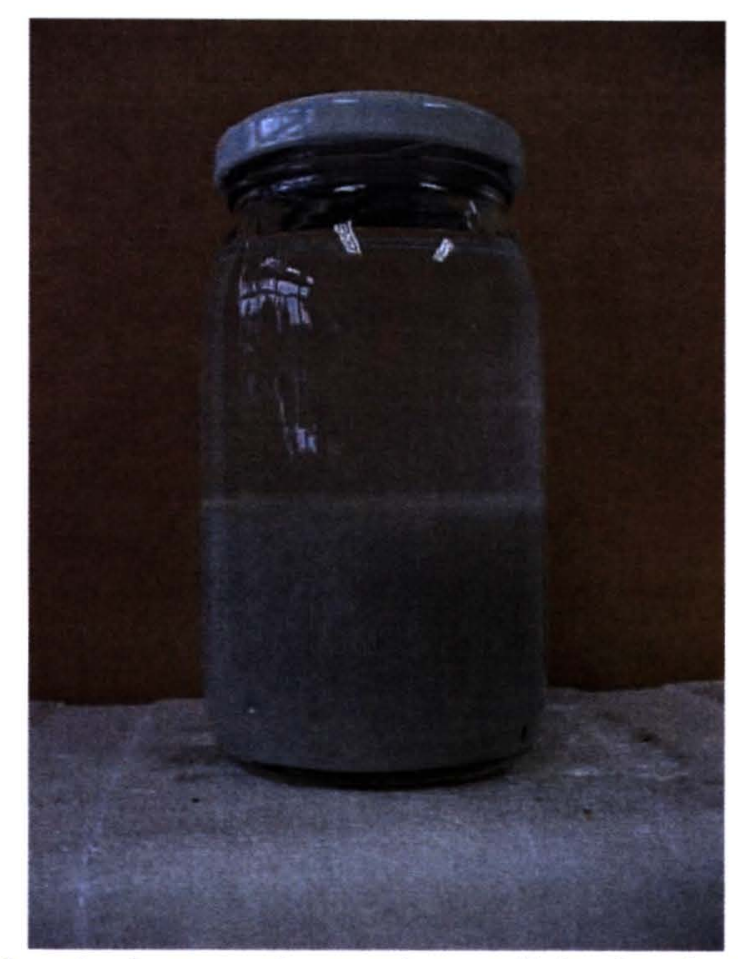

Figura 6 - Amostra da água após receber sulfato de alumínio, hidróxido de cálcio e ajuste de pH. Após 4 horas em repouso. 


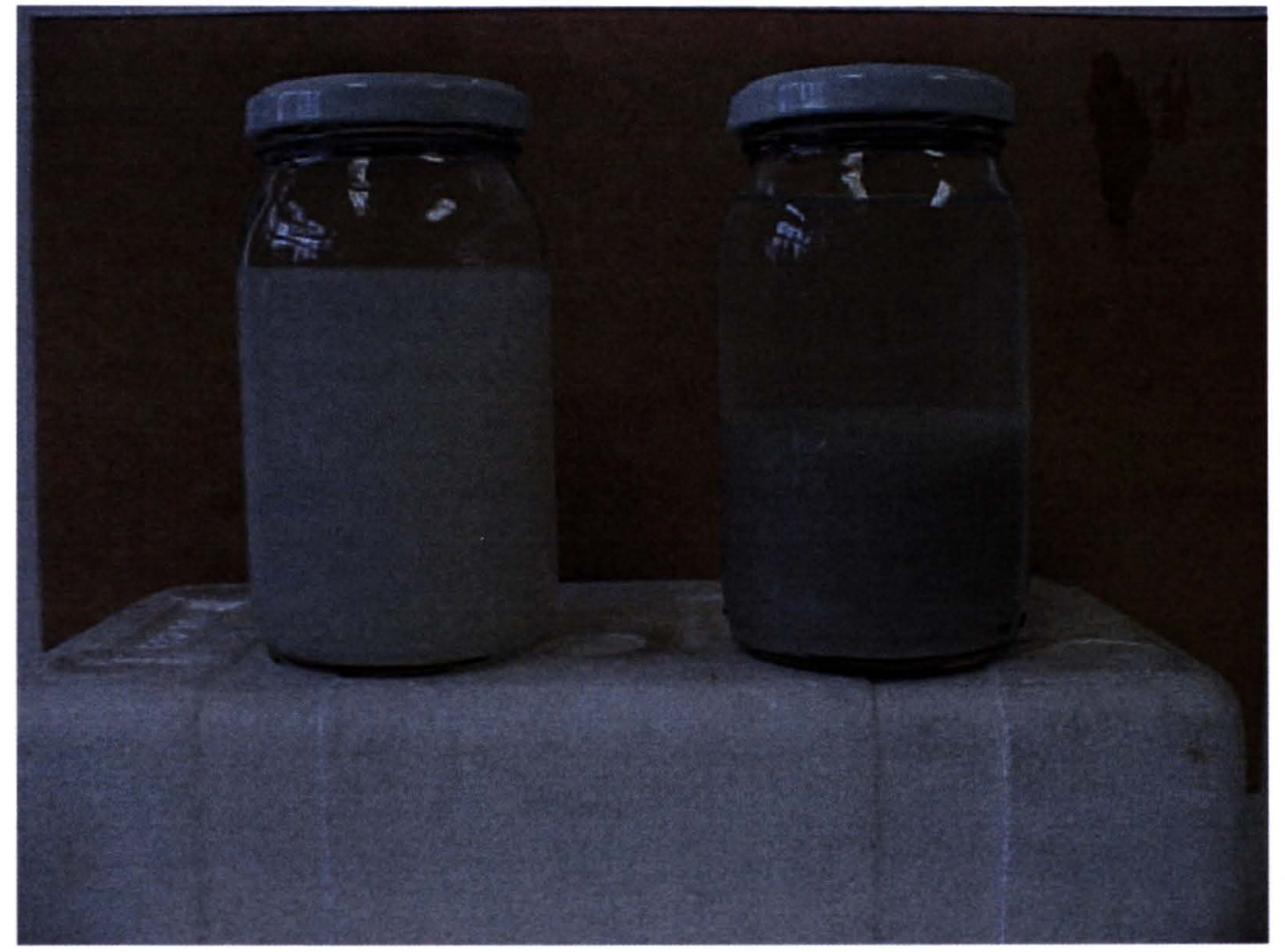

Figura 7 - Amostras antes (esquerda) e depois (direita) do tratamento físicoquímico.

$\mathrm{Na}$ figura 7, vêem-se as duas amostras, lado a lado, antes e depois do tratamento. No lado esquerdo, está a amostra antes do tratamento e, no direito, a amostra após o tratamento físico-químico.

\subsubsection{Filtração}

Durante o processo de filtração, partículas residuais dos flocos não removidos durante a sedimentação são eliminadas. O sistema de filtração em leito contínuo por brita e areia (Figura 8) é limitado, por entupir o leito rapidamente e necessitar de manutenções periódicas. 


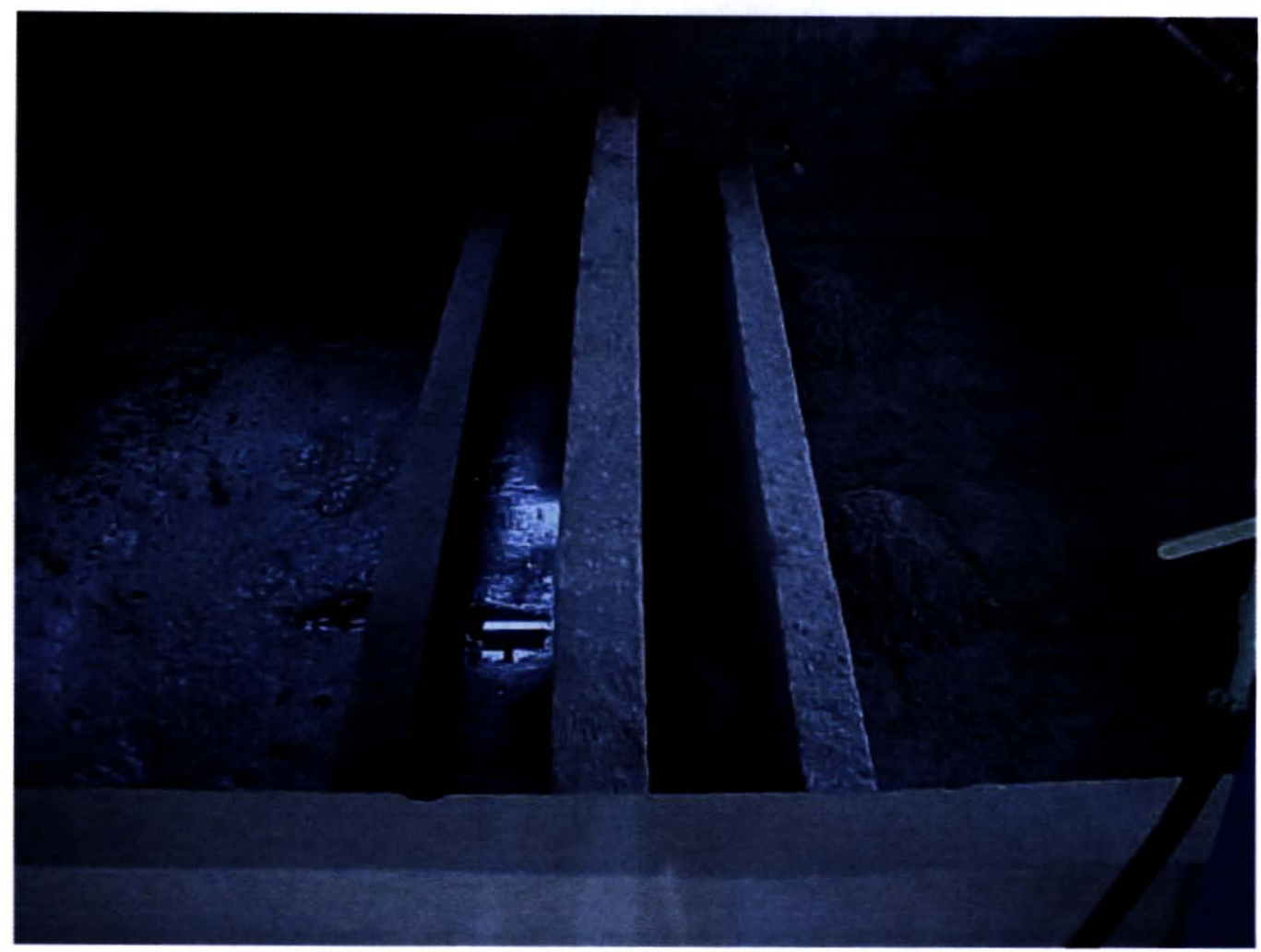

Figura 8 - Tanque de filtração de leito contínuo com brita e areia.

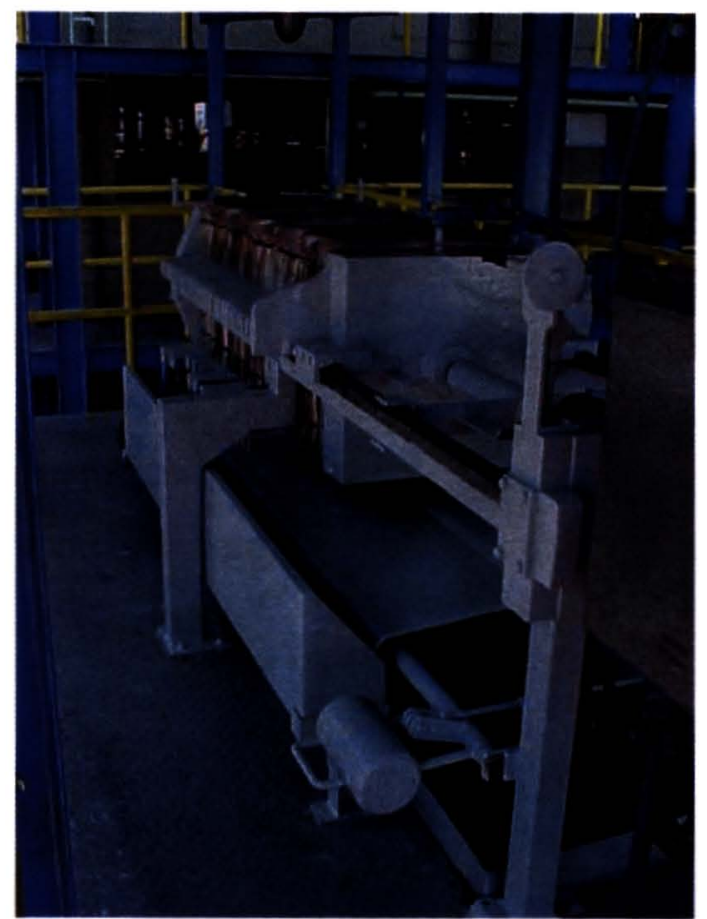

Figura 9A - Sistema de filtração do tipo filtro prensa. 


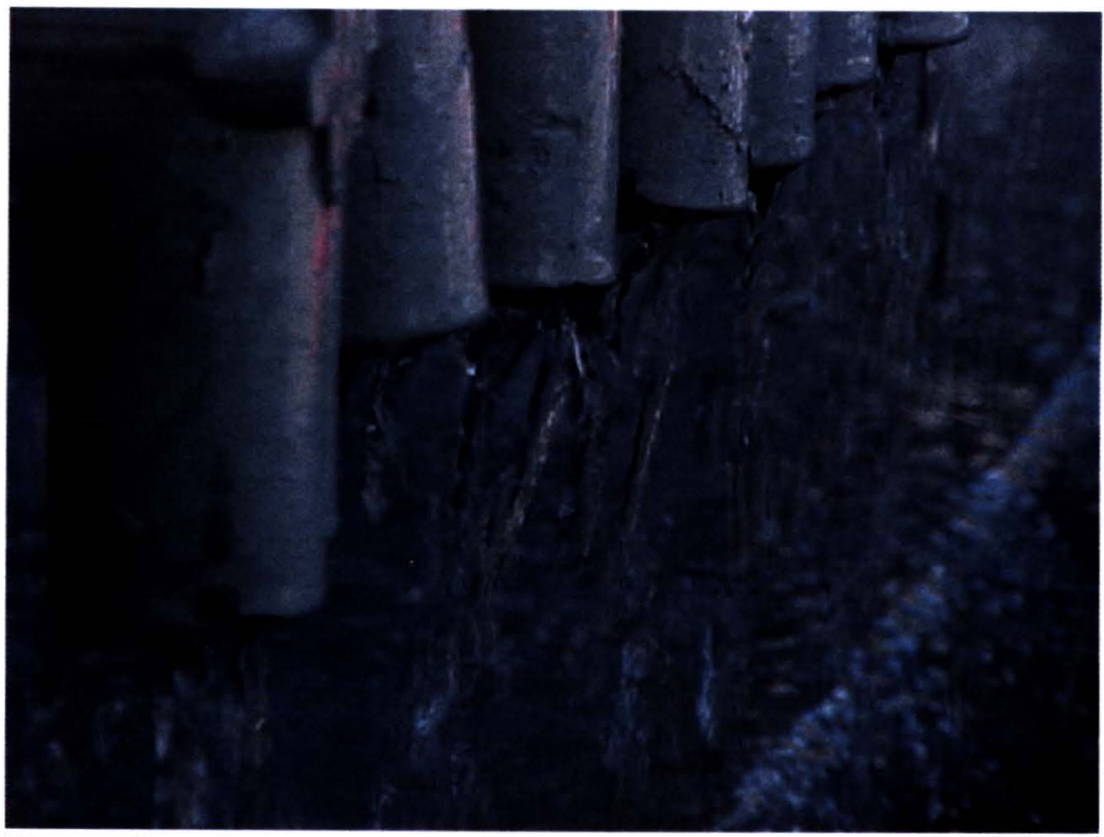

Figura 9B - Saída do sistema de filtro prensa.

Para resíduos mais finos, é necessário utilizar um filtro do tipo prensa (Figuras 9A e 9B), que elimina todas as partículas em suspensão, além de proporcionar uma desidratação maior da torta de filtração.

Decorrido o tempo de sedimentação, a água sobrenadante é drenada e transferida para o sistema de filtragem por leito contínuo. Nesse estágio, o resíduo sedimentado restante é transferido por uma bomba e filtrado por um filtro do tipo prensa. A água límpida é transferida para um reservatório e reservada. Após a filtração, o resíduo sólido é acondicionado em tambores e posteriormente incinerado. Na figura 10, observa-se o esquema completo do sistema de tratamento físico-químico. 


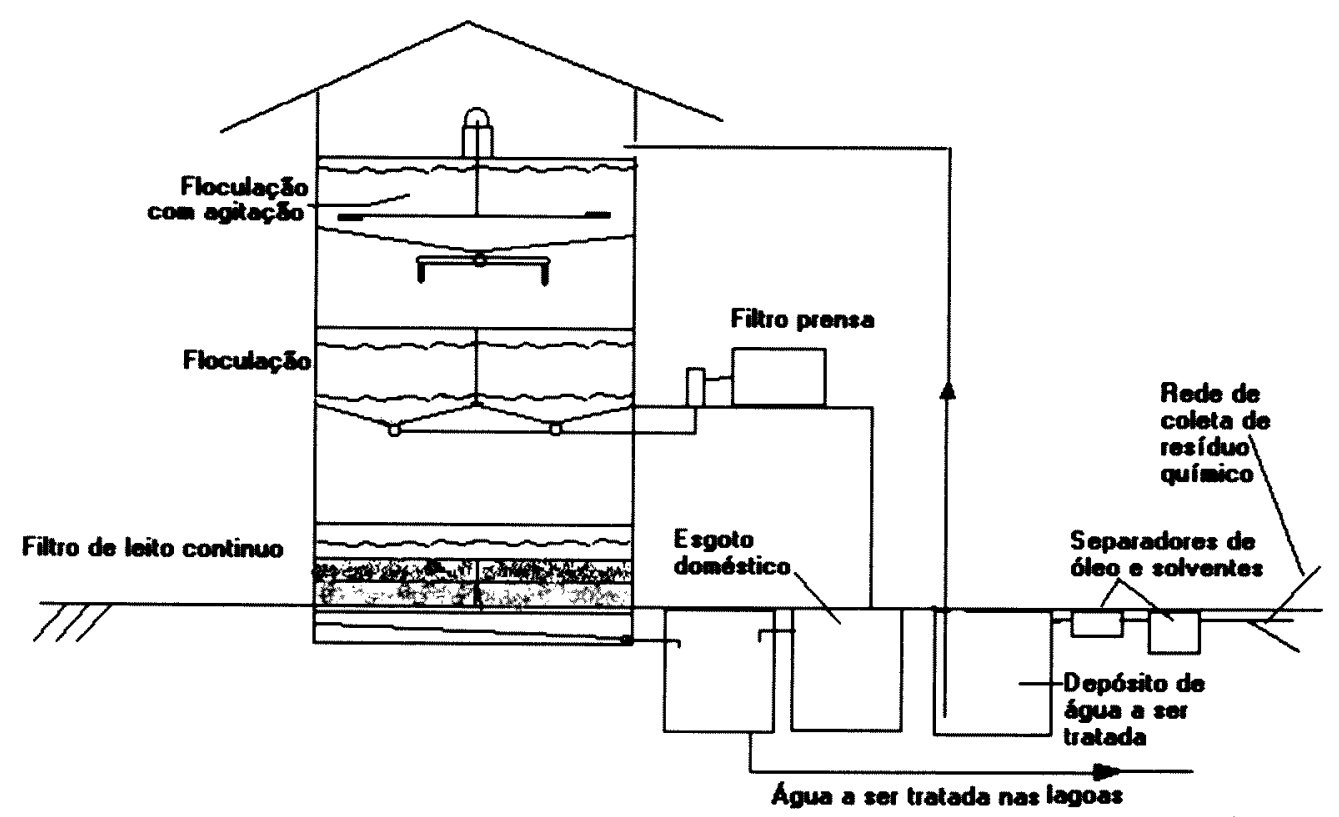

Figura 10 - Esquema completo do sistema de tratamento físico-químico.

\subsubsection{Tratamento biológico}

Esse método consiste em decompor a matéria orgânica dispersa (coloidal) e a matéria orgânica dissolvidas na água, por meio do metabolismo aeróbio dos microorganismos. VOZNAYA (1981) observou que os sistemas de tratamento biológico dependem dos seguintes fatores:

1) da suscetibilidade da substância contida no esgoto ou efluente à oxidação bioquímica;

2) da presença de nutrientes necessários, como nitrogênio, fosfatos, potássio, carbono, vitaminas e micronutrientes;

3) da concentração dos poluentes que não exceda os limites especificados;

4) do $\mathrm{pH}$ próximo à neutralidade;

5) de não se excederem as concentrações máximas de substâncias tóxicas que podem causar a morte dos microorganismos; 
6) de o esgoto estar livre de substâncias com superfície ativada, que possam interferir no contato entre líquido e oxigênio do ar.

Normalmente, para os efluentes industriais, os requisitos acima não podem ser aplicados diretamente, devendo ocorrer um pré-tratamento especial.

\subsubsection{Tratamento com lodo ativado (tanque de equalização)}

O processo com lodo ativado baseia-se na oxidação da matéria orgânica em condições aeróbicas, sendo as substâncias orgânicas decompostas em $\mathrm{CO}_{2}$ por meio de microorganismos.

A água residual tratada pelo sistema físico-químico é misturada com a água do esgoto doméstico na proporção de 30/70 e transferida para o tanque de equalização de mais ou menos $50 \mathrm{~m}^{3}$ (Figura 11), localizado na área conhecida como lagoa de tratamento biológico.

Nesse estágio, não se adiciona mais nenhum tipo de produto quimico, realizando-se somente a biodegradação biológica por meio da aeração com ar comprimido com os microorganismos presentes no tanque. A cor da água desse tanque é escura, pois é rica em biomassa e biolodo. A cada 30 minutos, realiza-se a transferência de 5.000 litros de água para a lagoa seguinte, de $2.000 \mathrm{~m}^{3}$. Concluída a transferência, o sistema automático repõe os 5.000 litros com água a ser tratada proveniente do tratamento fisico-químico. 


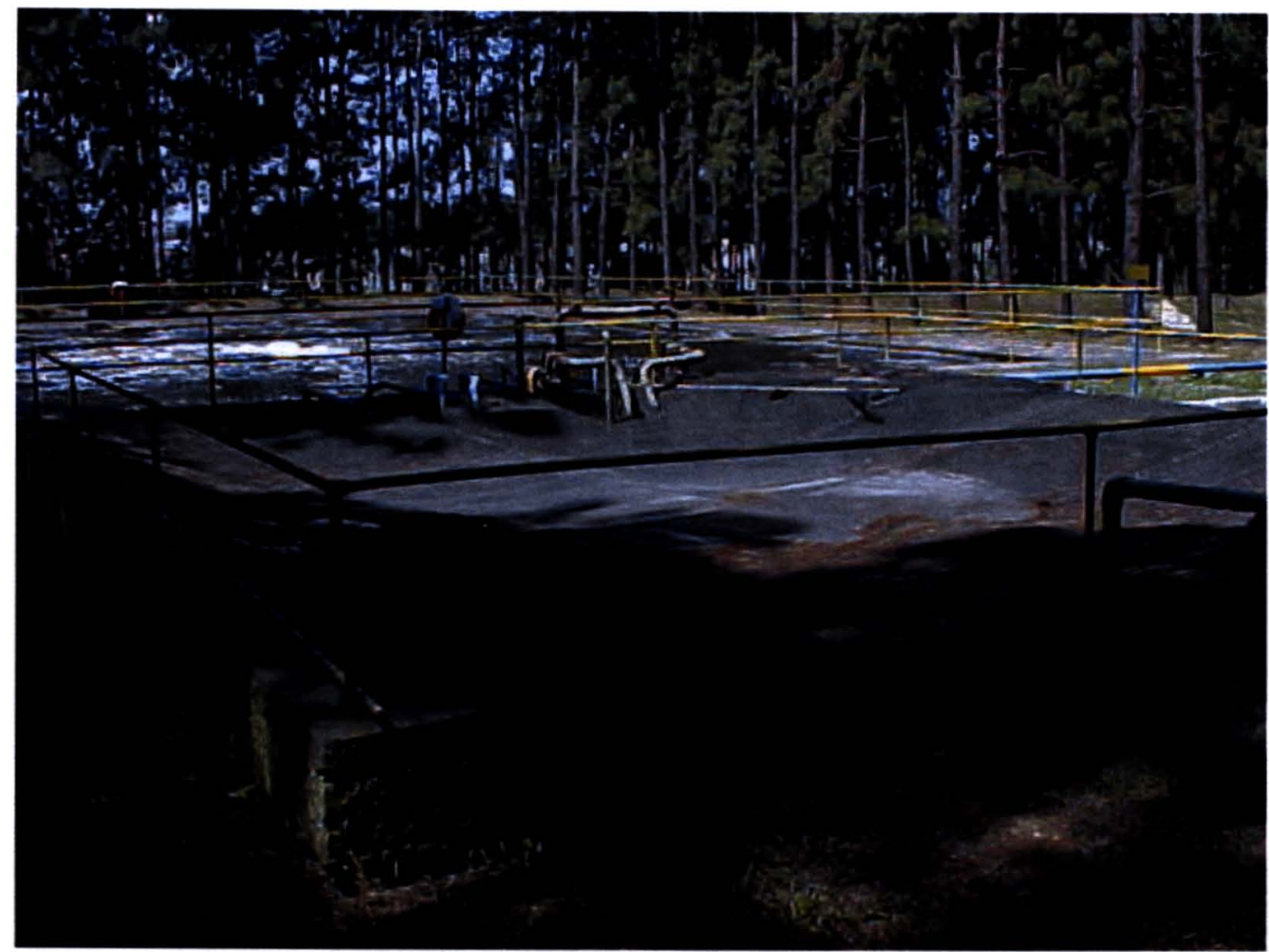

Figura 11 - Tanque de equalização (presença de lodo ativado).

\subsubsection{Lagoas de estabilização}

Nas lagoas de estabilização, o processo de decomposição das substâncias também se baseia na oxidação biológica por meio de microorganismos. Nesse estágio, o tempo de permanência das substâncias é muito maior e possibilita que os microorganismos degradem as substâncias mais complexas (figura 12).

Nesse estágio, como no anterior, não se adiciona nenhum produto químico ou nutriente, e as substâncias orgânicas presentes continuam sendo metabolizadas pelos microorganismos presentes na água, com intensa aeração. A cor da água é menos turva que a anterior, mas ela ainda contém grande quantidade de lodo ativado. Ao contrário da lagoa de equalização, esta deixa o excesso de água ser lentamente transferido, por 
gravidade, para a lagoa seguinte. Nessa lagoa, há um sistema que evita que o lodo passe para o tanque seguinte.

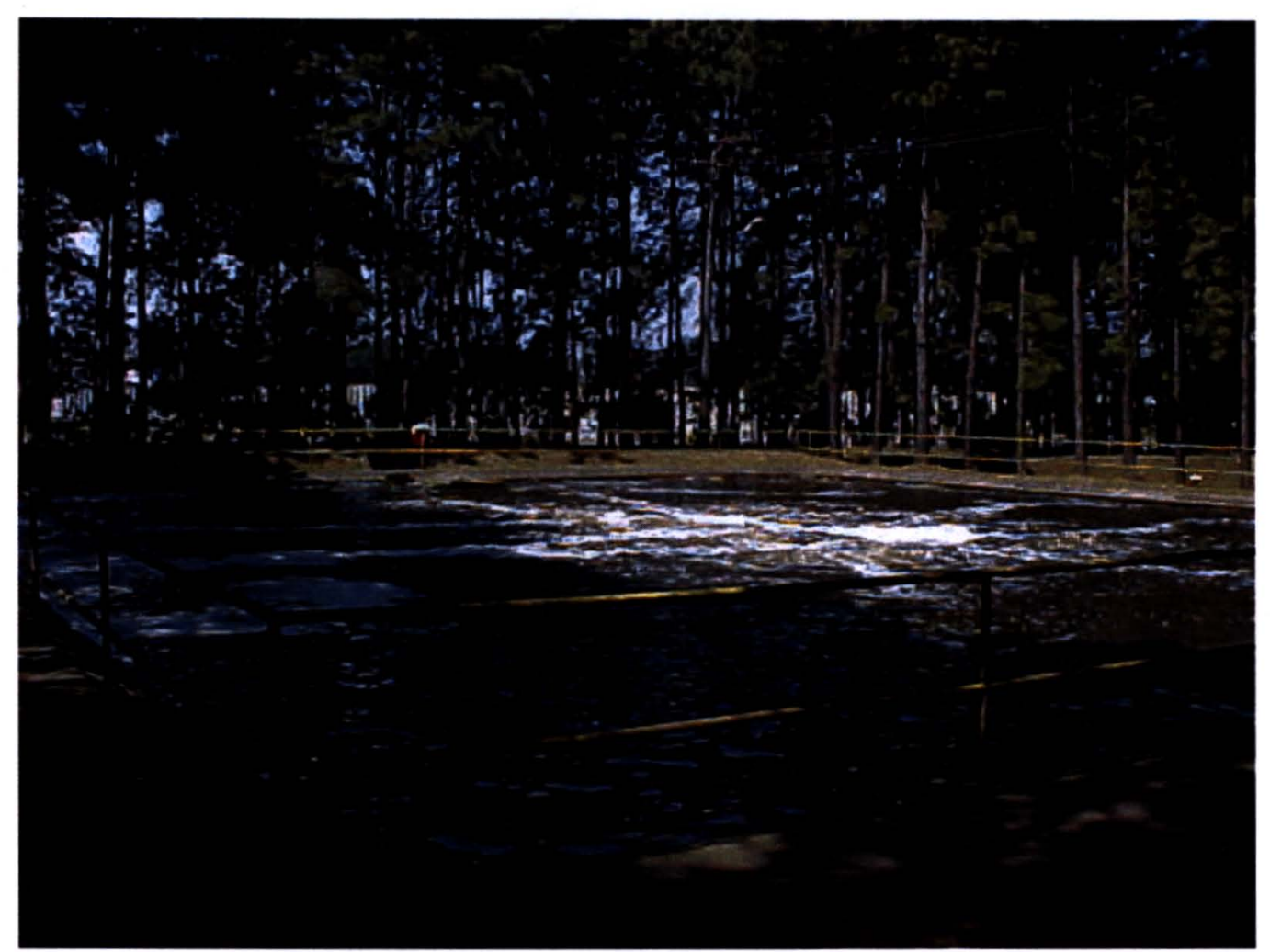

Figura 12 - Lagoa de estabilização 1 (presença de lodo ativado).

Na terceira lagoa, já há peixes do tipo carpa e tilápia do Nilo, e observa-se que a cor da água já é bem menos turva do que nos estágios anteriores e também apresenta grande quantidade de algas. $O$ sistema permanece constantemente aerado com ar comprimido, que promove uma forte agitação. Esse tanque tem aproximadamente $3.000 \mathrm{~m}^{3}$ (Figura 13) e apresenta uma área pequena chamada separador, onde se encontra instalado um sistema que transfere o excesso de lodo para um tanque coletor, por intermédio do fluxo constante de ar e do líquido. 


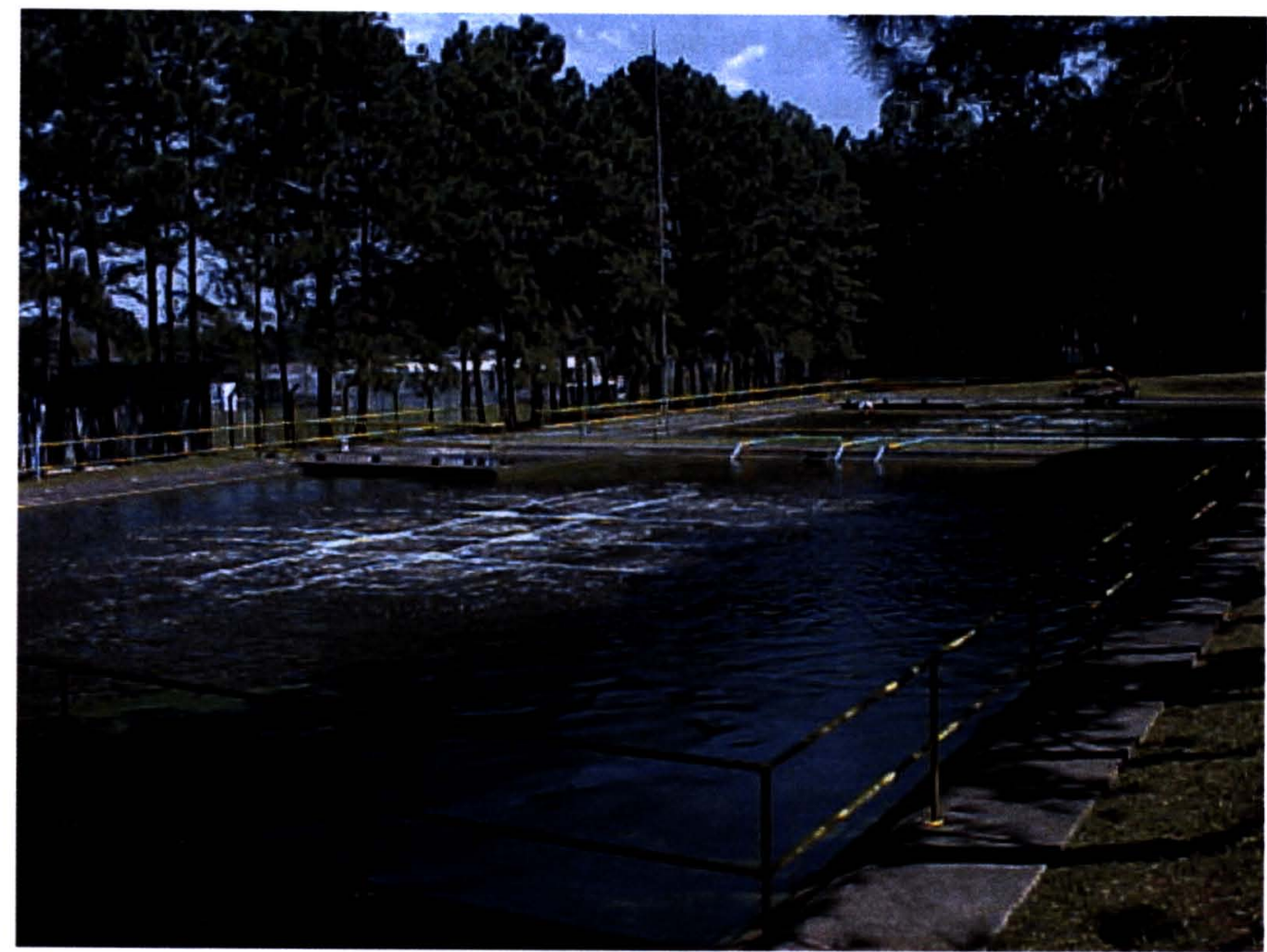

Figura 13 - Lagoa de estabilização 2.

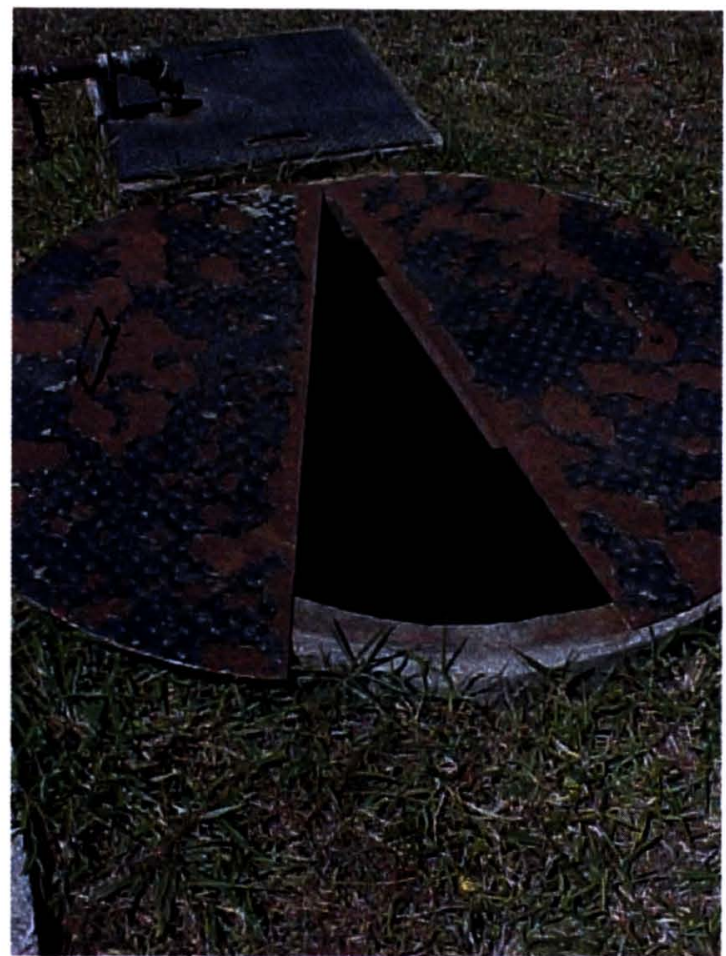

Figura 14 - Sistema coletor do separador de resíduo sólido (biolodo). 
O resíduo sólido deposita-se no fundo e a água retorna para o tanque separador. A água é transferida para o quarto tanque por gravidade. O resíduo depositado no coletor do separador (Figura14) é retirado semanalmente e enviado para incineração.

$\mathrm{Na}$ última lagoa, a água sofre intensa aeração com ar comprimido, acelerando-se a ação dos microorganismos presentes. Observa-se também um aumento da quantidade de algas de coloração verde e um maior número de carpas. Nessa lagoa, a água é levemente turva, com uma coloração escura.

O volume do tanque é praticamente o mesmo do anterior, de $3.000 \mathrm{~m}^{3}$ (Figura 15), e o sistema separador de resíduo sólido são idênticos. Em todos os tanques, o fundo é de concreto e tratado com produto impermeabilizante. O resíduo sólido separado é retirado quinzenalmente e incinerado.

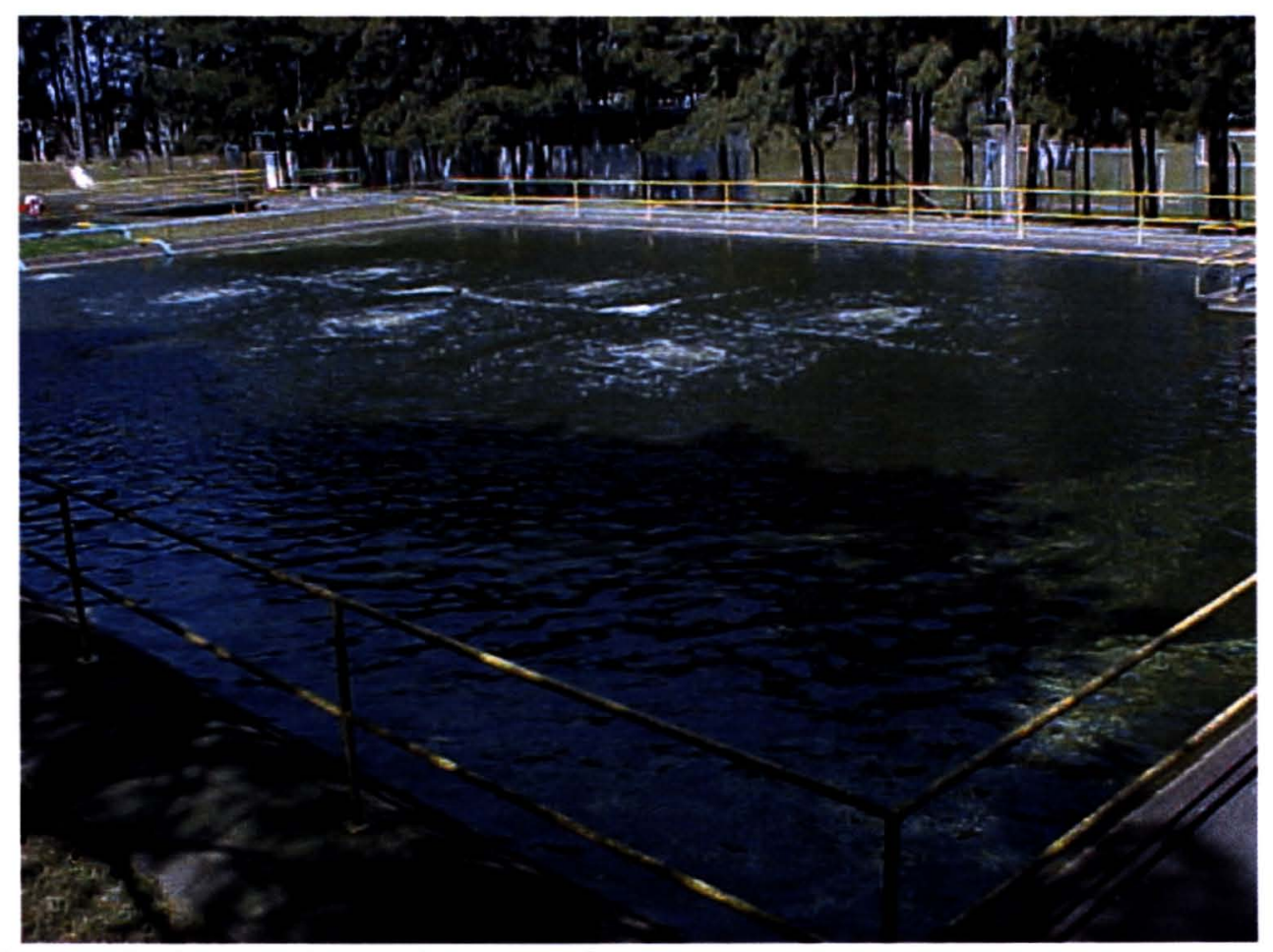

Figura 15 - Lagoa de estabilização 3. 
Nesse estágio, a água tratada é transferida para um tanque reservatório e distribuída em uma área de $2000 \mathrm{~m}^{2}$ ao campo de futebol, com vegetação rasteira. Na saída do reservatório, mede-se o volume diário de 40 a $50 \mathrm{~m}^{3}$ de água tratada a cada 24 horas, e a água em tratamento permanece no sistema aproximadamente durante 30 dias, antes de ser eliminada no meio ambiente.

O sistema trata aproximadamente $1.200 \mathrm{~m}^{3}$ de água mensalmente. Essa água, após ser distribuida sobre o solo, continua sofrendo a ação dos microorganismos do solo até migrar para a parte mais baixa do terreno e ser despejada no córrego. Na figura 16, observa-se o esquema geral do sistema de tratamento biológico e, na figura 17,0 esquema geral de todo o processo.

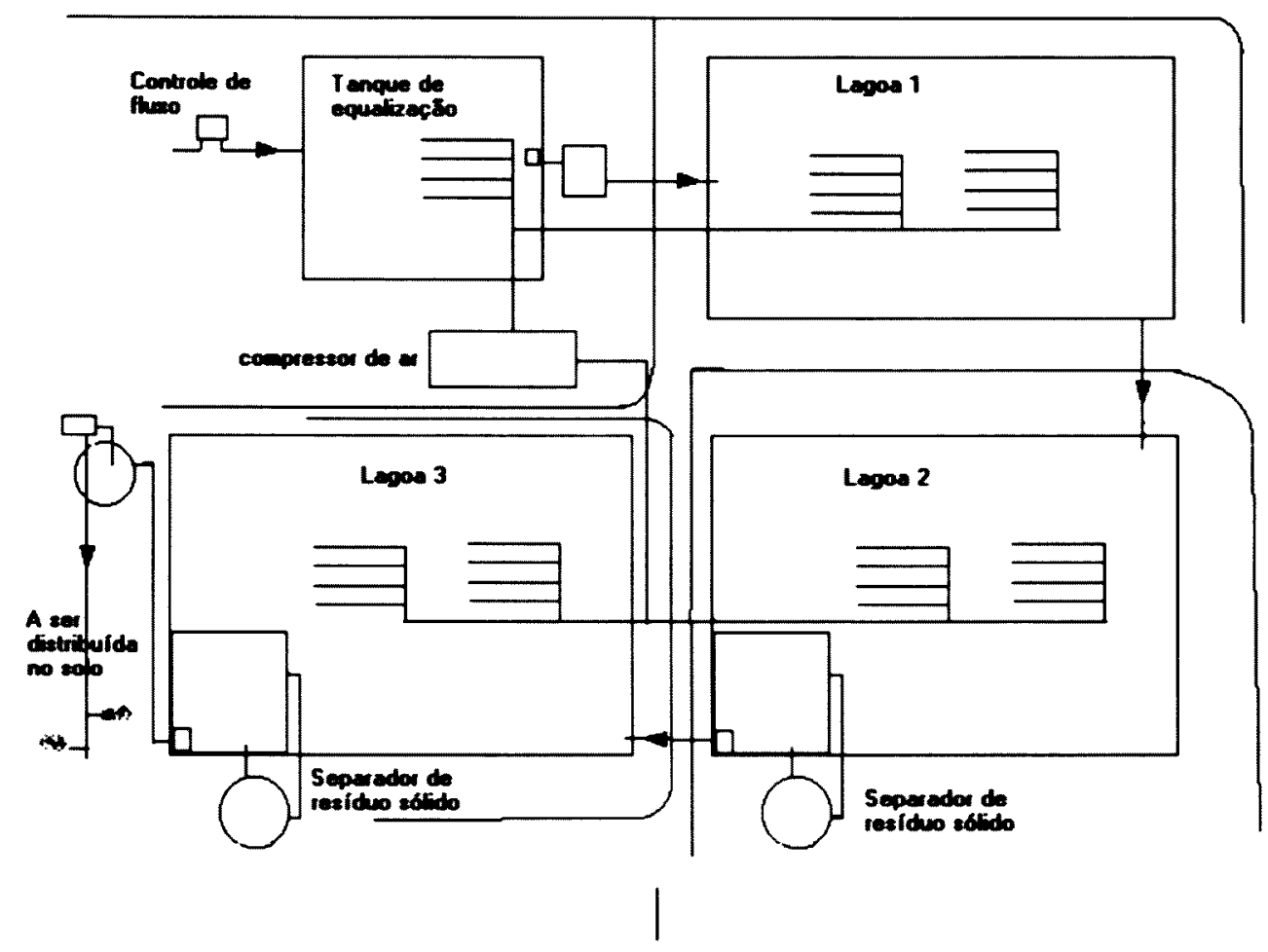

Figura 16 - Esquema do sistema de tratamento biológico. 


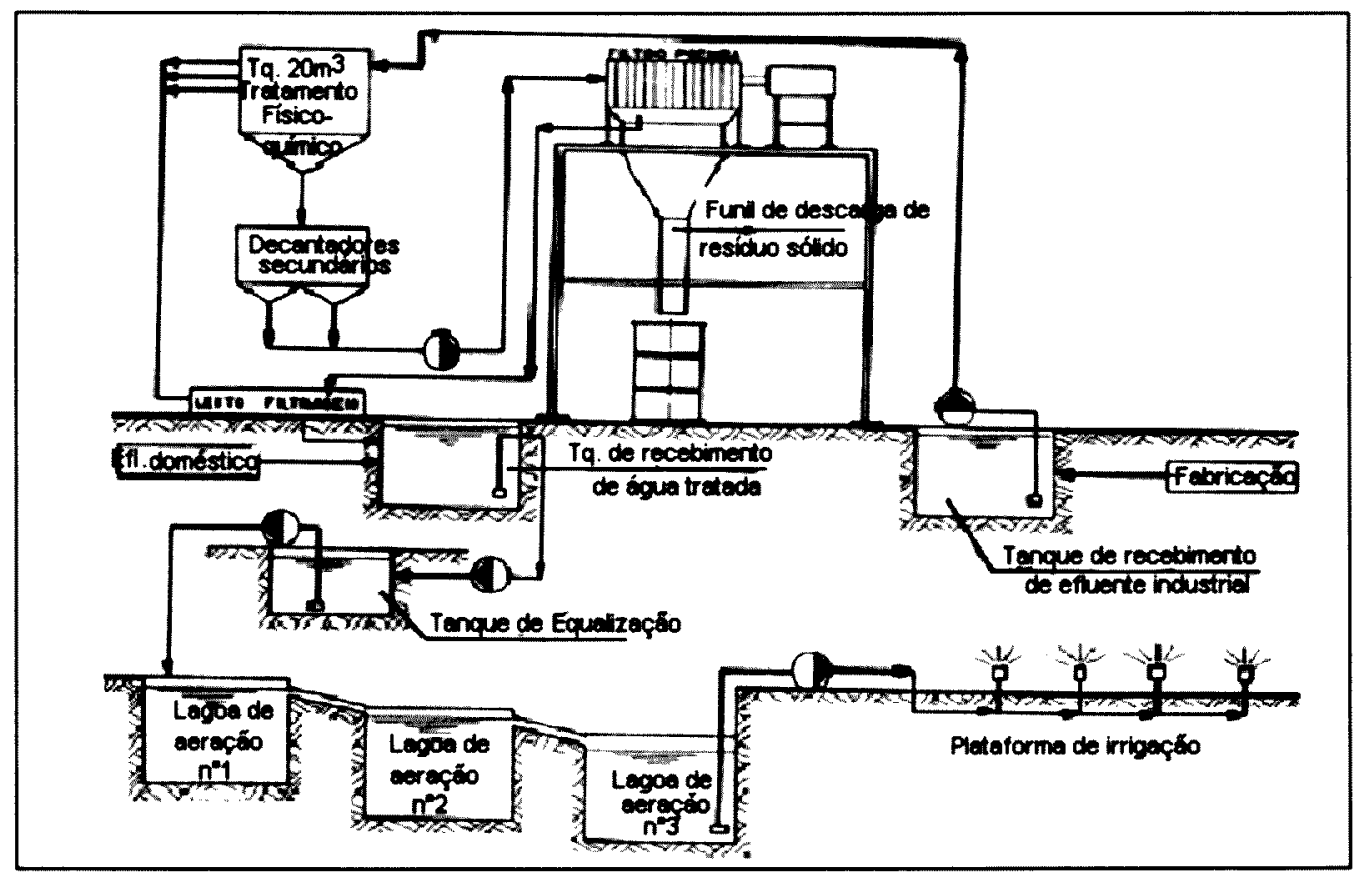

Figura 17 - Esquema do sistema completo de tratamento de efluentes. 


\section{RESULTADOS E DISCUSSÕES}

\subsection{Resultados e discussões da otimização do método analítico}

\subsubsection{Otimização do método cromatográfico}

A otimização das condições analíticas foi desenvolvida por meio de vários experimentos. Para isso, utilizou-se uma solução-padrão contendo $100 \mu \mathrm{g} / \mathrm{L}$ de uma mistura do grupo BTEX. Nesse estudo, utilizouse um cromatógrafo a gás da Hewlett Packard, modelo 6890/Plus, com injetor split/splitless e detector de ionização de chama (DIC).

O primeiro passo no sentido da otimização analítica foi a escolha da coluna cromatográfica. Identificaram-se na literatura diferentes tipos de colunas empacotadas e capilares, utilizadas para a determinação do grupo BTEX. Entretanto, as colunas capilares são mais adequadas na determinação do BTEX por possibilitarem maior eficiência na separação dos analitos e sensibilidade do método. Dessa forma, optou-se inicialmente por trabalhar com uma coluna capilar de sílica fundida, com $25 \mathrm{~m}$ de comprimento, recoberta internamente com um filme de $0,25 \mathrm{~mm}$ de diâmetro e $0,5 \mu$ de filme de polidimetil siloxano (HP-1). Entretanto, observou-se baixa eficiência na separação dos compostos p-xileno e etil benzeno, pois eles eluiam no mesmo tempo de retenção (Figura 18).

Do ponto de vista analítico, deve-se considerar a necessidade de separar o p-xileno do etil benzeno para avaliarem-se corretamente as concentrações dos compostos nas amostras. Colunas polares permitem tal separação, com melhora significativa da eficiência na separação dos isômeros de xileno e etil benzeno. Para isso, utilizou-se uma coluna capilar de sílica fundida, com $60 \mathrm{~m}$ de comprimento, recoberta internamente com um filme de $0,5 \mu$ de polietileno glicol crosslinked, com $0,32 \mathrm{~mm}$ de diâmetro 
externo (HP-INNOWAX). As condições de otimização do detector foram obtidas por meio do ajuste do fluxo de gases (hidrogênio e ar sintético), de forma a obter-se o maior nível de energia do sinal eletrônico e, conseqüentemente, o máximo de sensibilidade do detector.

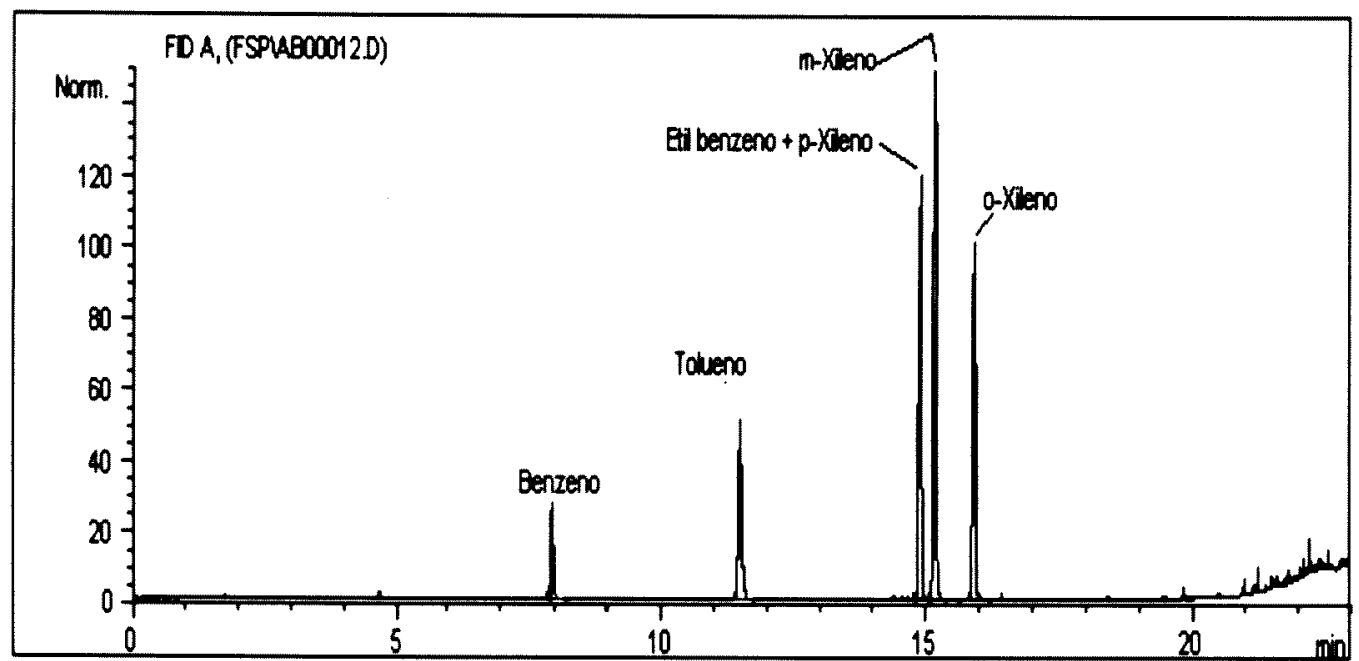

Figura 18 - Cromatograma do grupo BTEX na concentração de $100 \mu \mathrm{g} / \mathrm{L}$ de cada componente, utilizado para a otimização do método analítico na coluna HP-1.

Outro ponto crítico da etapa da padronização analítica foi a escolha das condições iniciais do método. Por meio de injeções sucessivas do padrão, realizaram-se várias alterações nos parâmetros analíticos, tais como: fluxo de gás de arraste, temperatura e alterações nas rampas de aquecimento, até obter-se o cromatograma ideal com o máximo de separação entre os isômeros de xileno (Figura 19). Durante o estudo com uma amostra real do sistema de tratamento de efluente, observou-se inicialmente que havia a co-eluição de uma substância não identificada junto com o pico do tolueno e uma outra com o $m$-xileno. 


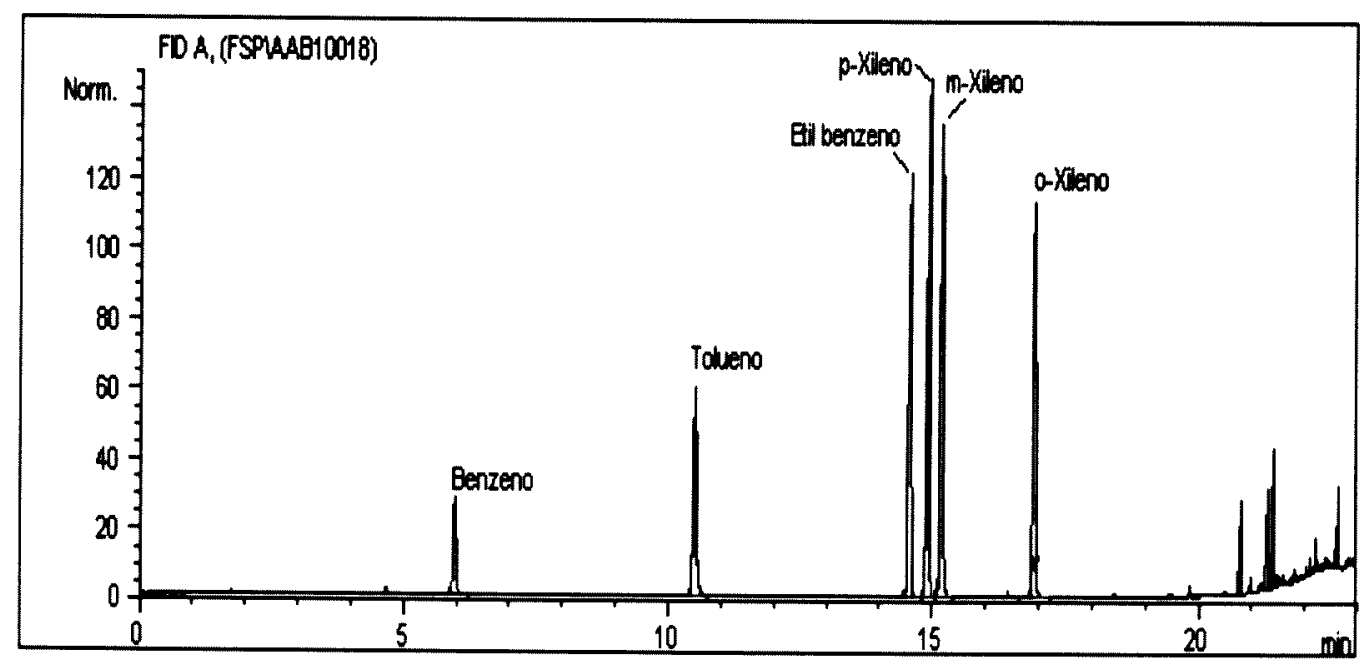

Figura 19 - Cromatograma do grupo BTEX na concentração de $100 \mu \mathrm{g} / \mathrm{L}$ de cada componente, utilizado para a otimização do método analítico na coluna (HP-INNOWAX).

Esse problema foi solucionado por meio da alteração de alguns parâmetros analíticos, tais como: mudança da rampa de aquecimento e do fluxo de gás de arraste, até obter-se uma separação satisfatória entre os componentes com problema de co-eluição. Vários testes analíticos foram simulados até obterem-se as novas condições analíticas ideais para análise. As novas condições analíticas foram: isoterma de $40^{\circ} \mathrm{C}$ durante nove minutos, uma rampa de $5^{\circ} \mathrm{C} /$ minuto até atingir $100^{\circ} \mathrm{C}$, uma isoterma de um minuto nessa temperatura e uma segunda rampa de $40^{\circ} \mathrm{C}$ até $250^{\circ} \mathrm{C}$, para limpeza da coluna e fluxo de $2,9 \mathrm{~mL}$ por minuto.

Para obter-se o máximo de sensibilidade do método de extração com a fibra SPME, foi necessário otimizar o sistema de injeção, ou seja, operar o sistema no módulo splitless. Para isso, trocou-se o liner de vidro de $2 \mathrm{~mm}$ de diâmetro interno por um de $0,7 \mathrm{~mm}$ de diâmetro. Essa troca proporcionou a diminuição da dispersão dos analitos dentro do injetor $e$, conseqüentemente, melhorou o nivel de sensibilidade do analito detectado. Outro fator importante está na posição de dessorção da fibra dentro do injetor. Esse parâmetro foi otimizado de forma que consecutivas 
extrações e dessorções se realizaram com o intuito de obter-se a maior concentração dos analitos dentro da câmara do injetor. O módulo split não é adequado para esse tipo de análise, por reduzir sensivelmente a quantidade do analito no injetor (GORECKI, PAWLISZYN, 1995).

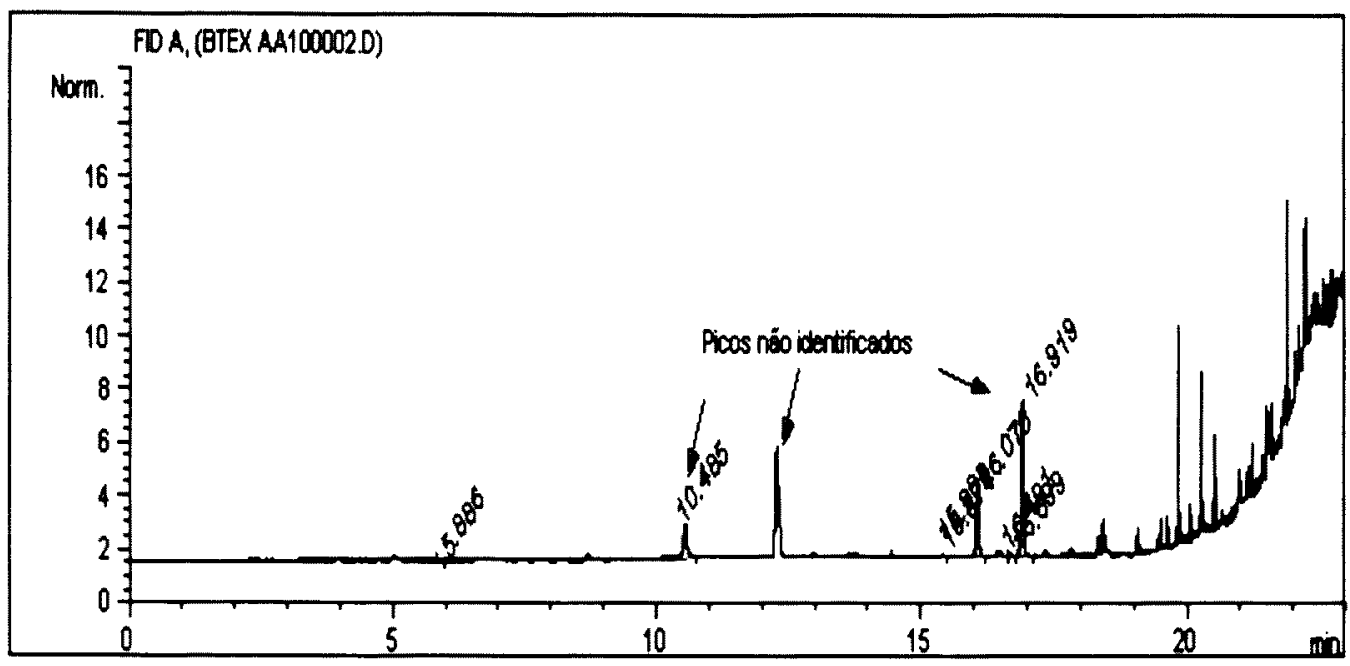

Figura 20 - Cromatograma do branco da coluna, aplicando-se as condições do método analítico, com a presença dos picos não-identificados.

A coluna capilar escolhida para a análise cromatográfica teve como fase líquida um polímero à base de polietilenoglicol, que é muito sensivel à presença de oxigênio e pode degradar-se facilmente com o aumento da temperatura. Ao se degradar o polímero, este poderá fragmentar-se em pequenas moléculas que eluem aleatoriamente, provocando interferência nos picos de interesse.

$\mathrm{Na}$ figura 20, observa-se um exemplo de cromatograma com picos não-identificados, assinalados pelas flechas. Quando um composto não-identificado elui junto com os picos analíticos, tem-se um aumento da área/altura, prejudicando-se a quantificação dos compostos de interesse. Esse efeito foi minimizado condicionando-se a coluna cromatográfica na temperatura de $250^{\circ} \mathrm{C}$ durante 12 horas e, posteriormente, avaliando-se a 
qualidade da linha de base. No cromatograma da figura 21, observou-se a diminuição do nivel de ruído da linha de base e da presença de picos estranhos. Somente após se obter uma linha de base completamente isenta de ruido, iniciaram-se os testes com a fibra.

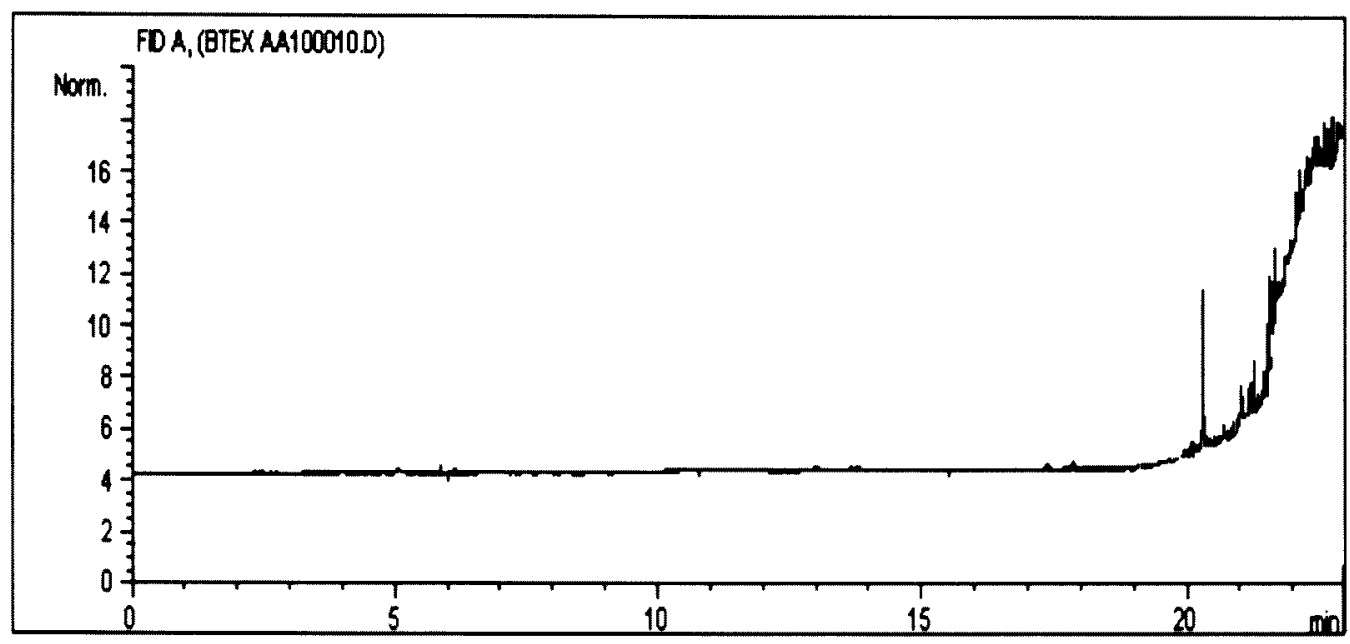

Figura 21 - Cromatograma do branco da coluna, aplicando-se as condições do método analítico, com a eliminação dos picos "fantasmas".

\subsubsection{Avaliação da sensibilidade da fibra com os contaminantes presentes no ambiente do laboratório}

A escolha certa de uma técnica de extração muitas vezes se depara com dificuldades na sua aplicação. Em alguns casos, ocorrem contaminações cruzadas com interferentes do ambiente do laboratório analítico, comprometendo-se os resultados obtidos. Colunas de extração SPE (Solid Phase Extration) são muito eficientes para extração de vários tipos de analitos presentes na água ou no solo, mas, quando não são previamente limpas, ou seja, condicionadas, podem disponibilizar componentes absorvidos do ar e causar sobreestimação dos resultados. 
Em virtude das dificuldades dos métodos de limpeza $e$ concentração das amostras, da disponibilidade de um laboratório equipado adequadamente e do elevado custo dos equipamentos analíticos, optou-se por um método de extração mais simples, com o qual foi possivel conjugar um método de extração, concentração e posterior dessorção direta dos analitos no sistema cromatográfico, utilizando-se, assim, um único método. O sistema SPME (Solid Phase Micro-Extration), escolhido para extração e concentração, demonstra ser, segundo o fabricante SUPELCO (1998), simples e eficiente para uma gama muito ampla de compostos quimicos presentes no meio ambiente. Esse sistema pode ser utilizado tanto para extrações por imersão direta em água como para análise em sistema de headspace estático.

Antes de iniciar as determinações, as fibras SPME novas foram instaladas adequadamente no suporte manual $e$, posteriormente, condicionadas conforme prescrito pelo fabricante. O condicionamento básico foi realizado submetendo-se as fibras a dessorção térmica a $250^{\circ} \mathrm{C}$ durante uma hora (SUPELCO, 1999). Após o condicionamento, simulou-se uma dessorção de cinco minutos para eliminar possiveis interferentes e residuos de solventes presentes na cola que fixa a fibra. Esse processo foi complementado realizando-se a imersão da fibra em água destilada e purificada em Milli Q e, em seguida, realizou-se uma nova dessorção. Houve dificuldade para eliminar os interferentes da fibra, o que foi solucionado quando submetemos as fibras a uma nova dessorção no injetor no módulo spliter, numa vazão constante de $200 \mathrm{~mL} /$ minuto, a $250^{\circ} \mathrm{C}$, durante duas horas. Com esse novo procedimento, atingiu-se o nosso objetivo de eliminar completamente todos os interferentes. 


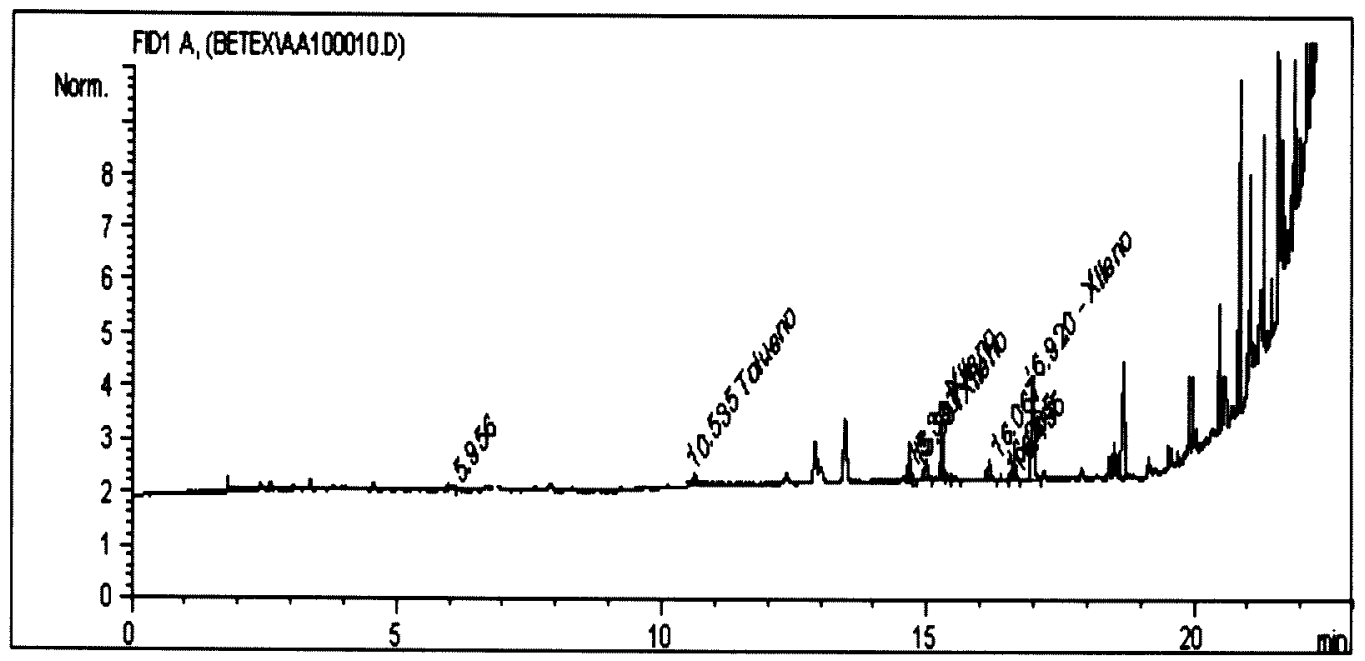

Figura 22 - Cromatograma dos compostos adsorvidos na fibra após dessorção sem proteção de um septo de silicone.

Outro problema observado durante 0 processo de condicionamento da fibra foi o efeito memória da fibra, causado pela interferência dos analitos adsorvidos do ambiente do laboratório e dos padrões com concentrações maiores. Padrões analíticos de concentração abaixo de $1 \mu \mathrm{g} / \mathrm{L}$ sofriam diretamente a interferência do efeito memória da fibra e dos materiais utilizados. Em virtude desse problema, o nível de detecção do método ficou prejudicado e o nivel de quantificação deveria ser maior que $2 \mu \mathrm{g} / \mathrm{L}$ para não sofrer influência da área produzida pelos analitos adsorvidos do ambiente.

Durante o processo de ajustes, observou-se que, ao se deixar a fibra exposta no ambiente do laboratório, ela adsorvia uma certa quantidade de vapores de solventes (BTEX), aumentando-se o efeito memória por muito tempo, sendo necessárias várias dessorções adicionais para eliminarem-se os interferentes. Inicialmente realizamos um teste protegendo a fibra com um septo de silicone condicionado a $230^{\circ} \mathrm{C}$, o qual se revelou ser relativamente eficiente, mas ainda podendo interferência no método. Nesse momento, já era possivel diminuir o nivel de detecção para $0,5 \mu \mathrm{g} / \mathrm{L}$ e ter um nível de quantificação em torno de $1 \mu \mathrm{g} / \mathrm{L}$ para tolueno, etil 
benzeno e $0, m$ e p-xileno. Para o benzeno, em virtude da baixa sensibilidade do detector, o nivel de detecção permanecia acima de $1 \mu \mathrm{g} / \mathrm{L} \mathrm{e}$ o de quantificação em $2 \mu \mathrm{g} / \mathrm{L}$.

Durante o processo de desenvolvimento analítico, observou-se que, mesmo protegendo a fibra com o septo de silicone, os niveis de ruído e de contaminantes permaneciam os mesmos. Dessa forma, concluímos que a borracha do septo de silicone também adsorve os solventes residuais do ambiente, confirmando-se um estoque natural de BTEX. No momento em que se introduziu a agulha da seringa no septo, os solventes adsorvidos passaram a ser compartilhados com o recobrimento da fibra, entrando em equilibrio com ela. Uma vez adsorvidos os solventes, a fibra passou a ter um efeito memória praticamente constante (Figura 22).

O laboratório de preparação de amostra e de cromatografia a gás utilizado para a análise do presente estudo está instalado numa área onde outros laboratórios normalmente utilizam tolueno, etil benzeno e xileno, o que contribui para o aumento do nível de contaminantes no ambiente, comprometendo-se a realização das análises residuais nessa área.

Para minimizar esse problema, adaptou-se um frasco de vidro do amostrador automático com tampa de rosca e septo de silicone faceado com um filme de teflon. $O$ frasco, antes de ser fechado, foi submetido a uma purga de 2 minutos com nitrogênio ou hélio grau cromatográfico. Dentro do frasco, permanecia uma atmosfera de nitrogênio ou hélio puro, para evitar que a fibra fosse contaminada com BTEX presente no ambiente. Após o condicionamento da fibra, a agulha contendo a fibra foi introduzida nesse frasco durante o tempo em que ela não estivesse sendo utilizada para a extração ou dessorção dos analitos, como também para ser armazenada entre as análises. Uma segunda dessorção da fibra, após permanecer em repouso no nitrogênio, demonstrou uma diminuição dos contaminantes (Figura 23). 
$\mathrm{Na}$ tabela 3, demonstram-se as diferenças de áreas dos picos contaminantes, em que o $m$-xileno, por ser o principal composto encontrado nas misturas de isômeros de xileno, também é o composto que apresenta maior dificuldade de se eliminar o efeito memória da fibra.

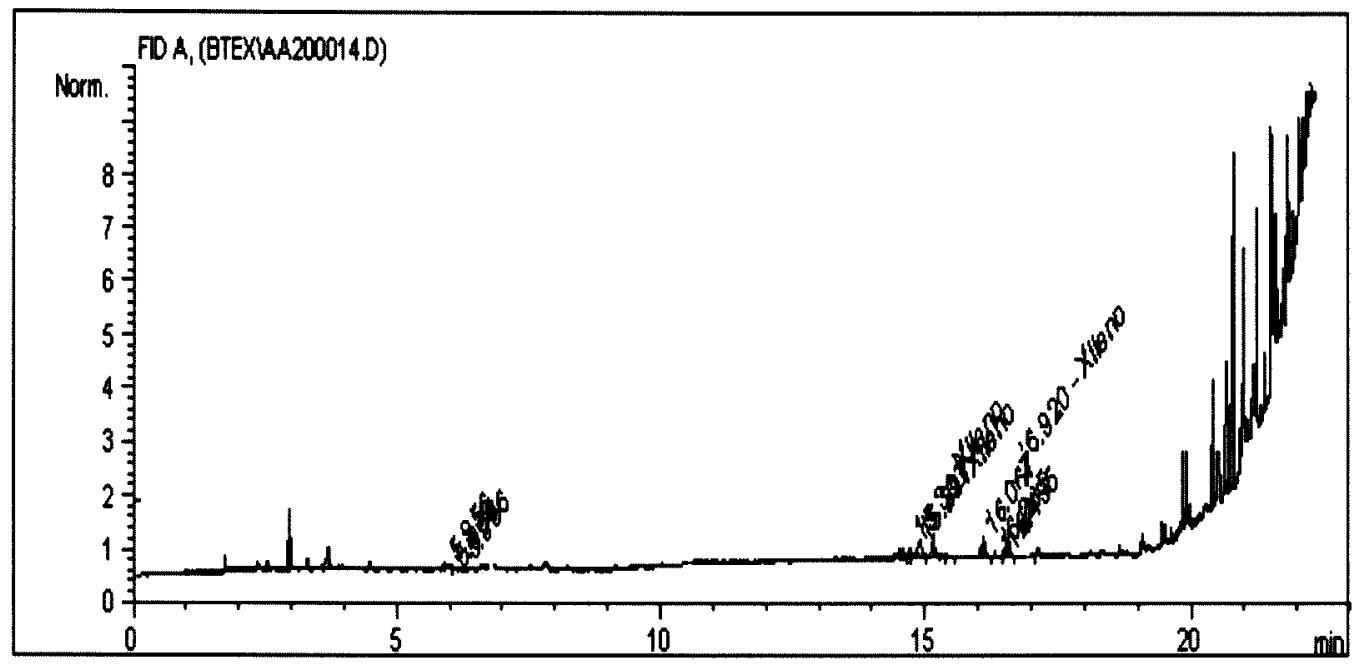

Figura 23 - Cromatograma do branco da fibra, protegida com nitrogênio.

Tabela 3 - Comparação da área dos picos dos compostos de interesse, após consecutivas dessorções e da diminuição da ÁrealAltura dos picos contaminantes.

\begin{tabular}{lccc}
\hline Compostos & $\begin{array}{c}\text { Fibra protegida } \\
\text { com o septo de } \\
\text { silicone }\end{array}$ & $\begin{array}{c}\text { Fibra protegida } \\
\text { com Nitrogênio } \\
1^{\circ} \text { dessorção }\end{array}$ & $\begin{array}{c}\text { Fibra protegida } \\
\text { com Nitrogênio } \\
2^{\circ} \text { dessorção }\end{array}$ \\
\hline Benzeno & - & - & - \\
Tolueno & $8,94 \times 10^{-2}$ & - & - \\
Etil benzeno & $4,27 \times 10^{-1}$ & $1,17 \times 10^{-1}$ & $9,36 \times 10^{-2}$ \\
p-xileno & $2,02 \times 10^{-1}$ & $7,03 \times 10^{-2}$ & - \\
m-xileno & $4,41 \times 10^{-1}$ & $1,62 \times 10^{-1}$ & $1,12 \times 10^{-1}$ \\
o-Xileno & $1,88 \times 10^{-1}$ & $1,13 \times 10^{-1}$ & - \\
& & & \\
\hline
\end{tabular}


No cromatograma da figura 24 , observou-se que a fibra teve uma real diminuição do efeito memória, $\mathrm{e}$ a área desses picos praticamente não irá interferir no cálculo dos picos analíticos. Entretanto, todos os artifícios criados conseguirão reduzir o efeito memória da fibra. Nesse momento, testou-se a possibilidade de a fibra permanecer no injetor após a dessorção dos analitos, de forma que se evitasse a contaminação dela. Nesse estágio do processo de otimização, manteve-se a fibra dentro do injetor sob um fluxo suficiente de gás de arraste da purga do septo, para evitar a contaminação da fibra e modificações nas condições gerais do método. Para avaliar o condicionamento da fibra, realizou-se uma dessorção de cinco minutos, conforme padronizado no método, e observou-se a total eliminação dos picos dos analitos adsorvidos do ambiente do laboratório. Prática esta também observada por MENENDEZ (2000), que menciona a necessidade de se manter a fibra dentro do injetor do cromatógrafo, para evitar adsorção ambiental. Esse procedimento nem sempre pode ser utilizado, visto que a maioria dos cromatógrafos são equipados somente de um injetor.

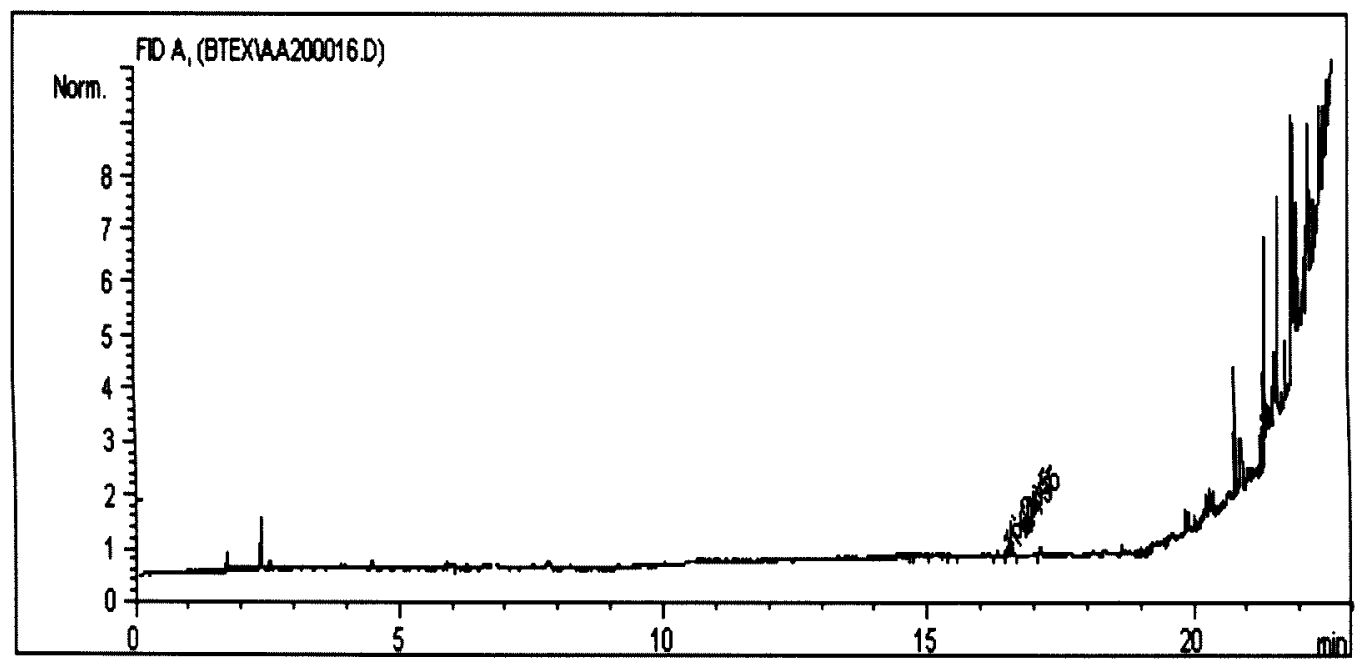

Figura 24 - Cromatograma do branco da fibra após uma segunda dessorção, mantido sob ambiente inerte. 
Figura 25 - Cromatograma do branco da fibra após permanência dentro do injetor, sob um fluxo constante de $20 \mathrm{~mL} /$ minuto de hidrogênio.

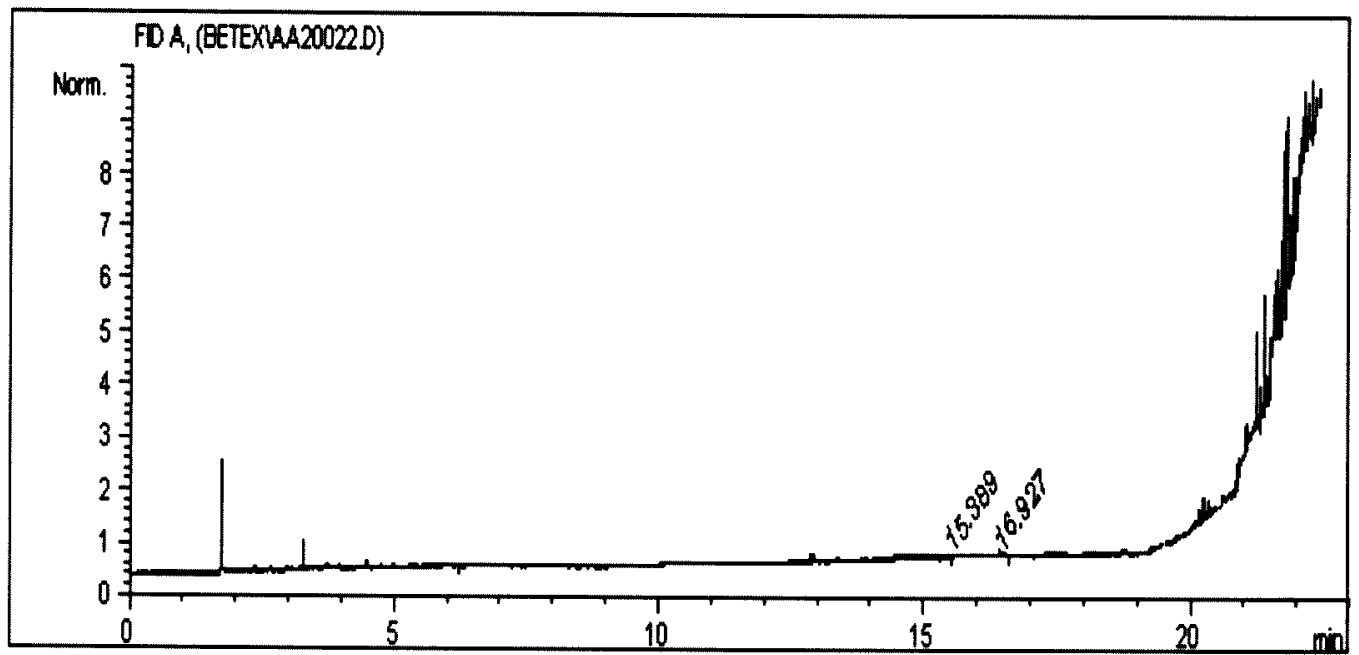

$\mathrm{Na}$ figura 25, observa-se uma sensivel diminuição dos ruídos da linha de base e dos contaminantes ambientais, após se manter a fibra constantemente dentro do próprio injetor utilizado para análise. Essa prática foi possivel pela manutenção de um fluxo constante da purga de septo do injetor em $20 \mathrm{~mL} /$ minuto, após a solenóide do injetor splitless se abrir. Adotado esse procedimento, observou-se uma diminuição no nivel de ruído e praticamente se eliminou o efeito memória da fibra entre as injeções, havendo, conseqüentemente, uma melhora da repetibilidade entre as injeções.

\subsubsection{Interferência do material de vidro e da água utilizada para preparação dos padrões}

Outro problema identificado que contribuiu para interferir nos resultados da análise diz respeito à propriedade dos frascos de vidro de reterem em sua estrutura solventes BTEX em baixas concentrações. Os septos de silicone faceados com teflon também adsorvem os solventes das 
soluções analíticas, como também aqueles presentes no ambiente do laboratório. Em ambos os casos, contribui-se significativamente para o efeito memória da fibra.

Para eliminar esse efeito, todo o material foi lavado e deixado sob a ação oxidante de uma solução de sulfocrômica por um dia; posteriormente tudo foi enxaguado com água purificada em Milli $Q$ e deixado na estufa a $230^{\circ} \mathrm{C}$ por três horas. Os septos de silicone foram lavados e posteriormente deixados na estufa para dessorver os solventes adsorvidos no filme de borracha.

Após a dessorção térmica da vidraria, os frascos e septos foram resfriados até atingirem a temperatura ambiente e armazenados em dessecador sob atmosfera de nitrogênio grau cromatográfico. Esse procedimento diminuiu sensivelmente o problema do efeito memória.

Durante o processo de otimização do método analítico, observou-se também que os cromatogramas dos padrões analíticos com concentrações inferiores a $2 \mu \mathrm{g} / \mathrm{L}$ não apresentavam diferenças.

Pesquisaram-se os solventes utilizados para preparação e concluiu-se que a água destilada e posteriormente purificada no sistema Milli $Q$ era inadequada para a preparação dos padrões. Observou-se que 0 equipamento utilizado para purificação não era adequado para essa finalidade, por não ser munido de um dispositivo que emita raios ultravioleta, capazes de eliminar a presença de material orgânico dissolvido abaixo de 20 $\mathrm{mg} / \mathrm{L}$. Esse problema foi resolvido utilizando-se água captada diretamente de um poço semi-artesiano de 160 metros de profundidade. Inicialmente a água era estocada em bombona plástica por um período de no máximo cinco dias, porém testes realizados durante esse período indicaram um aumento da concentração de BTEX, provavelmente pela contaminação das bombonas expostas no ambiente. Para resolver esse problema, adotou-se uma 
sistemática de estocagem em frascos de vidros herméticos com purga de hélio durante 12 horas. As análises cromatográficas realizadas indicaram não haver contaminação de BTEX após a adoção do novo procedimento.

\subsubsection{Otimização do método via extração direta do analito em água}

Com o intuito de desenvolver uma sistemática simples e rápida, decidiu-se iniciar o trabalho utilizando a técnica de extração direta com a fibra SPME. Realizaram-se várias tentativas, mas sem o sucesso desejado, em virtude de a extração por imersão ser extremamente sensivel a variações de $\mathrm{pH}$, temperatura, concentração de sais, agitação, altura da fibra, entre outras. Alguns artigos consultados indicam a possibilidade de ser realizada a extração de BTEX entre outros compostos voláteis e semivoláteis por meio de imersão direta, mas, na prática, não demonstraram a eficiência desejada para o BTEX.

Durante o processo de desenvolvimento, constatou-se que não era possivel obter uma extração constante dos analitos. Isso foi verificado por meio da preparação de uma curva de calibração simples, que inicialmente demonstrava ter um coeficiente de linearidade $r^{2}$, variando entre 0,97 e 0,99. Nesse trabalho inicial, identificaram-se grandes variações entre os padrões, por meio da comparação entre duas injeções. Para o padrão de $1 \mu \mathrm{g} / \mathrm{L}$, a variação observada ficou entre 6 e $30 \%$ e, para o padrão de 20 $\mu \mathrm{g} / \mathrm{L}$, entre 0,2 e $2 \%$. Na tabela 4 e nas figuras 26 e 27 , podem-se observar as diferenças e variações entre as injeções do padrão de $1 \mu \mathrm{g} / \mathrm{L}$ e do padrão de $20 \mu \mathrm{g} / \mathrm{L}$. 
Tabela 4 - Comparação entre a repetibilidade de duas injeções do padrão de $1 \mu \mathrm{g} / \mathrm{L}$ e duas injeções do padrão de $20 \mu \mathrm{g} / \mathrm{L}$, através de injeção direta.

\begin{tabular}{|c|c|c|c|c|}
\hline Substância & $\begin{array}{c}\text { Altura do } \\
\text { pico Padrão } \\
\text { de } 1 \mu \mathrm{g} / \mathrm{L}\end{array}$ & $\begin{array}{c}\text { \% variação } \\
\text { entre duas } \\
\text { injeções }\end{array}$ & $\begin{array}{c}\text { Altura do } \\
\text { pico Padrão } \\
\text { de } 20 \mu \mathrm{g} / \mathrm{L}\end{array}$ & $\begin{array}{c}\text { \% variação } \\
\text { entre duas } \\
\text { injeções }\end{array}$ \\
\hline Benzeno & $\begin{array}{l}2,46 \times 10^{-1} \\
2,63 \times 10^{-1}\end{array}$ & 6,4 & $\begin{array}{l}16,56 \\
16,68\end{array}$ & 0,7 \\
\hline Tolueno & $\begin{array}{l}1,04 \\
1,36\end{array}$ & 23,3 & $\begin{array}{l}46,03 \\
45,52\end{array}$ & 1,1 \\
\hline Etil benzeno & $\begin{array}{l}1,79 \\
1,27\end{array}$ & 20,8 & $\begin{array}{l}49,87 \\
49,56\end{array}$ & 0,6 \\
\hline p-Xileno & $\begin{array}{l}1,73 \\
2,04\end{array}$ & 15,0 & $\begin{array}{l}72,64 \\
74,01\end{array}$ & 1,9 \\
\hline$m$-xileno & $\begin{array}{l}2,15 \\
2,99\end{array}$ & 28,2 & $\begin{array}{l}74,00 \\
74,17\end{array}$ & 0,2 \\
\hline o-Xileno & $\begin{array}{l}1,73 \\
2,01\end{array}$ & 13,9 & $\begin{array}{l}81,74 \\
82,60\end{array}$ & 1,1 \\
\hline
\end{tabular}

As variações observadas para o padrão de $1 \mu \mathrm{g} / \mathrm{L}$ podem estar sendo afetadas diretamente pelo efeito memória da fibra, conforme previsto anteriormente, que até esse momento não tinha sido ainda identificado como fator de erro para a determinação.

No padrão de maior concentração, a variação é menor, ficando dentro da faixa de valores aceitáveis para este tipo de análise. Outros pontos de menores concentrações foram avaliados e apresentaram o mesmo comportamento do padrão de $1 \mu \mathrm{g} / \mathrm{L}$, mas com menor variação. 


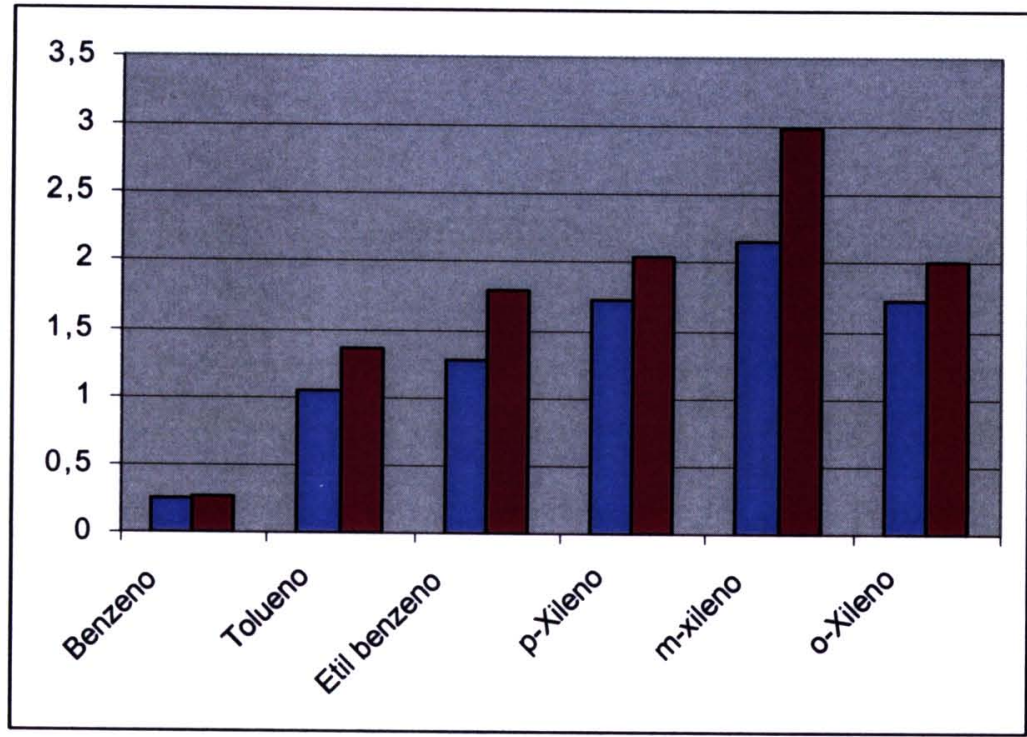

Figura 26 - Comparação entre duas injeções do padrão de $1 \mu \mathrm{g} / \mathrm{L}$. A barra azul representa a primeira extração dos analitos e a barra vermelha, a segunda extração.

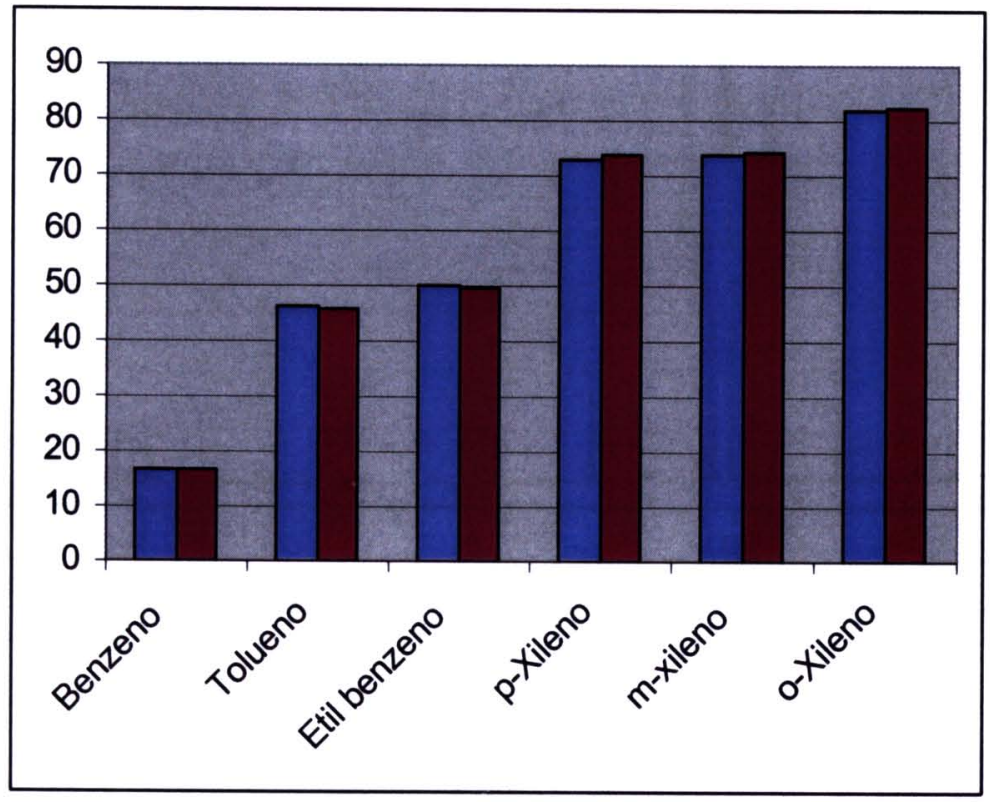

Figura 27 - Comparação entre duas injeções do padrão de $20 \mu \mathrm{g} / \mathrm{L}$. A barra azul representa a primeira extração dos analitos e a barra vermelha, a segunda extração. 


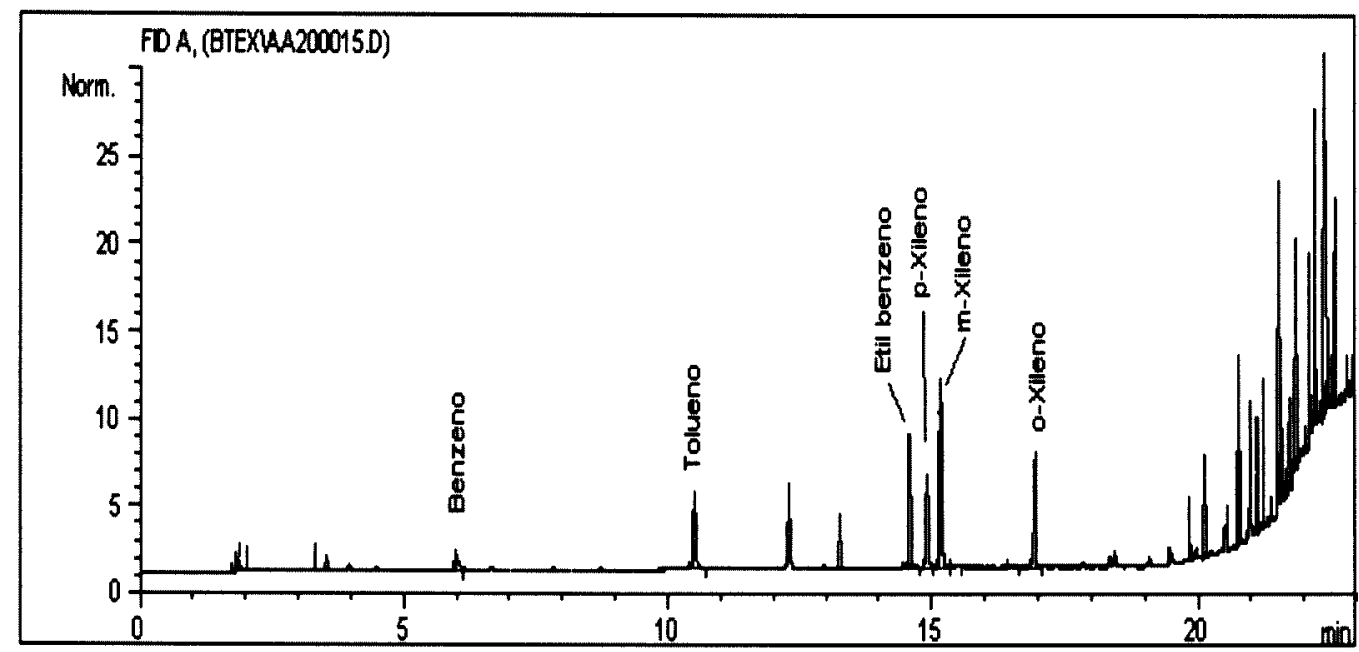

Figura 28 - Cromatograma do padrão de concentração $1 \mu \mathrm{g} / \mathrm{L}$; primeira injeção.

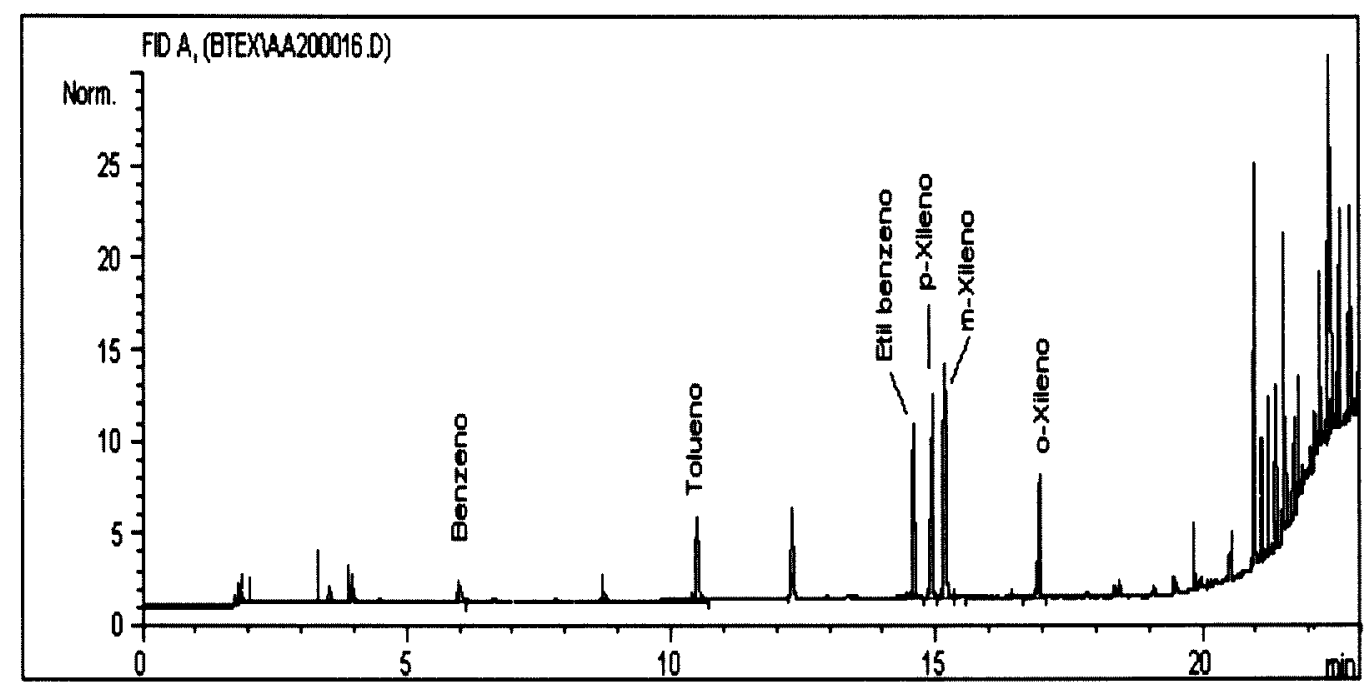

Figura 29 - Cromatograma do padrão de concentração $1 \mu \mathrm{g} / \mathrm{L}$; segunda injeção.

Nos cromatogramas acima, observou-se a interferência do efeito memória produzida no pico do $m$-xileno do cromatograma (Figura 28 ); esse problema é devido ter-se uma substância sendo eluída junto com o 
composto ( $m$-xileno) ou até mesmo o próprio composto adsorvido do ambiente ou do septo de silicone.

O mesmo composto no cromatograma da figura 29 apresenta menos interferência $e$, conseqüentemente, menor influência na sua área/altura. No segundo caso, se os cromatogramas mantivessem o mesmo perfil, teria sido possivel obter menores variações nos resultados. Outro ponto observado sobre as variações de área/altura poderia estar agregado à presença de outras substâncias orgânicas na água, as quais competem entre si e com o grupo BTEX durante o equilibrio entre os analitos e o filme da fibra. Em virtude de o processo de extração por imersão não apresentar repetibilidade satisfatória, como também diminuir o tempo de vida da fibra, optou-se por trabalhar com um método de extração por headspace.

\subsubsection{Otimização do método via extração dos analitos por headspace estático}

O primeiro passo no sentido da otimização do método de extração via headspace estático foi a avaliação geral das condições analiticas e de possiveis interferentes. Durante o processo de otimização do método por injeção direta, observaram-se vários problemas, referentes a contaminações cruzadas pelo uso inadequado da fibra e pelo efeito memória, causados pelos materiais, problemas esses conseqüentemente válidos também para o processo de extração por headspace.

A escolha do método de headspace estático para extração do grupo BTEX se baseou no fato de ser uma técnica já utilizada por outros autores, com bons resultados (ZHANG e PAWLISZYN, 1993; GORECKI e PAWLISZYN, 1995; PAWLISZYN, 1997; MATISOVÁ et al., 1999 e SHIREY, 2000). Observou-se que o processo de extração via headspace apresenta duas vantagens: a primeira é que o equilibrio é atingido na maioria das 
vezes à temperatura ambiente e a segunda é que há uma melhora na durabilidade da fibra.

O sistema de headspace foi montado utilizando-se um béquer de $100 \mathrm{~mL}$ em substituição a uma cuba de vidro. Nesse béquer, instalou-se um suporte de plástico para fixar os frascos de vidro de $7 \mathrm{~mL}$, sobre uma chapa aquecedora com controle de temperatura e munida de um sistema de agitação magnética. A temperatura foi controlada utilizando-se um termômetro instalado dentro do banho, ao lado do frasco com a solução a ser analisada (Figura 30). Esse dispositivo foi otimizado com os equipamentos disponíveis no laboratório, a fim de se obter baixo custo da análise.

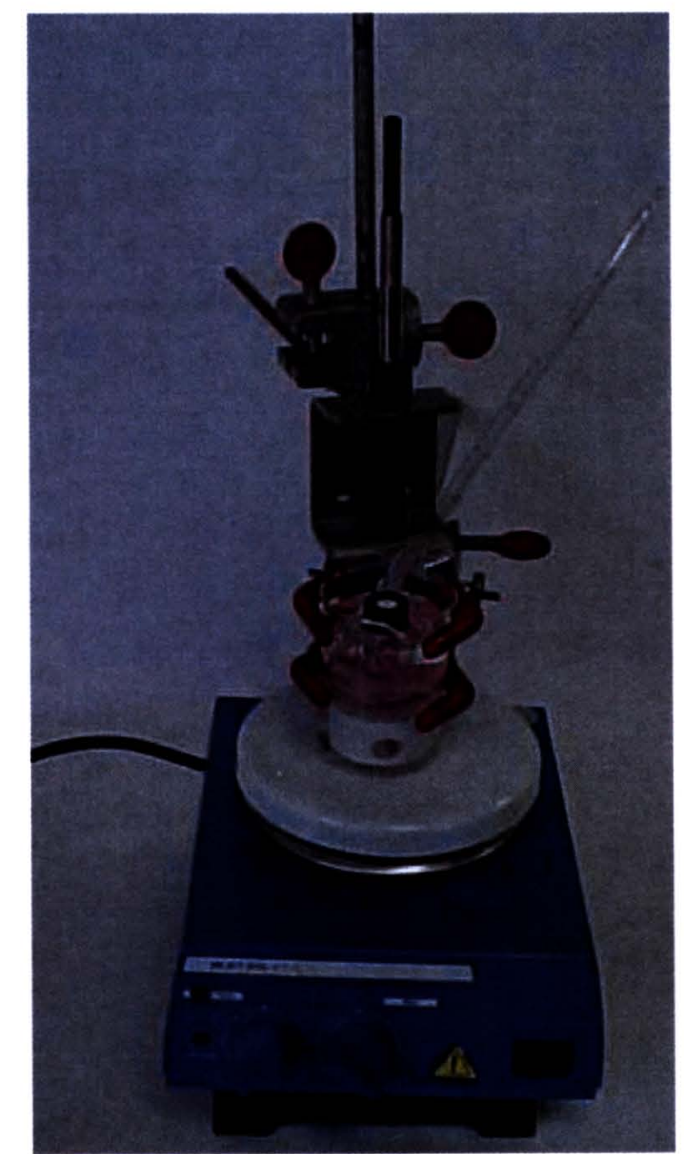

Figura 30 - Equipamento para extração dos analitos por headspace. 


\subsubsection{Avaliação da influência da força iônica}

Com o intuito de melhorarmos a extração dos analitos, realizou-se uma seqüência de extrações com um padrão de $1 \mu \mathrm{g} / \mathrm{L}$, adicionando-se $20 \%$ de cloreto de sódio sobre o volume de amostra analisado. Observou-se um aumento significativo nas áreas do tolueno e benzeno e uma melhora para os demais compostos (Tabela 5 e Figura 31). A adição de cloreto de sódio durante a extração por headspace torna-se necessária para melhorar o equilíbrio entre a fase líquida e vapor.

Tabela 5 - Comparação da influência de cloreto de sódio na extração dos analitos.

\begin{tabular}{ccc}
\hline Compostos & $\begin{array}{c}\text { Área - Sem a presença } \\
\text { de cloreto de sódio }\end{array}$ & $\begin{array}{c}\text { Área - Com a } \\
\text { presença de cloreto } \\
\text { de sódio }\end{array}$ \\
\hline Benzeno & $1,07 \times 10^{-1}$ & $2,09 \times 10^{-1}$ \\
Tolueno & $4,46 \times 10^{-1}$ & $7,62 \times 10^{-1}$ \\
Etil benzeno & 2,00 & 2,83 \\
p-Xileno & 1,45 & 2,07 \\
m-Xileno & 2,54 & 3,69 \\
o-Xileno & 1,15 & 1,87 \\
& & \\
\hline
\end{tabular}

A ação do cloreto de sódio baseia-se na mudança de polaridade do meio com a diminuição da solubilidade do grupo BTEX na água. Dessa forma, o cloreto de sódio provoca o aumento da força iônica do meio, deslocando $o$ analito da fase líquida para a fase vapor $e$, 
conseqüentemente, aumentando nessa fase (vapor) a concentração do analito.

PAWLISZYN (1997) associou uma melhora da extração quando a amostra é saturada com cloreto de sódio. Essa prática foi testada e tivemos dificuldade em agitar a amostra, pois se formam muito precipitado no fundo do frasco, dificultando-se a ação da barra magnética e sua permanência em movimento uniforme.

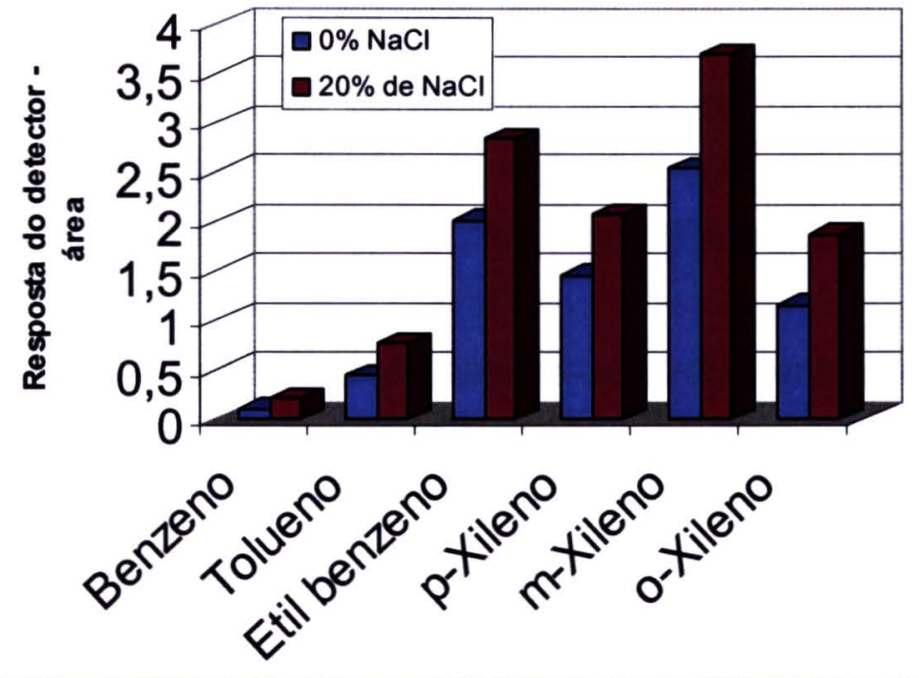

Figura 31 - Comparação entre uma extração sem e uma extração com cloreto de sódio. A barra azul representa a extração sem cloreto de sódio e a barra vermelha, a extração realizada com $20 \%$ de cloreto de sódio.

Como medida preventiva, todo o cloreto de sódio utilizado para análise foi submetido a uma dessorção prévia, deixando-se o sal a $230^{\circ} \mathrm{C}$ em uma estufa durante oito horas. Após a eliminação de possíveis 
solventes adsorvidos, o cloreto de sódio foi estocado em frasco de vidro hermético sob atmosfera inerte de nitrogênio dentro de um dessecador.

\subsubsection{Determinação do tempo ideal de extração}

Do ponto de vista analítico, deve-se considerar a necessidade de serem ajustados todos os parâmetros que podem causar erros durante a determinação analítica. O sistema de amostragem por headspace para analitos voláteis tem como principal vantagem atingir rapidamente 0 equilíbrio entre $\mathrm{o}$ analito e a fibra extratora, entretanto fatores como tempo, temperatura e agitação definem as melhores condições de análise. 0 parâmetro agitação não foi testado neste estudo, em razão de o equipamento ter sido utilizado no máximo da escala de agitação. Nesse processo, é fundamental utilizar uma agitação vigorosa para facilitar a transferência do analito da fase líquida para vapor (PAWLISZYN, 1997).

O processo de extração associa-se diretamente com o tempo e a temperatura utilizada para extrair os analitos do grupo BTEX. Nesse sentido, optou-se por otimizar o método identificando-se inicialmente o tempo necessário para obter o máximo de extração dos analitos. Na figura 32 e na tabela 6, observou-se que o tempo ideal de extração foi de dez minutos. É possivel observar no gráfico o aumento constante da extraçăo dos analitos até atingir dez minutos, quando se atinge o equilibrio de extração máximo. A partir desse ponto, o equilibrio entre a fibra e a fase vapor diminui de forma gradativa com a diminuição da área dos analitos. Esse teste foi realizado utilizando-se um padrão de $100 \mu \mathrm{g} / \mathrm{L}$.

A temperatura melhora o deslocamento dos analitos voláteis para a fase vapor, facilitando a obtenção do equilíbrio entre as fases (Figura 33). Por causa das variações de temperatura ambiental do laboratório durante o dia, foi necessário termoestatizar o frasco amostrador em um 
banho, dessa forma se evitando mudanças bruscas de temperatura e alterações na constante de equilíbrio dos vapores e da fibra. Essas mudanças afetam diretamente o equilíbrio, variando a concentração do analito na fibra, como também a precisão do método analitico (PAWLISZYN, 1997).

Tabela 6 - Avaliação do tempo de extração através da comparação da altura do pico de um padrão de $100 \mu \mathrm{g} / \mathrm{L}$ com o tempo de exposição da fibra

\begin{tabular}{ccccccc}
\hline $\begin{array}{c}\text { Tempo de } \\
\text { exposição } \\
\text { (minutos) }\end{array}$ & Benzeno & Tolueno & $\begin{array}{c}\text { Etil } \\
\text { benzeno }\end{array}$ & p-Xileno & m-Xileno & o-Xileno \\
\hline 1 & 4,24 & 10,51 & 21,26 & 21,78 & 23,44 & 23,60 \\
5 & 4,90 & 11,56 & 25,60 & 23,54 & 27,99 & 27,061 \\
10 & 5,68 & 13,11 & 44,46 & 32,85 & 48,02 & 33,34 \\
15 & 5,26 & 12,06 & 37,87 & 27,72 & 40,83 & 30,19 \\
20 & 5,50 & 11,48 & 39,52 & 25,81 & 42,30 & 27,06 \\
25 & 6,00 & 12,27 & 31,45 & 23,33 & 34,57 & 26,56 \\
\hline
\end{tabular}

Outro fator importante que afetou a extração dos analitos foi a altura e a posição da fibra instalada logo abaixo do septo, ou seja, no gargalo do frasco de vidro sobre a fase líquida. A agulha contendo a fibra foi instalada no centro do frasco de vidro. Uma vez otimizados esses parâmetros, permaneceram fixos até o final do processo analítico. PAWLISZYN (1997) também observou que a melhor posição da fibra era logo abaixo do septo de silicone, no inicio do gargalo do frasco. 


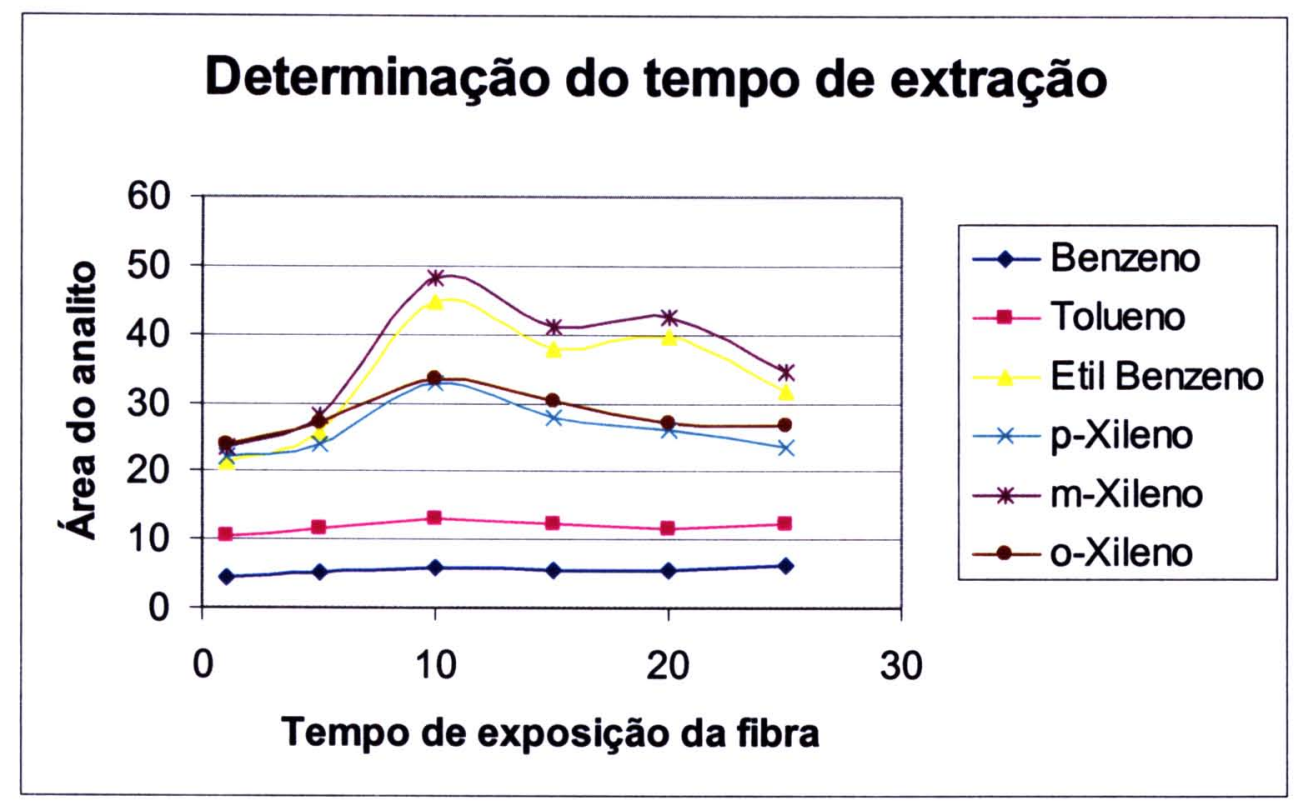

Figura 32 - Comparação da área total obtida $x$ tempo de extração para o benzeno, tolueno, etil benzeno, $p$-xileno, $m$-xileno e $o$-xileno para um padrão de $100 \mu \mathrm{g} / \mathrm{L}$.

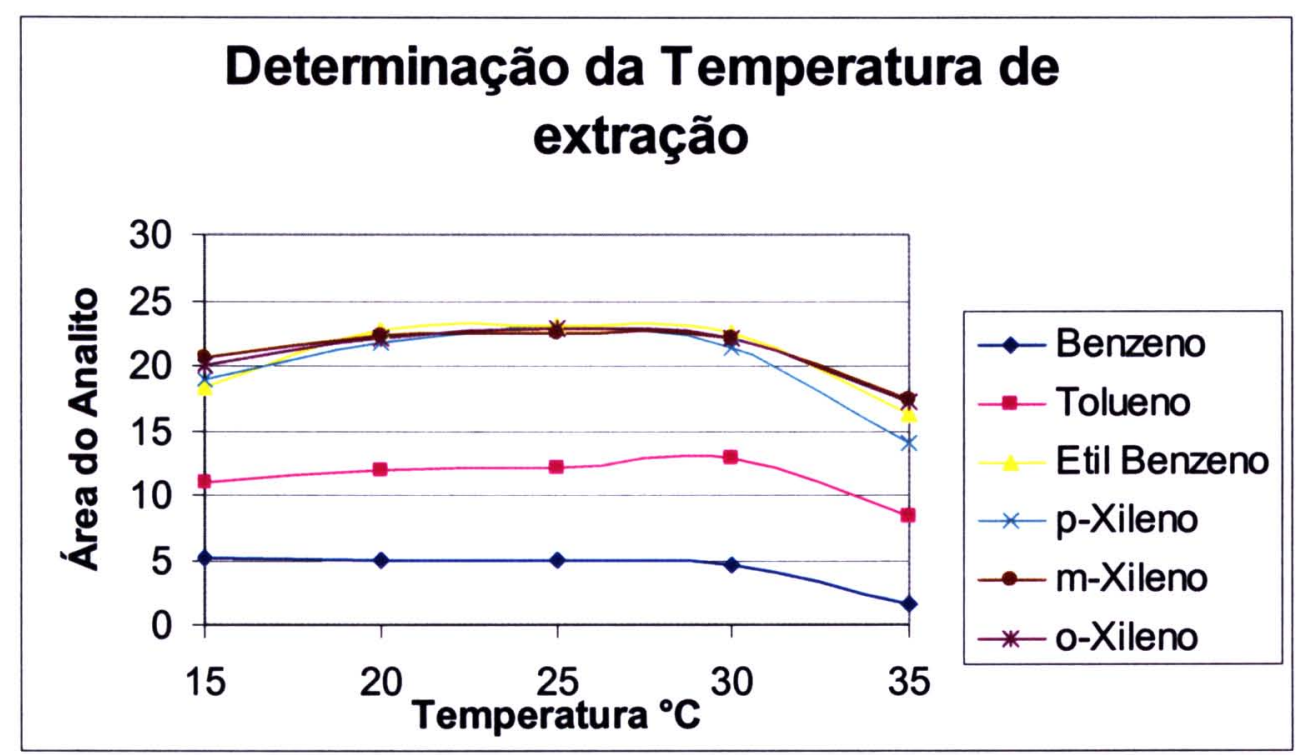

Figura 33 - Comparação da área total obtida $x$ a temperatura de extração para o benzeno, tolueno, etil benzeno, $p$-xileno, $m$-xileno e o-xileno, utilizando-se um padrão de $100 \mu \mathrm{g} / \mathrm{L}$. 


\subsubsection{Utilização de volumes reduzidos de solventes}

Comparando-se este método do presente estudo com as técnicas tradicionais de extração e clean-up, observa-se que o volume de solvente nele utilizado é bastante reduzido, pois na preparação dos padrões se utilizam somente $10 \mathrm{~mL}$ de metanol. Com a utilização da fibra SPME, nenhum solvente é utilizado durante a preparação e análise das amostras. Conclui-se, dessa forma, que o método proposto atende aos critérios do Green Chemistry, com redução significativa de residuos perigosos, como também diminuição da exposição ocupacional dos trabalhadores. 


\subsection{Validação do método}

A validação do método aqui otimizado teve como objetivo garantir a confiabilidade e qualidade dos resultados obtidos no estudo, assegurando-se que esse método é apropriado para a aplicação pretendida. Durante o processo de sua validação, estudaram-se os parâmetros de seletividade, linearidade, limites de deteç̧ão (LOD) e de quantificação (LOQ), exatidão, precisão, reprodutibilidade, repetibilidade e incerteza de medição.

O estudo de seletividade foi realizado durante a otimização do método analítico, de forma a obter-se o máximo da separação dos compostos estudados, ou seja, do benzeno, tolueno, etil benzeno, p-xileno, $m$-xileno e o-xileno. Durante a otimização, identificaram-se alguns problemas referentes ao efeito memória, à contaminação da água e da fibra, os quais foram eliminados recorrendo-se aos procedimentos mencionados anteriormente.

O estudo de linearidade do método foi realizado com o auxilio de uma curva de calibração para cada um dos compostos em estudo. A determinação da faixa linear de trabalho foi realizada por meio da injeção de cinco padrões com concentrações de 1, 5, 10, 50 e $100 \mu \mathrm{g} / \mathrm{L}$, os quais foram calculados por regressão linear em uma curva-padrão, na qual " $y$ " equivale à área total e " $x$ " à concentração em $\mu \mathrm{g} / \mathrm{L}$. $O$ menor ponto da curva foi calculado como sendo a metade do valor de quantificação do método e o ponto maior foi maior que dez vezes o LOQ.

Observou-se que em todas as curvas de calibrações $0 r^{2}$ (coeficiente de linearidade) foi maior que 0,999 , a saber: 0,9996 para o benzeno, 0,9994 para o tolueno, 0,9993 para o etil benzeno, 0,9992 para o p-xileno, 0,9996 para o $m$-xileno e 0,9994 para o o-xileno, estabelecendo-se um alto grau de linearidade para o sistema analítico proposto. Os valores de 
linearidade obtidos neste estudo são próximos aos observados na literatura utilizando-se a mesma técnica SPME (DJOZORAN e ASSADI, 1997; POTTER e PAWLISZYN, 1992 e MATISOVÁ et al., 1999). Na tabela 8, observa-se a semelhança entre os resultados de linearidade deste estudo com os resultados de MATISOVÁ (1999) e AJOZAN e ASSADI (1997). Os resultados analíticos foram calculados por meio das curvas de calibrações, preparadas diariamente. 
a) Curva de calibração do benzeno

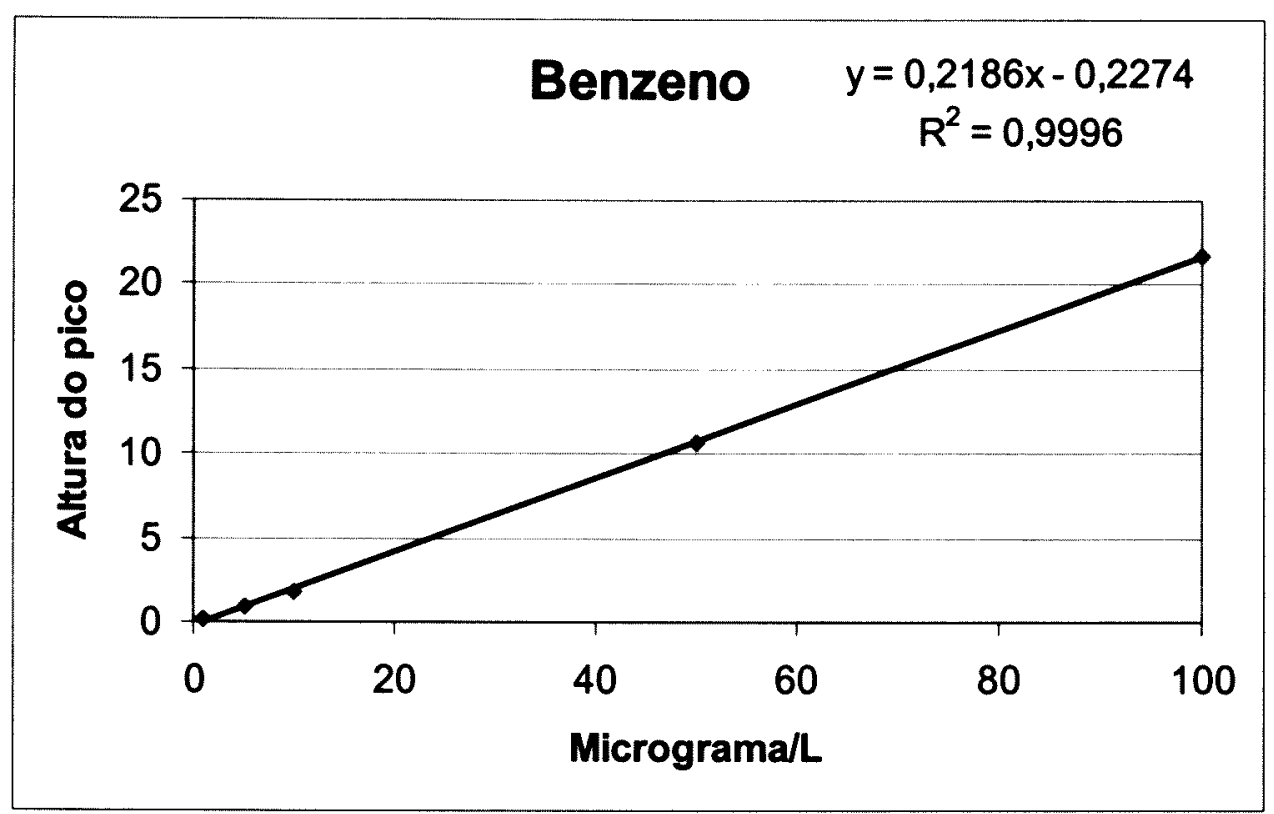

b) Curva de calibração do tolueno

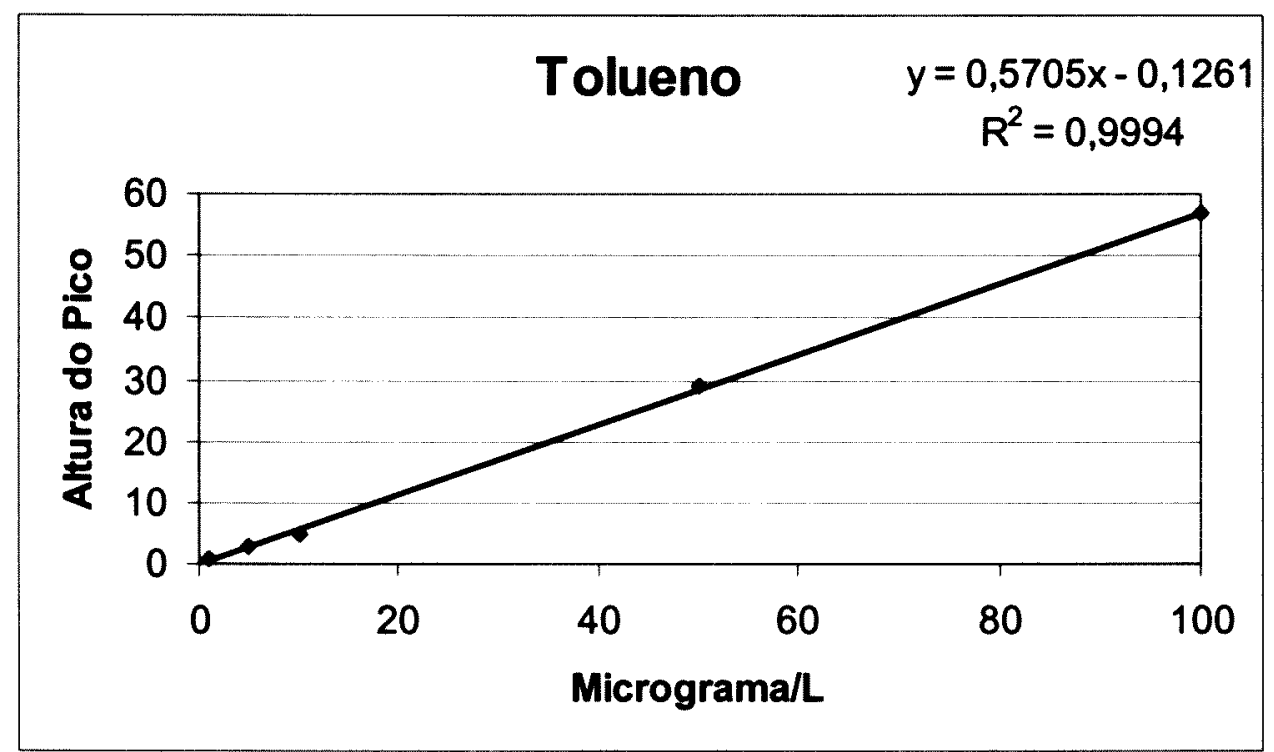


c) Curva de calibração do etil benzeno

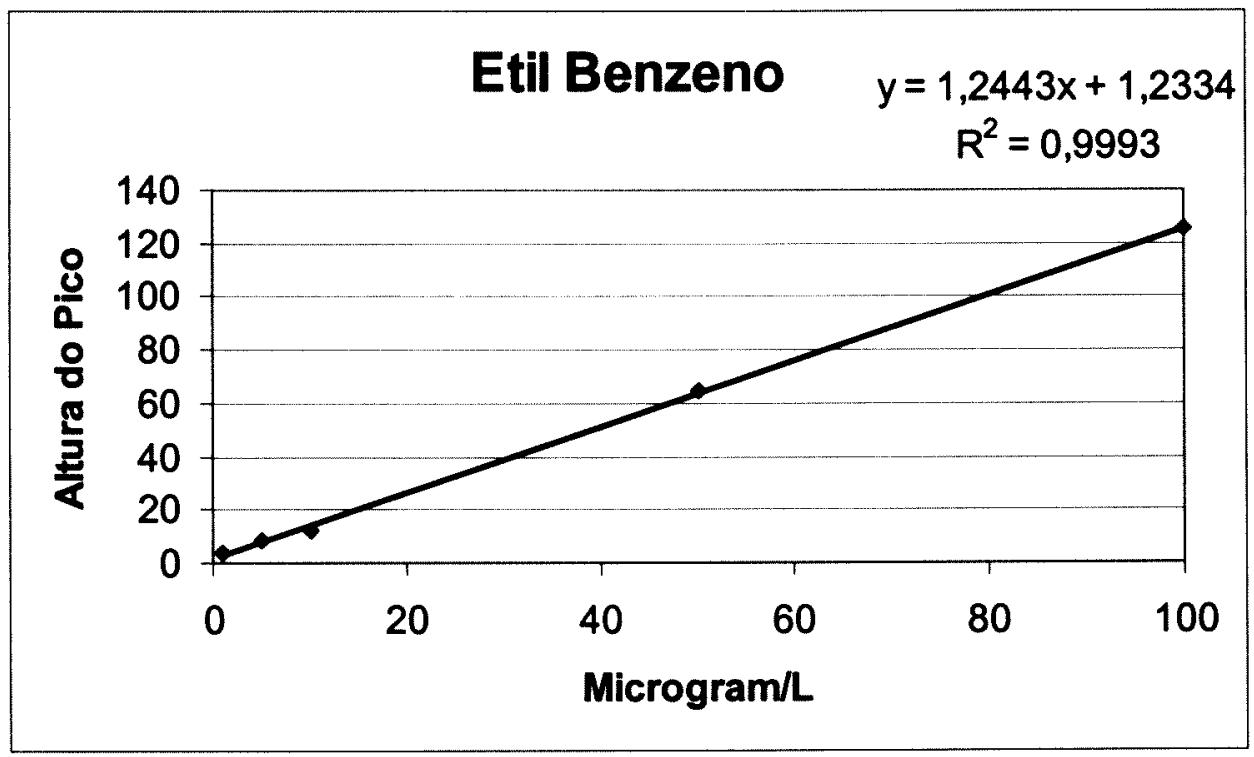

d) Curva de calibração do p-xileno

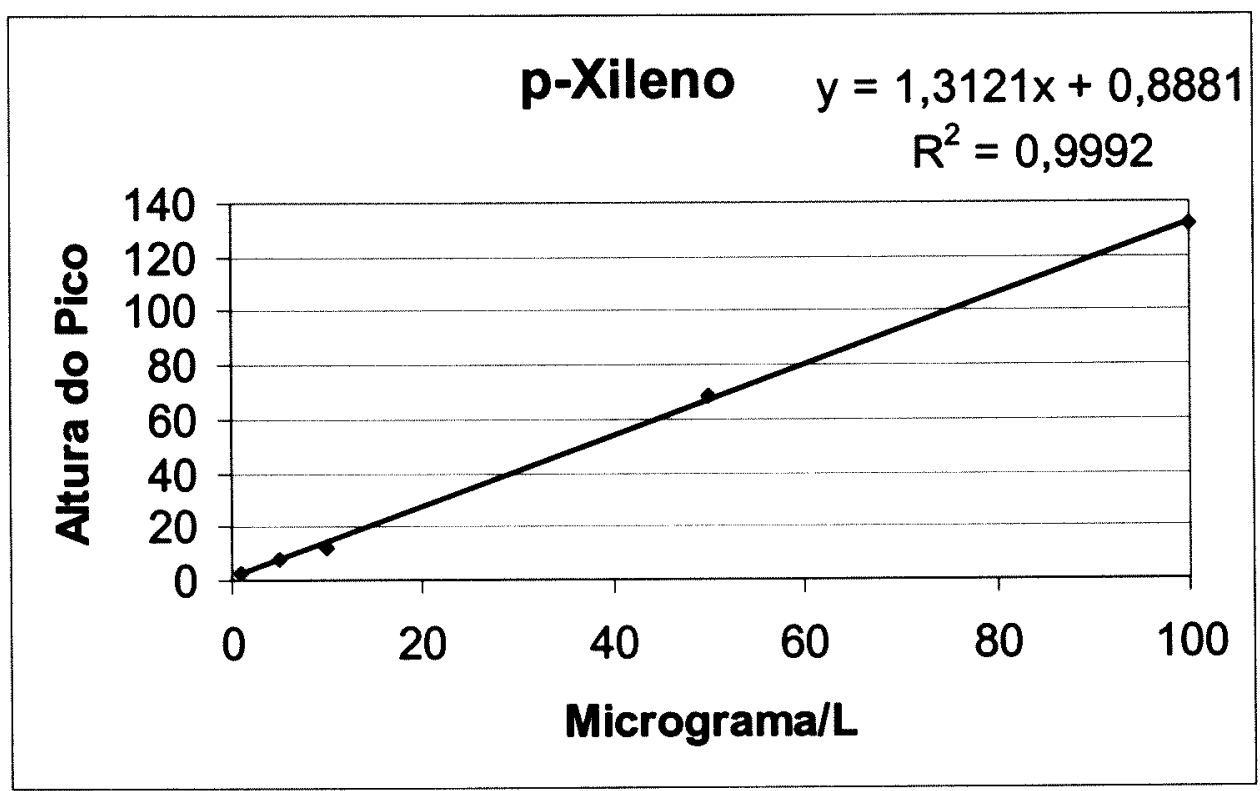


e) Curva de calibração do m-xileno

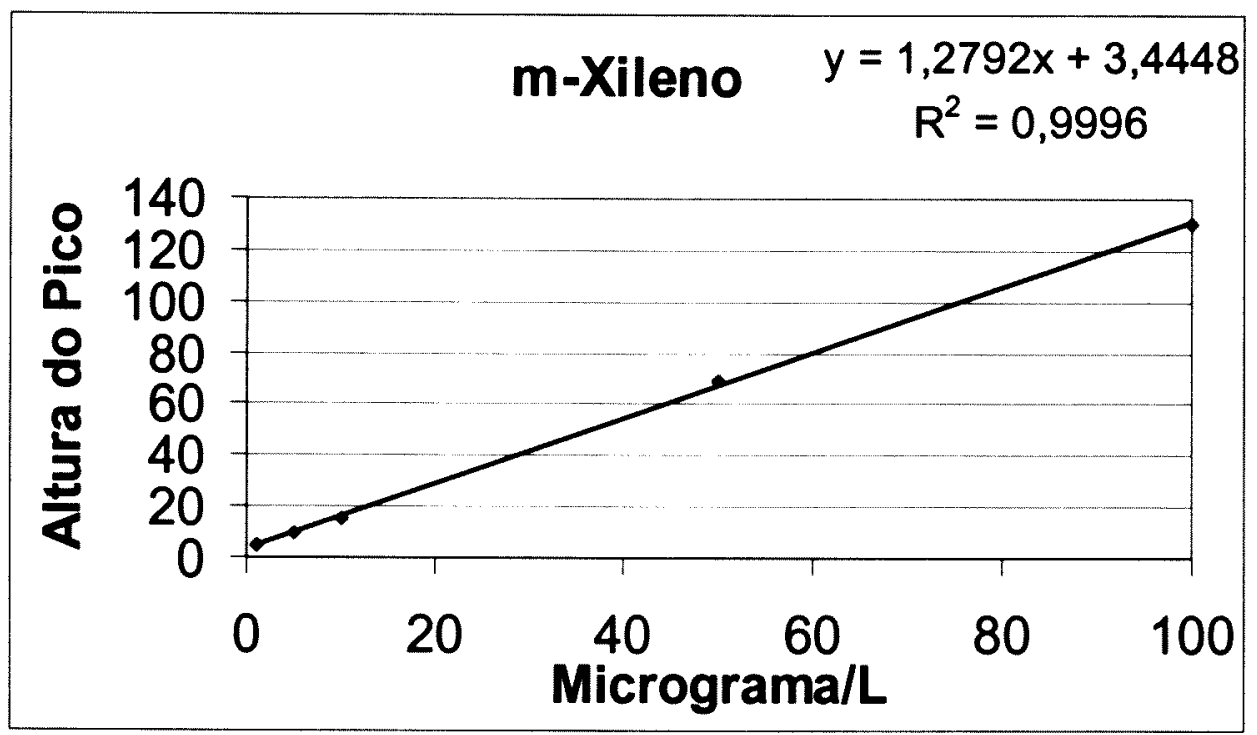

f) Curva de calibração do o-xileno

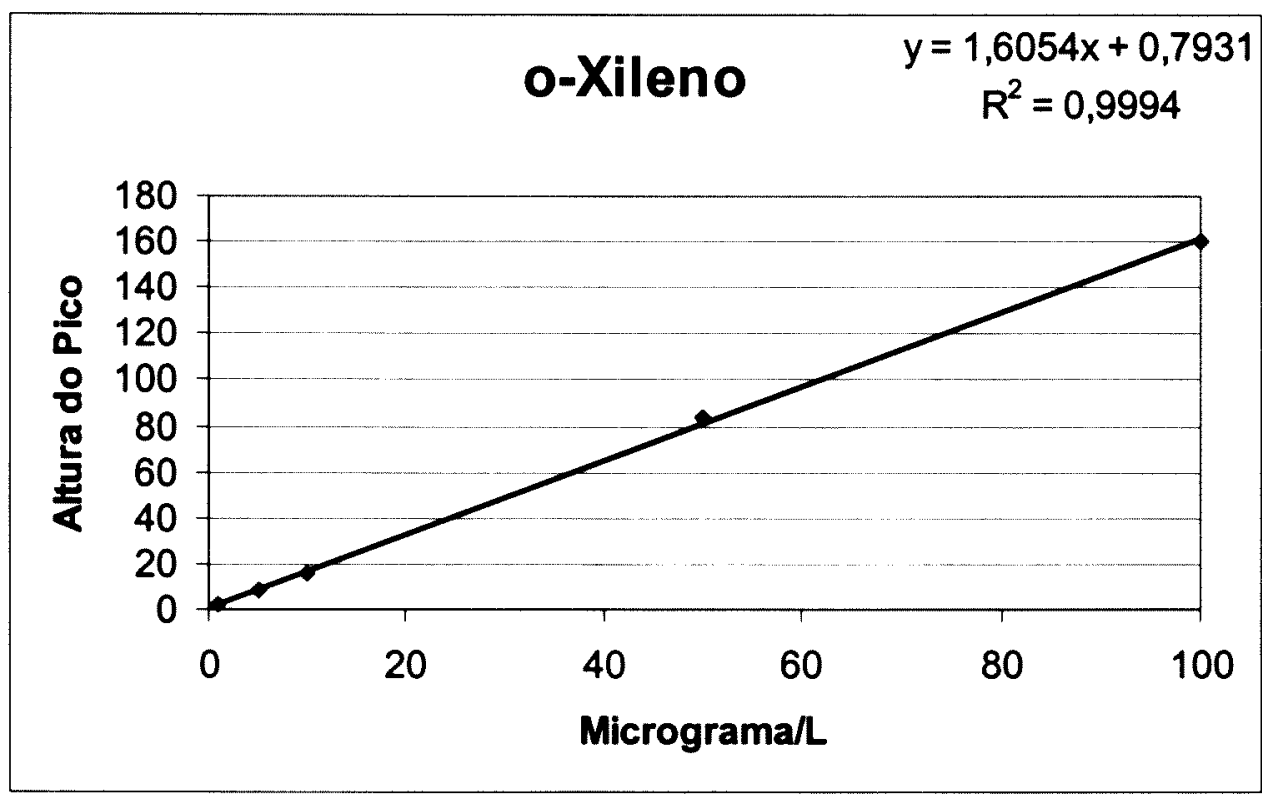

Figura 34 - Curvas de calibração do benzeno (a), tolueno (b), etil benzeno (c), p-xileno (d), m-xileno (e) e o-xileno (f). 
Comparando-se os resultados obtidos neste presente estudo, observou-se que o método otimizado tem linearidade adequada à proposta analítica. Durante o processo de avaliação da linearidade, injetaram-se alguns padrões em duplicata da curva e avaliou-se sua repetibilidade. Para o padrão de $5 \mu \mathrm{g} / \mathrm{L}$, a porcentagem de variação entre duas injeções foi menor que $3,0 \%$ e, para o padrão de $100 \mu \mathrm{g} / \mathrm{L}$, foi menor que $5,0 \%$. O limite aceitável é de $20 \%$ entre as injeções; em outras palavras, o método apresenta alta repetibilidade.

Tabela 7 - Comparação dos coeficientes de linearidade $r^{2}$ do presente estudo, com dois diferentes trabalho realizados.

\section{Componentes Presente estudo}

Matisová et al. Djozan e Assadi

$\begin{array}{llll}\text { Benzeno } & 0,9996 & 0,9992 & 0,9992 \\ \text { Tolueno } & 0,9994 & 0,9993 & 0,9997 \\ \text { Etil Benzeno } & 0,9994 & 0,9994 & 0,9996 \\ \text { p-Xileno } & 0,9992 & 0,9994 & 0,9994 \\ \text { m-Xileno } & 0,9996 & 0,9994 & 0,9995 \\ \text { o-Xileno } & 0,9994 & 0,9996 & 0,9997\end{array}$

O limite de detecção (LOD) foi determinado por meio de injeções de padrões com concentrações conhecidas de benzeno, tolueno, etil benzeno, $p$-xileno, $m$-xileno e o-xileno. $O$ valor para 0 LOD foi determinado baseando-se na medida de três vezes o ruído da linha de base (ACS 1993). A concentração mínima detectada neste estudo foi de $0,5 \mu \mathrm{g} / \mathrm{L}$, 
mas, como segurança, considerou-se o nivel de 1,0 $\mathrm{g} / \mathrm{L}$ para todas as substâncias. DZORAN e ASSADI (1997) encontraram, após análise do Detector de lonização de Chama (DIC), um limite de deteç̧ão para o benzeno e tolueno na ordem de $2,0 \mathrm{pg} / \mathrm{mL}$ e para o etil benzeno, $p-, m$ - e oxileno na ordem de $1,5 \mathrm{pg} / \mathrm{mL}$.

Comparando-se a sensibilidade obtida nesse método por detecção no DIC com outras técnicas, o fabricante da fibra SUPELCO (1998) observou que técnicas como purge and trap e headspace dinâmico têm a mesma sensibilidade ou menor, quando comparadas com o sistema de detecção por espectrometria de massa, que melhora os niveis de detecção e quantificação, chegando ao nivel de ng/L.

O limite de quantificação (LOQ) foi determinado em $5,0 \mu \mathrm{g} / \mathrm{L}$ para todos os compostos em estudo. Esse valor foi estabelecido por intermédio da fortificação (adição) dos analitos em água na concentração de $5,0 \mu \mathrm{g} / \mathrm{L}$. Realizaram-se sete determinações para cada analito no nível de $5,0 \mu \mathrm{g} / \mathrm{L}$.

Em estudos realizados por outros autores (POTTER e PALISZYN, 1992), observou-se que o limite de quantificação para o grupo BTEX pode ser menor quando detectado por espectrometria de massas.

O estudo de recuperação do método analítico foi realizado determinando-se o grau de confiabilidade do processo de extração e dessorção. Realizaram-se sete fortificaçð̃es em duas concentraçð̃es diferentes da curva de calibração ( $5 \mu \mathrm{g} / \mathrm{L}$ e $80 \mu \mathrm{g} / \mathrm{L}$ ), e cada uma dessas fortificaçōes foi injetada separadamente. 
Tabela 8 - Teste de recuperação dos analitos com um padrão de $5 \mu \mathrm{g} / \mathrm{L}$ de benzeno, tolueno, etil benzeno, p-xileno, $m$-xileno e o-xileno.

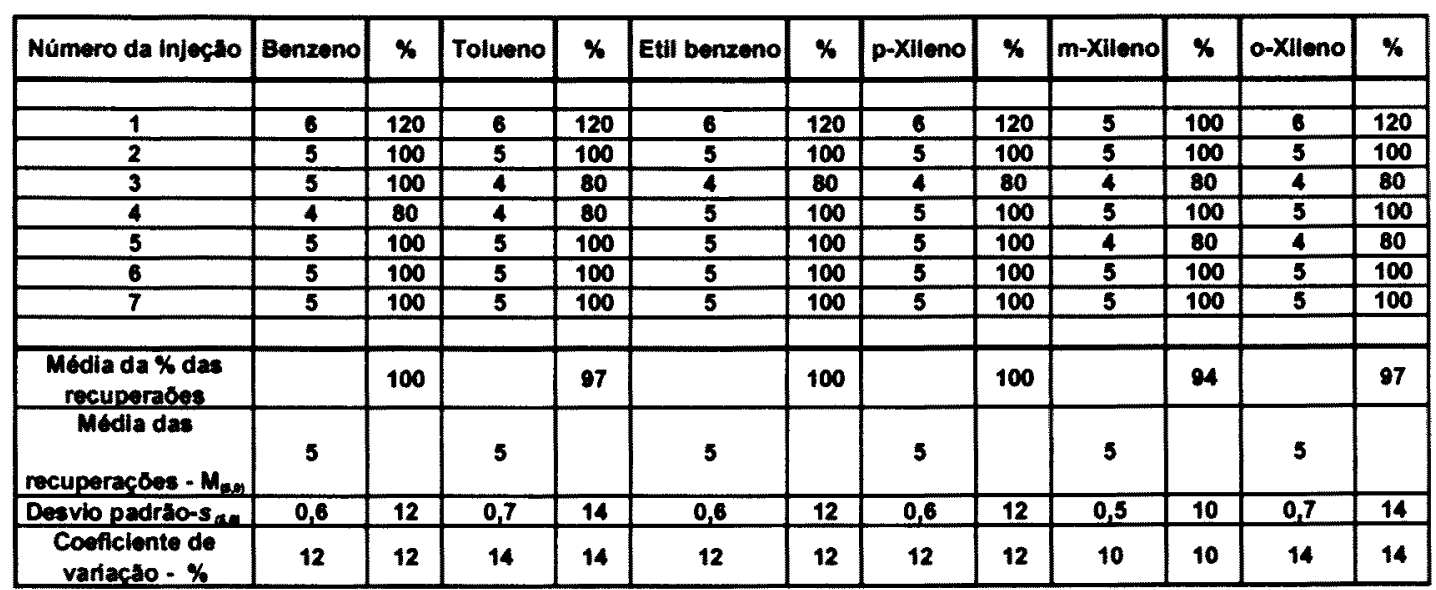

Limite de quantificaçăo (LOQ) $=5 \mu \mathrm{g} / \mathrm{L}$. - Limite de deteç̧ăo (LOD) $=1 \mu \mathrm{g} / \mathrm{L}$.

Tabela 9 - Teste de recuperação dos analitos com um padrão de $80 \mu \mathrm{g} / \mathrm{L}$ de benzeno, tolueno, etil benzeno, $p$-xileno, $m$-xileno e o-xileno.

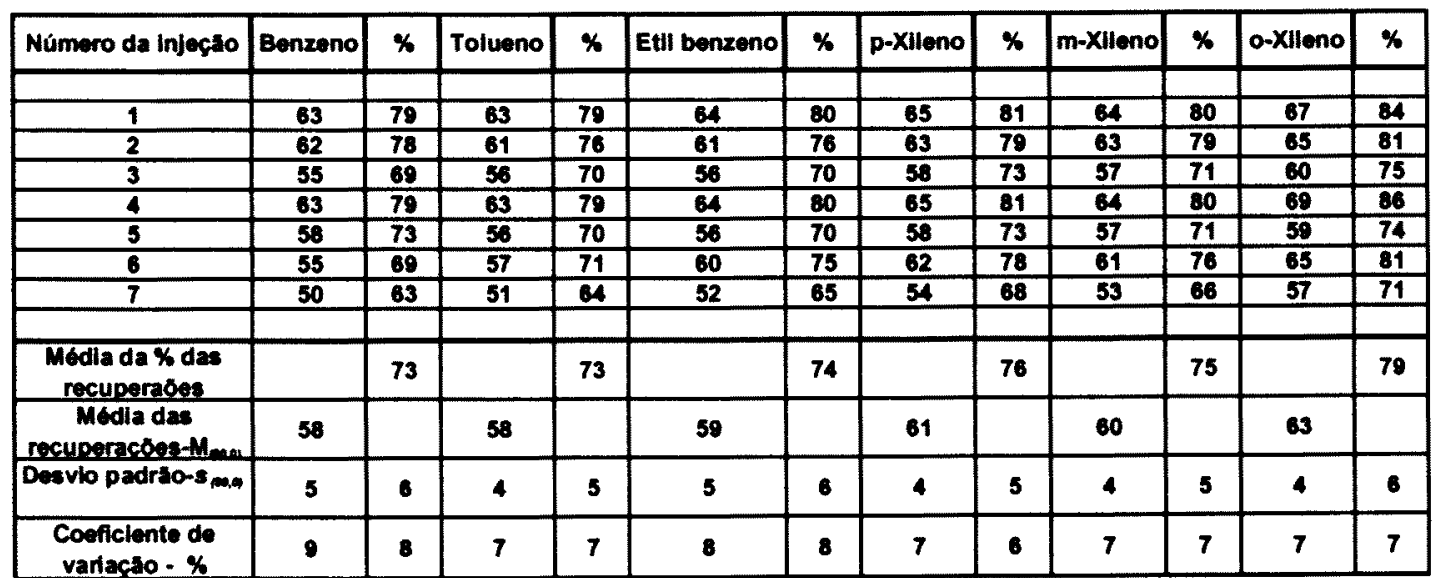

Limite de quantificaçăo $(L O Q)=5 \mu g / L$. - Limite de deteçăo $(L O D)=1 \mu g / L$. 
Nas tabelas 8 e 9, verifica-se a exatidão do método segundo o qual foram conduzidos os estudos de fortificação do BTEX nas amostras de água. Avaliaram-se dois niveis de concentração: $5 \mu \mathrm{g} / \mathrm{L}$ (limite de quantificação do método) e $80 \mu \mathrm{g} / \mathrm{L}$. Observou-se que, para todos os analitos do grupo BTEX, as recuperaçōes encontram-se dentro dos limites aceitáveis (70-120\%) (EPA, 1996). A precisão do método foi avaliada por meio do coeficiente de variaçăo obtido no estudo de recuperaçăo nos niveis de $5 \mu \mathrm{g} / \mathrm{L}$ e $80 \mu \mathrm{g} / \mathrm{L}$. O coeficiente de variação encontrado após sete determinações em cada nível também atende aos critérios de validação de método, conforme valores propostos internacionalmente $1 \leq 20 \%$ do coeficiente de variação entre as medidas) (EPA, 1996). A repetibilidade do método foi determinada avaliando-se a dispersão dos resultados de recuperação. $O$ coeficiente de variação percentual $(\mathrm{CV})$ em relação à média de recuperação para cada nivel de fortificação deve ser inferior ou igual a 20\%. Para todos os compostos do grupo BTEX no nivel de $5 \mu \mathrm{g} / \mathrm{L}$, o coeficiente de variação apresentou-se entre 10 e $14 \%$ e, para o nivel de 80 $\mu \mathrm{g} / \mathrm{L}$, o coeficiente de variação apresentou-se entre 6 e $9 \%$.

A incerteza de medição foi determinada por meio do intervalo de confiança (desvio-padrão) da média das recuperações. Para todos os compostos do grupo BTEX no nível de $5 \mu \mathrm{g} / \mathrm{L}$, o desvio-padrão apresentouse entre 0,5 e $0,7 \%$ e, para o nivel de $80 \mu \mathrm{g} / \mathrm{L}$, o desvio-padrăo apresentouse entre 4,0 e $6,0 \%$. 


\subsection{Determinação do grupo BTEX no sistema de tratamento de efluentes}

As análises das amostras de cada fase do tratamento de efluentes foram realizadas aplicando-se o método analítico otimizado. A cada batelada de amostras, realizaram-se curvas de calibrações diárias, de forma a obter-se o máximo de precisão e exatidão das determinações. A cada três amostras, injetou-se um padrão de concentração conhecido e comparado com a curva de calibração. Os valores foram aceitos quando a variação da concentração do padrão analisado era menor que $15 \%$.

Nas figuras $35,36,37, \quad 38$ e 39 reproduzem-se, respectivamente, os cromatogramas relativos às injeções dos padrões de 1 , $5,10,50$ e $100,0 \mu \mathrm{g} / \mathrm{L}$, e das figuras $40,41,42,43,44,45$ e 46 reproduzemse cada fase do tratamento.

As tabelas $11,12,13,14,15$ e 16 apresentam, respectivamente, os resultados das determinaçס̃es do grupo BTEX em todas as fases do processo de tratamento de efluentes $e$ foram inseridas diretamente no texto da discussão dos resultados da avaliação do sistema de tratamento. 


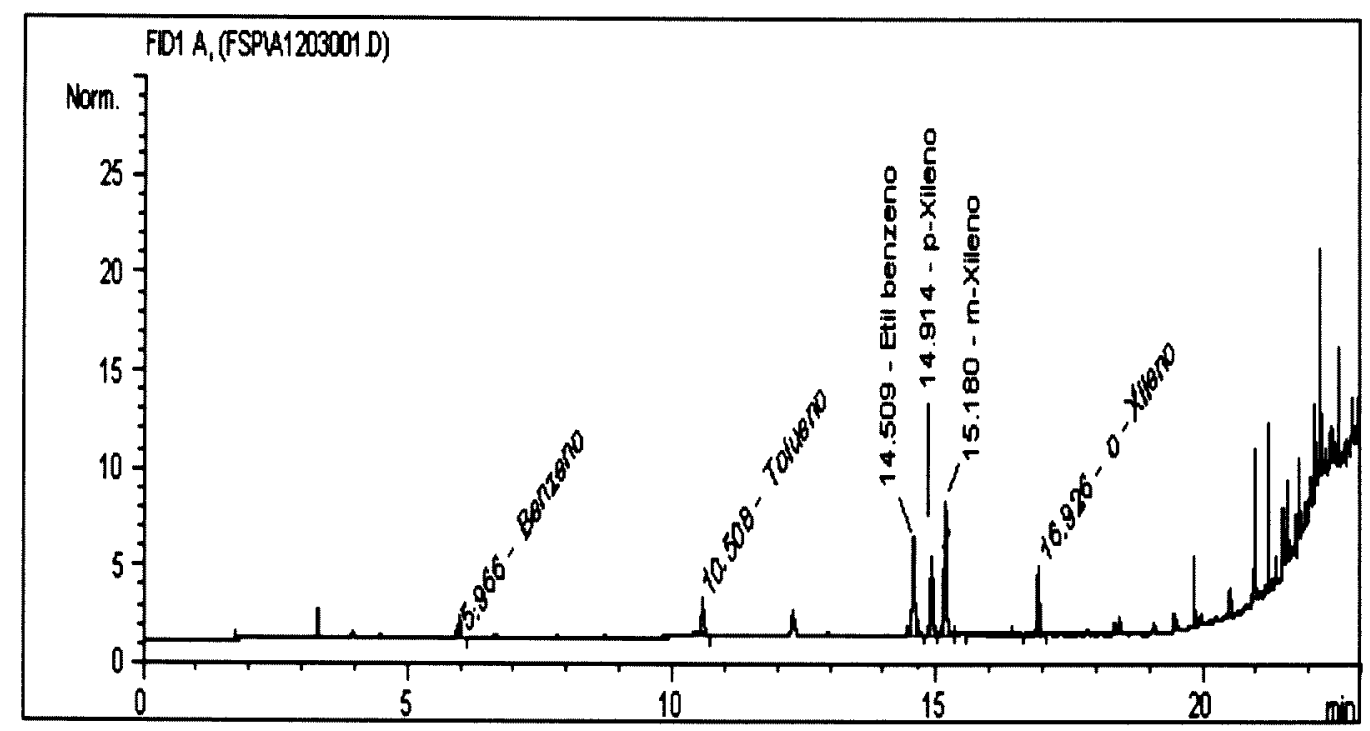

Figura 35 - Cromatograma do padrão de BTEX na concentração de $1 \mu \mathrm{g} / \mathrm{L}$ de cada componente.

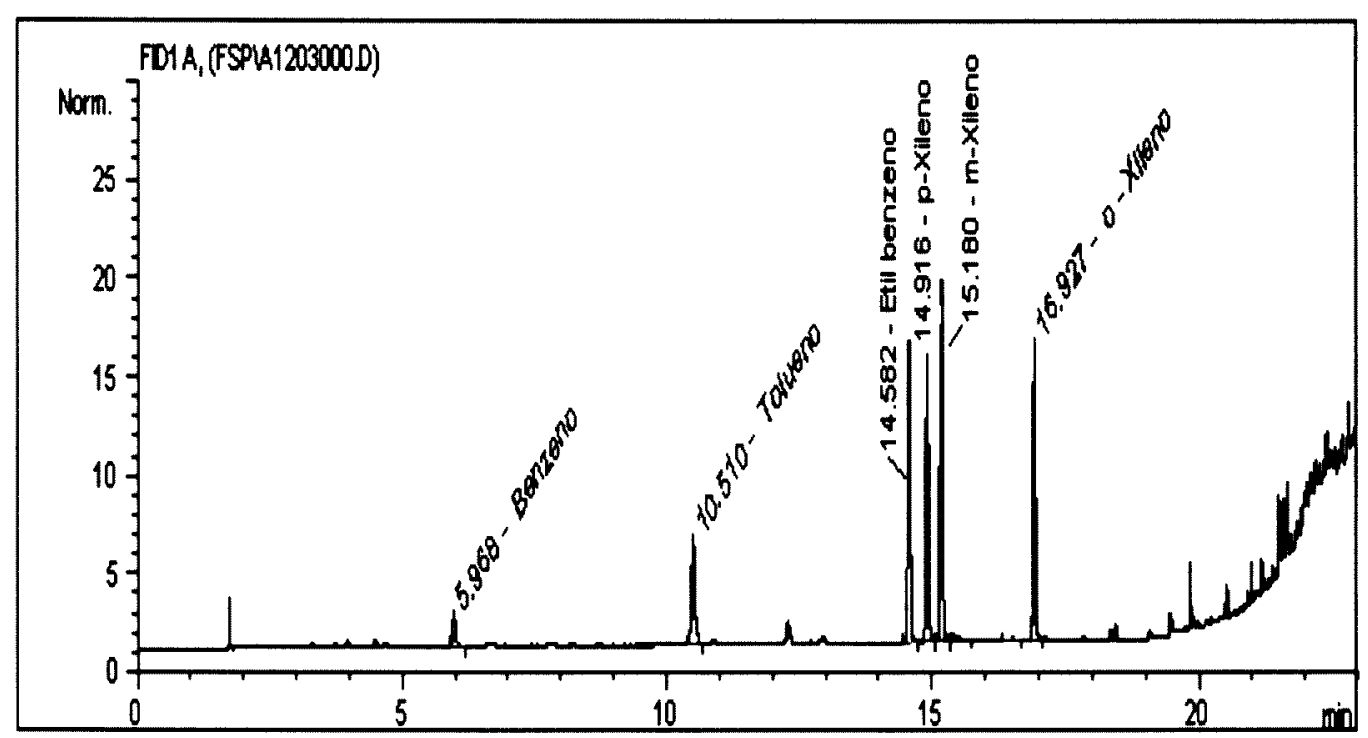

Figura 36 - Cromatograma do padrão de BTEX na concentração de $5 \mu \mathrm{g} / \mathrm{L}$ de cada componente. 


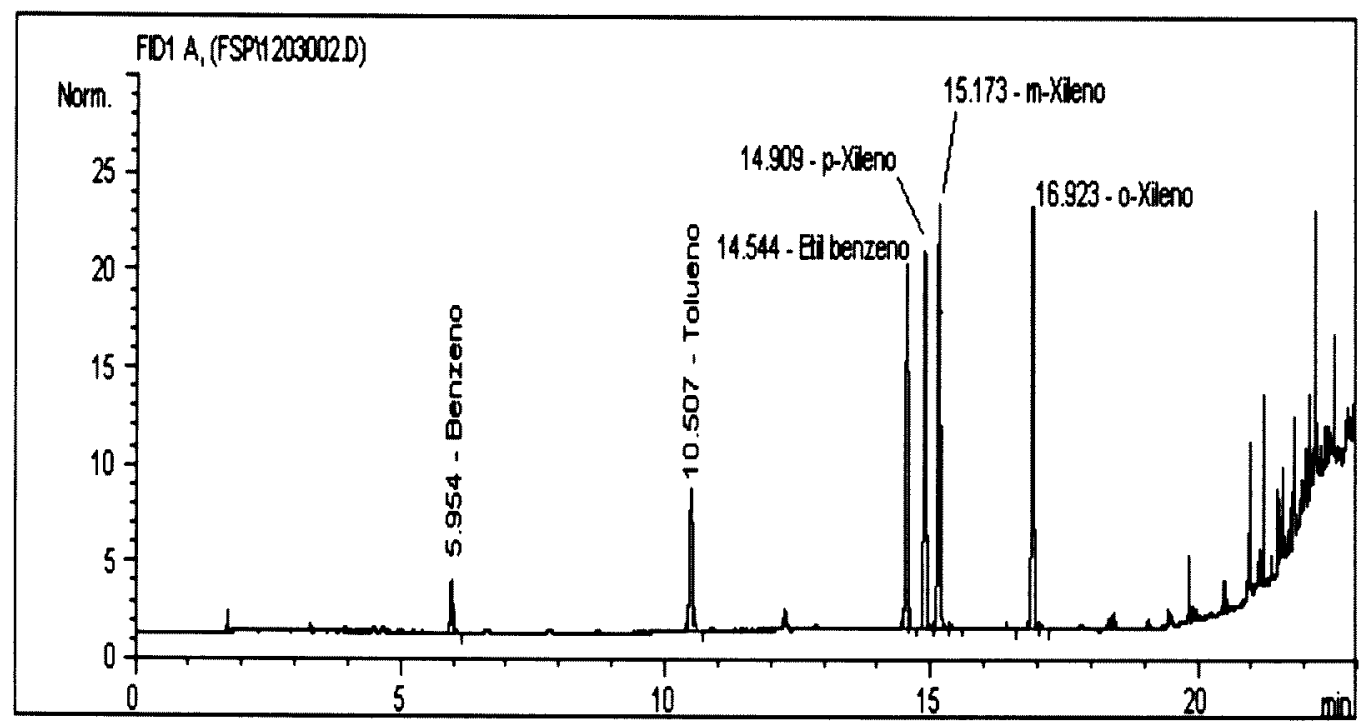

Figura 37 - Cromatograma do padrão de BTEX na concentração de $10 \mu \mathrm{g} / \mathrm{L}$ de cada componente.

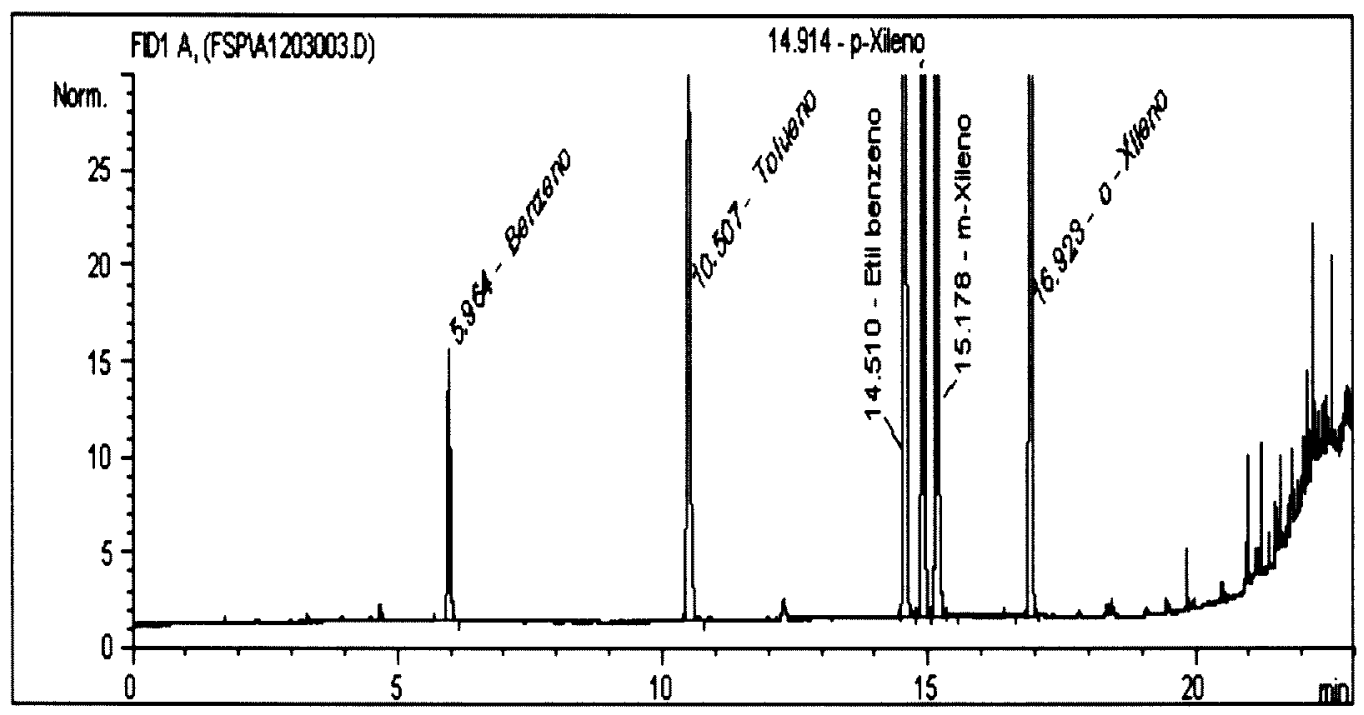

Figura 38 - Cromatograma do padrão de BTEX na concentração de $50 \mu \mathrm{g} / \mathrm{L}$ de cada componente. 


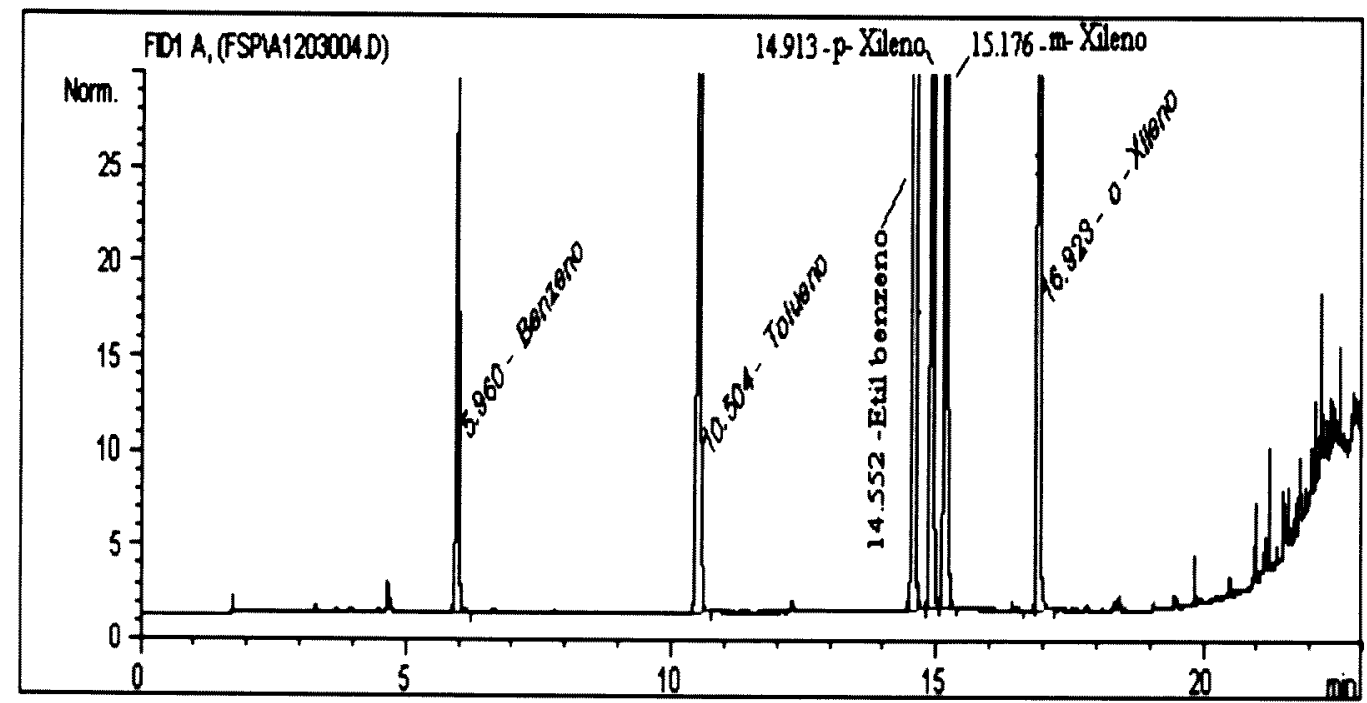

Figura 39 - Cromatograma do padrão de BTEX na concentração de $100 \mu \mathrm{g} / \mathrm{L}$ de cada componente.

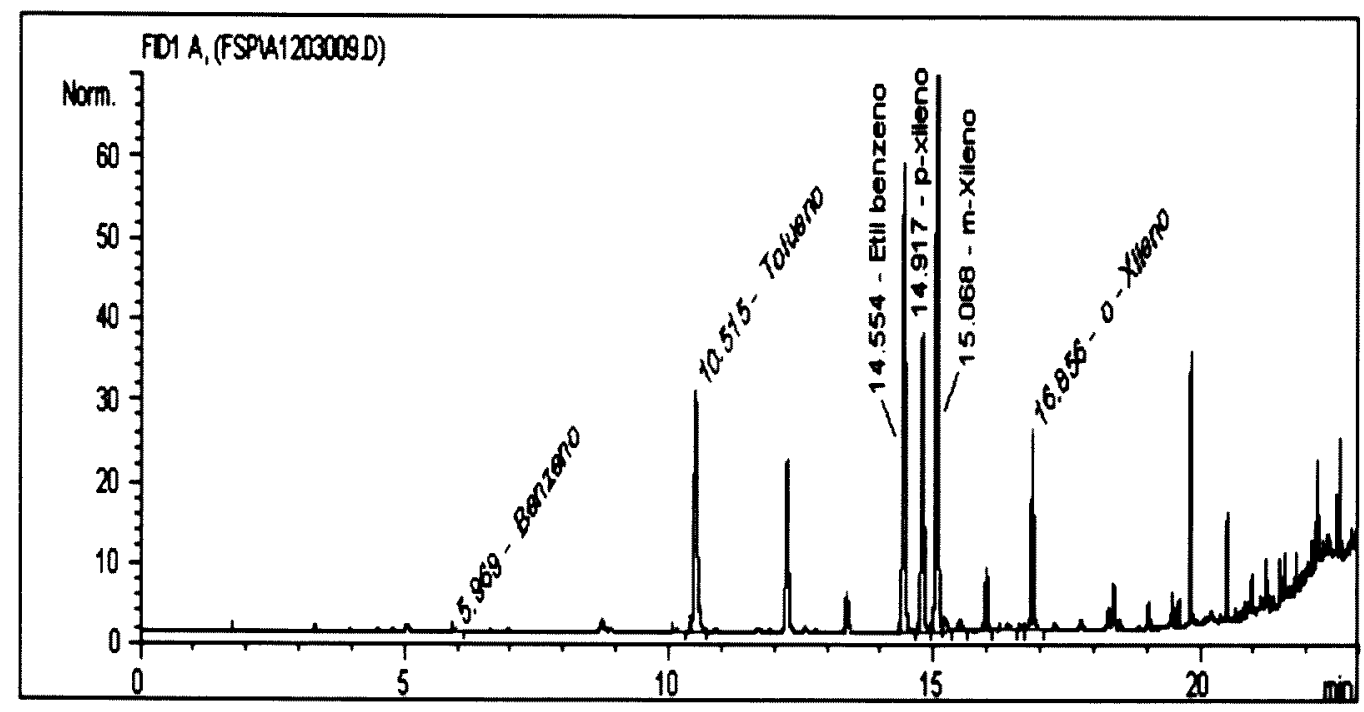

Figura 40 - Cromatograma da análise de BTEX do tanque antes do tratamento fisico-químico. 


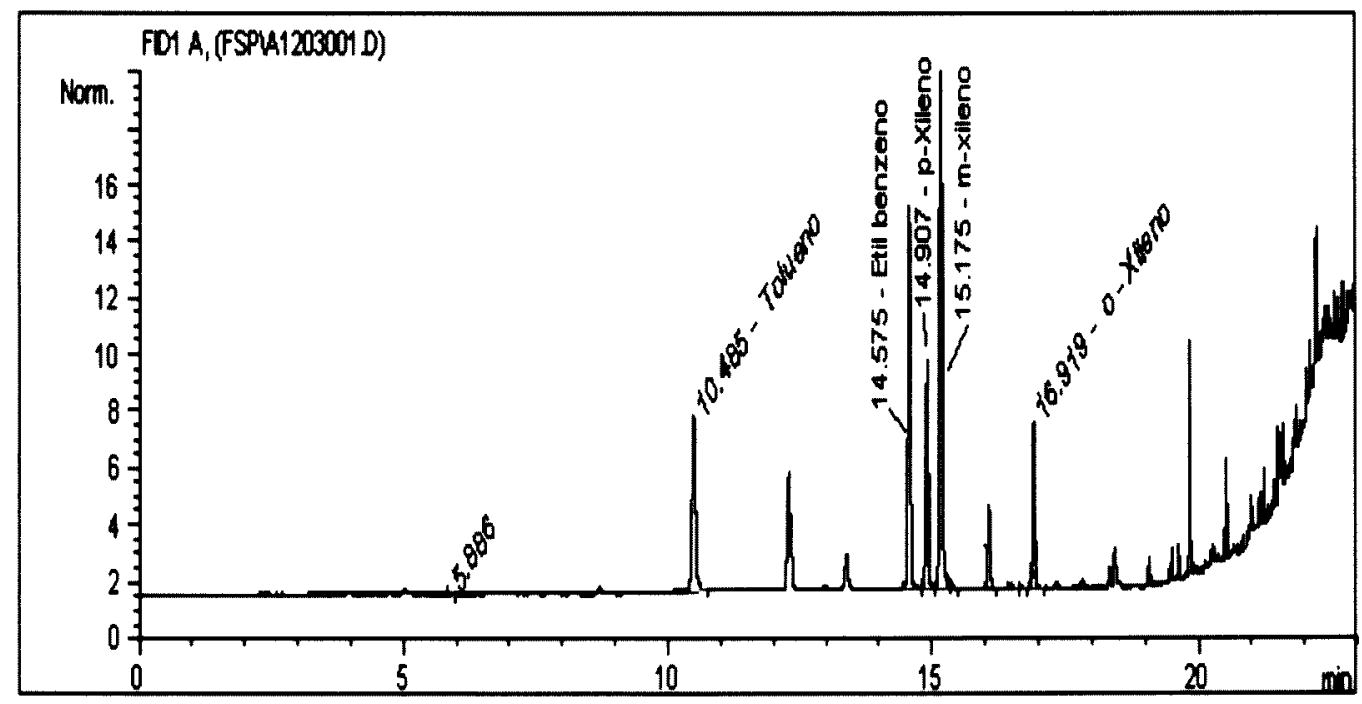

Figura 41 - Cromatograma da análise de BTEX do tanque após o tratamento físico-químico.

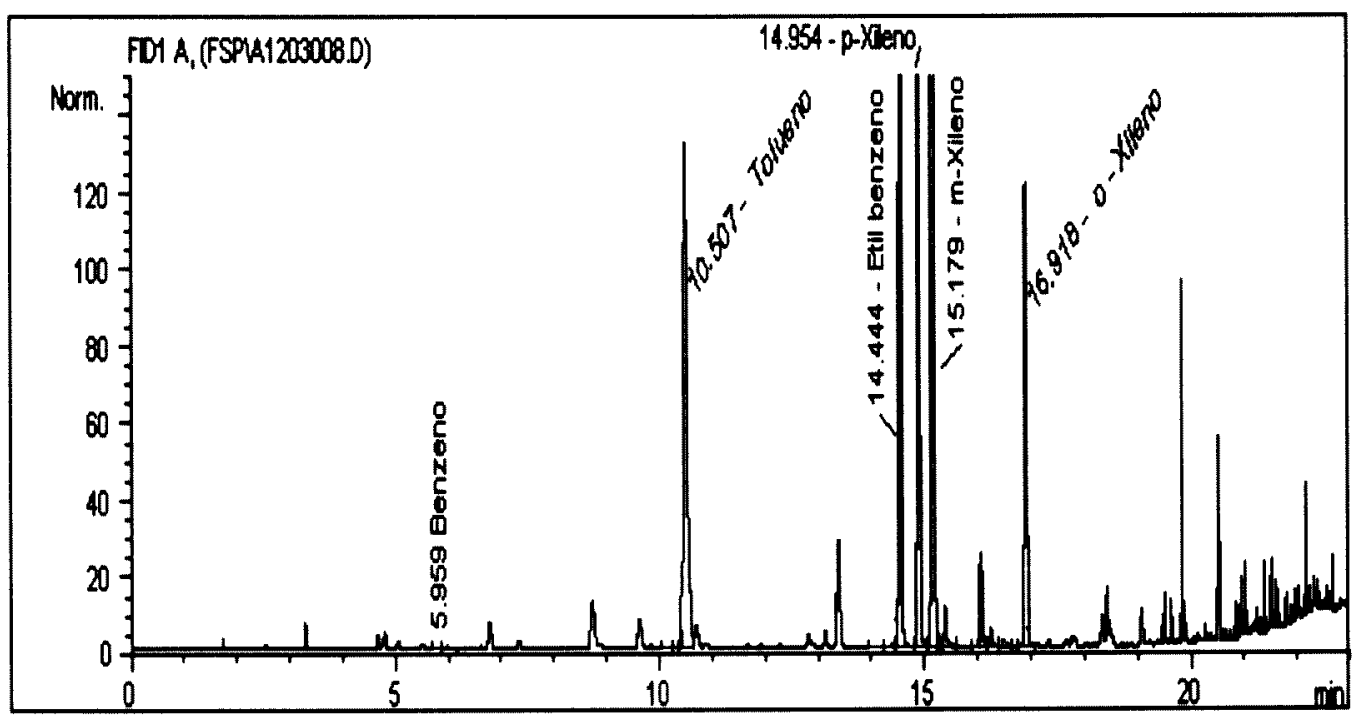

Figura 42 - Cromatograma da análise de BTEX do tanque de equalização. 


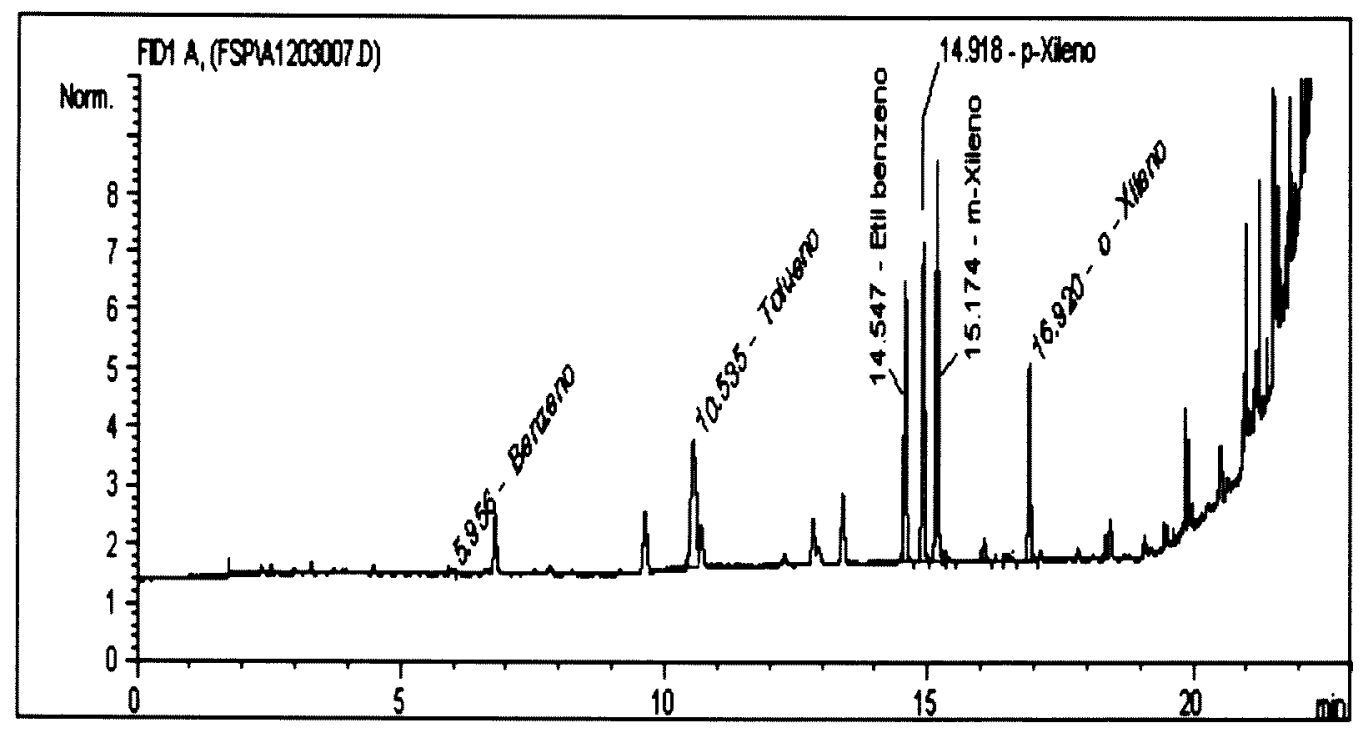

Figura 43 - Cromatograma da análise de BTEX da lagoa de estabilização 1.

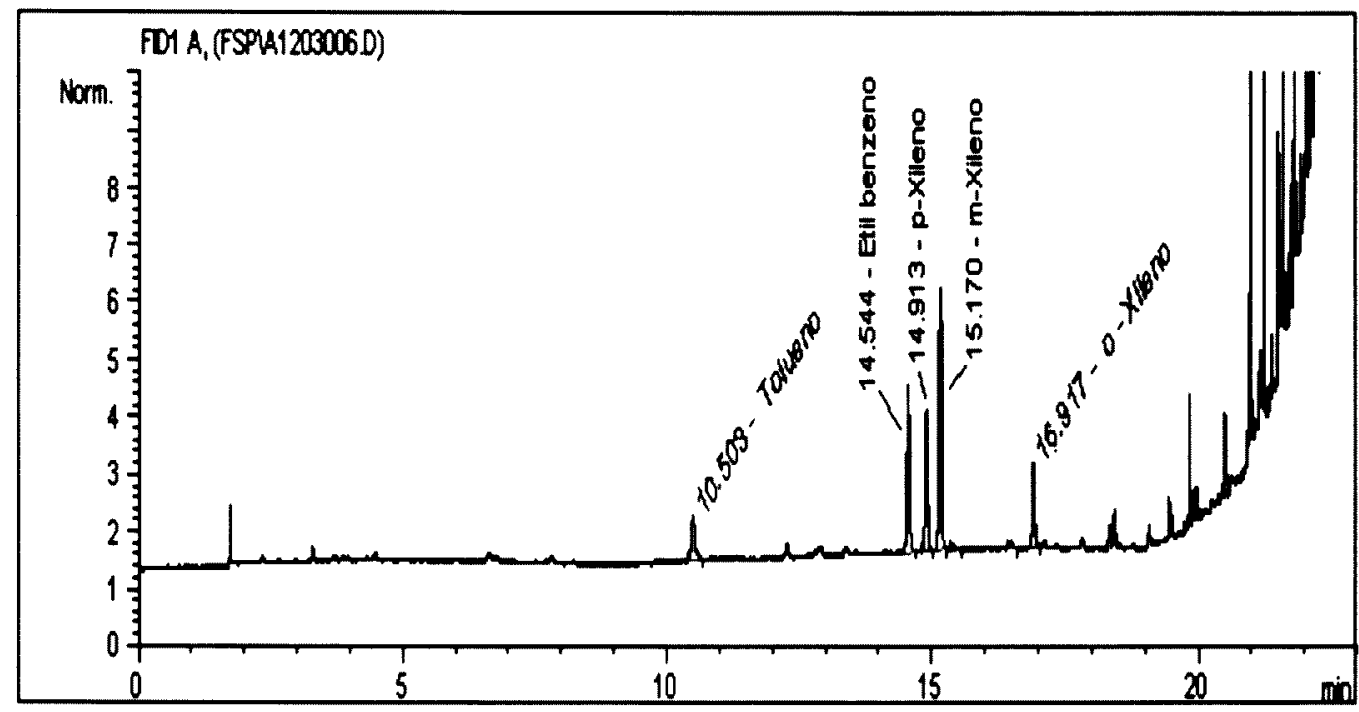

Figura 44 - Cromatograma da análise de BTEX da lagoa de estabilização 2 


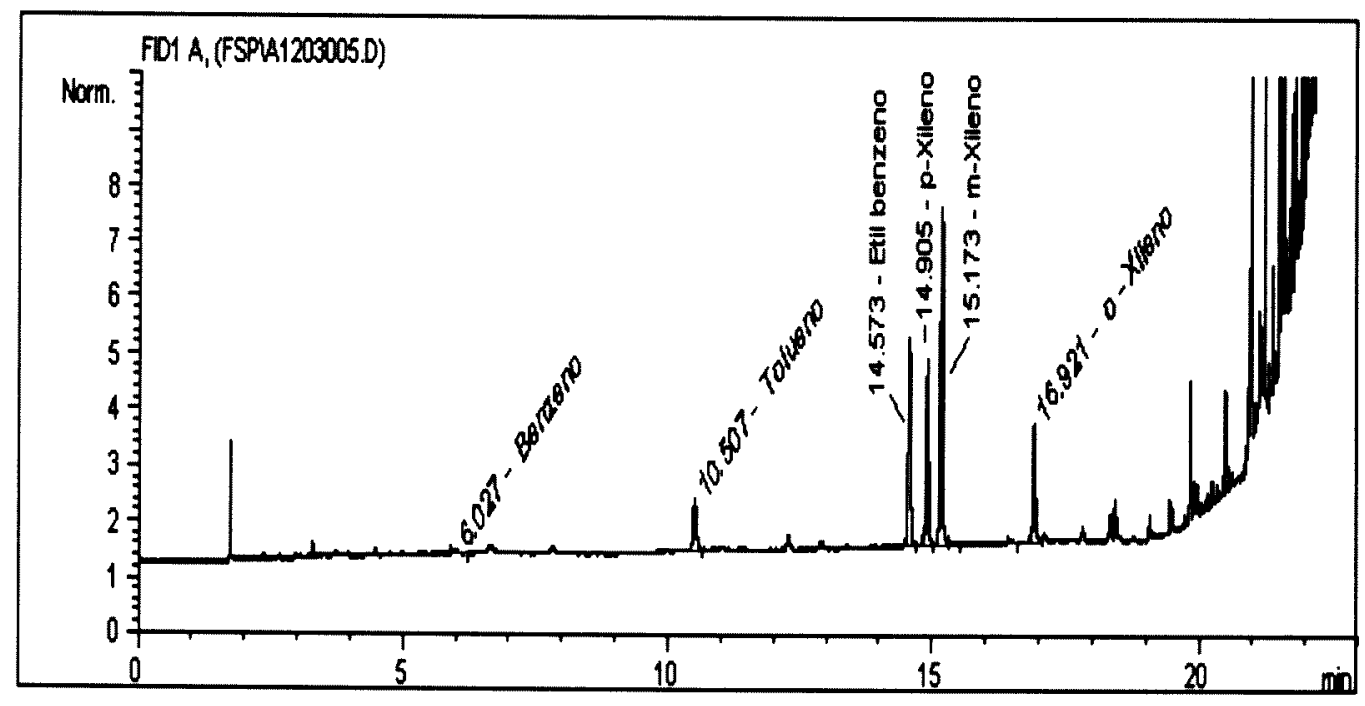

Figura 45 - Cromatograma da análise de BTEX da lagoa de estabilização 3. 
4.4 Teste para avaliar a amostragem do tanque de equalização

O sistema de amostragem adotado para este estudo foi avaliado por meio da retirada de três amostras de $300 \mathrm{~mL}$ cada, a $30 \mathrm{~cm}$ de profundidade da superfície da água do tanque de equalização, em três pontos predeterminados. As amostras, após serem analisadas, foram avaliadas conforme a tabela 10, demonstrando-se que a amostragem utilizada é condizente com o processo aqui estudado.

Tabela 10 - Teste da amostragem do tanque de equalização através de coleta de três amostras de diferentes pontos do tanque (valores expressos em $\mu g / L)$.

\begin{tabular}{|c|c|c|c|c|c|c|}
\hline $\begin{array}{l}\text { Número de } \\
\text { Iniecóes }\end{array}$ & Benzeno & Tolueno & Etil Benzeno & p-Xileno & m-xileno & o-Xileno \\
\hline 1 & ND & 5 & 28 & 21 & 43 & 10 \\
\hline 2 & ND & 5 & 28 & 21 & 43 & 10 \\
\hline 3 & ND & 5 & 24 & 19 & 38 & 10 \\
\hline \multirow{3}{*}{$\begin{array}{c}\text { média - } M \\
\text { Desvio padão - } s \\
\text { Coeficiente de } \\
\text { variação - \% }\end{array}$} & ND & 5 & 27 & 20 & 41 & 10 \\
\hline & & 0 & 2 & 1 & 3 & 0 \\
\hline & & 0 & 9 & 6 & 7 & 0 \\
\hline
\end{tabular}

Limite de quantificaçăo $(\mathrm{LOQ})=5 \mu \mathrm{g} / \mathrm{L}$. - Limite de deteç̧ăo $(\mathrm{LOD})=1 \mu \mathrm{g} / \mathrm{L}$

Compararam-se os três valores de cada um dos componentes do BTEX e calcularam-se a média dos resultados, o desvio-padrão e o coeficiente de variação. $O$ benzeno não foi detectado nas amostras. A média observada para o tolueno foi de (5 $\mu \mathrm{g} / \mathrm{L})$, etil benzeno (27 $\mu \mathrm{g} / \mathrm{L})$, $p$-xileno (20 $\mu \mathrm{g} / \mathrm{L}), m$-xileno $(41 \mu \mathrm{g} / \mathrm{L})$ e o-xileno $(10 \mu \mathrm{g} / \mathrm{L})$. $O$ desvio-padrão variou de 0 a 3 , tendo a menor variação o tolueno e o o-xileno (0) e a maior o $m$-xileno, o 
etil benzeno e o p-xileno (2, 3 e 1 , respectivamente $)$. 0 coeficiente de variação para os compostos variou de 0 a $9 \%$ : para o tolueno e o-xileno foi de $0 \%$; etil benzeno, $8 \%$; $p$-xileno, $6 \%$ e $m$-xileno, $7 \%$. Baseando-se nos resultados, podemos afirmar que o sistema de amostragem adotado demonstrou ser eficiente. 


\subsection{Resultado e discussão do estudo de caso}

\subsubsection{Resultados das análises dos compostos do grupo BTEX após o tratamento de efluentes}

Conforme a estratégia de amostragem descrita anteriormente coletaram-se amostras de água provenientes do tanque de estocagem antes do tratamento físico-químico, após o tratamento físico-quimico, do tanque de equalização e das três lagoas de estabilização, em quatro períodos (verăo, outono, inverno e primavera), de forma a abranger os 12 meses do ano. Seguem abaixo os resultados obtidos de resíduos do grupo BTEX: 
Tabela 11 - Concentração de BTEX ( $\mu g / L)$ das amostras do tanque de estocagem antes do tratamento físico-químico.

\begin{tabular}{|c|c|c|c|c|c|c|c|}
\hline Periodo & Dia & Benzeno & Tolueno & Etil Benzeno & p-XIleno & m-Xileno & o-Xileno \\
\hline Verão 2002 & $\begin{array}{c}\text { 15/Dez } \\
20 / D e z \\
28 / D e z \\
\text { Media } \\
s \\
\text { CV } \% \\
\end{array}$ & $\begin{array}{c}<L O D \\
<L O D \\
<L O D \\
<L O D \\
- \\
-\end{array}$ & $\begin{array}{c}353 \\
324 \\
331 \\
336 \\
15 \\
5 \\
\end{array}$ & $\begin{array}{c}1615 \\
1472 \\
1455 \\
1514 \\
88 \\
6 \\
\end{array}$ & $\begin{array}{c}669 \\
663 \\
586 \\
639 \\
46 \\
7 \\
\end{array}$ & $\begin{array}{c}1565 \\
1677 \\
1459 \\
1567 \\
109 \\
7 \\
\end{array}$ & $\begin{array}{c}621 \\
548 \\
562 \\
577 \\
39 \\
7 \\
\end{array}$ \\
\hline Verão 2003 & $\begin{array}{c}\text { 11/Jan } \\
25 / \text { Jan } \\
08 / \mathrm{FeV} \\
28 / \mathrm{Fev} \\
08 / \mathrm{Mar} \\
29 / \mathrm{Mar} \\
27 / \mathrm{Dez} \\
\text { 04/Jan } \\
\text { Media } \\
\text { s } \\
\text { CV } \%\end{array}$ & $\begin{array}{l}<L O Q \\
<L O Q \\
<L O Q \\
<L O Q \\
<L O Q \\
<L O Q \\
<L O Q \\
<L O Q \\
<L O Q \\
- \\
.\end{array}$ & $\begin{array}{c}714 \\
649 \\
653 \\
659 \\
625 \\
636 \\
648 \\
662 \\
656 \\
26 \\
4\end{array}$ & $\begin{array}{c}433 \\
482 \\
537 \\
458 \\
544 \\
507 \\
450 \\
453 \\
483 \\
42 \\
9\end{array}$ & $\begin{array}{l}299 \\
305 \\
326 \\
229 \\
259 \\
240 \\
248 \\
238 \\
268 \\
37 \\
14\end{array}$ & $\begin{array}{c}699 \\
717 \\
645 \\
557 \\
639 \\
566 \\
597 \\
604 \\
628 \\
58 \\
9\end{array}$ & $\begin{array}{c}143 \\
164 \\
132 \\
157 \\
168 \\
134 \\
143 \\
137 \\
147 \\
14 \\
9\end{array}$ \\
\hline Outono 2003 & $\begin{array}{c}\text { 12/Abr } \\
26 / \mathrm{Abr} \\
10 / \mathrm{Mai} \\
17 / \mathrm{Mai} \\
31 / \mathrm{Mai} \\
\text { 07/Jun } \\
14 / \mathrm{Jun} \\
\text { Media } \\
\text { s } \\
\text { CV } \% \\
\end{array}$ & $\begin{array}{c}<L Q O \\
<L O Q \\
<L O Q \\
<L O Q \\
<L O Q \\
<L O Q \\
<L O Q \\
<L O Q \\
\quad- \\
.\end{array}$ & $\begin{array}{c}20 \\
17 \\
18 \\
12 \\
17 \\
19 \\
17 \\
17 \\
2 \\
15\end{array}$ & $\begin{array}{l}279 \\
258 \\
326 \\
240 \\
235 \\
288 \\
250 \\
268 \\
32 \\
12 \\
\end{array}$ & $\begin{array}{c}198 \\
204 \\
196 \\
189 \\
164 \\
166 \\
164 \\
183 \\
18 \\
10\end{array}$ & $\begin{array}{l}502 \\
494 \\
453 \\
346 \\
384 \\
337 \\
348 \\
409 \\
72 \\
18\end{array}$ & $\begin{array}{l}76 \\
72 \\
60 \\
57 \\
47 \\
49 \\
52 \\
59 \\
11 \\
19\end{array}$ \\
\hline Inverno 2003 & $\begin{array}{c}28 / J u n \\
12 / J u l \\
26 / J u l \\
09 / A g o \\
23 / \text { Ago } \\
06 / \text { Set } \\
23 / \text { Set } \\
\text { Media } \\
\text { s } \\
\text { CV\% } \\
\end{array}$ & $\begin{array}{c}<L O D \\
<L O D \\
<L O D \\
<L O D \\
<L O D \\
<L O D \\
<L O D \\
<L O D \\
\quad . \\
.\end{array}$ & $\begin{array}{c}151 \\
161 \\
152 \\
145 \\
150 \\
143 \\
149 \\
150 \\
6 \\
4 \\
\end{array}$ & $\begin{array}{c}1051 \\
1118 \\
1137 \\
997 \\
983 \\
1102 \\
1200 \\
1084 \\
78 \\
7\end{array}$ & $\begin{array}{c}725 \\
765 \\
739 \\
775 \\
680 \\
650 \\
721 \\
722 \\
45 \\
6\end{array}$ & $\begin{array}{c}1768 \\
1787 \\
1692 \\
1577 \\
1680 \\
1656 \\
1593 \\
1679 \\
80 \\
5\end{array}$ & $\begin{array}{c}287 \\
354 \\
387 \\
340 \\
315 \\
285 \\
273 \\
320 \\
42 \\
13\end{array}$ \\
\hline Primavera 2003 & $\begin{array}{c}11 / \text { Out } \\
31 / \text { Out } \\
\text { 08/Nov } \\
22 / \text { Nov } \\
\text { 06/Dez } \\
\text { 13/Dez } \\
\text { Media } \\
\text { s } \\
\text { CV } \% \\
\end{array}$ & $\begin{array}{c}<L O D \\
<L O D \\
<L O D \\
<L O D \\
<L O D \\
<L O D \\
<L O D \\
\quad- \\
\quad-\end{array}$ & $\begin{array}{c}3563 \\
3762 \\
3286 \\
3262 \\
3560 \\
3483 \\
3486 \\
189 \\
5 \\
\end{array}$ & $\begin{array}{c}2812 \\
2559 \\
2798 \\
2798 \\
2689 \\
2496 \\
2692 \\
136 \\
5 \\
\end{array}$ & $\begin{array}{c}1860 \\
2033 \\
1507 \\
1695 \\
1877 \\
1918 \\
1815 \\
186 \\
10 \\
\end{array}$ & $\begin{array}{c}4599 \\
3967 \\
3766 \\
3480 \\
4289 \\
4145 \\
4041 \\
394 \\
10 \\
\end{array}$ & $\begin{array}{c}1014 \\
1120 \\
1015 \\
997 \\
943 \\
899 \\
998 \\
75 \\
8 \\
\end{array}$ \\
\hline
\end{tabular}

Limite de quantificaçăo (LOQ) $=5 \mu \mathrm{g} / \mathrm{L}$. - Limite de deteç̧ăo (LOD) $=1 \mu \mathrm{g} / \mathrm{L}$. 
Tabela 12 - Concentração de BTEX ( $\mu \mathrm{g} / \mathrm{L})$ das amostras do tanque de estocagem após o tratamento físico-químico.

\begin{tabular}{|c|c|c|c|c|c|c|c|}
\hline Periodo & Dia & Benzeno & Tolueno & Etil Benzeno & p-Xileno & m-Xileno & O-XIleno \\
\hline Verăo 2002 & $\begin{array}{c}\text { 15/Dez } \\
\text { 20/Dez } \\
28 / \mathrm{Dez} \\
\text { Medla } \\
\text { s } \\
\text { CV } \%\end{array}$ & $\begin{array}{c}<L O D \\
<L O D \\
<L O D \\
<L O D \\
\cdot \\
\cdot\end{array}$ & $\begin{array}{c}276 \\
244 \\
266 \\
262 \\
16 \\
6\end{array}$ & $\begin{array}{c}1434 \\
1415 \\
1399 \\
1416 \\
18 \\
1\end{array}$ & $\begin{array}{c}589 \\
563 \\
531 \\
561 \\
29 \\
4\end{array}$ & $\begin{array}{c}1781 \\
1447 \\
1576 \\
1601 \\
168 \\
11\end{array}$ & $\begin{array}{c}586 \\
515 \\
508 \\
536 \\
43 \\
8\end{array}$ \\
\hline Verăo 2003 & $\begin{array}{c}11 / \mathrm{Jan} \\
25 / \mathrm{Jan} \\
08 / \mathrm{FeV} \\
28 / \mathrm{FeV} \\
08 / \mathrm{Mar} \\
29 / \mathrm{Mar} \\
27 / \mathrm{Dez} \\
\text { 04/Jan } \\
\text { Media } \\
\text { s } \\
\text { CV \% }\end{array}$ & $\begin{array}{l}<L O Q \\
<L O Q \\
<L O Q \\
<L O Q \\
<L O Q \\
<L O Q \\
<L O Q \\
<L O Q \\
<L O Q \\
- \\
-\end{array}$ & $\begin{array}{c}485 \\
478 \\
460 \\
458 \\
423 \\
507 \\
452 \\
466 \\
466 \\
25 \\
5\end{array}$ & $\begin{array}{c}369 \\
305 \\
326 \\
389 \\
259 \\
325 \\
346 \\
378 \\
337 \\
43 \\
13\end{array}$ & $\begin{array}{c}202 \\
198 \\
215 \\
176 \\
189 \\
207 \\
178 \\
210 \\
197 \\
15 \\
7\end{array}$ & $\begin{array}{c}532 \\
537 \\
536 \\
557 \\
517 \\
485 \\
497 \\
515 \\
522 \\
23 \\
5\end{array}$ & $\begin{array}{c}123 \\
132 \\
107 \\
114 \\
95 \\
121 \\
98 \\
96 \\
111 \\
14 \\
13\end{array}$ \\
\hline Outono 2003 & $\begin{array}{c}12 / \mathrm{Abr} \\
26 / \mathrm{Abr} \\
\text { 10/Mai } \\
\text { 17/Mai } \\
\text { 31/Mai } \\
07 / \mathrm{Jun} \\
14 / \mathrm{Jun} \\
\text { Media } \\
\text { s } \\
\text { CV } \%\end{array}$ & $\begin{array}{c}<L O Q \\
<L O Q \\
<L O Q \\
<L O Q \\
<L O Q \\
<L O Q \\
<L O Q \\
<L O Q \\
- \\
-\end{array}$ & $\begin{array}{c}22 \\
21 \\
17 \\
15 \\
15 \\
17 \\
18 \\
18 \\
3 \\
15\end{array}$ & $\begin{array}{c}261 \\
257 \\
289 \\
235 \\
235 \\
243 \\
245 \\
252 \\
19 \\
8\end{array}$ & $\begin{array}{c}176 \\
170 \\
182 \\
168 \\
165 \\
167 \\
161 \\
170 \\
7 \\
4\end{array}$ & $\begin{array}{c}389 \\
378 \\
322 \\
415 \\
402 \\
387 \\
382 \\
382 \\
29 \\
8\end{array}$ & $\begin{array}{c}63 \\
69 \\
61 \\
56 \\
48 \\
51 \\
52 \\
57 \\
7 \\
13\end{array}$ \\
\hline Inverno 2003 & $\begin{array}{c}28 / \text { Jun } \\
12 / \text { Jul } \\
26 / J u l \\
09 / \text { Ago } \\
23 / \text { Ago } \\
\text { 06/Set } \\
23 / \text { Set } \\
\text { Media } \\
\text { s } \\
\text { cV } \%\end{array}$ & $\begin{array}{c}<L O D \\
<L O D \\
<L O D \\
<L O D \\
<L O D \\
<L O D \\
<L O D \\
<L O D \\
. \\
.\end{array}$ & $\begin{array}{c}136 \\
141 \\
134 \\
135 \\
146 \\
126 \\
148 \\
138 \\
8 \\
5\end{array}$ & $\begin{array}{c}1011 \\
1026 \\
1127 \\
1125 \\
986 \\
997 \\
1232 \\
1072 \\
92 \\
8\end{array}$ & $\begin{array}{c}735 \\
743 \\
736 \\
779 \\
713 \\
647 \\
694 \\
721 \\
42 \\
6\end{array}$ & $\begin{array}{c}1732 \\
1755 \\
1582 \\
1585 \\
1623 \\
1612 \\
1515 \\
1629 \\
86 \\
5\end{array}$ & \begin{tabular}{l|}
246 \\
324 \\
310 \\
354 \\
331 \\
296 \\
295 \\
308 \\
34 \\
11
\end{tabular} \\
\hline Primavera 2003 & $\begin{array}{c}11 / \text { Out } \\
31 / \text { Out } \\
\text { 08/Nov } \\
22 / \text { Nov } \\
06 / \text { Dez } \\
13 / \text { Dez } \\
\text { Modia } \\
\text { s } \\
\text { CV } \%\end{array}$ & $\begin{array}{c}<L O D \\
<L O D \\
<L O D \\
<L O D \\
<L O D \\
<L O D \\
<L O D \\
- \\
-\end{array}$ & $\begin{array}{c}2150 \\
2145 \\
1915 \\
2102 \\
2229 \\
1957 \\
2083 \\
122 \\
6\end{array}$ & $\begin{array}{c}1723 \\
1649 \\
1667 \\
1557 \\
1592 \\
1575 \\
1627 \\
63 \\
4\end{array}$ & $\begin{array}{c}1128 \\
1047 \\
1289 \\
1087 \\
1075 \\
1012 \\
1106 \\
98 \\
9\end{array}$ & $\begin{array}{c}2506 \\
2472 \\
2576 \\
2265 \\
2436 \\
2439 \\
2449 \\
104 \\
4\end{array}$ & $\begin{array}{c}615 \\
628 \\
577 \\
546 \\
525 \\
537 \\
571 \\
43 \\
7\end{array}$ \\
\hline
\end{tabular}

Limite de quantificaçăo (LOQ) $=5 \mu \mathrm{g} / \mathrm{L}$. - Limite de detecçăo (LOD) $=1 \mu \mathrm{g} / \mathrm{L}$. 
Tabela 13 - Concentração de BTEX ( $\mu \mathrm{g} / \mathrm{L})$ das amostras do tanque de equalização (tratamento biológico).

\begin{tabular}{|c|c|c|c|c|c|c|c|}
\hline Periodo & Dia & Benzeno & Tolueno & Etil Benzeno & p-Xlleno & m-Xileno & o-Xilono \\
\hline Verão 2002 & $\begin{array}{c}\text { 15/Dez } \\
\text { 20/Dez } \\
\text { 28/Dez } \\
\text { Media } \\
\text { s } \\
\text { CV } \% \\
\end{array}$ & $\begin{array}{c}<L O D \\
<L O D \\
<L O D \\
<L O D \\
- \\
-\end{array}$ & $\begin{array}{c}<L O Q \\
<L O Q \\
<L O Q \\
<L O Q \\
\quad- \\
-\end{array}$ & $\begin{array}{c}<\text { LOQ } \\
<\text { LOQ } \\
<\text { LOQ } \\
<\text { LOQ } \\
- \\
-\end{array}$ & $\begin{array}{c}<L O Q \\
<L O Q \\
<L O Q \\
<L O Q \\
-\end{array}$ & $\begin{array}{c}<L O Q \\
<L O Q \\
<L O Q \\
<L O Q \\
-\end{array}$ & $\begin{array}{c}<\text { LOQ } \\
<\text { LOQ } \\
<\text { LOQ } \\
<\text { LOQ } \\
\quad-\end{array}$ \\
\hline Verăo 2003 & $\begin{array}{c}11 / \mathrm{Jan} \\
25 / \mathrm{Jan} \\
08 / \mathrm{Fev} \\
28 / \mathrm{Fev} \\
08 / \mathrm{Mar} \\
29 / \mathrm{Mar} \\
27 / \mathrm{Dez} \\
04 / \mathrm{Jan} \\
\text { Media } \\
\text { s } \\
\text { CV } \%\end{array}$ & $\begin{array}{c}<\mathrm{LOQ} \\
<\mathrm{LOQ} \\
<\mathrm{LOQ} \\
<\mathrm{LOQ} \\
<\mathrm{LOQ} \\
<\mathrm{LOQ} \\
<\mathrm{LOQ} \\
<\mathrm{LOQ} \\
<\mathrm{LOQ} \\
- \\
.\end{array}$ & $\begin{array}{c}235 \\
222 \\
189 \\
199 \\
192 \\
206 \\
176 \\
190 \\
201 \\
19 \\
10\end{array}$ & $\begin{array}{c}16 \\
15 \\
15 \\
13 \\
14 \\
14 \\
13 \\
13 \\
14 \\
1 \\
8\end{array}$ & $\begin{array}{l}90 \\
89 \\
85 \\
86 \\
83 \\
80 \\
84 \\
98 \\
87 \\
6 \\
6\end{array}$ & $\begin{array}{c}211 \\
189 \\
186 \\
180 \\
189 \\
192 \\
177 \\
189 \\
189 \\
10 \\
5\end{array}$ & $\begin{array}{l}60 \\
59 \\
55 \\
57 \\
53 \\
54 \\
52 \\
57 \\
56 \\
3 \\
5\end{array}$ \\
\hline Outono 2003 & $\begin{array}{c}\text { 12/Abr } \\
26 / \mathrm{Abr} \\
10 / \mathrm{Mai} \\
\text { 17/Mai } \\
31 / \mathrm{Mai} \\
\text { 07/Jun } \\
14 / \mathrm{Jun} \\
\text { Medla } \\
\text { s } \\
\text { CV } \% \\
\end{array}$ & $\begin{array}{c}<L O D \\
<L O D \\
<L O D \\
<L O D \\
<L O D \\
<L O D \\
<L O D \\
<L O D \\
\quad- \\
-\end{array}$ & $\begin{array}{l}7 \\
7 \\
5 \\
4 \\
4 \\
4 \\
3 \\
5 \\
2 \\
31\end{array}$ & $\begin{array}{c}10 \\
11 \\
7 \\
10 \\
9 \\
7 \\
8 \\
9 \\
2 \\
17\end{array}$ & $\begin{array}{c}7 \\
8 \\
5 \\
5 \\
7 \\
6 \\
5 \\
6 \\
1 \\
10\end{array}$ & $\begin{array}{c}18 \\
17 \\
18 \\
17 \\
14 \\
15 \\
13 \\
16 \\
2 \\
13\end{array}$ & $\begin{array}{c}<L O Q \\
<L O Q \\
<L O Q \\
<L O Q \\
<L O Q \\
<L O Q \\
<L O Q \\
<L O Q \\
- \\
-\end{array}$ \\
\hline Inverno 2003 & $\begin{array}{c}28 / J u n \\
12 / \text { Jul } \\
26 / J u l \\
09 / \text { Ago } \\
23 / \text { Ago } \\
\text { 06/Set } \\
23 / \text { Set } \\
\text { Media } \\
\text { s } \\
\text { cV \% }\end{array}$ & $\begin{array}{c}<L O D \\
<L O D \\
<L O D \\
<L O D \\
<L O D \\
<L O D \\
<L O D \\
<L O D \\
- \\
-\end{array}$ & $\begin{array}{c}7 \\
5 \\
6 \\
4 \\
5 \\
5 \\
4 \\
5 \\
1 \\
21\end{array}$ & $\begin{array}{c}26 \\
29 \\
30 \\
27 \\
24 \\
25 \\
23 \\
26 \\
3 \\
10\end{array}$ & $\begin{array}{c}22 \\
20 \\
21 \\
19 \\
20 \\
16 \\
21 \\
20 \\
2 \\
10\end{array}$ & $\begin{array}{l}45 \\
42 \\
44 \\
42 \\
39 \\
37 \\
38 \\
41 \\
3 \\
7\end{array}$ & $\begin{array}{c}12 \\
10 \\
9 \\
8 \\
10 \\
7 \\
8 \\
9 \\
2 \\
19\end{array}$ \\
\hline Primavera 2003 & $\begin{array}{c}11 / \text { Out } \\
31 / \text { Out } \\
08 / \text { Nov } \\
22 / \text { Nov } \\
06 / \text { Dez } \\
13 / \text { Dez } \\
\text { Modia } \\
\text { s } \\
\text { CV } \%\end{array}$ & $\begin{array}{c}<L O Q \\
<L O Q \\
<L O Q \\
<L O Q \\
<L O Q \\
<L O Q \\
<L O Q \\
- \\
-\end{array}$ & $\begin{array}{c}115 \\
118 \\
98 \\
97 \\
118 \\
102 \\
108 \\
10 \\
9 \\
\end{array}$ & $\begin{array}{c}119 \\
117 \\
113 \\
96 \\
98 \\
95 \\
106 \\
11 \\
10\end{array}$ & $\begin{array}{c}79 \\
80 \\
76 \\
74 \\
71 \\
75 \\
76 \\
3 \\
4\end{array}$ & $\begin{array}{c}180 \\
178 \\
159 \\
161 \\
176 \\
178 \\
172 \\
9 \\
5\end{array}$ & $\begin{array}{c}48 \\
51 \\
42 \\
37 \\
37 \\
44 \\
43 \\
6 \\
13\end{array}$ \\
\hline
\end{tabular}

Limite de quantificaçăo (LOQ) $=5 \mu \mathrm{g} / \mathrm{L}$. - Limite de detecçăo (LOD) $=1 \mu \mathrm{g} / \mathrm{L}$. 
Tabela 14 - Concentração de BTEX ( $\mu g / L)$ das amostras da lagoa de estabilização 1 (tratamento biológico).

\begin{tabular}{|c|c|c|c|c|c|c|c|}
\hline Período & Dia & Benzeno & Tolueno & Etil Benzeno & p-XIleno & m-XIIeno & o-XIleno \\
\hline Verzo 2002 & $\begin{array}{l}\text { 15/Dez } \\
20 / \text { Dez } \\
28 / \mathrm{Dez} \\
\text { Media } \\
\text { s } \\
\text { CV } \% \\
\end{array}$ & $\begin{array}{c}<L O D \\
<L O D \\
<L O D \\
<L O D \\
\cdot \\
.\end{array}$ & $\begin{array}{c}<L O Q \\
<L O Q \\
<L O Q \\
<L O Q \\
- \\
-\end{array}$ & $\begin{array}{c}10 \\
9 \\
9 \\
9 \\
0,6 \\
6\end{array}$ & $\begin{array}{c}9 \\
8 \\
9 \\
9 \\
0,6 \\
6\end{array}$ & $\begin{array}{c}17 \\
15 \\
14 \\
15 \\
2 \\
10\end{array}$ & $\begin{array}{c}<\angle O Q \\
<\angle O Q \\
<L O Q \\
<L O Q \\
- \\
.\end{array}$ \\
\hline Verto 2003 & $\begin{array}{c}\text { 11/Jan } \\
25 / \mathrm{Jan} \\
\text { 08/Fev } \\
28 / \mathrm{FeV} \\
\text { 08/Mar } \\
29 / \mathrm{Mar} \\
27 / \mathrm{Dez} \\
04 / \mathrm{Jan} \\
\text { Media } \\
\text { s } \\
\text { CV } \% \\
\end{array}$ & $\begin{array}{l}<L O D \\
<L O D \\
<L O D \\
<L O D \\
<L O D \\
<L O D \\
<L O D \\
<L O D \\
<L O D \\
. \\
.\end{array}$ & $\begin{array}{l}<\angle O Q \\
<L O Q \\
<L O Q \\
<L O Q \\
<L O Q \\
<L O Q \\
<L O Q \\
<L O Q \\
<L O Q \\
\quad- \\
.\end{array}$ & $\begin{array}{l}<L O Q \\
<L O Q \\
<L O Q \\
<L O Q \\
<L O Q \\
<L O Q \\
<L O Q \\
<L O Q \\
<L O Q \\
\quad . \\
.\end{array}$ & $\begin{array}{c}<\mathrm{LOQ} \\
<\mathrm{LOQ} \\
<\mathrm{LOQ} \\
<\mathrm{LOQ} \\
<\mathrm{LOQ} \\
<\mathrm{LOQ} \\
<\mathrm{LOQ} \\
<\mathrm{LOQ} \\
<\mathrm{LOQ} \\
- \\
-\end{array}$ & $\begin{array}{c}<L O Q \\
<L O Q \\
<L O Q \\
<L O Q \\
<L O Q \\
<L O Q \\
<L O Q \\
<L O Q \\
<L O Q \\
= \\
.\end{array}$ & $\begin{array}{c}<\text { LOQ } \\
<\text { LOQ } \\
<\text { LOQ } \\
<\text { LOQ } \\
<\text { LOQ } \\
<\text { LOQ } \\
<\text { LOQ } \\
<\angle O Q \\
<\text { LOQ } \\
- \\
.\end{array}$ \\
\hline Outono 2003 & $\begin{array}{c}12 / \mathrm{Abr} \\
26 / \mathrm{Abr} \\
10 / \mathrm{Mai} \\
17 / \mathrm{Mai} \\
31 / \mathrm{Mai} \\
07 / \mathrm{Jun} \\
14 / \mathrm{Jun} \\
\text { Media } \\
5 \\
\mathrm{CV} \% \\
\end{array}$ & $\begin{array}{l}<L O D \\
<L O D \\
<L O D \\
<L O D \\
<L O D \\
<L O D \\
<L O D \\
<L O D \\
\quad . \\
.\end{array}$ & $\begin{array}{c}10 \\
9 \\
9 \\
11 \\
9 \\
8 \\
9 \\
9 \\
1 \\
11 \\
\end{array}$ & $\begin{array}{c}7 \\
6 \\
5 \\
4 \\
6 \\
7 \\
6 \\
6 \\
1 \\
19 \\
\end{array}$ & $\begin{array}{c}5 \\
4 \\
4 \\
5 \\
5 \\
6 \\
4 \\
5 \\
0,8 \\
15 \\
\end{array}$ & $\begin{array}{c}8 \\
10 \\
9 \\
9 \\
8 \\
7 \\
11 \\
9 \\
3 \\
23\end{array}$ & $\begin{array}{c}<\text { LOQ } \\
<\text { LOQ } \\
<\text { LOQ } \\
<\text { LOQ } \\
<\text { LOQ } \\
<\text { LOQ } \\
<\text { LOQ } \\
<\text { LOQ } \\
- \\
-\end{array}$ \\
\hline Inverno 2003 & $\begin{array}{c}28 / \text { Jun } \\
12 / \text { Jul } \\
26 / \text { Jul } \\
09 / \text { Ago } \\
23 / \text { Ago } \\
06 / \text { Set } \\
23 / \text { Set } \\
\text { Medla } \\
\text { s } \\
\text { CV } \% \\
\end{array}$ & $\begin{array}{l}<L O D \\
<L O D \\
<L O D \\
<L O D \\
<L O D \\
<L O D \\
<L O D \\
<L O D \\
- \\
-\end{array}$ & $\begin{array}{l}70 \\
71 \\
67 \\
72 \\
73 \\
70 \\
69 \\
70 \\
2 \\
3 \\
\end{array}$ & $\begin{array}{l}20 \\
22 \\
21 \\
24 \\
26 \\
25 \\
24 \\
23 \\
2 \\
9 \\
\end{array}$ & $\begin{array}{c}28 \\
24 \\
25 \\
24 \\
26 \\
26 \\
28 \\
26 \\
2 \\
6 \\
\end{array}$ & $\begin{array}{l}47 \\
44 \\
45 \\
47 \\
43 \\
45 \\
46 \\
45 \\
1 \\
2 \\
\end{array}$ & $\begin{array}{l}4 \\
5 \\
4 \\
7 \\
6 \\
8 \\
7 \\
6 \\
2 \\
26 \\
\end{array}$ \\
\hline Primavera 2003 & $\begin{array}{c}11 / \text { Out } \\
31 / \text { Out } \\
08 / \text { Nov } \\
22 / \text { Nov } \\
06 / D e z \\
13 / \mathrm{Dez} \\
\text { Media } \\
\text { s } \\
\text { CV } \%\end{array}$ & $\begin{array}{c}<L O D \\
<L O D \\
<L O D \\
<L O D \\
<L O D \\
<L O D \\
<L O D \\
. \\
.\end{array}$ & $\begin{array}{l}<\angle O Q \\
<L O Q \\
<L O Q \\
<L O Q \\
<L O Q \\
<L O Q \\
<L O Q \\
- \\
-\end{array}$ & $\begin{array}{l}<\angle O Q \\
<\angle O Q \\
<L O Q \\
<L O Q \\
<L O Q \\
<L O Q \\
<L O Q \\
- \\
-\end{array}$ & $\begin{array}{c}<\text { LOQ } \\
<L O Q \\
<L O Q \\
<L O Q \\
<L O Q \\
<L O Q \\
<L O Q \\
\quad-\end{array}$ & $\begin{array}{l}<\angle O Q \\
<L O Q \\
<L O Q \\
<L O Q \\
<L O Q \\
<L O Q \\
<L O Q \\
. \\
.\end{array}$ & $\begin{array}{c}<\text { LOD } \\
<L O D \\
<L O D \\
<L O D \\
<L O D \\
<\text { LOD } \\
<\text { LOD } \\
\quad- \\
-\end{array}$ \\
\hline
\end{tabular}

Limite de quantificaçăo (LOQ) = $5 \mu \mathrm{g} / \mathrm{L}$. - Limite de deteçăo (LOD) = $1 \mu \mathrm{g} / \mathrm{L}$. 
Tabela 15 - Concentração de BTEX ( $\mu \mathrm{g} / \mathrm{L})$ das amostras da lagoa de estabilização 2 (tratamento biológico).

\begin{tabular}{|c|c|c|c|c|c|c|c|}
\hline Perlodo & Dia & Benzeno & Tolueno & Etil Benzeno & p-Xlleno & $m$-XIleno & O-XIleno \\
\hline Verto 2002 & $\begin{array}{c}\text { 15/Dez } \\
\text { 20/Dez } \\
28 / \text { Dez } \\
\text { Media } \\
\text { s } \\
\text { cV } \%\end{array}$ & $\begin{array}{c}<L O D \\
<L O D \\
<L O D \\
<L O D \\
- \\
\quad-\end{array}$ & $\begin{array}{c}5 \\
4 \\
6 \\
5 \\
1 \\
20\end{array}$ & $\begin{array}{c}<\angle O Q \\
<\angle O Q \\
<L O Q \\
<\angle O Q \\
- \\
-\end{array}$ & $\begin{array}{c}<\angle O Q \\
<\angle O Q \\
<L O Q \\
<L O Q \\
= \\
\cdot\end{array}$ & $\begin{array}{l}<\angle O Q \\
<\angle O Q \\
<\angle O Q \\
<\angle O Q \\
\quad \cdot \\
.\end{array}$ & $\begin{array}{l}<\angle O Q \\
<\angle O Q \\
<L O Q \\
<L O Q \\
\quad \cdot \\
\quad\end{array}$ \\
\hline Veräo 2003 & $\begin{array}{c}11 / \mathrm{Jan} \\
25 / \mathrm{Jan} \\
\text { 08/Fev } \\
28 / \mathrm{Fev} \\
\text { 08/Mar } \\
29 / \mathrm{Mar} \\
27 / \mathrm{Dez} \\
\text { 04/Jan } \\
\text { Media } \\
\text { s } \\
\text { CV\% }\end{array}$ & $\begin{array}{l}<L O D \\
<L O D \\
<L O D \\
<L O D \\
<L O D \\
<L O D \\
<L O D \\
<L O D \\
<L O D \\
.\end{array}$ & $\begin{array}{c}<L O Q \\
<L O Q \\
<L O Q \\
<L O Q \\
<L O Q \\
<L O Q \\
<L O Q \\
<L O Q \\
<L O Q \\
- \\
.\end{array}$ & $\begin{array}{l}<\angle O Q \\
<\angle O Q \\
<\angle O Q \\
<\angle O Q \\
<L O Q \\
<\angle O Q \\
<L O Q \\
<L O Q \\
<L O Q \\
- \\
-\end{array}$ & $\begin{array}{c}<\angle O Q \\
<L O Q \\
<L O Q \\
<L O Q \\
<L O Q \\
<L O Q \\
<L O Q \\
<L O Q \\
<L O Q \\
- \\
.\end{array}$ & $\begin{array}{l}<\angle O Q \\
<\angle O Q \\
<L O Q \\
<L O Q \\
<L O Q \\
<L O Q \\
<L O Q \\
<L O Q \\
<L O Q \\
- \\
-\end{array}$ & $\begin{array}{c}<\angle O Q \\
<\angle O Q \\
<\angle O Q \\
<\angle O Q \\
<L O Q \\
<\angle O Q \\
<L O Q \\
<L O Q \\
<L O Q \\
\quad \\
.\end{array}$ \\
\hline Outono 2003 & $\begin{array}{l}12 / \mathrm{Abr} \\
26 / \mathrm{Abr} \\
10 / \mathrm{Mai} \\
17 / \mathrm{Mai} \\
31 / \mathrm{Mai} \\
07 / \mathrm{Jun} \\
14 / \mathrm{Jun} \\
\text { Medla } \\
\mathrm{s} \\
\mathrm{CV} \%\end{array}$ & $\begin{array}{c}<L O D \\
<L O D \\
<L O D \\
<L O D \\
<L O D \\
<L O D \\
<L O D \\
<L O D \\
- \\
.\end{array}$ & $\begin{array}{c}10 \\
9 \\
10 \\
12 \\
12 \\
9 \\
9 \\
10 \\
1 \\
13\end{array}$ & $\begin{array}{c}9 \\
7 \\
7 \\
8 \\
7 \\
6 \\
7 \\
7 \\
1 \\
14\end{array}$ & $\begin{array}{c}6 \\
5 \\
5 \\
4 \\
7 \\
4 \\
6 \\
5 \\
1 \\
22\end{array}$ & $\begin{array}{c}11 \\
13 \\
11 \\
12 \\
10 \\
9 \\
13 \\
11 \\
1 \\
14\end{array}$ & $\begin{array}{l}<\angle O Q \\
<L O Q \\
<L O Q \\
<L O Q \\
<L O Q \\
<L O Q \\
<L O Q \\
<L O Q \\
-\end{array}$ \\
\hline Inverno 2003 & $\begin{array}{c}28 / \mathrm{Jun} \\
12 / \mathrm{Jul} \\
26 / \mathrm{Jul} \\
09 / \mathrm{Ago} \\
23 / \mathrm{Ago} \\
06 / \mathrm{Set} \\
23 / \mathrm{Set} \\
\text { Media } \\
\text { s } \\
\text { cV } \%\end{array}$ & $\begin{array}{c}<L O D \\
<L O D \\
<L O D \\
<L O D \\
<L O D \\
<L O D \\
<L O D \\
<L O D \\
- \\
.\end{array}$ & $\begin{array}{l}71 \\
69 \\
71 \\
68 \\
65 \\
65 \\
67 \\
68 \\
2 \\
4\end{array}$ & $\begin{array}{l}19 \\
17 \\
18 \\
16 \\
17 \\
18 \\
16 \\
17 \\
1 \\
7\end{array}$ & $\begin{array}{c}17 \\
18 \\
21 \\
16 \\
15 \\
15 \\
17 \\
17 \\
2 \\
12\end{array}$ & $\begin{array}{l}28 \\
29 \\
30 \\
33 \\
29 \\
31 \\
31 \\
30 \\
2 \\
5\end{array}$ & $\begin{array}{c}<\angle O Q \\
<\angle O Q \\
<\angle O Q \\
<\angle O Q \\
<\angle O Q \\
<L O Q \\
<\angle O Q \\
<\angle O Q \\
- \\
-\end{array}$ \\
\hline Primavera 2003 & $\begin{array}{c}11 / \text { Out } \\
31 / \text { Out } \\
\text { O8/Nov } \\
22 / \text { Nov } \\
06 / \mathrm{Dez} \\
13 / \mathrm{Dez} \\
\text { Media } \\
\text { CV } \%\end{array}$ & $\begin{array}{c}<L O D \\
<L O D \\
<L O D \\
<L O D \\
<L O D \\
<L O D \\
<L O D \\
. \\
.\end{array}$ & $\begin{array}{c}<\angle O Q \\
<\angle O Q \\
<\angle O Q \\
<\angle O Q \\
<\angle O Q \\
<\angle O Q \\
<\angle O Q \\
- \\
-\end{array}$ & $\begin{array}{c}<\angle O Q \\
<L O Q \\
<L O Q \\
<L O Q \\
<L O Q \\
<L O Q \\
<L O Q \\
. \\
.\end{array}$ & $\begin{array}{c}<\angle O Q \\
<\angle O Q \\
<L O Q \\
<L O Q \\
<L O Q \\
<L O Q \\
<L O Q \\
- \\
.\end{array}$ & $\begin{array}{c}<\angle O Q \\
<\angle O Q \\
<\angle O Q \\
<\angle O Q \\
<\angle O Q \\
<L O Q \\
<L O Q \\
. \\
.\end{array}$ & $\begin{array}{c}<\angle O Q \\
<\angle O Q \\
<L O Q \\
<L O Q \\
<L O Q \\
<L O Q \\
<L O Q \\
- \\
-\end{array}$ \\
\hline
\end{tabular}

Limite de quantificaçăo (LOQ) $=5 \mu g / L$. - Limite de deteç̧ăo $(L O D)=1 \mu g / L$. 
Tabela 16 - Concentração de BTEX ( $\mu \mathrm{g} / \mathrm{L})$ das amostras da lagoa de estabilização 3 (tratamento biológico).

\begin{tabular}{|c|c|c|c|c|c|c|c|}
\hline Periodo & Dia & Benzeno & Tolueno & Etll Benzeno & p-Xileno & m-XIleno & o-XIleno \\
\hline Verăo 2002 & $\begin{array}{c}\text { 15/Dez } \\
20 / \text { Dez } \\
28 / \text { Dez } \\
\text { Media } \\
\text { s } \\
\text { CV } \%\end{array}$ & $\begin{array}{c}<L O D \\
<L O D \\
<L O D \\
<L O D \\
- \\
-\end{array}$ & $\begin{array}{c}<L O Q \\
<L O Q \\
<L O Q \\
<L O Q \\
\quad \cdot \\
\quad\end{array}$ & $\begin{array}{c}<L O Q \\
<L O Q \\
<L O Q \\
<L O Q \\
-\end{array}$ & $\begin{array}{c}<L O Q \\
<L O Q \\
<L O Q \\
<L O Q \\
- \\
-\end{array}$ & $\begin{array}{c}<\angle O Q \\
<L O Q \\
<L O Q \\
<L O Q \\
- \\
-\end{array}$ & $\begin{array}{c}<\angle O Q \\
<\angle O Q \\
<\angle O Q \\
<\angle O Q \\
- \\
-\end{array}$ \\
\hline Verăo 2003 & $\begin{array}{c}11 / \mathrm{Jan} \\
25 / \mathrm{Jan} \\
08 / \mathrm{Fev} \\
28 / \mathrm{Fev} \\
08 / \mathrm{Mar} \\
29 / \mathrm{Mar} \\
27 / \mathrm{Dez} \\
04 / \mathrm{Jan} \\
\text { Medla } \\
\text { s } \\
\text { CV } \% \\
\end{array}$ & $\begin{array}{c}<L O D \\
<L O D \\
<L O D \\
<L O D \\
<L O D \\
<L O D \\
<L O D \\
<L O D \\
<L O D \\
- \\
-\end{array}$ & $\begin{array}{c}<L O Q \\
<L O Q \\
<L O Q \\
<L O Q \\
<L O Q \\
<L O Q \\
<L O Q \\
<L O Q \\
<L O Q \\
. \\
.\end{array}$ & $\begin{array}{l}<\angle O Q \\
<L O Q \\
<L O Q \\
<L O Q \\
<L O Q \\
<L O Q \\
<L O Q \\
<L O Q \\
<L O Q \\
\quad-\end{array}$ & $\begin{array}{c}<\angle O Q \\
<\angle O Q \\
<L O Q \\
<L O Q \\
<L O Q \\
<L O Q \\
<L O Q \\
<L O Q \\
<L O Q \\
- \\
-\end{array}$ & $\begin{array}{c}<L O Q \\
<L O Q \\
<L O Q \\
<L O Q \\
<L O Q \\
<L O Q \\
<L O Q \\
<L O Q \\
<L O Q \\
-\end{array}$ & $\begin{array}{c}<\angle O Q \\
<L O Q \\
<\angle O Q \\
<\angle O Q \\
<L O Q \\
<L O Q \\
<L O Q \\
<L O Q \\
<L O Q \\
. \\
.\end{array}$ \\
\hline Outono 2003 & $\begin{array}{c}12 / \mathrm{Abr} \\
26 / \mathrm{Abr} \\
10 / \mathrm{Mai} \\
17 / \mathrm{Mai} \\
31 / \mathrm{Mai} \\
07 / \mathrm{Jun} \\
14 / \mathrm{Jun} \\
\text { Modia } \\
s \\
\mathrm{cV} \%\end{array}$ & $\begin{array}{l}<L O D \\
<L O D \\
<L O D \\
<L O D \\
<L O D \\
<L O D \\
<L O D \\
<L O D \\
- \\
-\end{array}$ & $\begin{array}{c}<L O Q \\
<L O Q \\
<L O Q \\
<L O Q \\
<L O Q \\
<L O Q \\
<L O Q \\
<L O Q \\
- \\
.\end{array}$ & $\begin{array}{c}<\text { LOQ } \\
<\text { LOQ } \\
<\text { LOQ } \\
<\text { LOQ } \\
<\text { LOQ } \\
<\text { LOQ } \\
<\text { LOQ } \\
<\text { LOQ } \\
- \\
.\end{array}$ & $\begin{array}{c}<L O Q \\
<L O Q \\
<L O Q \\
<L O Q \\
<L O Q \\
<L O Q \\
<L O Q \\
<L O Q \\
- \\
-\end{array}$ & $\begin{array}{l}6 \\
7 \\
9 \\
5 \\
6 \\
5 \\
5 \\
6 \\
2 \\
24\end{array}$ & $\begin{array}{c}<\mathrm{LOQ} \\
<\mathrm{LOQ} \\
<\mathrm{LOQ} \\
<\mathrm{LOQ} \\
<\mathrm{LOQ} \\
<\mathrm{LOQ} \\
<\mathrm{LOQ} \\
<\mathrm{LOQ} \\
- \\
.\end{array}$ \\
\hline Inverno 2003 & $\begin{array}{c}28 / \mathrm{Jun} \\
12 / \mathrm{Jul} \\
26 / \mathrm{Jul} \\
09 / \mathrm{Ago} \\
23 / \mathrm{AgO} \\
06 / \mathrm{Set} \\
23 / \mathrm{Set} \\
\text { Medla } \\
\text { s } \\
\text { CV } \%\end{array}$ & $\begin{array}{l}<L O D \\
<L O D \\
<L O D \\
<L O D \\
<L O D \\
<L O D \\
<L O D \\
<L O D \\
\quad- \\
-\end{array}$ & $\begin{array}{l}52 \\
53 \\
55 \\
49 \\
52 \\
49 \\
47 \\
51 \\
3 \\
5\end{array}$ & $\begin{array}{l}10 \\
11 \\
12 \\
15 \\
13 \\
12 \\
11 \\
12 \\
12 \\
14\end{array}$ & $\begin{array}{c}14 \\
15 \\
13 \\
11 \\
13 \\
12 \\
12 \\
13 \\
1 \\
10\end{array}$ & $\begin{array}{l}22 \\
22 \\
19 \\
20 \\
21 \\
23 \\
22 \\
21 \\
1 \\
7\end{array}$ & $\begin{array}{c}<\text { LOQ } \\
<\angle O Q \\
<L O Q \\
<L O Q \\
<L O Q \\
<L O Q \\
<L O Q \\
<L O Q \\
- \\
.\end{array}$ \\
\hline Primavera 2003 & $\begin{array}{c}\text { 11/Out } \\
31 / \text { Out } \\
08 / \text { Nov } \\
22 / \text { Nov } \\
\text { 06/Dez } \\
\text { 13/Dez } \\
\text { Media } \\
\text { s } \\
\text { CV } \%\end{array}$ & $\begin{array}{l}<L O D \\
<L O D \\
<L O D \\
<L O D \\
<L O D \\
<L O D \\
<L O D \\
- \\
.\end{array}$ & $\begin{array}{c}<\angle O Q \\
<\angle O Q \\
<L O Q \\
<L O Q \\
<L O Q \\
<L O Q \\
<L O Q \\
- \\
.\end{array}$ & $\begin{array}{c}<\angle O Q \\
<L O Q \\
<L O Q \\
<L O Q \\
<L O Q \\
<L O Q \\
<L O Q \\
- \\
.\end{array}$ & $\begin{array}{c}<L O Q \\
<L O Q \\
<L O Q \\
<L O Q \\
<L O Q \\
<L O Q \\
<L O Q \\
-\end{array}$ & $\begin{array}{c}<L O Q \\
<L O Q \\
<L O Q \\
<L O Q \\
<L O Q \\
<L O Q \\
<L O Q \\
- \\
-\end{array}$ & $\begin{array}{c}<L O Q \\
<L O Q \\
<L O Q \\
<L O Q \\
<L O Q \\
<L O Q \\
<L O Q \\
\quad-\end{array}$ \\
\hline
\end{tabular}

Limite de quantificaçăo (LOQ) $=5 \mu g / L$. - Limite de detecçăo $(L O D)=1 \mu g / L$. 


\subsubsection{Avaliação da biodegradabilidade dos compostos do grupo BTEX por período do ano, após o tratamento de efluentes}

0 tratamento de efluentes industriais tem por objetivo a eliminação de matéria orgânica e também de substâncias nocivas ao meio ambiente e seres humanos. Os processos de tratamento de efluentes industriais foram desenvolvidos baseados nos processos naturais, conforme apresentado anteriormente. $O$ processo de tratamento físico-químico e o biológico são os mais utilizados. Entretanto, dependendo da concentraçăo das substâncias tóxicas presentes, é necessário aplicar outras técnicas de tratamento, mais especificas. No relatório EPA-BDAT (1994b), apresenta uma discussão ampla e direta de várias técnicas que podem ser aplicadas em tratamentos de substâncias orgânicas presentes em efluentes ou de outros tipos de residuos perigosos.

A concentração e o tipo de constituinte presente no efluente geralmente determinam qual será a técnica a ser aplicada. Por exemplo, algumas técnicas são mais apropriadas para tratamento de resíduos com relativa concentraçăo de constituintes orgânicos (acima de 1\%); entretanto, outras são mais adequadas para baixas concentraçz̃es (EPA-BDAT, 2000).

O sistema de tratamento de efluentes aqui estudado está preparado para processar concentraçð̌es de matéria orgânica inferiores a $3 \%$. Entretanto, para que não houvesse saturação do sistema, realizou-se uma contençăo dos resíduos orgânicos líquidos, de forma que somente a matéria orgânica solúvel fosse tratada. Entre os vários compostos presentes, escolheram-se os compostos do grupo BTEX, por serem mais persistentes no sistema de tratamento. Para isso, avaliaram-se os niveis residuais dos compostos do grupo BTEX durante um ano, abrangendo-se todas as fases do tratamento de efluentes. Apresentam-se a seguir as tabelas contendo os resultados encontrados. 
Tabela 17 - Comparação dos resultados de 12 meses do verão de 2002 ao verão de 2003 do reservatório antes do tratamento físico químico. Estes resultados são médias, expressas em $\mu \mathrm{g} / \mathrm{L}$.

\begin{tabular}{|c|c|c|c|c|c|}
\hline Compostos & $\begin{array}{c}\text { Verão } \\
2002 \\
\end{array}$ & $\begin{array}{c}\text { Outono } \\
2003\end{array}$ & $\begin{array}{c}\text { Inverno } \\
2003 \\
\end{array}$ & $\begin{array}{c}\text { Primavera } \\
2003 \\
\end{array}$ & $\begin{array}{c}\text { Verão } \\
2003 \\
\end{array}$ \\
\hline $\begin{array}{l}\text { Benzeno } \\
\text { Tolueno } \\
\text { Etil benzeno } \\
\text { p-Xileno } \\
\text { m-Xileno } \\
\text { o-Xileno }\end{array}$ & $\begin{array}{c}<L O D \\
336 \\
1514 \\
639 \\
1567 \\
577 \\
n=3\end{array}$ & $\begin{array}{c}<L Q O \\
17 \\
268 \\
183 \\
409 \\
59 \\
n=7\end{array}$ & $\begin{array}{c}<L O D \\
150 \\
1084 \\
722 \\
1679 \\
320 \\
n=7\end{array}$ & $\begin{array}{c}<L O D \\
3486 \\
2692 \\
1815 \\
4041 \\
998 \\
n=6\end{array}$ & $\begin{array}{c}<\text { LQO } \\
656 \\
483 \\
268 \\
628 \\
147 \\
n=8\end{array}$ \\
\hline
\end{tabular}

$\mathrm{Na}$ tabela 17, observa-se a concentração do grupo BTEX presente na água residual antes do tratamento físico-químico. Nessa fase, praticamente se utiliza um único tanque para retenção de todos os resíduos aquosos oriundos dos processos de limpeza dos equipamentos contaminados com produtos como solventes, tintas, vernizes, etc., com uma solução alcalina à base de $30 \%$ de hidróxido de sódio, de resíduos líquidos dos laboratórios e de água residual proveniente do processo de fabricação de polimeros. Observa-se nessa etapa uma grande quantidade de resíduos de todos os compostos do grupo BTEX.

$\mathrm{Na}$ tabela 18, observa-se uma pequena diminuição da concentração de todos os compostos estudados após o tratamento físicoquímico, em comparação com os dados sem o tratamento (Tabela 17). Essa diminuição pode estar relacionada à agitação do sistema para homogeneizar a água com os reagentes químicos, com a conseqüente perda do grupo BTEX por volatilização. É também possivel prever a adsorção do grupo BTEX dentro dos flocos formados com 0 intuito de remover partículas coloidais e sólidos em suspensão. 
Os compostos do grupo BTEX, nessa fase, podem sofrer degradação fotoquímica, em virtude da exposição à luz, sendo o mais sensivel a esse processo o etil benzeno. $O$ efeito de biodegradação provocada por microorganismos é insignificante nesse estágio.

Tabela 18 - Comparação dos resultados de 12 meses do verão de 2002 ao verão de 2003 após o tratamento físico químico. Estes resultados são médias, expressas em $\mu \mathrm{g} / \mathrm{L}$.

\begin{tabular}{|c|c|c|c|c|c|}
\hline COMPOSTOS & $\begin{array}{c}\text { Verão } \\
2002 \\
\end{array}$ & $\begin{array}{c}\begin{array}{c}\text { Outono } \\
2003\end{array} \\
\end{array}$ & $\begin{array}{c}\text { Inverno } \\
2003 \\
\end{array}$ & $\begin{array}{c}\text { Primavera } \\
2003 \\
\end{array}$ & $\begin{array}{c}\text { Verão } \\
2003\end{array}$ \\
\hline $\begin{array}{l}\text { Benzeno } \\
\text { Tolueno } \\
\text { Etil benzeno } \\
\text { p-Xileno } \\
\text { m-Xileno } \\
\text { o-Xileno }\end{array}$ & $\begin{array}{c}<\text { LOD } \\
262 \\
1416 \\
561 \\
1601 \\
536 \\
n=3\end{array}$ & $\begin{array}{c}<L O Q \\
18 \\
252 \\
170 \\
382 \\
57 \\
n=7\end{array}$ & $\begin{array}{c}<\text { LOD } \\
138 \\
1072 \\
721 \\
1629 \\
308 \\
n=7\end{array}$ & $\begin{array}{c}<\text { LOD } \\
2083 \\
1627 \\
1106 \\
2449 \\
571 \\
n=6\end{array}$ & $\begin{array}{c}<\text { LOQ } \\
466 \\
337 \\
197 \\
522 \\
111 \\
n=8\end{array}$ \\
\hline
\end{tabular}

Limite de quantificaçăo (LOQ) $=5 \mu \mathrm{g} / \mathrm{L}$. - Limite de detecçăo $(\mathrm{LOD})=1 \mu \mathrm{g} / \mathrm{L}$.

Tabela 19 - Comparação dos resultados de 12 meses do verão de 2002 ao verão de 2003 do tanque de equalização (tratamento biológico). Estes resultados são médias, expressas em $\mu \mathrm{g} / \mathrm{L}$.

\begin{tabular}{|c|c|c|c|c|c|}
\hline COMPOSTOS & $\begin{array}{c}\text { Verão } \\
2002\end{array}$ & $\begin{array}{c}\text { Outono } \\
2003\end{array}$ & $\begin{array}{c}\text { Inverno } \\
2003\end{array}$ & $\begin{array}{c}\text { Primavera } \\
2003\end{array}$ & $\begin{array}{c}\text { Verăo } \\
2003 \\
\end{array}$ \\
\hline $\begin{array}{l}\text { Benzeno } \\
\text { Tolueno } \\
\text { Etil benzeno } \\
\text { p-Xileno } \\
\text { m-Xileno } \\
\text { o-Xileno }\end{array}$ & $\begin{array}{c}<\text { LOD } \\
<\text { LOQ } \\
<\text { LOQ } \\
<\text { LOQ } \\
<\text { LOQ } \\
<L O Q \\
n=3\end{array}$ & $\begin{array}{c}<\text { LOD } \\
5 \\
9 \\
6 \\
16 \\
<L O Q \\
n=7\end{array}$ & $\begin{array}{c}<\text { LOD } \\
5 \\
26 \\
20 \\
41 \\
9 \\
n=7\end{array}$ & $\begin{array}{c}<L O Q \\
108 \\
106 \\
76 \\
172 \\
43 \\
n=6\end{array}$ & $\begin{array}{c}<L O Q \\
201 \\
14 \\
87 \\
189 \\
559 \\
n=8\end{array}$ \\
\hline
\end{tabular}

Limite de quantificaçăo (LOQ) $=5 \mu \mathrm{g} / \mathrm{L}$. - Limite de detecçăo (LOD) $=1 \mu \mathrm{g} / \mathrm{L}$. 
Observa-se nessa etapa (Tabela 19) uma significativa redução dos resíduos, independentemente da época do ano. As análises realizadas no verão de 2002 apresentaram resultados, para todos os componentes do grupo BTEX, abaixo do limite de quantificação $(5 \mu \mathrm{g} / \mathrm{L})$, o que indica uma excelente remoção dos poluentes e uma diferença perante os resultados das amostras do verão de 2003, que apresentou temperaturas médias inferiores às do ano anterior. As amostras analisadas no outono, no inverno e na primavera de 2003 apresentaram valores superiores aos observados no verão de 2002 e inferiores ao verão de 2003. Observa-se que mudanças na temperatura ambiente afetam diretamente 0 resultado no tanque de equalização. Uma gama ampla de microorganismos, liderados por bactérias, tem a função de biotransformar a matéria orgânica em moléculas menores até serem eliminadas como $\mathrm{CO}_{2}$ e água. Em vários trabalhos, menciona-se a ação de bactérias, tais como: Pseudomonas Putidas cepa 33, Pseudomonas stutzeri cepa 34, Micrococos cepa 41 e 43, Pseudomonas malthophilia cepa 18 (GULENSOY e ALVAREZ, 1999); entretanto, alguns fungos, como a Cladophialophora sp. cepa T1, demonstraram ser eficientes na biodegradação de hidrocarbonetos aromáticos. Em outros estudos, o tolueno foi assimilado pela Cladophialophora sp. cepa T1, por meio da oxidação do grupo metila ligado ao anel para álcool benzílico, posteriormente para ácido benzóico e, finalmente, a clivagem do anel (PRENAFETA-BOLDÚ et al., 2001).

O benzeno possui em sua estrutura química somente um anel aromático, sendo necessária, portanto, a presença de fungos que tenham a capacidade de iniciar a oxidação por meio do anel aromático. Em geral, a cepa T1 tem a capacidade de oxidar a cadeia de alquil benzenos (tolueno, etil benzeno $e$ xilenos), por intermédio da enzima monooxigenase (PRENAFETA-BOLDÚ et al., 2002).

KOBAYASHI e RITTIMANN (2000) citam em seu trabalho alguns fungos que podem metabolizar poluentes ambientais, tais como: 
Aureobasidium pullutans (cresol), Cunninghamella elegans (policiclos aromáticos, benzo(a)pirenos), naftaleno), Trichoderma viridae (pentacloro nitro benzeno), entre outros.

Mesmo sendo a fase mais importante para degradação da matéria orgânica e dos compostos do grupo BTEX, o tratamento por lodo ativado no tanque de equalização não foi suficiente para eliminar os residuos dos compostos do grupo BTEX em todas as estações do ano, necessitando ser complementado nas outras fases.

Tabela 20 - Comparação dos resultados de 12 meses do verão de 2002 ao verão de 2003 da lagoa de estabilização 1 (tratamento biológico). Estes resultados são médias, expressas em $\mu \mathrm{g} / \mathrm{L}$.

\begin{tabular}{lccccc}
\hline compostos & $\begin{array}{c}\text { Verão } \\
2002\end{array}$ & $\begin{array}{c}\text { Outono } \\
2003\end{array}$ & $\begin{array}{c}\text { Inverno } \\
2003\end{array}$ & $\begin{array}{c}\text { Primavera } \\
2003\end{array}$ & $\begin{array}{c}\text { Verão } \\
2003\end{array}$ \\
\hline Benzeno & $<L O D$ & $<L O D$ & $<L O D$ & $<L O D$ & $<L O D$ \\
Tolueno & $<L O Q$ & 9 & 70 & $<L O Q$ & $<L O Q$ \\
Etil benzeno & 9 & 6 & 23 & $<L O Q$ & $<L O Q$ \\
p-Xileno & 9 & 5 & 26 & $<L O Q$ & $<L O Q$ \\
m-Xileno & 15 & 9 & 45 & $<L O Q$ & $<L O Q$ \\
o-Xileno & $<L O Q$ & $<L O Q$ & 6 & $N D$ & $<L O Q$ \\
& $n=3$ & $n=7$ & $n=7$ & $n=6$ & $n=8$ \\
\hline
\end{tabular}

Limite de quantificaçăo $(L O Q)=5 \mu \mathrm{g} / \mathrm{L}$. - Limite de deteç̧ăo $(\mathrm{LOD})=1 \mu \mathrm{g} / \mathrm{L}$.

$\mathrm{Na}$ tabela 20, observa-se que os resíduos continuam a ser reduzidos, em comparação com resíduos analisados no tanque de equalizaçăo, o que demonstra que o biolodo presente nessa etapa continua contribuindo para a biodegradação dos compostos químicos em estudo. Nessa fase, observa-se que os resultados referentes ao grupo BTEX da primavera e do verăo de 2003 estão abaixo dos valores referentes às estaçס̃es do verão de 2002, outono e inverno de 2003. 
Tabela 21 - Comparação dos resultados de 12 meses do verão de 2002 ao verão de 2003 da lagoa de estabilização 2 (tratamento biológlco). Estes resultados são médias, expressas em $\mu \mathrm{g} / \mathrm{L}$.

\begin{tabular}{lccccc}
\hline \multicolumn{1}{c}{ COMPOSTOS } & $\begin{array}{c}\text { Verão } \\
2002\end{array}$ & $\begin{array}{c}\text { Outono } \\
2003\end{array}$ & $\begin{array}{c}\text { Inverno } \\
2003\end{array}$ & $\begin{array}{c}\text { Primavera } \\
2003\end{array}$ & $\begin{array}{c}\text { Verão } \\
2003\end{array}$ \\
\hline Benzeno & $<$ LOD & $<$ LOD & $<$ LOD & $<$ LOD & $<$ LOD \\
Tolueno & 5 & 10 & 68 & $<L O Q$ & $<L O Q$ \\
Etil benzeno & $<L O Q$ & 7 & 17 & $<L O Q$ & $<L O Q$ \\
p-Xileno & $<L O Q$ & 5 & 17 & $<L O Q$ & $<L O Q$ \\
m-Xileno & $<L O Q$ & 11 & 30 & $<L O Q$ & $<L O Q$ \\
o-Xileno & $<L O Q$ & $<L O Q$ & $<L O Q$ & $<L O Q$ & $<L O Q$ \\
& $n=3$ & $n=7$ & $n=7$ & $n=6$ & $n=8$ \\
\hline
\end{tabular}

Limite de quantificaçăo (LOQ) $=5 \mu \mathrm{g} / \mathrm{L}$. - Limite de deteç̧ăo (LOD) $=1 \mu \mathrm{g} / \mathrm{L}$.

$\mathrm{Na}$ tabela 21, observa-se uma diminuição dos resíduos, principalmente no outono e inverno de 2003. Para o verão de 2002, somente se identificou e quantificou o tolueno, na ordem de $5 \mu \mathrm{g} / \mathrm{L}$; entretanto, para as amostras do outono de 2003, somente o o-xileno estava abaixo do limite de quantificação, e o etil benzeno, o p-xileno e o $\mathrm{m}$-xileno, entre 5 e $11 \mu \mathrm{g} / \mathrm{L}$. Nas amostras analisadas no inverno de 2003 , observam-se também teores entre 17 e $30 \mu \mathrm{g} / \mathrm{L}$ de tolueno, etil benzeno e $m$-xileno. Essa fase do processo demonstra também boa biodegradação dos componentes do grupo BTEX.

Tabela 22 - Comparação dos resultados de 12 meses do verão de 2002 ao verão de 2003 da lagoa de estabilização 3 (tratamento biológico). Estes resultados são médias, expressas em $\mu \mathrm{g} / \mathrm{L}$.

\begin{tabular}{lccccc}
\hline \multicolumn{1}{c}{ COMPOSTOS } & $\begin{array}{c}\text { Verão } \\
2002\end{array}$ & $\begin{array}{c}\text { Outono } \\
2003\end{array}$ & $\begin{array}{c}\text { Inverno } \\
2003\end{array}$ & $\begin{array}{c}\text { Primavera } \\
2003\end{array}$ & $\begin{array}{c}\text { Verão } \\
2003\end{array}$ \\
\hline Benzeno & $<L O D$ & $<L O D$ & $<L O D$ & $<$ LOD & $<$ LOD \\
Tolueno & $<L O Q$ & $<L O Q$ & 51 & $<L Q O$ & $<L O Q$ \\
Etil benzeno & $<L O Q$ & $<L O Q$ & 12 & $<L Q O$ & $<L O Q$ \\
p-Xileno & $<L O Q$ & $<L O Q$ & 13 & $<L Q O$ & $<L O Q$ \\
m-Xileno & $<L O Q$ & 6 & 21 & $<L Q O$ & $<L O Q$ \\
o-Xileno & $<L O Q$ & $<L O Q$ & $<L O Q$ & $<L Q O$ & $<L O Q$ \\
& $n=3$ & $n=7$ & $n=7$ & $n=6$ & $n=8$ \\
\hline
\end{tabular}

Limite de quantificaçăo (LOQ) $=5 \mu \mathrm{g} / \mathrm{L}$. - Limite de deteç̧ăo (LOD) $=1 \mu \mathrm{g} / \mathrm{L}$. 
$\mathrm{Na}$ última lagoa de estabilização (Tabela 22), observa-se o resultado final do processo de tratamento dos efluentes. No verão de 2002, na primavera e no verão de 2003, praticamente em todas as amostras analisadas não foi encontrada a presença de benzeno, ao passo que os outros compostos (tolueno, etil benzeno, p-xileno, $m$-xileno e o-xileno) apresentaram concentrações inferiores ao limite de quantificação do método $(5 \mu \mathrm{g} / \mathrm{L})$.

Especificamente para o inverno de 2003, observa-se uma resistência maior à biodegradação do tolueno, etil benzeno, p-xileno e $\mathrm{m}$ xileno $(51,12,13$ e $21 \mu \mathrm{g} / \mathrm{L}$, respectivamente); para o o-xileno, as concentraçōes observadas estavam abaixo do limite de quantificação do método.

\subsubsection{Avaliação da biodegradabilidade dos compostos do grupo BTEX durante o ciclo completo de tratamento de efluentes}

Avaliaram-se os niveis residuais dos compostos do grupo BTEX em cinco ciclos completos de tratamento de efluentes: verão de 2002 , verão de 2003, outono de 2003, inverno de 2003 e primavera de 2003. Apresentam-se a seguir as tabelas contendo os resultados encontrados. 
Tabela 23 - Avaliação da biodegradabilidade do grupo BTEX após o tratamento de efluentes durante o verăo de 2002. Os resultados apresentados são médias de três determinações, expressas em $\mu \mathrm{g} / \mathrm{L}$.

\begin{tabular}{c|c|c|c|c|c|c}
\hline Fases do tratamento & Benzeno & Tolueno & Etil Benzeno & p-Xileno & m-Xileno & o-Xileno \\
\hline $\begin{array}{c}\text { Antes do tratamento } \\
\text { físico-químico }\end{array}$ & $<$ LOD & 366 & 1514 & 639 & 1567 & 577 \\
$\begin{array}{c}\text { Após o tratamento } \\
\text { fisico-quimico }\end{array}$ & $<L O D$ & 262 & 1416 & 561 & 1601 & 536 \\
$\begin{array}{c}\text { Tanque de } \\
\text { equalização } \\
\begin{array}{c}\text { Lagoa de } \\
\text { estabilização 1 }\end{array}\end{array}$ & $<$ LOD & $<L O Q$ & $<L O Q$ & $<L O Q$ & $<L O Q$ & $<L O Q$ \\
$\begin{array}{c}\text { Lagoa de } \\
\text { estabilização 2 }\end{array}$ & $<L O D$ & 5 & $<L O Q$ & $<L O Q$ & $<L O Q$ & $<L O Q$ \\
$\begin{array}{c}\text { Lagoa de } \\
\text { estabilização 3 }\end{array}$ & $<L O D$ & $<L O Q$ & $<L O Q$ & $<L O Q$ & $<L O Q$ & $<L O Q$ \\
\hline
\end{tabular}

Limite de quantificaçăo (LOQ) $=5 \mu \mathrm{g} / \mathrm{L}$. - Limite de deteç̧ăo $(\mathrm{LOD})=1 \mu \mathrm{g} / \mathrm{L}$. 
Tabela 24 - Avaliação da biodegradabilidade do grupo BTEX após o tratamento de efluentes durante o verão de 2003. Os resultados apresentados são médias de oito determinações, expressas em $\mu \mathrm{g} / \mathrm{L}$.

\begin{tabular}{|c|c|c|c|c|c|c|}
\hline Fases do tratamento & Benzeno & Tolueno & Etil Benzeno & p-Xileno & m-Xileno & 0-Xileno \\
\hline $\begin{array}{l}\text { Antes do tratamento } \\
\text { físico-químico }\end{array}$ & $<\mathrm{LOQ}$ & 656 & 483 & 268 & 628 & 147 \\
\hline $\begin{array}{l}\text { Após o tratamento } \\
\text { físico-químico }\end{array}$ & $<\mathrm{LOQ}$ & 466 & 337 & 196 & 522 & 111 \\
\hline $\begin{array}{l}\text { Tanque de } \\
\text { equalização }\end{array}$ & $<L O Q$ & 201 & 14 & 87 & 189 & 56 \\
\hline $\begin{array}{c}\text { Lagoa de } \\
\text { estabilização } 1\end{array}$ & $<L O D$ & $<L O Q$ & $<\mathrm{LOQ}$ & $<L O Q$ & $<\mathrm{LOQ}$ & $<\mathrm{LOQ}$ \\
\hline $\begin{array}{c}\text { Lagoa de } \\
\text { estabilização } 2\end{array}$ & $<$ LOD & $<L O Q$ & $<L O Q$ & $<\mathrm{LOQ}$ & $<\mathrm{LOQ}$ & $<L O Q$ \\
\hline $\begin{array}{c}\text { Lagoa de } \\
\text { estabilização } 3\end{array}$ & $<L O D$ & $<L O Q$ & $<\mathrm{LOQ}$ & $<\mathrm{LOQ}$ & $<\mathrm{LOQ}$ & $<\mathrm{LOQ}$ \\
\hline
\end{tabular}

Limite de quantificaçăo $(L O Q)=5 \mu g / L$. - Limite de detecçăo $(L O D)=1 \mu g / L$. 
Tabela 25 - Avaliação da biodegradabilidade do grupo BTEX após o tratamento de efluentes durante o outono de 2003. Os resultados apresentados são médias de sete determinações, expressas em $\mu \mathrm{g} / \mathrm{L}$.

\begin{tabular}{|c|c|c|c|c|c|c|}
\hline Fases do tratamento & Benzeno & Tolueno & Etil Benzeno & p-Xileno & m-Xileno & o-Xileno \\
\hline $\begin{array}{l}\text { Antes do tratamento } \\
\text { físico-químico }\end{array}$ & $<L O Q$ & 17 & 268 & 183 & 409 & 59 \\
\hline $\begin{array}{l}\text { Após o tratamento } \\
\text { físico-químico }\end{array}$ & $<L O Q$ & 18 & 252 & 170 & 382 & 57 \\
\hline $\begin{array}{l}\text { Tanque de } \\
\text { equalização }\end{array}$ & $<L O D$ & 5 & 9 & 6 & 16 & $<L O Q$ \\
\hline $\begin{array}{c}\text { Lagoa de } \\
\text { estabilização } 1\end{array}$ & $<L O D$ & 9 & 6 & 5 & 9 & $<L O Q$ \\
\hline $\begin{array}{c}\text { Lagoa de } \\
\text { estabilização } 2\end{array}$ & $<L O D$ & 10 & 7 & 5 & 11 & $<L O Q$ \\
\hline $\begin{array}{c}\text { Lagoa de } \\
\text { estabilização } 3\end{array}$ & $<L O D$ & $<L O Q$ & $<L O Q$ & $<\mathrm{LOQ}$ & 6 & $<L O Q$ \\
\hline
\end{tabular}

Limite de quantificaçăo $(L O Q)=5 \mu \mathrm{g} / \mathrm{L}$. - Limite de deteçăa $(\mathrm{LOD})=1 \mu \mathrm{g} / \mathrm{L}$. 
Tabela 26 - Avaliação da biodegradabilidado do grupo BTEX após o tratamento de efluentes durante 0 inverno de 2003. Os resultados apresentados são médias de sete determinações, expressas em $\mu \mathrm{g} / \mathrm{L}$.

\begin{tabular}{|c|c|c|c|c|c|c|}
\hline Fases do tratamento & Benzeno & Tolueno & Etil Benzeno & p-Xileno & m-XIleno & o-Xileno \\
\hline $\begin{array}{l}\text { Antes do tratamento } \\
\text { físico-quimico }\end{array}$ & $<L O D$ & 150 & 1084 & 722 & 1679 & 320 \\
\hline $\begin{array}{l}\text { Após o tratamento } \\
\text { fisico-químico }\end{array}$ & $<L O D$ & 138 & 1072 & 721 & 1629 & 308 \\
\hline $\begin{array}{l}\text { Tanque de } \\
\text { equalização }\end{array}$ & $\angle L O D$ & 5 & 26 & 20 & 41 & 9 \\
\hline $\begin{array}{c}\text { Lagoa de } \\
\text { estabilização } 1\end{array}$ & $\angle L O D$ & 70 & 23 & 26 & 45 & 6 \\
\hline $\begin{array}{c}\text { Lagoa de } \\
\text { estabilização } 2\end{array}$ & $<L O D$ & 68 & 17 & 17 & 30 & $<L O Q$ \\
\hline $\begin{array}{c}\text { Lagoa de } \\
\text { estabilizaçăo } 3\end{array}$ & $<L O D$ & 51 & 12 & 13 & 21 & $<\mathrm{LOQ}$ \\
\hline
\end{tabular}

Limite de quantificaçăo $(L O Q)=5 \mu g / L$. - Limite de deteç̧ăo $(L O D)=1 \mu g / L$. 
Tabela 27 - Avaliação da biodegradabilidade do grupo BTEX após o tratamento de efluentes durante a primavera de 2003. Os resultados apresentados são médias de seis determinações, expressas em $\mu \mathrm{g} / \mathrm{L}$.

\begin{tabular}{|c|c|c|c|c|c|c|}
\hline Fases do tratamento & Benzeno & Tolueno & Etil Benzeno & p-Xileno & m-Xileno & o-Xileno \\
\hline $\begin{array}{l}\text { Antes do tratamento } \\
\text { físico-químico }\end{array}$ & $<L O D$ & 3486 & 2692 & 1815 & 4141 & 998 \\
\hline $\begin{array}{l}\text { Após o tratamento } \\
\text { físico-químico }\end{array}$ & $<L O D$ & 2083 & 1627 & 1106 & 2449 & 571 \\
\hline $\begin{array}{l}\text { Tanque de } \\
\text { equalização }\end{array}$ & $<L O D$ & 108 & 106 & 76 & 172 & 43 \\
\hline $\begin{array}{c}\text { Lagoa de } \\
\text { estabilizaçăo } 1\end{array}$ & $<L O D$ & $<L O Q$ & $<L O Q$ & $<\mathrm{LOQ}$ & $<L O Q$ & ND \\
\hline $\begin{array}{c}\text { Lagoa de } \\
\text { estabilizaçăo } 2\end{array}$ & $<L O D$ & $<L O Q$ & $<L O Q$ & $<L O Q$ & $<L O Q$ & $<L O Q$ \\
\hline $\begin{array}{c}\text { Lagoa de } \\
\text { estabilização } 3\end{array}$ & $<L O D$ & $<L O Q$ & $<L O Q$ & $<L O Q$ & $<L O Q$ & $<\mathrm{LOQ}$ \\
\hline
\end{tabular}

Limite de quantificaçăo (LOQ) $=5 \mu \mathrm{g} / \mathrm{L}$. - Limite de deteç̧ăo (LOD) $=1 \mu \mathrm{g} / \mathrm{L}$. 
Podem-se observar, nas tabelas de 23 a 27, os niveis residuais dos compostos do grupo BTEX em cinco ciclos completos de tratamento de efluentes. Em todas as fases do tratamento, independentemente do ciclo avaliado, não foram encontrados residuos de benzeno acima do limite de quantificação do método. Avaliando-se a eficiência entre as fases do tratamento, observa-se que houve uma redução significativa dos residuos encontrados após o tratamento no tanque de equalização. $\mathrm{Na}$ etapa seguinte do tratamento - lagoa de estabilização 1-, o biolodo presente favorece ainda mais a degradação dos compostos, pois se verifica a redução dos resíduos. Nas lagoas de estabilização 2 e 3, o processo de degradação é mais lento, porém essas etapas são importantes principalmente nas épocas mais frias do ano.

O tratamento de efluentes mostrou-se mais eficiente nas épocas mais quentes do ano (verão e primavera), principalmente após a etapa do tanque de equalização. Nenhum resíduo dos compostos do grupo BTEX foi encontrado acima do limite de quantificação do método nessa épocas do ano. Nos períodos mais frios (outono e inverno), observou-se uma maior incidência de resíduos; isso se deve, provavelmente, pela diminuição do metabolismo bacteriano, o que interfere na quantidade de BTEX metabolizado, aumentando-se, dessa forma, a concentração dessas substâncias na água. RULA e ALVARES (1999) observaram que a temperatura de $35^{\circ} \mathrm{C}$ é ideal para se obter uma excelente biodegradação de tolueno, etil benzeno e isômeros de xileno.

No outono, encontrou-se $m$-xileno, e os resíduos dos demais compostos do grupo BTEX encontravam-se abaixo do limite de quantificação do método. Concluídas todas as etapas de tratamento dos efluentes no periodo do inverno, ainda se encontraram tolueno, etil benzeno, p-xileno e $m$-xileno na lagoa de estabilização 3 , última etapa do tratamento de efluentes. 
Comparando-se os resultados obtidos neste estudo da água de lançamento para o corpo receptor, observou-se que os teores de benzeno estão abaixo do mencionado no estudo do EPA (1979): $10 \mu \mathrm{g} / \mathrm{L} \mathrm{em}$ indústrias de tintas dos Estados Unidos e $111 \mu \mathrm{g} / \mathrm{L}$ (DAMATO, 1997) em refinarias de petróleo. Para o tolueno, encontramos concentrações abaixo do limite de quantificação do método e o EPA (1979) não detectou a presença desse composto; DAMATO (1997) encontrou $582 \mu \mathrm{g} / \mathrm{L}$ em refinaria de petróleo. Para o etil benzeno, encontramos concentrações abaixo do limite de quantificação do método e o CMAEPA (1982) encontrou $5 \mu \mathrm{g} / \mathrm{L}$. Para os isômeros de xileno, somente em uma amostra observou-se a presença de 6 $\mu \mathrm{g} / \mathrm{L}$ no outono; o EPA (1979) não detectou a presença desses compostos e DAMATO (1997) encontrou $1.130 \mu \mathrm{g} / \mathrm{L}$ no efluente da refinaria de petróleo.

Podemos ainda prever que, nos meses com temperaturas mais baixas (inverno), o grupo BTEX poderá não ser metabolizado adequadamente e ser eliminado em maiores quantidades no ambiente do que nas estações mais quentes do ano. Entretanto, comparadas as concentrações de BTEX de refinarias de petróleo com os valores encontrados no presente estudo, podemos prever que elas serão inferiores se o sistema permanecer estável nas mesmas condições do estudo. Comparando-se os resultados deste estudo com o dado do EPA, podemos afirmar que o sistema de tratamento tem excelente resultado.

\subsubsection{Avaliação do risco à saúde do homem}

Considerando-se que não estão estabelecidos, na resolução n. 20 do CONAMA (18/06/1986), na lei estadual 997/SP (31/05/1976) e no decreto estadual $8.468 / \mathrm{SP}$ (08/09/1976), parâmetros para lançamento de águas residuárias contendo o grupo BTEX, comparamos os resultados obtidos após o tratamento de efluentes com os padrōes de potabilidade aceitos para água de consumo humano. Também observamos que somente 
o benzeno foi citado na resolução do Conama, para classificação de águas doces, salobras e salinas.

Conforme estabelece a portaria n. 1.469 (29/12/2000), publicada pelo Ministério da Saúde, são permitidos os seguintes níveis residuais em água potável para consumo humano:

Tabela 28 -.Límites máximos permitidos para água de consumo humano

\begin{tabular}{cc}
\hline Compostos & $\begin{array}{c}\text { Limite máximo } \\
\text { Aceitável }(\mu \mathrm{g} / \mathrm{L})\end{array}$ \\
\hline Benzeno & 5 \\
Tolueno & 170 \\
Etil benzeno & 200 \\
p-Xileno & 300 \\
m-XIleno & 300 \\
o-Xileno & 300 \\
\hline
\end{tabular}

Fonte: Port. 1469 (29/12/2000) 
Tabela 29 - Comparação dos resultados de resíduo do grupo BTEX após tratamento físico-químico e biológico com os limites máximos permitidos em água potável. Estes resultados são médias, expressas em $\mu \mathrm{g} / \mathrm{L}$.

\begin{tabular}{l|c|c|c|c|c|c}
\hline Substâncias & $\begin{array}{c}\text { Verão } \\
2002\end{array}$ & $\begin{array}{c}\text { Outono } \\
2003\end{array}$ & $\begin{array}{c}\text { Inverno } \\
2003\end{array}$ & $\begin{array}{c}\text { Primavera } \\
2003\end{array}$ & $\begin{array}{c}\text { Verão } \\
2003\end{array}$ & $\begin{array}{c}\text { Limites } \\
\text { Máximos } \\
\text { Permitidos }\end{array}$ \\
\hline Benzeno & $<L O D$ & $<L O D$ & $<L O D$ & $<L O D$ & $<L O D$ & 5 \\
Tolueno & $<L O Q$ & $<L O Q$ & 51 & $<L Q O$ & $<L O Q$ & 170 \\
Etil benzeno & $<L O Q$ & $<L O Q$ & 12 & $<L Q O$ & $<L O Q$ & 200 \\
p-Xileno & $<L O Q$ & $<L O Q$ & 13 & $<L Q O$ & $<L O Q$ & 300 \\
m-Xileno & $<L O Q$ & 6 & 21 & $<L Q O$ & $<L O Q$ & 300 \\
o-Xileno & $<L O Q$ & $<L O Q$ & $<L O Q$ & $<L Q O$ & $<L O Q$ & 300 \\
\hline
\end{tabular}

Limite de quantificaçăo (LOQ) $=5 \mu \mathrm{g} / \mathrm{L}$. - Limite de deteç̧ăo (LOD) $=1 \mu \mathrm{g} / \mathrm{L}$.

(") Limites máximos permitidos em água potável. Port. 1469 (29/12/00) - Ministério da Saúde

O tratamento de efluentes exposto neste estudo apresenta residuos dos compostos do grupo BTEX abaixo dos limites máximos aceitáveis para água potável, conforme demonstrado nas tabelas 28 e 29.

Portanto, a água eliminada para o corpo receptor, mesmo não sendo utilizada diretamente para o consumo humano, apresenta niveis residuais de BTEX aceitáveis, não oferecendo risco à saúde humana. Após o lançamento da água tratada no corpo receptor, podemos prever que os baixos niveis de BTEX ainda sofrem a biodegradação natural pelos microorganismos presentes no solo, na água dos córregos, rios e lagos; dessa forma, diminuirá ainda mais sua concentração no ambiente. 


\section{CONCLUSÕES}

O estudo realizado com o grupo BTEX, por meio da otimização do método analítico e da avaliação do sistema de tratamento de efluentes industriais, permite as seguintes conclusões:

- Os interferentes ambientais são importantes por dificultarem a aplicação da técnica, sendo necessário trabalhar em uma sala sem contaminantes. Quando isso não é possivel, é necessário proteger a fibra SPME de possiveis contaminações cruzadas, mantendo-se a fibra em ambiente inerte e em constante dessorção no injetor;

\section{- Contaminações devidas à adsorção do BTEX pelos} materiais eram fontes de erro e de aumento do efeito memória da fibra. Esses efeitos foram minimizados por meio de cuidados simples, como secar o material de vidro, o septo e cloreto de sódio na estufa a $230^{\circ} \mathrm{C}$ durante três horas; entretanto, a água para diluição utilizada na preparação dos padrões teve de ser obtida em um poço semi-artesiano e, posteriormente, desgaseificada por agitação na presença de um fluxo constante de gás hélio. A água purificada em sistema Milli $Q$ convencional não pôde ser utilizada, por não remover contaminações de substâncias orgânicas abaixo de 20 $\mathrm{mg} / \mathrm{L}$;

- O método analítico otimizado neste trabalho com detector DIC (detector de ionização de chama) mostrou ter uma relação custo/benefício mais aceitável do que métodos que utilizam. a espectrometria de massas, em decorrência do alto custo dessa técnica analítica. $O$ método aqui proposto atende aos niveis de resíduo que devem ser determinados de acordo com a legislação brasileira, que impõe $5 \mu \mathrm{g} / \mathrm{L}$ como limite máximo permitido para benzeno como padrão de potabilidade de água de consumo; 
- Os parâmetros de validação estudados para o método otimizado apresentaram excelente seletividade, linearidade, limites de detecção (LOD) e quantificação (LOQ), exatidão e precisão para as determinações dos compostos do grupo BTEX. O método apresentou excelente seletividade, os coeficientes de correlação obtidos nas curvas de calibração estiveram entre 0,9992 e 0,9996. O limite de detecção (LOD) encontrado foi de $1 \mu \mathrm{g} / \mathrm{L}$ para todas as substâncias;

- Baseando-se no estudo de recuperação em que se realizaram fortificações dos compostos do grupo BTEX nos níveis de 5 e 80 $\mu \mathrm{g} / \mathrm{L}$, conclui-se que o método analítico é valido para a realizaçăo de análise de resíduo dos compostos do grupo BTEX em águas residuais de efluentes provenientes do tratamento físico-químico e biológico. $O$ limite de quantificação (LOQ) encontrado é de $5 \mu \mathrm{g} / \mathrm{L}$ para todos os compostos d BTEX. A exatidão do método foi determinada para todos os analitos do grupo BTEX, encontrando-se todos eles [OS ANALITOS?] dentro dos limites aceitáveis (70-120\%). Conclui-se que o método é preciso, pois a repetibilidade dos resultados de recuperação para todos os compostos do grupo BTEX, no nível de $5 \mu \mathrm{g} / \mathrm{L}$, apresentou o coeficiente de variação entre 10 e $14 \%$ e, para o nível de $80 \mu \mathrm{g} / \mathrm{L}$, entre 6 e $9 \%$, sendo o limite máximo aceitável $\leq 20 \%$. A incerteza de medição foi determinada por meio do intervalo de confiança (desvio-padrão) da média das recuperações. Para todos os compostos do grupo BTEX, no nível de $5 \mu \mathrm{g} / \mathrm{L}$, o desvio-padrão apresentou-se entre 0,5 e $0,7 \%$ e, para o nivel de $80 \mu \mathrm{g} / \mathrm{L}$, entre 4,0 e $6,0 \%$;

- A extração dos compostos do grupo BTEX pela fibra SPME (Solid Phase Micro-Extraction) demonstrou eficiência e precisão após se avaliarem os resultados obtidos na validação do método;

- $\quad$ O sistema de extração SPME é simples e mais rápido do que algumas técnicas de extração e concentração convencionais e muito sensivel para baixas concentrações de BTEX, podendo ser utilizado para 
pequenas quantidades de amostra. Entretanto, a extração direta dos analitos por imersão não teve resultados confiáveis, em virtude da alta concentração de matéria orgânica na matriz;

- $\quad$ Este método foi desenvolvido segundo os preceitos do Green Chemistry, em que se utilizam pequenas quantidades de solventes capazes de ocasionar contaminação ambiental;

- Comparando-se o custo operacional da técnica de extração por SPME com outras técnicas, observou-se que ela tem custo operacional muito inferior às demais técnicas, proporcionando um custobeneficio mais vantajoso para pequenos laboratórios e indústrias;

- $\quad$ Em todas as fases do tratamento de efluentes, não se encontraram resíduos de benzeno acima do limite de quantificação do método. Avaliando-se a eficiência entre as fases do tratamento de efluente, observou-se que houve uma redução significativa dos resíduos após o tratamento no tanque de equalização. Na etapa da lagoa de estabilização 1 , o biolodo presente favoreceu ainda mais a degradação dos compostos, pois se verificou a redução dos residuos. Nas lagoas de estabilização 2 e 3, o processo de degradação foi mais lento, porém essas etapas são importantes principalmente nas épocas mais frias do ano;

- $\quad$ Conclui-se que o sistema de tratamento de efluentes apresenta uma maior eficiência nas épocas mais quentes do ano, pois no outono e inverno se observou que os resíduos não foram completamente degradados;

- A água eliminada para o corpo receptor após o tratamento dos efluentes, mesmo não sendo utilizada diretamente para o consumo humano, apresenta níveis residuais de BTEX aceitáveis, não oferecendo risco à saúde humana, quando comparados com os niveis 
máximos mencionados na portaria 1.469 do Ministério da Saúde. Devemos considerar ainda que os baixos níveis de BTEX eliminados podem ainda sofrer biodegradação ambiental, por meio de microorganismos presentes no solo e nos corpos de água, possibilitando a diminuição das concentrações desses compostos no ambiente. 


\section{RECOMENDAÇÕES}

- Desenvolver metodologia específica para a determinação de BTEX em solos, peixes, alimentos e águas subterrâneas;

- Ampliar a presente pesquisa para outros sistemas de tratamento de efluentes industriais e comparar entre eles a eficiência na remoção de substâncias tóxicas;

- Determinar quais são os principais microorganismos presentes no tratamento de efluentes industriais e sua efetiva participação na degradação do BTEX;

- Determinar a concentração de BTEX na gordura de peixes que estão sendo utilizados como indicadores em sistema de tratamento;

- A metodologia otimizada tem ampla aplicação na determinação de resíduos de compostos do grupo BTEX em água do tratamento de efluentes, podendo ainda ser aplicada para análise de águas subterrâneas, superficiais e potável. 
7.

1.

2.

3.

4.

5.

6.

7.

\section{BIBLIOGRAFIA}

ABIQUIM - Associação Brasileira das Industrias Químicas Produção de solventes aromáticos no ano de 2002. http://abiquim.gov.br/

ACS - The American Chemical Society Principles of Environmental Analysis - Committee on Environmental Improvement - 1983

Arthur, C, Killiam, L, Buchholz, K, Pawliszyn, J. - Automation and Optimization of Solid Phase Micro-Extration - Anal. Chem. 64: 1960-1966 (1992).

Arthur, C, Pawliszyn, J. - Dynamics of Organic Compound Extration from Water, using Liquid-Coated Fused Silica Fibers - Anal. Chem. 66: 1186-1199 (1994).

Arthur, C, Pawliszyn, J. - Solid Phase MicroExtration with Thermal Desorption Using Fused Silica Optical Fibers - Anal. Chem. 62: 2145-2148 (1990).

Arthur, CL., Potter, KD, Bucholz, Mothagh, S, Pawliszyn, J. Solid Phase Microextration for the Direct Analysis of Water: Theory and Practice - J. Liq. Chrom.-Gas Chrom ,10 (9), 656$661(1992)$

ASTM - (D 6520-00) - Standard Practise for the Solid Phase Micro Extration (SPME) of Water and its Headspace for Analysis of Volatile and Semi-Volatile Organics Compauds Annual Book of ASTM Standards, vol II.04. - 2000. 
8. ATSDR - Agency for Toxic Substances and Disease Registry Public Health Statement for Benzene Toxicological profile for benzene. Atlanta, GA: U.S. Department of health and human services, Public Health Service - September - 1997. http://www.atsde.cdc.gov/

9. ATSDR - Agency for Toxic Substances and Disease Registry Public Health Statement for Ethyl Benzene - Toxicological profile for Ethyl benzene. Atlanta, GA: U.S. Department of health and human services, Public Health Service - July 1999. http://www.atsde.cdc.gov/

10. ATSDR- Agency for Toxic Substances and Disease Registry (ATSDR) U.S. Public health service. ToxFAQs ${ }^{T M}$. Hazardous Substance Fact Sheets. Atlanta, GA: Clement International Corp. 2001. - http://atsdr.cdc.gov/

11. ATSDR- Agency for Toxic Substances and Disease Registry Public Health Statement for Toluene - Toxicological profile for toluene. Atlanta, GA: U.S. Department of health and human services, Public Health Service - May -1994. http://www.atsde.cdc.gov/

12. ATSDR- Agency for Toxic Substances and Disease Registry Public Health Statement for Xylene -Toxicological profile for Xylene. Atlanta, GA: U.S. Department of health and human services, Public Health Service - August - 1995. http://www.atsde.cdc.gov/

13. Belardi, R, Pawliszyn, J. - The Application of Chemically Modified Fused Silica Fibers in the Extraction of Organics from water matrix samples and their rapid transfer to capillary 
columns. Water pollution research J. Canada 24:179 - 1989

14. Bellar, TA; Lichtenberg, JJ - Determining volatile organics at microgram-per-liter levels by gas chromatography. Journal of American Water Works Association, v. 66, n.12, pag. 739, Dec. 1974.

15. Benzene data bank - Hazard Substance Databank (HSDB), data base of the National Library of Medicine's, TOXNET system. (http://toxnet.nIm.nih.gov) - June - 2002

16. Boyd-Boland, A, Chai, M, Luo, Y, Zhang, Z, Yang, M, Gorecki, T, Pawliszyn, J -Solvent Free Sample Preparation Techniques Based on Fiber and Polymer Technologies - Environ. Sci. Technol. 28:569A-574A (1994).

17. Brower, GR. et al. - Removal of Hazardous Wastes in Waster Facilities: Halogenated Organics (Manual of Practice, FD-11), Washington, Water Pollution Control Federation, 1986

18. Buchholz, K, Pawliszyn J. - Determination of Phenols by SPME and GC analysis. J. Environ. Sci. Technol. 27(13): 2844-2848 1993

19. Casarett and Doll's Toxicology. The basic science of poisons. 5th ed. New york, NY, McGraw Hill, 1995. 742

20. Casarini, DCP; Dias CL e Lemos MG - Aplicação de análise de risco para definição de parâmetros Ambientais de Referência. - Seminário de Avaliação de risco ambiental Bases para estratégias de remediação de áreas contaminadas $-1999$. 
21. Chai, M, Pawliszyn, J. - Analysis of Environmental Air Samples by Solid Phase microextration and GC/lon Trap Mass Spectrometry - Environ. Sci. Technol. 29: 693-701 (1995)

22. Chor K, Stockholm J. Toluene: a toxicology review. Scand J Work Environ Health 1979;5:71-90t

23. Clayton, GD, Clayton FD. (eds). Patty's Industrial Hygiene and Toxicology. Volumes 2A, 2B, 2C, 2D, 2F: Toxicology 4th ed. New York, NY. John Wiley \& Sons Inc. 1993-1994.1343 and 1318

24. Collins, $\mathrm{CH}$, Braga, $\mathrm{GL}$ - Introdução a métodos cromatográficos- Editora UNICAMP - 2a Edição - 1987

25. Courseil, $H X$ - Avaliação do risco de plumas de contaminação de combustiveis contendo etanol.- Seminário de Avaliação de risco ambiental Bases para estratégias de remediação de áreas contaminadas - 1999

26. Courseil, $\mathrm{HX}$ and Alvarez, PJJ - Natural Bioremediation Perspective for BTX-Contamineted Groundwater in Brazil Revista Microbiolol.,1996 -27 (1) 43-50

27. CRC - Handbook of CHEMISTRY and PHYSICS $-84^{\text {th }}$ Edition - Editor David R. Lide - 2003-2004 CRC Press Inc www.hbcpnetbase.com

28. Damato, M. - Estudo da Influencia do nível de Tratamento de Efluentes de Refinarias de Petróleo na sua Toxicidade, Empregando Diferentes Espécies Indicadoras. Vol I e II - Tese apresentada 'Escola Politécnica da Universidade de São 
Paulo para obtenção do título de Doutor em Engenharia. SP 1997

29. Decreto número 79.367, de 9 de março de 1977 - Dispões sobre normas e o parão de potabilidade de água, e dá outras providências. Governo Federal - 1977.

30. Djozan, $\mathrm{Dj}$ and Assadi, Y. - A new porous-Layer ActivatedCharcoal-Coated Fused Silica Fiber: Application for Determination of BTEX Compounds in Water Samples using Headspace Solid-Phase Microextration and Capillary Gas Chromatography - Chromatographia - 1997 - Vol 45- 183189.

31. Doherty, L. - Analysis of Semi-volatile Organics in Drinking Water (EPA Method 525) - Hewlett Packard - 1990

32. Doherty, L. - The Analysis of Volatile Organics Compounds in Drinking Water (EPA Method 524.2) - GC/MS Application Note - Hewlett Packard - 1991

33. Duffus, JH.-"Glossary for chemists of terms used in toxicology", Pure Appl. Chem. 65 (9), 2003-2122 (1993). IUPAC.

34. Eenaeme, van C, Bienfait, JM, Lambot, O, Pondant, A, Studies on Ghosting, na Important Source of Error In the Quantitative Estimation of Free Volatile Fatty Acid by GCL. - I. Occurrence of Ghosting and Factors Influencing It. Jour. Chrom. Sci Vol. 12 July 1974 - 398-403. 
35. Eenaeme, van C, Bienfait, JM, Lambot, O, Pondant, A, Studies on Ghosting, na Important Source of Error In the Quantitative Estimation of Free Volatile Fatty Acid by GCL.II. Effect of Sample VFA Concentration on Ghosting Magnitude and Effectiveness of Remedies to Limit Ghosting. Jour. Chrom. Sci Vol. 12 July 1974 - 403-410.

36. Eisert, R. and Levsen, K. - Solid-Phase microextration coupled gas chromatography: a new method for the analysis in water. Journal of chromatography A.733 - 1996 - 143-157.

37. Elke, K; Jermann, E; Begerow, J. and Dunemann, L. Determination of benzene, toluene, ethylbenzene and xylenes in indoor air at environmental levels using microextration and high-resolution gas chromatography-flame ionization detection. Journal of Chromatography A 826 (1998) 191-200.

38. $\quad$ EPA - Final Best Demonstrated Available Technology (BDAT) Background document for Universal Standards, Volume B: Universal Standards for no wastewater forms of listed hazardous wastes - 1994b. http://www.epa.gov/

39. EPA - Environmental Protection Agency Drinking water regulations and health advisories. EPA 822-R-96-001. Washington: United States Environmental $P$ agency office water, 1996. http://www.epa.gov/

40. EPA - Environmental Protection Agency National ambient volatile organic compounds (VOC's) data base update. Atmospheric sciences research laboratory. EPA-600/3-88/010 (a): Research Park, NC: EPA, 1988. http://www.epa.gov/ 
41. EPA - Environmental Protection Agency. USEPA Office of Drinking Water health advisories. Reviews of environmental contamination and toxicology, 1988, 106:189-203. http://www.epa.gov/

42. EPA - Environmental Protection Agency. USEPA Office of Drinking Water. Benzene. Health advisories. Washington, DC 1987 http://www.epa.gov/

43. EPA - U.S. Environmental Protection Agency - Polution Prevention Act 1990 - Green Chemistry Webpag - 2004 http://www.epa.gov/gcc/whats gc.html

44. EPA - United States - Environmental Protection Agency U.S.EPA - Children's Environmental Health Yearbook - June 1998.

Http://www.epa.gov/

45. EPA - United States - Environmental Protection Agency U.S.EPA - Guidelines for Carcinogen Risk Assessment EPA630/R-00/04 - September 1986.

Http://www.epa.gov/

46. EPA - United States - Environmental Protection Agency U.S.EPA - Health assessment document for toluene: final report. Washington: EPA, 1983. http://www.epa.gov/

47. EPA - United States - Environmental Protection Agency U.S.EPA - Proposed Guideline for Carcinogen Risk Assessment - EPA/600/R-92/003C -April 1996. http://www.epa.gov/ 
48. EPA - United States - Environmental Protection Agency U.S.EPA - Risk Assessment and Risk Management in Regulatory Decision - Final Report V.2 1997. http://www.epa.gov/

49. EPA - United States Environmental Protection Agency Sample preservation pp.xv-xx. In Methods for Chemical Analysis of Water and Wastes - EPA-600/4-79-020 - 1983. http://www.epa.gov/

50. EPA - United States Environmental Protection Agency. Residue Chemistry Test Guidelines - Residue Analytical Method - OPPTS 860.130 - EPA 712-C-96-174, 1996http://www.epa.gov/

51. EPA - United States Environmental Protection Agency. Effluents guidelines division. Development document for effluent limitations guidelines and standards for the paint formulating. Point source category. Washigton, EPA, 1979. http://www.epa.gov/

52. EPA-(BDAT) - Best Demonstrate Available Technology Background document for Paint Production Wastes - K-179 and K-180.- December 22, 2000. http://www.epa.gov/

53. EPA-(BDAT) - Final Best Demonstrated Available Technology Background document for Universal Standards, Volume A: Universal Standards for no wastewater forms of listed hazardous wastes - 1994a. http://www.epa.gov/

54. $\quad$ EPA-IRIS - U.S. Environmental Protection Agency's Integrated Risk Information system (IRIS) on etil benzeno (100-41-4) - 
http://www.epa.gov/ngispgm3/iris on the substance File List as of March 15, 2000.

55. EPA-IRIS - U.S. Environmental Protection Agency's Integrated Risk Information system (IRIS) on Toluene (108-88-3) http://www.epa.gov/ngispgm3/iris on the substance File List as of March 15, 2000.

56. Ethyl Benzene data bank - Hazard Substance Databank (HSDB), data base of the National Library of Medicine's, TOXNET system. Http://toxnet.nIm.nih.gov - May - 2002.

57. EU - European Commission (2000) - Guidance document on residue analytical methods. Document SANCO/825/2000 Revision 6.

58. EU - European Commission (2000) - Quality control procedures for pesticide residue analysis. Document SANCO/31/03/2000.

59. EU - European Commission (2000) - Residues: Guidance for generating and reporting methods of analysis in support of preregistration data requirements for Annex II (part A, Section 4) and Annex III (part A, Section 5) of Directive 91/414. Document SANCO/3029/1999. Http://www.epa.gov/

60. Feldman, RG. - Occupational and Environmental Neurotoxicology, 1999, Lippincott-Raven-New York - pag.4.

61. Garicano, EA, Vaes, WHJ, Hermes, JLM. - Validation of Negligible Depletion Solid-Phase Microextration as a Tool to Determinine Tissue/Blood Partion Coefficients for Semivolatile 
and Nonvolatile Organic Chemicals. Tox. And Appl. Pharmacology 166, 138-144 (2000)

62. Górecki, T and Pawliszyn, J. - Solid-Phase Microextration/ Isothermal GC for Rapid Analysis of Complex Organic Samples - J. High Resol. Chromatography - March 1995 ; Vol. $18-161-166$.

63. Górecki, T, Pawliszyn, J. - Sample Introduction Approaches for Solid Phase MicroExtration-Rapid GC - Anal. Chem. 67: 32653274 (1995)

64. Grbic-Galic D, Henry, SM, Godsy, EM, Edwards E, and Mayer KP. - Organic Substances and Sediments in Water - LEWIS PUBLISHERS - Robert Baker - Editor - Vol. 3 - Biological Cap. 15 pag.239-267- 1991

65. Grote, C, Pawliszyn - Solid Phase Microextration for the Analysis of human Breath- Anal. Chem. 69 587-596 (1997).

66. Guidance document on residue analytical methods Directorate General Health and Consumer Protection European Commission - Sanco/825/00 ver.6 - 2000

67. Gulensoy, N, Alvares, PJJ. - Diversity and correlation of specific aromatic hydrocarbon biodegradation capabilities. Biodegradation 10: 331-340, 1999.

68. Hajimiraglia H, Ewers U, Brockhous A, Biettger A. - Levels of benzene and other volatiles aromatic compounds in the blood of non-smokers and smokers. In Arch Occup Environ Health 1989;61:513-518. 
69. Harmon, A, Marsli, R Dekker, R. - Technique for analyzing Food Aroma, New York pp. 96-100 (1997)

70. Herber, RFM. - Fundamental Toxicology for Chemists Chapter 2- pag 17-41 - Edited by John H. Duffus ans Howard G.J. Worth -1996 - The royal Society of Chemist - Information Service.

71. Hespanhol, I. - Potencial de Reuso de Água no Brasil Agricultura, Industria, Municípios, Recarga de Aqüiferos Revista Brasileira de Recursos Hidricos, Vol. 7, n4 Out/Dez 2002, 75-95.

72. Hirata, R. - Conceitos e panorama de vulnerabilidade de solo e das águas subterrâneas.- Seminário de Avaliação de risco ambiental Bases para estratégias de remediação de áreas contaminadas - 1999

73. Hirata, R, Ferreira, L. - Poluição das águas subterrâneas por indústrias: um método de avaliação de risco. In crong. Hidrogeológico Latino-americano, 1, Mérida, Venezuela, 1992, anais, Mérida, Alshud

74. Holderrith, J, Tóth, T. and Váradi, A. - Minimizing the time for Gas Chromatographic Analysis Search for Optimal Operational Parameters by a Simplex Method. Jour. Of Chrom.119, (1976) 215-222.

75. Horan, NJ. - Biological Wastewater Treatment Systems Theory and Operation - John Wiley \& Sons - 1990 second edition. 
76. IARC - International Agency for Research on Cancer. Some industrial chemical and dyestuffs. Lion, 1982:93-148 (IARC Monographs on the Evaluation of the carcinogenic Risk of Chemical to Humans, volume 29)

77. Illing HPA. - Fundamental Toxicology for Chemistry - Chapter 5 and 6- Editated by Jonh H. Duffus and Howard G.J. Worth The Royal Socity of Chemistry-Information Service-1996-UK.

78. IRIS - Glossary of Risk Assessment Related Terms, U.S. Environmental Protection Agency, Washington, DC (1992). IRIS online http://www.epa.gov/ngispgm3/iris/

79. James, K, Stack, M. - The Determination of Volatile Organic Compouds in soils Using SPME with Gas ChomatographyMass Spectrometry - J. Hight Res. Chomatogr. 19: 515-519 (1996)

80. Keith, LH. et al - Identification and Analysis of Organic Pollutants in Water. Keith L.H. ed, 1976. 329-373

81. Keith, LH, Crummett, W, Deegan Jr, John, Libby RA, Taylor JK, and Wentler G. - Principles of Environmental Analysis Committee of environmental improvement - American Chemical Society - 1983.

82. Kobayashi H, Rittmann BE. - Microbial removal of hazardous organic compounds - Environ. Sci. Technol. Vol. 16, (2000)

83. Langenfeld, J, Hawthorne, S, Miller, D. - Optimizing Split/Splitless Injection Port Parameters for SPME. J. Chromatogr. A740 (1): 139-145 (1996) 
84. Lei número 997 de 31 de maio de 1976 - Dispóe sobre o controle da poluição do Meio Ambiente. - Governo do Estado de São Paulo. 1976

85. Leite F. - Validação em Análise Química - $3^{a}$ edição - Editora átomo - 1998.

86. Louch, D, Motlagh, S, Pawliszyn J. - Dynamics of organic compound extraction from water using liquid-coated defused silica fibers - Anal. Chem. 64 - 1187-1199-1992

87. MacGillevra, B. - Headspace SPME vs. Purge \& Trap for the Determination of Substituted Benzenes in Water. J. Chromatogr. Sci. 32: 317-322 (1994)

88. Manahan, SE. - Fundamentals of Environmental Chemistry Boca Raton [Fla.] - Lewis Publishers, xv, 844p - 1993

89. Matisová E, Sedlákova J, Simon P, Welsch, T. - Solid Phase Microextration of volatile from water using open cap vials Chromatographia 49 9/10, may 1999.

90. Menéndez, JCF, Sánches MLF, Uria, JES, Martinez, EF, Sanz-Medel, A. - Static headspace, solid-phase microextration and headspace solid-phase microextration for BTEX determination in aqueous samples by gas chromatography Anal. Chimica ACTA 415 (2000) 9-20.

91. Middleton FM, Rosen AA, Burstschell RH. - Taste and odor research tool as for water utilities. Journal of the American Water works association, 1958, 50:21-28. 
92. Morita, DM. - Tratabilidade de Águas Residuárias Contendo Poluentes perigosos - Estudo de Caso_ Vol. I, II, III - Tese apresentada à Escola Politécnica da Unicversidade de São Paulo para obtenção do título de Doutor em Engenharia. SP 1993.

93. Mota, MFPS, Rosa, R. - Apostila do curso de Noções básicas de cromatografia em fase gasosa - Instituto de Pesquisas Tecnológicas do Estado de São Paulo. Maio 1987.

94. Motlagh, S, Pawliszyn, J. - On-Line Monitoring of Flowing Samples Using SPME-GC - Anal. Chim. Acta 284:265 (1993)

95.

NRC - National Research Council - Environmental Epidimiology: dimensions of the problem: exposure assessment. Washington: Nacional Academy Press, 1991.

96. NDDH- North Dakota Department of Health - Division of Waste Management - Guideline: Procedures for headspece analysis of gasoline contaminated soils - revision 03/01 - 2001 http://www.health.state.nd.us

97. Ødegaard, H. - Chemical Floc Formation in Wastewater Tretment - NA Introduction - Prog. Wat. Tech. 1979, Suppl. 1 pp 103-110.

98. Patty F. (ed) Industrial Hygiene and Toxicology; Volume II; Toxicology 2nd ed. New York; Intercience Publishers, 1963. 1221.

99. Pawliszyn. J. - SPME - Solid Phase Microextration - Edited by Janusz Pawliszyn - VCH, New York, 247pp (1997). 
100. Poisindex - Toxicological databank - Micromedex, Inc. Denver, Colorado, 1974-1998.

101. Popp, P, Paschke, A. - Efficiency of direct SPM from Water: Comparison of different fiber types including a new C8-coating - Chromatographia, 49(11/12) 686-690-1999.

102. Portaria número 1469, de 29 de dezembro de 2000 Estabelece os procedimentos e responsabilidades relativos ao controle e vigilância da qualidade da água para consumo humano e seu padrão de potabilidade, e dá outras providências. - Ministério da Saúde - Agência Nacional de Vigilåncia Sanitária -2000.

103. Pottler, D, Pawliszyn, J. - Detection of substituted Benzenes in Water at the $\mathrm{pg} / \mathrm{mL}$ level using Solid Phase Microextration and GC-Ion Trap Mass Spectrometer - J. Chromatograph. 625:247-255(1992).

104. Prenafeta-Boldú, FX, Luykx, DMA, Vervoort, J. and Bont, JAM - Fungal metabolism of toluene: monitoring of fluorinates analogs by $19 \mathrm{~F}$ nuclear magnetic resonance spectroscopy. Appl. Environ. Microbiol.Vol 67:1030-1034 - 2001.

105. Prenafeta-Boldú, FX, Vervoort, J, Grotenhuis, JTC, and Groenestinjn, JW. - Substrate Interactions during the Biodegradation of Benzene, Toluene, Ethylbenzene, and Xylene (BETX) Hydrocarbons by the Fungus Cladophialophora sp. Strain T1. - Appl. Environ. Microbiol. Vol. 68: 6 - 26602665 - 2002

106. Radtke, DB. - Processing of Water Samples - Sample 
Preservation - U.S. Geological Survey - TWRI book 9 - pag. 89-94. May - 1999

107. Reinhard, M. - Trace organic removal by advanced waste treatment - Journal of the Environ. Engin. Division, v. 105, $n^{\circ}$ 4, pag. 675-694, Aug. 1979

108. Resolução CONAMA número 20 , de 18 julho de 1986. Dispões sobre a classificação das águas doces, salobras e salinas, em todo o Território Nacional, bem como determina os padrões de lançamento. Conselho Nacional do Meio Ambiente - CONAMA - 1986.

109. Rula AD, Alvarez-cohen $L$, Temperature effects and substrate interactions during the aerobic biotransformation of BTEX mixtures by toluene-enriched consortia and Rhodococcus rhodochrous. Biotech. And Bioeng. Vol. 62, issue 5, 526-536, 1999.

110. Sarna, LP, Webster GRB, Fischer, MRF, Rajan, RS. - Analysis of the petroleum components benzene, toluene, ethyl benzene and xylenes in water by commercially avaiable solid-phase microextration and carbon-layer open tubular capillary column gas chromatography - J. Chromatogr. A. 677, 201-205, (1994).

111. Schwarzenbach, RP, Gschwend, PM, and Imboden, D. Environmental Organic Chemistry- 1993 - Jonhn Wiley \& Sons, inc.

112. Shaw IC, Chadwick J. - Principles of Environmental Toxicology - Taylor and Francis Ltd. 1998 - pag 98-141. 
113. Shirey RE. - Optimization of extraction for Low-MolecularWeight analytes using SPME - Journal of Chromatography Science, Vol. 38, March 2000, 109-116.

114. Soniassy RD - Environmental Analysis - Instrumental Techniques - Hewlett-Packard - analytical Products - 1990.

115. Sowinski, J, Baughman, G. - Groundwater VOC sample Preservation Policy - Colorado Department of Public Healht and Environment - State of Colorado - June 1998.

116. Stephen, $L M$, and Christopher A. - Response Surface Evaluation and Optimization in Gas Chomatography. Journal of Chromatography Sci, 16 (octuber 1978) 500-505.

117. Stephen, LM., and Stanley ND. - Optimization Strategies for the Development of Gas-Liquid Chomatographic Methods. Journal of Chromatography, 112 (1975) 267-285.

118. Steven, PT; Ranjan, RS, Webster, GRB. and Sarna, L. Protocol for the Analysis of High Consentrations of Benzene, Toluene, Ethyl benzene, and Xylene Isomers in Water Using Automated Solid-Phase Microextration -GC-FID. Enviromental Science \& Techology - 1996; Vol. 30; NO. 5

119. Supelco - A practical guide to quantitation with solid phase microextration - Bulletin 929 - Sigma Aldrich.Co.-2001

120. Supelco - Application 95 - Optimizing SPME: Parameters to Control to Ensure Consistent Results. - Sigma-Aldrich Co. 1997 
121. Supelco - Application note 17 - Poliacrylate Film Fiber for Solid Phase Microextration of polar semivolateles from Water. - Sigma-Aldrich Co. 1997

122. Supelco - Application note 81 - Monitor BTEX Compouds and Fuels in Water, using Solid Phase Microextration and Capillary GC - Sigma-Aldrich Co. 1995.

123. Supelco - Bulletin $901 \mathrm{~A}$ - Solid phase Microextration/Capillary GC Analysis of Drogs, Alcohols, and Organic Solvents in Biological Fluids. - Sigma-Aldrich Co. 1999

124. Supelco - Bulletin 923 - Solid Phase Microextration: Theory and Optimization of Conditions -Sigma-Aldrich Co. 1998

125. Supelco - Purge and Trap System Guide - Bulletin 916 Sigma Aldrich Co. -1997.

126. Supelco - Solid phase microextration: Theory and optimization of Conditions - Bulletin 923 - Sigma Aldrich.Co. - 1998.

127. Supelco - SPME Portable Field Sampler with $100 \square \mathrm{m}$ PDMS Fiber - Sigma-Aldrich Co. 1997

128. Supelco - Guide to solid phase extraction - Bulletin 910 Sigma Aldrich Co. - 1998.

129. Theelen, R. - Risk assessment of contaminated soils-The use of Csoil model - Seminário de Avaliação de risco ambiental Bases para estratégias de remediação de áreas contaminadas $-1999$ 
130. Toffgard, R, Gustafsson JA. - Biotransformation of organic solvents: a review. Scand J Work Environ Health, 1980:6:1-8

131. Toluene data bank - Hazard Substance Databank (HSDB), data base of the National Library of Medicine's, TOXNET system. http://toxnet.nlm.nih.gov - May - 2002

132. TOXINET - Hazardous substances Databank (HSDB), a databank of the National Library of Medicines - TOXNET system - http://toxnet.nlm.nih.gov on June 12, 2002.

133. Valor, I. and Cortada C. - Direct Solid-Phase Microextration for the Determination of BTEX in Water and Wastewater. - J. High Resol. Cromatograhy - August 1996 - Vol. $19-472-474$.

134. Varian Sample Preparation Products - Varian Inc. September $-1996$.

135. Voznaya, NF. - Chemistry of Water \& Microbiology - Mir Publishers Moscow first Edition - 1983.

136. Wallace L, Pellizzeari E, Hartwell $T$, et al. - Concentrations of 20 volatile organic Counpounds in the air and drinking water of 350 residents of New Jersey compared with concentration in their exhaled breath. J Occup Med, 1986;28:603-608.

137. Wallace L, Pellizzeari E, Hartwell T, et al. The California Team study: breath concentrations and personnel exposure to 26 volatile compounds in air and drinking water of 188 residents of Los Angeles, Antioch and Pittsburg, CA Atmos Environ 1988;22:2141-2163. 
138. WHO - World Health Organization - Guidelines for Drinking Water Quality - Volume 2 - Health criteria and other supporting information, 2nd edition. 1996 -

139. Willard, H, Merritt, L, Dean, J. - Análise Instrumental Fundação Caloustre Gulbekian - pag. 604-648. - 1979.

140. Wylie PL. - Trace analyses of volatile compounds in water using the HP 7694 Headspace sample - HP Publication Note 228-40 - Hewlett Packard Co. 1985

141. Xylene data bank - Hazard Substance Databank (HSDB), data base of the National Library of Medicine's, TOXNET system. http://toxnet.nIm.nih.gov - June - 2002

142. Yang, $X$, Peppard T, SPME of Flavor Compounds - A Comparison of Two Fiber Coating and Discussion of the Rules of Thumb for Adsorption Liq. Chrom-Gas Chrom. 13 (11): 882 886 (1995).

143. Zhang, Z, Pawliszyn J. - Headspace Solid Phase Microextration - Anal. Chem. 65, 1843-1845-1993

144. Zhang, Z, Pawliszyn J. - Quantitative Extraction Using an Internally cooled solid Phase Microextration Device. - Anal. Chem. 67, 34-43-1995.

145. Zhang, Z, Yang MJ, Pawliszyn J.-Solid Phase Microextration A solvent-Free Alternative for Sample Preparation - Anal. Chem. $66,844 A-843 A-1994$ 